\title{
Neotectonics, Kinematics, and Evolution of the Vernon, Awatere, and Cloudy Faults of the Marlborough Fault System, New Zealand
}

Timothy David Bartholomew

A thesis submitted in fulfilment for the degree of Masters of Science in Geology, Victoria University of Wellington, September 2012 


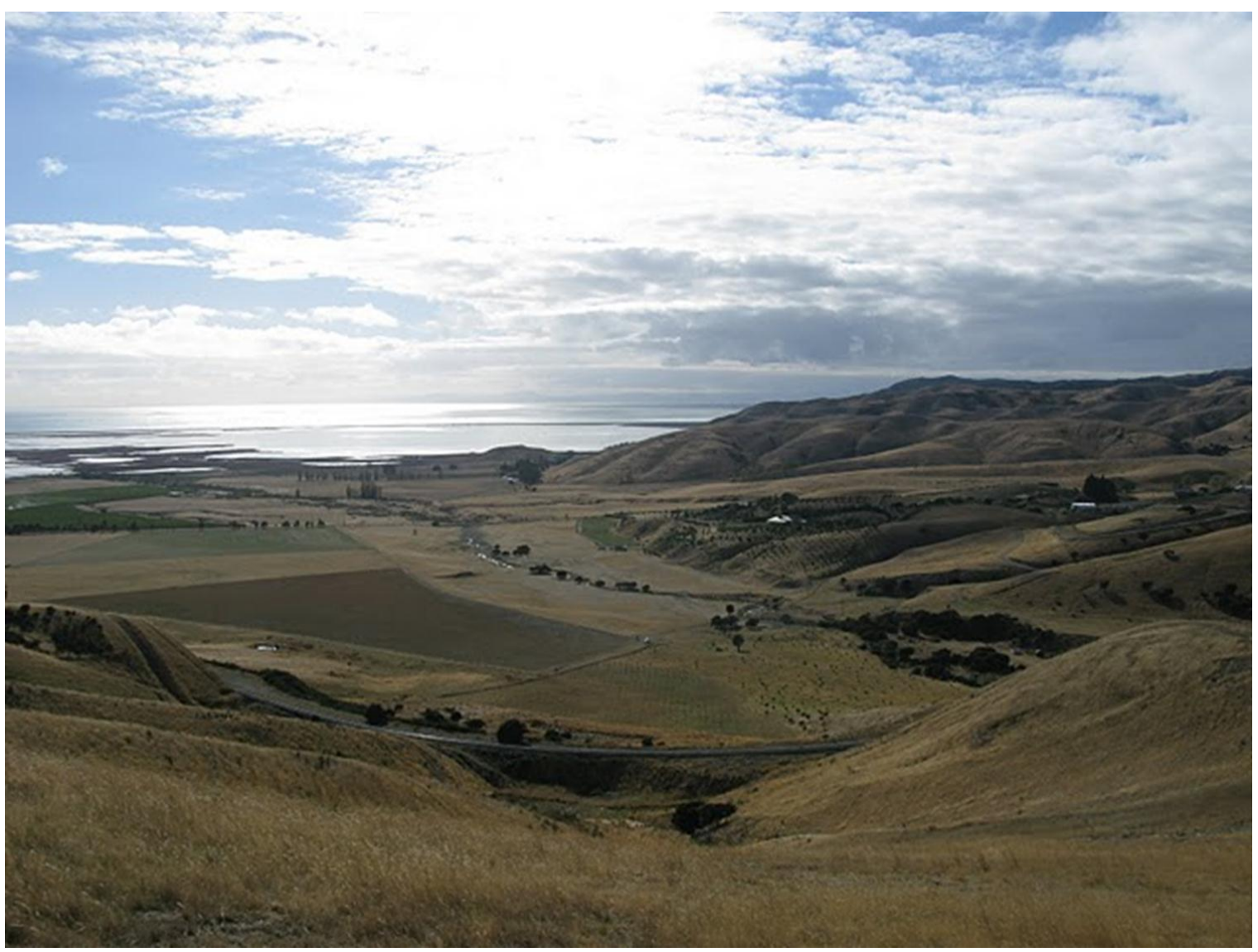

Frontispiece) Looking northeast over the dry, windy Vernon Hills and Big Lagoon. 


\section{Thesis Abstract}

The coastal Awatere, Vernon, and Cloudy faults are bent and mutually intersecting, forming a complexly deforming dextral-oblique fault network. To try to explain the kinematic, paleoseismic and evolutionary complexities of this network, I present the results of an investigation into the rates, timing, and direction of slip on the faults within the network; which bifurcate eastwards from the central Awatere fault at the northeast end of the Marlborough Fault System. Displacements of dated and nondated late Quaternary features by the three faults were measured both onshore and offshore, constraining the kinematics of the fault network. The Vernon fault oddly maintains a dextral-reverse structure although it varies over $90^{\circ}$ in strike and the Cloudy and coastal Awatere faults change from nearly pure strike slip to having a normal component eastwards. These data indicate that the fault-bounded blocks between the coastal Awatere, Vernon and Cloudy faults are rotating anticlockwise about a vertical axis relative to the block to the north of the fault system. Slip-rate data also indicate that of the $6 \pm 1 \mathrm{~mm} / \mathrm{yr}$ of slip on the central Awatere Fault, $1.1 \pm 0.6$ $\mathrm{mm} / \mathrm{yr}$ has been partitioned ENE onto the coastal Awatere Fault and $<4.9 \mathrm{~mm} / \mathrm{yr}$ has been partitioned NNE onto the Vernon Fault. A slip-rate shortage in the splays of the Vernon Fault in the Vernon Hills is caused by a combination of unsighted faults and rotation of smaller splay-bounded blocks within the Vernon Hills. Paleoseismic records on the Vernon Fault were analysed onshore in a trench and offshore on seismic lines, with the records in good agreement. 3-5 earthquakes are recognised at different sites, with the last earthquake occurring $3.3 \mathrm{ka}$ and a mean recurrence interval of 3-4 ka on 
the Vernon Fault. When combined with the paleseismic records from the Awatere and Cloudy faults I find that separate faults ruptured at similar times, suggesting a connectivity of the faults, as separate faults could mutually rupture during one earthquake or an earthquake could subsequently trigger an earthquake on a nearby fault. Finally I present the finite slip of geologic units and use these data as well as the late Quaternary slip data to describe the evolution of the fault network. I propose that the fault network at the NE end of the Awatere fault has stepped northwards into several splays, caused by clockwise rotation of the NE tips of the Marlborough faults. 


\section{Acknowledgements}

First of all, I owe my supervisor Tim Little a big thanks for helping me through this project. Without his knowledge, support, tutoring, and drive this thesis could not have been possible. Tim has helped me in the field, with the science, with my scientific writing (now vastly improved), and editing the manuscript. He has always challenged me to do my best.

I have benefitted from having two other great supervisors in the form of Kate Clark at GNS and Phil Barnes at NIWA. Kate has helped my right from the start, setting up the first field trips as well as leading the trench work. Over the last couple of years we have had many productive discussions and she has edited my manuscript, Thank you. Phil has been brilliant, teaching me how to interpret the offshore seismic data, which has been invaluable for my thesis. Thanks for the marathon discussions, editing the manuscript, and all the time you have put into me.

This thesis has benefitted from funding provided by an EQC research fund, a Victoria University TGSF tectonics grant, and a Victoria University Summer Scholarship.

Mark Henderson, Hamish McCoy, and Andrew Rae have provided fantastic technical support, helping me with RTK GPS surveying, data processing, field gear, and with GIS. Brent Alloway provided helpful advice on the analysis of tephra shards. Thanks to Ninsheng Wand and Uber Reiser for dating my OSL samples at the VUW Luminescence lab.

I would like to thank all of the people who accompanied me on my missions to Blenheim. A special thanks goes to Chris Davy, who I spent two weeks of bromance in Blenheim with, and to Gemma Wihare for helping me through the trauma of constantly losing gear in the field. Gemma also has shared an office with me and was always keen to help with things like editing and geology/non-geology related chinwags. Good on you. 
My other office mates have been wonderful as well: Ben, Megan, and Dee. Thank you for the entertainment, discussions and yummy food.

I would also like to acknowledge the support and friendship of my class mates Bella, Ramona, Georgia, Matt R, Simon, Leroy, Brook, Katy, Richard, Kolja, Kylie, Tom, Ben H, and any others I have missed. You have made it memorable!

Thanks to Mum and Dad for the support over the last 5 and a half years of university, I couldn't have done it without you.

Lastly, I would like to thank Meg for being by my side throughout. Thank you for the love and support through all the stress and absence. 


\section{Table of contents}

Title page

Frontispiece. .ii

Thesis Abstract

Acknowledgements ...............................................................................

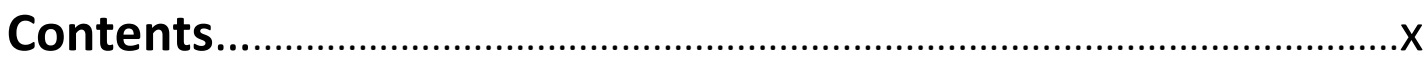

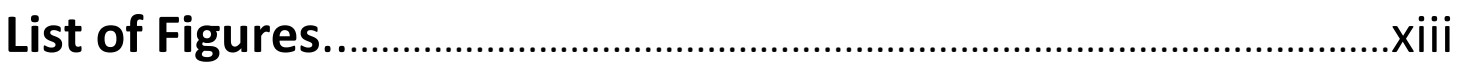

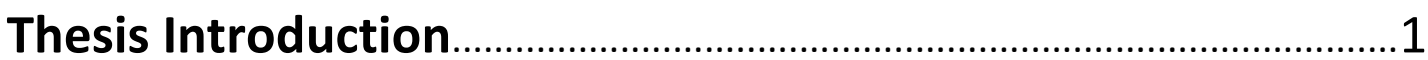

Chapter 1: Kinematics and Paleoseismicity of the active Vernon Fault, Marlborough Fault System, New Zealand: Implications for fault interactions and southern Hikurangi subduction earthquakes.

Chapter 2: Late Quaternary kinematics and late Cenozoic evolution of the coastal Awatere, Vernon, and Cloudy Faults, Marlborough Fault System, New Zealand.

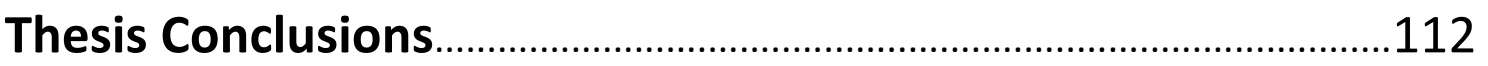

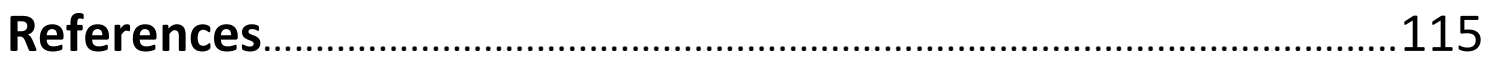

Appendix A: OSL dating techniques and data..................................121

Appendix B: RTK GPS survey techniques and data.........................124

Appendix C: Trench unit descriptions ...............................................134

Appendix D: Extra offshore paleoseismic working.........................137

Appendix E: Extra offshore seismic profiles.......................................147 
1: Kinematics and Paleoseismicity of the active Vernon Fault, Marlborough Fault System, New Zealand: Implications for fault interactions and southern Hikurangi subduction earthquakes.

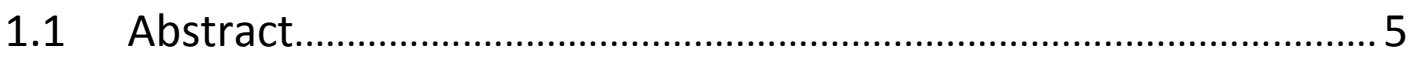

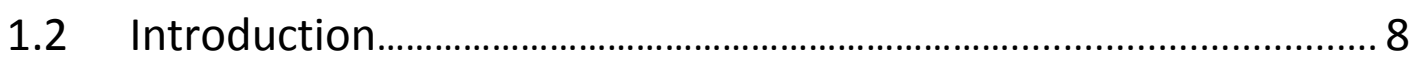

1.3 Tectonic Setting/ Previous work......................................................... 10

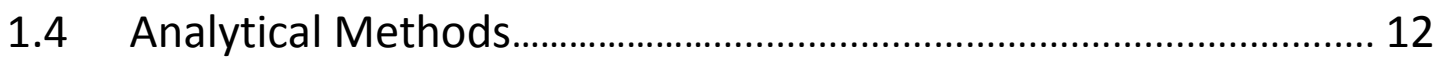

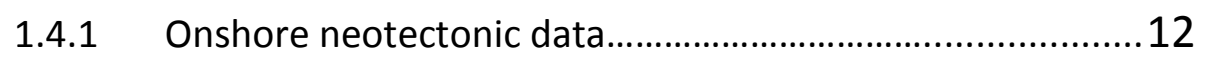

1.4.2 Offshore neotectonic data.............................................. 13

1.5 Background Stratigraphic Framework............................................. 16

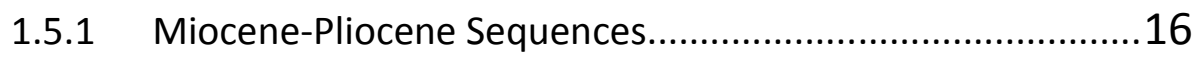

1.5.2 Sea Level Changes and late Quaternary Estaurine and Marine Sequences........................................................... 16

1.5.3 Late Quaternary River Terraces........................................19

1.6 Terrace Stratigraphy Relevant to Fault Displacement

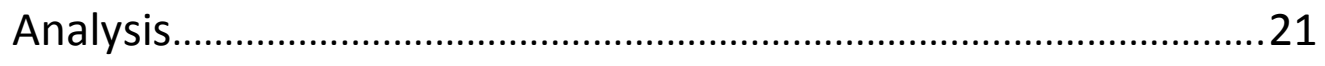

1.7 The Vernon Fault: Structure and Displacement Rate...................... 24

1.7.1 Vernon Hills Section......................................................... 24

1.7.2 Big Lagoon Section........................................................... 30

1.7.3 Wairau Basin Section......................................................... 33

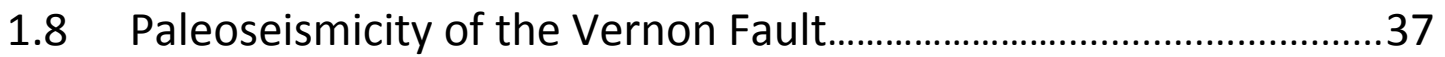

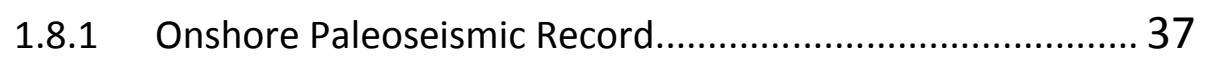

1.8.2 Offshore Paleoseismic Record...........................................43

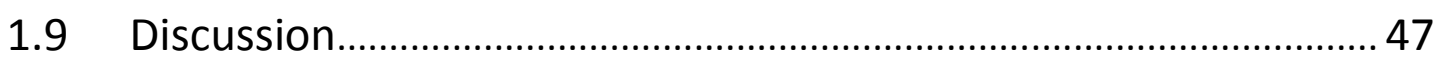

1.9.1 Slip Rates and Kinematics of the Vernon Fault...................47

1.9.2 Implications for subsidence of Big Lagoon......................... 51

1.9.3 Onshore-offshore paleoseismic correlations on the Vernon Fault: Implications for hazard and fault

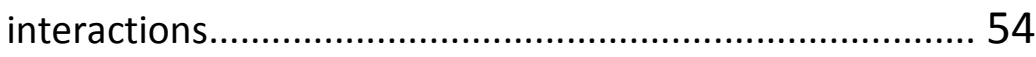


2: Late Quaternary kinematics and late Cenozoic evolution of the coastal Awatere, Vernon, Cloudy, and Cloudy Faults, Marlborough Fault System, New Zealand.

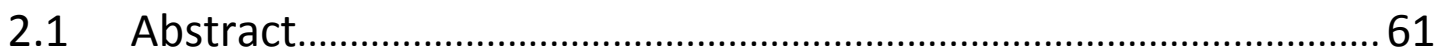

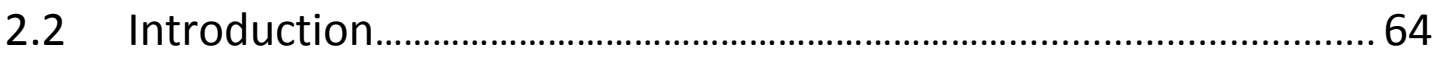

2.3 Tectonic Setting …………………………………………………………....... 67

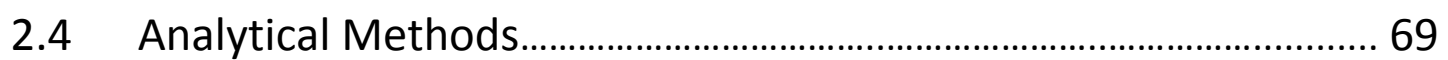

2.4.1 Onshore Neotectonic Data on the Awatere Fault................ 69

2.4.2 Offshore Neotectonic Data on the Vernon, Awatere, and Cloudy Faults...................................................................... 71

2.5 Background Stratigraphic Framework ………………………….........73

2.5.1 Miocene-Pliocene Sequences................................................... 73

2.5.2 Late Quaternary Marine Sequences......................................... 74

2.5.3 Late Quaternary River Terraces................................................. 74

2.6 Terrace Stratigraphy Relevant to Fault Displacement

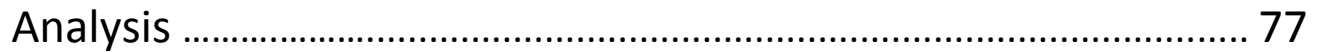

2.7 Neotectonics of the Awatere, Vernon, and Cloudy Faults.............82

2.7.1 Neotectonics of the coastal Awatere Fault.............................82

2.7.2 Neotectonics of the Vernon Fault.........................................93

2.7.3 Neotectonics of the Cloudy Fault............................................ 94

2.8 Total Slip on the Awatere, Vernon, and Cloudy Faults....................97

2.8.1 Comparison of onshore finite slip on the Vernon and Awatere Faults.

2.8.2 Finite slip on the Vernon, Cloudy, and Fuchia faults in the offshore region................................................................. 98 


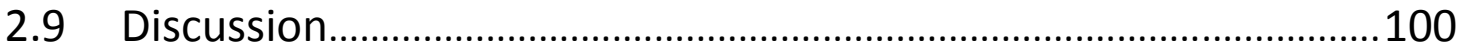

2.9.1 Rigid Block Model.................................................................... 100

2.9.2 Block Rotation Mechanisms..................................................... 104

2.9.3 Evolution of the Vernon, Awatere, and Cloudy Faults.......... 105

2.10 Conclusions 


\section{List of figures}

1: Kinematics and Paleoseismicity of the active Vernon Fault, Marlborough Fault System, New Zealand: Implications for fault interactions and southern Hikurangi subduction earthquakes.

1.01 Geologic map of the Vernon, Awatere, and Cloudy Faults and surrounding area

1.02 Maps showing neotectonic measurements on splays of the Vernon Fault.

1.03 Stratigraphic sections of late Quaternary river terrace deposits.

1.04 RTK topography maps of landforms displaced by the Dumgree splay 25

1.05 RTK topography maps of landforms displaced by splays of the Vernon Fault near Flaxey Gully.

1.06 RTK topography maps of the displacement at Homestead Stream

1.07 The DG01 multichannel seismic line and offshore vertical slip rates

1.08 Paleoseismic trench log. 38

1.09 Interpreted offshore paleoseismic boomer lines and compilation of vertical displacement-age plots.

1.10 Summary of paleoearthquakes onshore and offshore on the Vernon Fault. .46

1.11 Summary of fault slip on the Vernon, Awatere and Cloudy faults

1.12 Map of modelled coseismic subsidence during a 1 in 500 year earthquake on the Hikurangi subduction margin.

1.13 Timeline and map showing timing and location of paleoearthquakes on the Vernon, Awatere and Cloudy faults.... 55 
T1.1 Onshore neotectonic data. 23

T1.2 Offshore neotectonic data. 34

2: Late Quaternary kinematics and late Cenozoic evolution of the coastal Awatere, Vernon, Cloudy, and Cloudy Faults, Marlborough Fault System, New Zealand.

2.01 Geologic map of the Vernon, Awatere, and Cloudy Faults and surrounding area. 63

2.02 Maps showing neotectonic measurements on splays of the coastal Awatere Fault. 76

2.03 Stratigraphic sections of late Quaternary river terrace deposits. 79

2.04 RTK topography map of the displacement of Dumgree Hill .84

2.05 RTK topography maps of displaced landforms near the coast..... 86

2.06 Offshore boomer seismic lines running across splays of the Vernon and coastal Awatere faults 90

2.07 Summary of fault slip on the Vernon, Awatere and Cloudy faults.

2.08 Onshore map and offshore profile DG01 showing total displacement of the Vernon, Awatere, and Cloudy faults 96

2.09 Rigid block model reconstruction. 102

2.10 Model of fault network evolution. 106

T2.1 Onshore neotectonic data 81

T2.2 Offshore neotectonic data 89 
Appendix A: OSL dating techniques and data

A1 Water contents, radionuclide contents......................................... 123

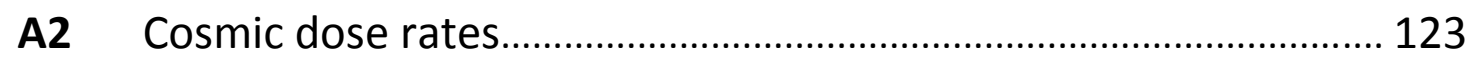

A3 a-values, dose rates, equivalent doses, and Luminescence dates

Appendix B: RTK GPS survey techniques and data

B1-15 Real-time Kinematic GPS survey data $.126-133$

Appendix C: Trench unit descriptions

C1 Trench unit descriptions $.135-136$

Appendix D: Extra offshore paleoseismic working

D1 Conceptual model for fault stratal growth [Pondard and Barnes, 2010]

D2-8 Trench unit descriptions 140-146

Appendix E: Extra offshore seismic profiles

E1-10 Extra offshore seismic profiles spanning splays of the Vernon and coastal Awatere faults. 148-157 


\section{Thesis Introduction}

The northern part of the Marlborough Fault system is a complex zone of dextral-oblique faulting, being part of a transition zone between subduction of the Hikurangi Margin to the north and transpressive continental collision to the south. Deformation of the wider northeastern part of the Marlborough System has been widely studied [Lamb, 1988; 2011; Roberts, 1992; 1995; Little and Roberts, 1998; Wallace et al., 2004; 2012] and indicate that vertical axis rotation of fault-bounded blocks is, and has been, prominent within this transition zone since the Neogene. The Marlborough faults are seismogenic, accumulating stress and rupturing at intervals on the order of 100 to 1000 years [Little and Grapes, 1997; Benson et al., 2001; Zachariasen et al., 2006; Barnes and Pondard, 2010; Pondard and Barnes, 2010].

In this thesis I focus on the northeast end of the Awatere Fault, one of the four major Marlborough faults, where it bifurcates into a network of several faults; the coastal Awatere, Vernon and Cloudy faults. Measuring late Quaternary slip on these three faults can lead to interpretations of the kinematics of these faults and can contribute to our understanding of the kinematics of the northern Marlborough Fault System. Measuring the paleoseismicity on the Vernon Fault can lead to an assessment of the seismic hazard presented by the fault and can contribute to our knowledge of how earthquakes have been distributed throughout the fault network. Finally, determining finite slip data on these faults will lead to an assessment on how the fault network at the eastern end of the Awatere Fault has evolved since its initation and can contribute to our knowledge of the evolution of the wider Marlborough Fault System since the Neogene. 
This thesis contains two chapters, each written as scientific papers. Each chapter is self-contained and certain aspects of the two chapters overlap; hence there is repetition of some introductory material, datasets, and figures.

Chapter 1 is entitled 'Late Quaternary Slip on the Vernon Fault' and it investigates the late Quaternary kinematics and paleoseismicity of the Vernon fault. To determine the kinematics of the Vernon Fault onshore, I measure the displacement of 43 late Quaternary landforms, some which are age constrained using OSL dating, and assess fault geometry at 4 fault exposures. Offshore, I measure the vertical fault displacements on late Quaternary reflectors with modelled ages and assess fault dip using 14 seismic profiles. Onshore, a paleoseismic trench was analysed to help determine a paleoseismic record of the Vernon Fault, mapping displaced deposits on the trench walls that are age constrained by OSL and radiocarbon dating. Offshore, the boomer seismic data was used to further our understanding of the paleoseismic record of the Vernon Fault, identifying fault growth strata with ages of $<20 \mathrm{ka}$.

Contributions to chapter 1 include Timothy Little as the main supervisor, providing guidance in the field and during writing as well as editing the manuscript. Kate Clark is lead author of the GNS report [Clark et al. 2011b] that has been referenced for the paleoseismic trench and two dated displacements on the Vernon Fault that have been used. She also helped with supervision, fieldwork, and editing. Timothy Little and Russ Van Dissen also assisted in the logging and interpretation of the trench in the field [Clark et al. 2011b]. Phil Barnes supervised the paleoseismicity and neotectonic work offshore, providing guidance, advice, and editing of the manuscript. I also use two boomer seismic lines interpreted in Pondard and Barnes [2010] in our analysis of the paleoseismicity of the Vernon Fault offshore. 
Chapter 2 is entitled 'Late Quaternary kinematics and late Cenozoic evolution of the coastal Awatere, Vernon, and Cloudy Faults, Marlborough Fault System, New Zealand'. To determine the kinematics of the fault network I use neotectonic techniques on the Awatere and Cloudy faults and combine these data with neotectonic data on the Vernon and Cloudy faults from Chapter 1 and Pondard and Barnes [2010]. Onshore, I measure the displacement of 49 late Quaternary landforms, some which are age constrained by OSL dating. Offshore, I measure the displacement of late Quaternary reflectors with modelled ages and assess the dip of the fault on 16 seismic profiles. From these data I reconstruct a rigid block model by back-slipping the three faults, proposing a model of slip and deformation within the fault network. Finite slip data on the three faults was also estimated onshore and offshore by measuring the strike- or dip- slip displacement of Miocene to Pleistocene units. These data were compared to late Quaternary slip rate data and used to constrain relative fault ages of the Vernon, coastal Awatere, and Cloudy faults; ultimately used to estimate the evolution of the fault network.

Contributions to chapter 2 include supervision in the field, advice and editing of the manuscript by Tim Little. Phil Barnes assisted and supervised the offshore observations. Kate Clark provided guidance in the field.

The Appendices present extra data that cannot be presented within the two chapters, they include:
A. Optically Stimulated Luminescence Dating Methods and Data
B. RTK GPS Methods and Data
C. Descriptions of units within the paleoseismic trench.
D. Boomer seismic lines used to analyse the paleoseismicity of the Vernon Fault as well as displacement time graphs showing fault growth.

E. The boomer seismic profiles I used to assess the neotectonics of the faults offshore. 
Chapter 1: Kinematics and paleoseismology of the active Vernon Fault, Marlborough Fault System, New Zealand: Implications for fault interactions and southern Hikurangi subduction earthquakes. 


\subsection{Abstract}

The $\sim 40 \mathrm{~km}$ long Vernon Fault, part of the Marlborough Fault System of New Zealand, characterised by dextral strike-slip with a subordinate reverse component, and exhibits complex variations in strike of $>90^{\circ}$. I determine the kinematics and paleoearthquake history of the fault by integrating late Quaternary neotectonic and paleoseismic data from both its onshore and offshore sections. From onshore fieldwork, aerial photographs, and offshore seismic reflection data, I identify three geometric sections of the fault: (1) the NNE-striking Vernon Hills section which branches from the Awatere Fault; (2) the NE-striking Big Lagoon section which extends $\sim 9 \mathrm{~km}$ offshore and converges with the coastal Awatere Fault and offshore Cloudy Fault; and (3) the entirely submarine, E-Wstriking Wairau Basin section. Optically Stimulated Luminescence dating and tephrochronology have been used to date fluvial terrace deposits associated with displaced landforms, establish slip rates, and assign ages to paleoseismic events identified in a trench across the fault. The seismic reflection data were used to constrain fault structure, vertical displacement rates along strike, and enhance previous paleoearthquake records identified from post-seismic fault growth sequences in the postglacial $(<20 \mathrm{ka})$ sediments. The dextral slip rate increases from $<1.5 \mathrm{~mm} / \mathrm{yr}$ on multiple splays through the Vernon Hills to $<4.9 \mathrm{~mm} / \mathrm{yr}$ south of Big Lagoon, however the dextral rate is not known offshore. The dip-slip rate is generally low $<0.15 \mathrm{~mm} / \mathrm{yr}$, but increases locally to almost $1 \mathrm{~mm} / \mathrm{yr}$ beneath the inner continental shelf where there is structurally complex overlap with the Cloudy and coastal Awatere faults, and it may be higher also in the Vernon Hills section. Inferred net slip vectors on the fault are spatially variable and suggest fault motion parallel to the Pacific-Australian plate motion vector is partially distributed off the fault. The onshore and offshore paleoseismic records are in good agreement, with 3-5 events recognised at different sites, a mean recurrence interval of 3-4 ka, and an elapsed time since the last event of $3.3 \mathrm{ka}$. Paleoearthquakes on the Vernon Fault occur in close temporal association with earthquakes on the Awatere and Cloudy faults, indicating the possibility of mutual rupturing or fault interactions and close-in-time earthquake triggering. 
Mutual rupturing in some events would be consistent with inferred or measured large single event displacements. Earthquakes on the Vernon Fault adjacent to Big Lagoon are likely responsible for $>25 \%$ of the total Holocene subsidence of the lagoon. The remaining subsidence may result from southern Hikurangi subduction interface earthquakes. 
a)
$174^{\circ} \mathrm{E}$
$174.1^{\circ} \mathrm{E}$

$174.2^{\circ} \mathrm{E}$

$174.3^{\circ} \mathrm{E}$

$174.4^{\circ} \mathrm{E}$

$41.5^{\circ} \mathrm{S}$

Explanation

Beach/Estaurine deposits

$N \square$ Inactive Beach ridge ( 2 ka)

Quaternary alluvial gravel

Pliocene alluvial gravel

Hillersden Formation \& Wairau Conglom.

Pliocene marine rocks

Upton Formation (Miocene)

Torlesse Terrane (Late Jurassic)

$$
\text { Fault }
$$

19y Strike/dip of bedding

* + Syncline/Anticline

$20 \mathrm{~m}$ Bathymetry

- TAN0510

Boomer seismic line

L1 and number (Bold are presented in Fig 9)

$\star$ Ends of Vernon fault sections

$41.6^{\circ} \mathrm{S}$
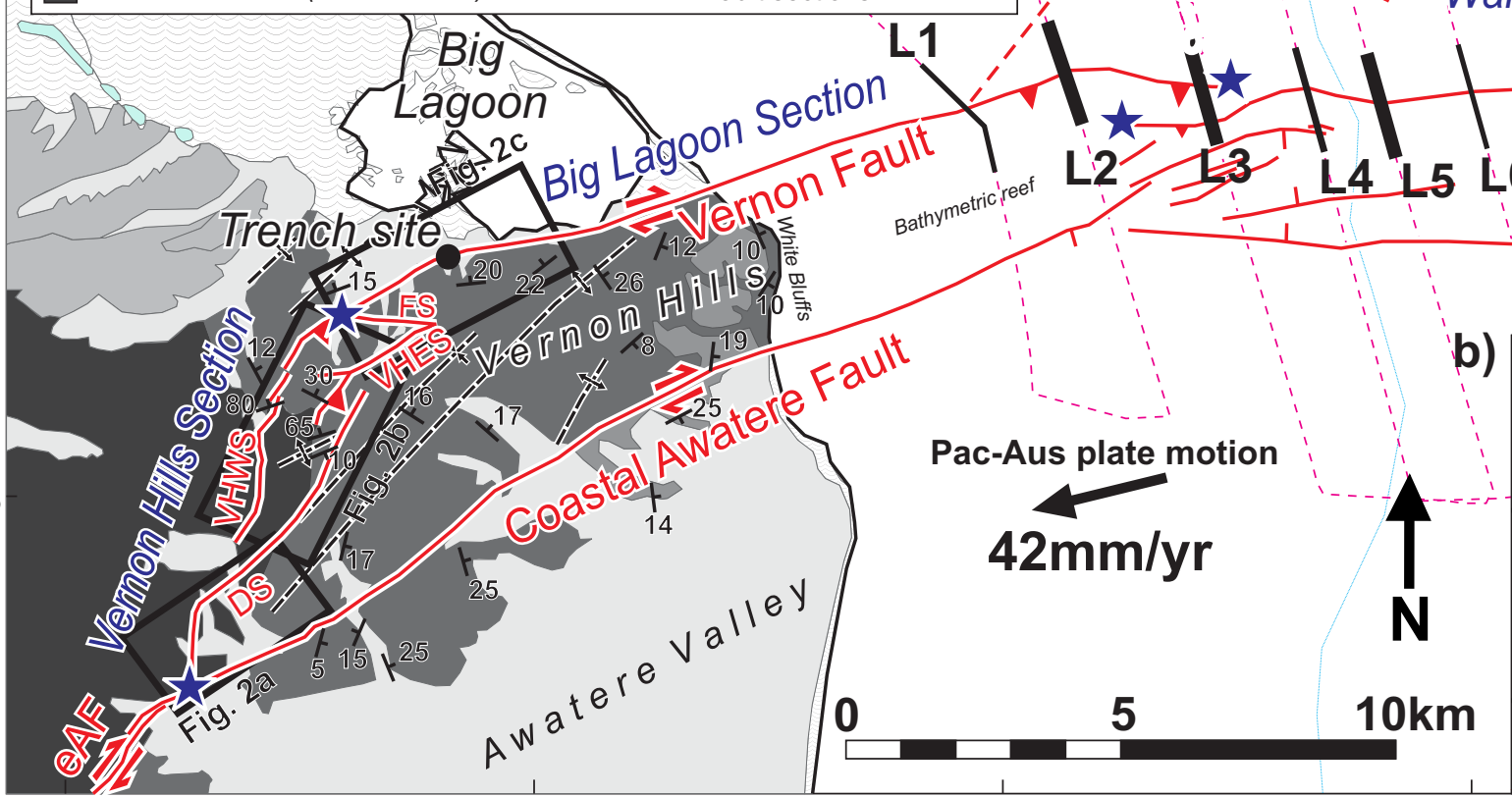

Wairà-Básin Section
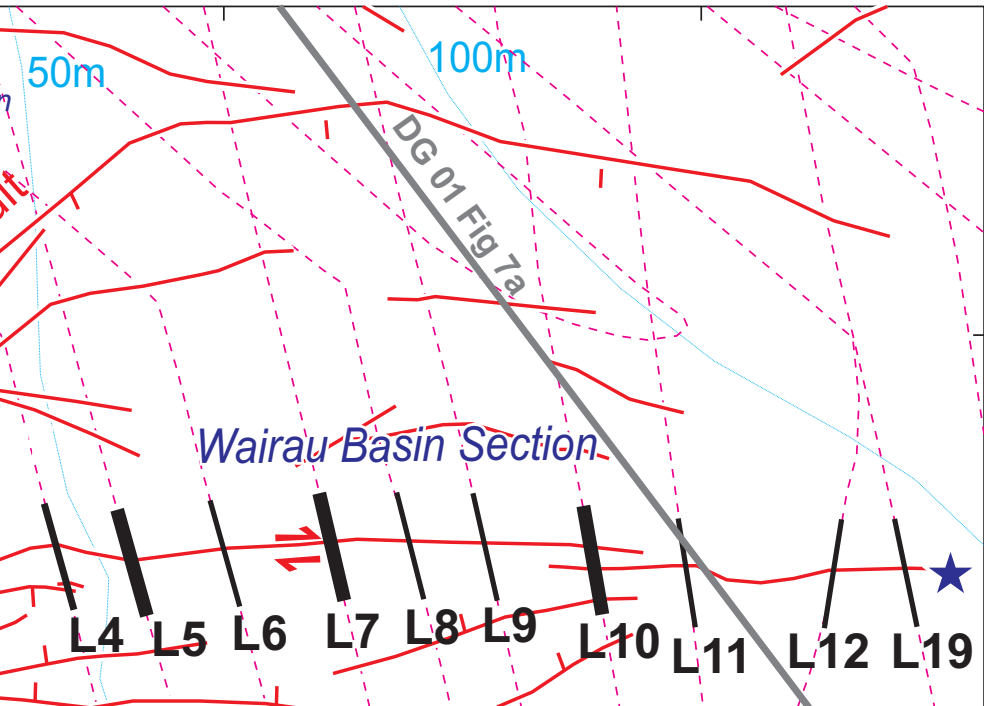

AUs $50 \mathrm{~km}$

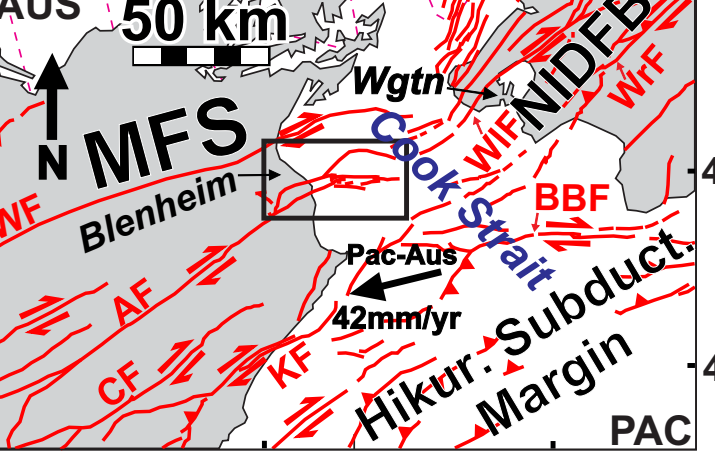

Figure 1 a) Geologic map of the Vernon-Awatere Fault system showing active faults, structure, bathymetry, and onshore geologic units. Offshore faults are largely from Pondard and Barnes, [2010]. The voyage tracks from the RV Tangoroa voyage TAN0510 are the pink lines [Barnes and Pondard 2010; Pondard and Barnes, 2010]. The black lines show the profiles used for offshore earthquake analysis. The Pacific-Australian relative plate motion vector is from Beavan et al., [2002]. eAF= eastern Awatere Fault, DS= Dumgree splay, VHWS=Vernon Hills Western splay, VHES= Vernon Hills Eastern splay, FS= Flaxey Splay b) A map showing the Marlborough Fault System (MFS), North Island Dextral Fault Belt (NIDFB) and the Hikurangi Margin. The faults are in red. The black box shows the area of Fig 1a. AUS=Australian Plate, PAC= Pacific Plate. WF =Wairau fault, $A F=$ Awatere fault, $C F=$ Clarence Fault, $K F=$ Kekerengu Fault, $B B F=B o o$ Boo Fault, WrF= Wairarapa Fault, WIF= Wellington Fault, Wgtn= Wellington. 


\subsection{Introduction}

A fault bend on a strike-slip fault either connects sub-parallel strike-slip segments or dissipates into unfaulted rock across a zone of distributed deformation. Localised transpression or transtension at fault bends can be accommodated by oblique faulting, by partitioned strike- and dip-slip faulting, by vertical axis rotation of fault bounded blocks, or by distributed deformation [Cowgill, 2004; Cunningham and Mann, 2007]. Where strike-slip is partitioned between multiple fault splays, there can be stress variations between splays as a result of coseismic loading or unloading following an earthquake [Sibson, 1994]. Fault bends may act as earthquake propagation barriers [Sibson, 1985; Barka \& Kadinsky-Cade, 1988], or if they extend down to seismic depths, may provide a nucleation site for large ( $M>7$ ) earthquakes [Bayarshayan et al., 1996; Harris et al., 2002].

The Vernon Fault in the Marlborough Fault System of New Zealand (Fig. 1 inset) has a dramatically varying strike $\left(\sim 90^{\circ}\right)$ and lies within an overall transpressional tectonic regime. These changes in fault strike are expected to cause complex lateral variations in deformation. The southwest end of the fault appears to be a restraining bend that transfers slip from the eastern Awatere Fault, north eastwards. In this paper I describe the Vernon Fault structure, determine kinematic behaviour and paleoearthquake history, and discuss interactions with the nearby Awatere and Cloudy faults. I map fault traces, displacements of landforms, and fault exposures, and document late Quaternary slip rates. Offshore seismic profiles, including high-resolution boomer and multichannel seismic data [Pondard and Barnes, 2010] (Fig. 1) are reinterpreted to constrain fault geometry and vertical slip rate.

It has been proposed that tectonic subsidence of Big Lagoon, located on the downthrown block of the Vernon Fault, may record coseismic subsidence during subduction earthquakes on the Hikurangi 
subduction thrust east of Cook Strait (Fig. 1 inset), [Clark et al., 2011b]. In order to test this hypothesis, the vertical deformation associated with the Vernon Fault must be considered. A more generic objective of this study is to improve understanding of how Pacific-Australian plate motion is being accommodated on a time timescale of $\sim 30 \mathrm{ka}$.

Paleoseismic records have previously been determined onshore at several sites on the Awatere Fault [Benson et al., 2001; Mason and Little; 2006], and offshore on the Cloudy and Vernon faults [Pondard and Barnes, 2010]. In this study of the Vernon Fault I present new paleoseismic data from a trench site onshore [Clark et al., 2011b], and develop enhanced offshore records by advancing the high-resolution analysis of the displacement history along the strike of the fault in Cook Strait (Fig. 1). These data enable us to (1) compare results from conventional paleoseismic trenching methodologies onshore with the offshore seismic reflection methodologies developed by Barnes and Pondard [2010], and (2) help resolve temporal patterns of earthquakes on the Vernon, Awatere, and Cloudy faults, which have implications for earthquake hazard and possible fault interactions in regions of transition from subduction to continental transpression [Pondard and Barnes, 2010; Robinson et al., 2011]. 


\subsection{Tectonic Setting/Previous Work}

The Marlborough Fault System (MFS) lies in the transition zone between subduction of oceanic Pacific Plate to the northeast (Hikurangi Margin) and oblique continental collision to the southwest (Fig. 1). The Hikurangi subduction margin terminates beneath the southern end of the MFS [Reyners et al., 1998]. A conspicuous discontinuity in fault trends and linkage exists across Cook Strait between the NE striking North Island Dextral Fault Belt (NIDFB) and the NE striking MFS [Pondard and Barnes, 2010] (Fig. 1 inset). The MFS today accommodates most of the Pacific-Australian relative plate motion through transpressive dextral-reverse faulting in the continental crust [Wallace and Beavan, 2004; Wallace et al., 2012]. Major active structures within the MFS include the strike-slip Wairau, Awatere, Clarence and Hope faults, with late Quaternary dextral rates of about 4, 6, 4 and 20 mm/yr respectively [Van Dissen and Yeats, 1991; Little et al., 1998; Benson et al., 2001, Nicol and Van Dissen, 2002; Langridge et al. 2003; Mason and Little, 2006].

The $\sim 40 \mathrm{~km}$ long Vernon Fault branches north from the eastern Awatere Fault, and bends eastwards near Big Lagoon, running into Cook Strait (Fig. 1). Our knowledge of the dextral-slip rate on the Vernon Fault largely stems from slip rate observations on the Awatere Fault. The eastern Awatere Fault accommodates $6 \pm 1 \mathrm{~mm} / \mathrm{yr}$ of dextral slip approaching its junction with the Vernon Fault (Fig. 1), [Benson, 2000]. East of this junction a slip rate of $\sim 1 \mathrm{~mm} / \mathrm{yr}$ has been measured on the coastal Awatere Fault based on two offset river terraces near the coast [Little et al., 1998; Chapter 2, this thesis]. This implies that up to $5 \mathrm{~mm} / \mathrm{yr}$ of slip may be partitioned northeast onto the Vernon Fault. Displacement of geomorphic landforms at two sites on the Vernon Fault, in the Vernon Hills and adjacent to Big Lagoon lead to slip rate estimates of $<2 \mathrm{~mm} / \mathrm{yr}$ [Benson, 2000]. These slip rates account for only $50 \%$ of the slip thought to be transferred from the eastern Awatere Fault, leaving a slip rate deficit of $\sim 3 \mathrm{~mm} / \mathrm{yr}$ to be accounted for [Little et al., 1998]. These preliminary 
interpretations also suggest that the strike-slip component is dominant in the more northerly striking splays in the Vernon Hills, where the fault has the geometry of a restraining bend relative to the Awatere Fault. The only other previous slip rates estimates on the Vernon Fault were measurements of dip slip rates of late Quaternary reflectors offshore using seismic profiles [Pondard and Barnes, 2010]. These authors demonstrated that the fault is steeply dipping $\left(>70^{\circ}\right)$ to the south, and is downthrown to the north, indicating a reverse component of displacement. They interpreted that the offshore vertical displacement rate on the fault decreases from potentially $1-2 \mathrm{~mm} / \mathrm{yr}$ near the coast to $0.1-0.2 \mathrm{~mm} / \mathrm{yr}$ further east, south of the Cloudy Fault.

Paleoseismic data has shown that repeated $M>7$ earthquakes have ruptured the Wairau, Awatere, Vernon and Cloudy faults during the last 10-20 ka [Benson et al., 2001; Zachariasen et al., 2006; Barnes and Pondard, 2010; Pondard and Barnes, 2010]. Historically, the M 7.5 Marlborough earthquake ruptured the Awatere Fault in 1848 [Grapes and Downes, 1998; Mason et al., 2006], whilst the paleoseismic data from onshore trenching indicates that the Awatere Fault has ruptured 6 times since $\sim 8.4 \mathrm{ka}$, with a mean recurrence interval of $\sim 1.4 \mathrm{ka}$ [Benson et al., 2001]. Pondard and Barnes [2010] interpreted that the Cloudy and Vernon faults have mean recurrence intervals of $\sim 2.7$ ka and $3.1 \mathrm{ka}$, and last ruptured $\sim 1.8 \mathrm{ka}$ and $3.2 \mathrm{ka}$, respectively. 


\subsection{Analytical Methods}

\subsubsection{Onshore neotectonic data}

I mapped the active traces of the Vernon Fault using aerial photographs ortho-rectified to topographic maps (NZTopo50-BR29) and direct field observations, and measured 32 displacements of landforms (Table 1). Five of these were measured using Real-Time Kinematic (RTK) GPS derived topographic maps, thirteen were measured with a tape measure (including small offsets in deep bush cover), and eighteen were estimated through scaling from vertical aerial photographs. Three estimates of fault throw was achieved by laser levelling of a fault scarp. Four fault exposures in outcrop were examined. Displacements of two ridge flanks, two channels and a terrace surface were surveyed using RTK GPS to construct Digital Elevation Models (DEMs) and a contour map. The DEMs were constructed using a krigging interpolation [Olivier, 1990] of measured points at 0.25-4 m sample intervals with the Trimble R-8 RTK GPS unit. To constrain the strike-slip fault displacement of the landforms, once continuous terrace edges, valleys and ridges were projected linearly to the fault from each side, and errors assigned using the technique of error triangles [Little et al., 2010]. The throw of the fault was quantified by measuring the height of the scarp from a profile perpendicular to the fault constructed with the DEM.

To establish displacement rates on the Vernon Fault (Table 1), river terraces were dated by the presence of volcanic tephra or by Optically Stimulated Luminescence (OSL) dating [Murray and Wintle, 2000] of fluvial deposits and/or loess coverbeds. The tephrochronological constraints were provided by identifying glass shards related to the Kawakawa Tephra $(25.3 \pm 0.1 \mathrm{ka}$, [Vandergoes et al., 2011]), the only tephra younger than 190 ka present in the Marlborough region [Eden, 1989; Pillans 1991; Eden and Hammond, 2003], in either the loess deposits or in underlying lenses of fluvial 
silt or sand (Fig. 3). OSL ages were also measured from the silt deposits described above. Dating loess coverbeds constrain the minimum age of terrace abandonment, whereas dating silt or sand lenses within the gravels constrain a maximum age of the timing of fluvial abandonment. Sand, silt and gravel units exposed in the walls of a $13 \mathrm{~m}$ long by $3 \mathrm{~m}$ deep trench excavated across the Vernon Fault were mapped and sampled for dating [Clark et al. 2011b]. Four charcoal samples were radiocarbon dated at the Rafter Radiocarbon Laboratory, Lower Hutt and the ages were calibrated using OxCal v. 4.1 [Bronk Ramsey, 2001].

\subsubsection{Offshore neotectonic data}

I used high-resolution seismic reflection data reported by Barnes and Pondard [2010] and Pondard and Barnes, [2010]. These profiles, including 13 sections across the offshore Vernon Fault, spaced at 1.5-2.0 km and with penetration of $\sim 100-200 \mathrm{~m}$, were obtained using a 500-2000 Hz Applied Acoustic CSP-300 boomer system. The maximum resolution for the dataset is $\sim 40 \mathrm{~cm}$, the smallest fault vertical displacement detectable. In this study I modified a previous structural interpretation of the Vernon Fault reported by Pondard and Barnes [2010], and adopted their seismic stratigraphic framework to analyse vertical displacements of $<20 \mathrm{ka}$. The age of the diachronous ( $20-7 \mathrm{ka})$ post last glacial erosional surface (PGS2/1) along the strike of the fault was estimated at each profile location using the method outlined in Lamarche et al. [2006]. Pondard and Barnes [2010] estimated the age of five regional stratigraphic horizons across the Wairau Basin by assuming constant sedimentation rates above the PGS2/1 at 6 sites along Line 8 (Fig. 1), with individual site errors of $\pm 40 \%$. The ages of the five reflectors (at $95 \%$ confidence), calculated as the mean age of the reflector from the 6 sites, were estimated to be $2.7 \pm 0.6 \mathrm{ka}, 6.2 \pm 1.1 \mathrm{ka}, 8.4 \pm 1.6 \mathrm{ka}, 10.3 \pm 2.1 \mathrm{ka}$, and 14.0 $\pm 3.8 \mathrm{ka}$. In this study I expanded the stratigraphic work of Pondard and Barnes [2010] by widening 
the correlation of these reflectors across all profiles of the Vernon Fault, and evaluating vertical displacements in detail along the strike of the fault. The dip of the fault $100-200 \mathrm{~m}$ beneath the seafloor was estimated from boomer seismic lines assuming a velocity of $1600 \mathrm{~m} / \mathrm{s}$. An error in dip was assigned to encompass uncertainty in velocity $(\sim 10 \%)$ and reflector terminations at the fault, resulting from large (32X) vertical exaggeration on displayed sections. The dip was also estimated to about 5-6 km depth using the multichannel seismic section DG01 (Fig. 1) [Pondard and Barnes, 2010], by converting the time section to depth with the following interval velocities: (1) 0-1 s twt, 2$3 \mathrm{~km} / \mathrm{s}, 2) 1-2 \mathrm{~s} \mathrm{twt}, 3-3.5 \mathrm{~km} / \mathrm{s}$, and (3) $2-3 \mathrm{~s} \mathrm{twt}, 4-4.5 \mathrm{~km} / \mathrm{s}$.

I measured the vertical displacements of each of the five regional reflectors and where confident in its identification, the PGS2/1 erosion surface, to evaluate the variability in vertical displacement rate along the strike of the fault. The local vertical separation (throw) and the longer wavelength ( 1000 m) off-fault drag folding were measured to constrain the vertical rates (Table 2). The local throw estimate, derived by subtracting the hanging wall (up-thrown) depth from the foot wall (downthrown) depth, is similar to those which might be measured in the field onshore, whilst the longer wavelength deformation is the total structural elevation change across the fault, and was estimated by projecting matching reflectors to the fault from up to $1 \mathrm{~km}$ on both sides of the fault. I enhance the submarine paleoearthquake record of the Vernon Fault reported by Pondard and Barnes [2010], through wider, detailed along-strike analysis of the post-glacial $(<18 \mathrm{ka})$ vertical displacement history. The method is fully explained in Barnes and Pondard [2010], and is summarised here. First, the vertical displacement of every post-glacial seismic reflector in each boomer profile was measured, and reflector ages were inferred by assuming constant sedimentation rate between the five regional reflectors. The results were plotted as displacement-time curves, which have sloping sections reflecting increasing throw with increasing stratigraphic depth in growth intervals, and constant displacement with increasing stratigraphic depth in uniformly-thick sequences (Appendix 
D1). The growth intervals, interpreted as post-seismic, were created as a result of sediment deposition preferentially on the downthrown block, whereas intervening uniformily-thick sequences were deposited following complete burial of the fault scarp. Scarp-forming earthquakes are identified at the base of the growth sequences, and have age errors assigned as $\pm 30 \%$. The Vernon Fault is ideal for application of this methodology because the long-term sedimentation rate exceeds the vertical separation rate, and seafloor displacements are sufficient to resolve growth sequences [Barnes and Pondard, 2010]. 


\subsection{Background Stratigraphic Framework}

\subsubsection{Miocene-Pliocene Sequences}

Late Miocene and early Pliocene marine deposits outcrop in the Vernon Hills between the Vernon and coastal Awatere faults. Here, about $600 \mathrm{~m}$ of late Miocene Upton Formation unconformably overlies the Jurassic Torlesse Terrane basement [Little and Jones, 1998], (Fig. 1). The Upton Formation is chiefly a marine conglomerate, interbedded with turbiditic sandstone and mudstone, and at White Bluffs is overlain unconformably by an early Pliocene marine sequence $(<150 \mathrm{~m}$ thick) of interbedded conglomerate and mudstone (Fig. 1). The present elevation of these late Miocene to early Pliocene units between the Vernon and Awatere faults reflects the inversion and uplift of the basin in which they were deposited, contemporaneously with deposition of the Pliocene Hillersden Gravels [Little and Jones, 1998; Begg and Johnston, 2000]. The longer-term tectonic evolution of this basin is beyond the scope of this paper.

\subsubsection{Sea-level Changes, and Late Quaternary Estuarine and Marine Sequences}

Marine and estuarine sediments deposited during the Holocene in Big Lagoon have been affected by changes in base and sea levels. During the Holocene, eustatic sealevel rose to $\sim+0.5-1.0 \mathrm{~m}$ above mean sea level (AMSL) by 7.5 ka where it remained for until 2 ka [Clement et al., 2008], leaving a relict beach ridge on the southwestern margin of Big Lagoon [Clark et al., 2011a], (Fig. 1). After this, absolute sea level dropped to -0.5 m AMSL by 0.5 ka before rising to its current position [Clement et al., 2008]. Immediately north of the Vernon Fault, Big Lagoon was a subtidal bay at $\sim 7$ ka. It later filled with mud to form a shallow intertidal bay by 4.5-3.5 ka, and more recently a semi-closed 
lagoon as a result of the formation of the Wairau gravel bar at the coast [Hayward et al., 2010], (Fig. 1). Cores show that the shallow marine and estuarine sediments younger than 6 ka in Big Lagoon have subsided tectonically at an average rate of $\sim 0.55 \mathrm{~mm} / \mathrm{yr}$, but present data do not constrain whether the subsidence was gradual or coseismic [Clark et al, 2011a].

Offshore beneath the continental shelf the Wairau Basin contains Quaternary shallow marine and alluvial sediments, deposited during sea-level cycles, unconformably overlying Miocene and Pliocene strata [Pondard and Barnes, 2010]. During Late Quaternary glacial periods, alluvial gravels prograded onto the shelf to lowstand shorelines $\sim 120 \mathrm{~m}$ below current sea level. During deglacial and interglacial periods transgressive and highstand sediments accumulated on diachronous erosional ravinement surfaces [Pondard and Barnes, 2010]. Since the Last Glacial Maximum (LGM 20 ka) up to $45 \mathrm{~m}$ of marine transgressive and Holocene sediments were deposited on the post last-Glacial surface (PGS2/1) in the Wairau Basin, which is inferred to be $\sim 18 \mathrm{ka}$ at the outer shelf and $\sim 7 \mathrm{ka}$ close to shore [Pondard and Barnes, 2010]. Subsidence rates since 140 ka have been estimated to vary from 0.3 to $2.5 \mathrm{~mm} / \mathrm{yr}$ across the basin.

Figure 2) Maps showing active traces of the Vernon Fault, late Quaternary terraces, locations of neotectonic slip measurements, and locations of stratigraphic logs. The Stafford Creek fan surface (SCf) and the Flaxey Gully fan surface are labelled on each map. Also shown are photographs taken at the locations and directions presented on the map. SH 1= State Highway 1. The extents of these maps are shown in Fig. 1. 


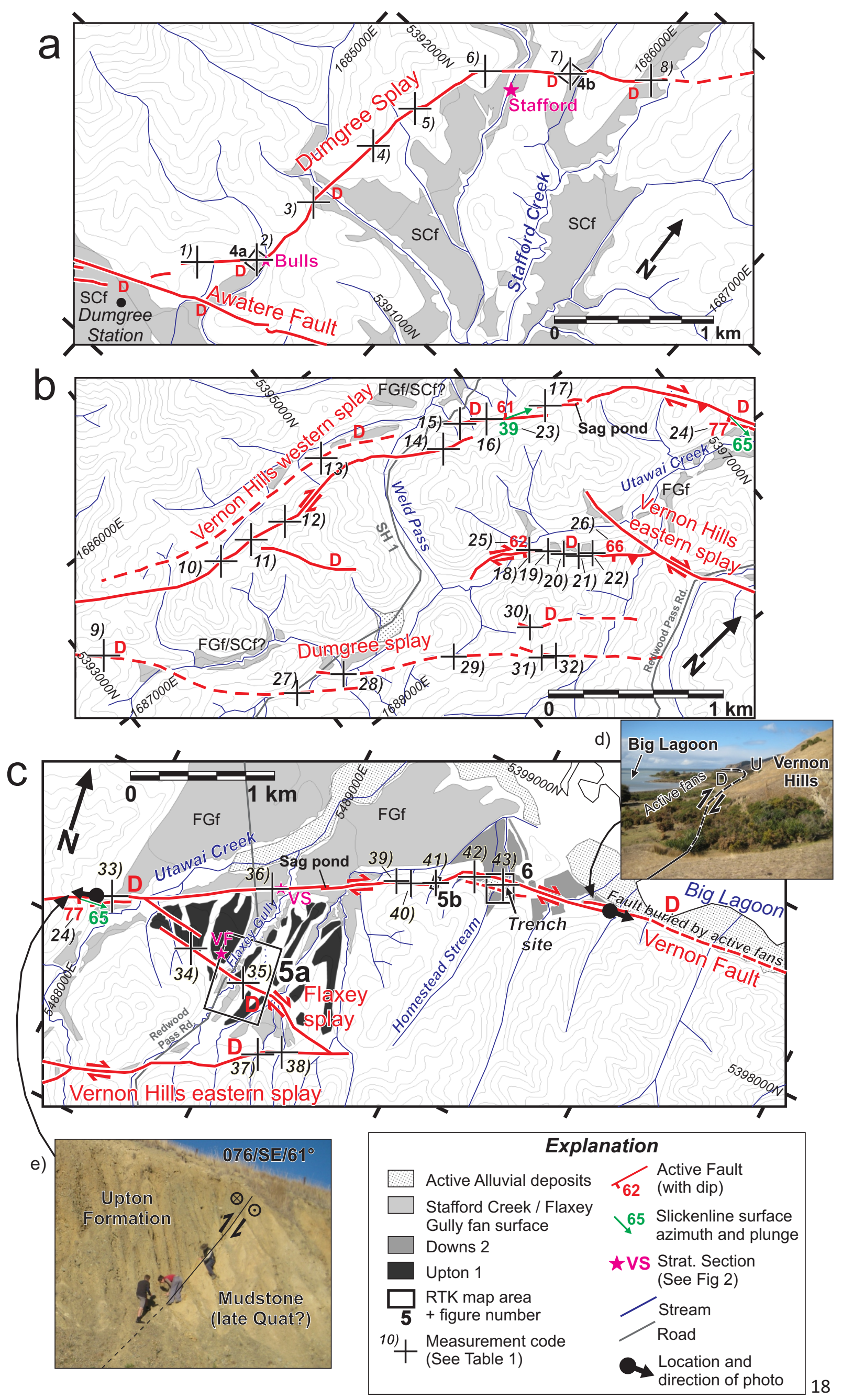




\subsubsection{Late Quaternary River Terraces}

During the late Quaternary, streams in northeast Marlborough deposited broad gravel floodplains on incised straths cut into bedrock. Repeated incision and aggradation of the floodplains during glacial-interglacial cycles and progressive uplift has produced flights of river terraces. Terrace aggradation may also have coincided with sea level rise and increased rainfall [Eden, 1989; Pillans, 1991; McCalpin, 1992; Townsend, 2001]. Aoelian loess deposits draping the alluvial gravels are inferred to have accumulated during subsequent glacial periods characterised by de-vegetation, stronger winds and increased erosion [Eden, 1989; Pillans, 1991; Townsend, 2001]. The terrace stratigraphy of the lower Awatere Valley has been well documented and dated [Eden, 1989; Benson, 2000; Townsend, 2001], a situation that helps with correlation of terraces in the nearby Stafford Creek area (a tributary to the Awatere River) and on the northern side of the Vernon Hills. 
a) Stafford

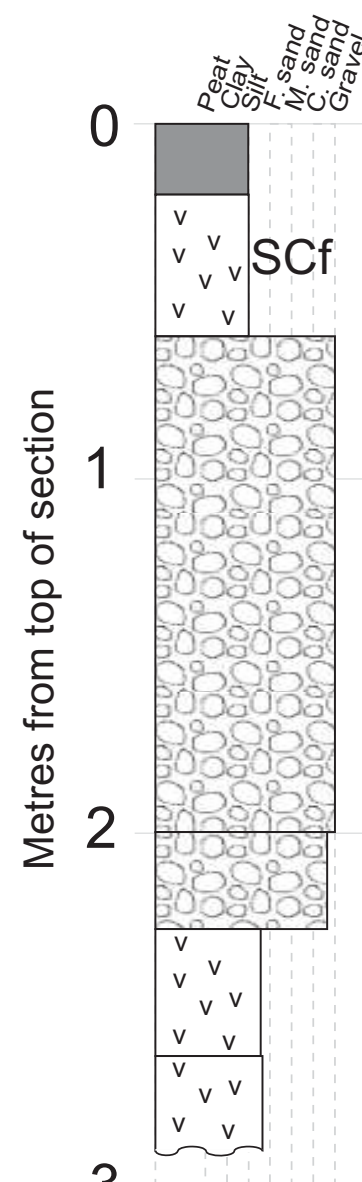

b) Dumgree

Topsoil- brown grey silt

Silt- Tan brown, massive,

diam. Disseminated

KawakawaTephra shards

KawakawaTephr
throughout.

Gravels- clast supported, sorted, clasts $0.5-5 \mathrm{~cm}$ diam.

\section{Gravels- clast supported,}

angular, imbricated, well

indurated, clasts $\sim 2 \mathrm{~mm}$ diam.

Silt- yellow brown grey,

massive, scattered pebbles.

Silt- blue grey brown, massive. c) VS

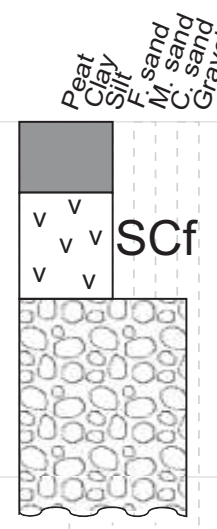

Topsoil-black brown silt

Silt- light yellow brown, massive bebles, some sily sand at Diseminat Kawakawa shards throughout.

Gravel- clast supported, silty matrix, clasts bigger and mor abundant downwards, angularsubangular, $1-10 \mathrm{~cm}$ diam.

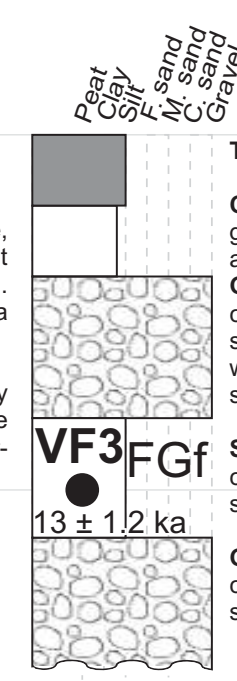

$\frac{0}{\sqrt{0}}$

Topsoil-medium brown grey silt

Clayey Silt- yellow brown w some gravel clasts- well rounded to sub-

Gravel- light yellow grey, stiff, roundedwith clay-silt alternating supported-gravelly silty clay.

Silt- Yellow grey, some grey silty clay, pebbles-sand $<5 \mathrm{~mm}$ diam. scattered throughout

Gravel- Medium orange-brown clast supported, well roundedsubangular

\section{d) VF}

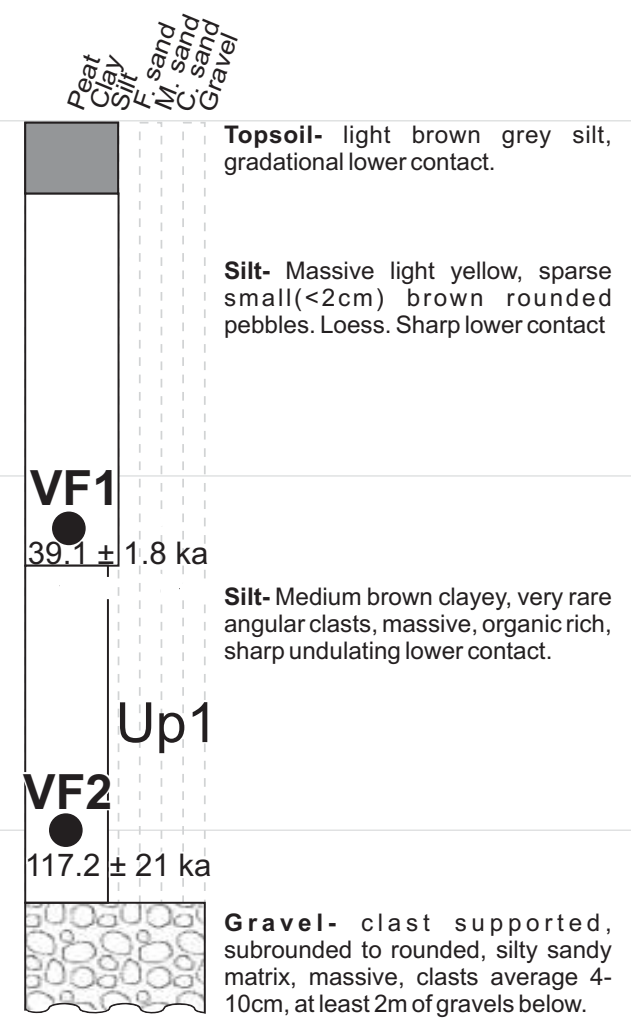

Figure 3) Stratigraphic sections of the late Quaternary river deposits and cover beds located in Fig. 2. The Stafford and Dumgree sections log the Stafford Creek fan deposits (SCf), the VS section logs the Flaxey Gully fan deposits (FGf), and the VF section logs the Upton 1 terrace deposits (Up1). VF1, 2, and 3 


\subsection{Terrace Stratigraphy Relevant to Fault Displacement Analysis}

The dating of four fluvial terraces is critical to constrain the Vernon Fault displacement rates and paleoearthquake history. Terrace remnants displaced by the Vernon Fault near Flaxey Gully (Fig. 2c) have been correlated to the 120 ka old Upton 1 (Up1) terrace [Eden, 1989; Townsend, 2001] based on an OSL age of $117.2 \pm 10.9 \mathrm{ka}$ in the loess cover sequence (sample VF, Fig. $3 \mathrm{~d}$ ). The Upton 1 terrace aggraded during the penultimate glacial maximum 120 ka [Townsend, 2001], equivalent to marine oxygen isotope stage MIS 5 [Pillans, 1991]. The terrace remnants have rounded edges, form ridges (compared to the younger LGM related terraces), are deeply ( $20 \mathrm{~m})$ incised at Flaxey Gully (Fig. 5a), and probably originated as an alluvial fan shedding from Utawai Gorge to the west.

An alluvial terrace displaced by the Vernon Fault at site 6, $1 \mathrm{~km} \mathrm{SW}$ of Big Lagoon (Fig. 2c) has been correlated to the $30 \pm 5$ ka Downs 2 (Do2) terrace [Eden, 1989; Little et al., 1998; Chapter 2, this thesis) based on an OSL age of $31 \pm 3.2$ ka (Fig. 8) from a loess cover sequence. The terrace fans northwestward from Homestead stream (Fig. 2c) and may be onlapped by the younger more a wide-spread alluvial fan (Flaxey Gully fan surface) to the northwest but the intersection between the two terraces is hard to distinguish (Fig. 2c). At Stafford Creek the Vernon Fault displaces a fan surface sourced from local tributaries in the Vernon Hills (Fig. 2a), and is referred to here as the Stafford Creek fan surface (SCf). Benson [2000] correlated this fan to the Nina Brook fan (NBf). Although I have not dated the SCf surface directly using OSL, I correlate it to the NBf based on tracing the NBf surface from Nina Brook, dissection of the surface, the geomorphology of the fan, and tephrochronology of the deposits. The NBf surface can nearly be traced uninterrupted from Nina Brook to Stafford Creek using aerial photos. Like the NBf, the SCf has sharp edges, little dissection, is incised by active streams and narrow younger terraces and onlaps bedrock ridges. At 
Nina Brook, 4 km SE of Stafford Creek, the Kawakawa Tephra has been found in a silt lens near the top of the NBf gravels [Little et al., 1998; Benson, 2000]. Similarly, at the Stafford stratigraphic section (Fig. 3a) a package of silt within the SCf gravels contains shards of the tephra. I also correlate the fan exposed in the Dumgree section to the SCf based on similar surface geomorphology and the similarity of the coverbed and the gravel units exposed. Chapter 2 [this thesis] states that the SCf could be younger than the NBf and correlate it to the NBf tentatively as I do. Benson [2001] dated the NBf using radiocarbon, obtaining an age of $21 \pm 1$ ka for abandonment of the fan.

A widespread surface fanning northeast from Utawai Creek and Flaxey Gully north of the Vernon Fault is referred to here as the Flaxey Gully fan surface (FGf) (Fig. 2c). The FGf has similar surface geomorphology to the SCf, with sharp edges, little dissection, and being cut by active streams. OSL sample 'VF3' was taken from the loess coverbed of the FGf in the VS stratigraphic section (Fig. 3c) and yielded an age of $13 \pm 1.2 \mathrm{ka}$. Hence the fluvial abandonment of the FGf occurred before $13 \pm$ $1.2 \mathrm{ka}$. Based on these data, the FGf should correlate to an early Holocene aggradation, abandoned as sea level rose. 


\begin{tabular}{|c|c|c|c|c|c|c|c|c|c|c|c|c|c|c|c|c|}
\hline Site & Easting $^{1}$ & Northing ${ }^{1}$ & Splay & $\begin{array}{c}\text { Dextral } \\
\text { disp. (m) }\end{array}$ & $\begin{array}{l}\text { Dip slip } \\
\text { disp. (m) }\end{array}$ & $\begin{array}{l}\mathrm{D} / \mathrm{T} \\
\text { side }\end{array}$ & Feat. & Method & $\begin{array}{l}\text { Feat. } \\
\text { dated }\end{array}$ & Age (ka) & $\begin{array}{l}\text { Strike-slip } \\
\text { rate } \\
(\mathrm{mm} / \mathrm{yr})\end{array}$ & $\begin{array}{c}\text { Dip-slip rate } \\
(\mathrm{mm} / \mathrm{yr})\end{array}$ & $\mathrm{H} / \mathrm{V}$ ratio & Strike/dip & $\begin{array}{l}\text { Slick. } \\
\text { Rake } \\
(\text { rhr) }\end{array}$ & $\begin{array}{c}\text { Fault } \\
\text { net } \\
\text { slip } \\
\text { azi. } \\
\end{array}$ \\
\hline 1 & 1685152 & 5390558 & Dumgree & $9 \pm 3 \mathrm{~m}$ & & $\mathrm{SE}$ & $\mathrm{r}$ & tape measure & & & & & & $\sim 042$ & & \\
\hline 3 & 1685368 & 5391134 & Dumgree & & $<4 \pm 1$ & E & ts & RTK (Append) & $\mathrm{scf}^{3}$ & $>21 \pm 3$ & & $<0.19 \pm 0.04$ & & $\sim 002$ & & \\
\hline 4 & 1685380 & 5391491 & Dumgree & $65 \pm 15$ & & E & $\mathrm{r}$ & aerial photog. & & & & & & $\sim 002$ & & \\
\hline 5 & 1685404 & 5391747 & Dumgree & $70 \pm 15$ & & E & r & aerial photog. & & & & & & $\sim 010$ & & \\
\hline 7 & 1685800 & 5392307 & Dumgree & $11 \pm 2$ & $1 \pm 0.3$ & $\mathrm{SE}$ & rf & RTK (Fig. 4b) & $\mathrm{scf}^{3}$ & $>21 \pm 3$ & $<0.52 \pm 0.1$ & $<0.05 \pm 0.02$ & $10.9 \pm 4.6$ & $\sim 050$ & & $\sim 230^{\circ}$ \\
\hline 8 & 1686080 & 5392554 & Dumgree & & $0.8 \pm 0.2$ & $\mathrm{SE}$ & ts & Scarp profile & $\mathrm{scf}^{3}$ & $>21 \pm 3$ & & $<0.04 \pm 0.02$ & & $\sim 050$ & & \\
\hline 9 & 1686570 & 5393110 & Dumgree & $22 \pm 5$ & $<10 \pm 5$ & w & $\mathrm{r}$ & tape measure & & & & & $>2.2 \pm 1.6$ & $\sim 043$ & & \\
\hline 10 & 1686592 & 5394062 & VH west & $12 \pm 5$ & & w & $\mathrm{r}$ & tape measure & & & & & & $\sim 007$ & & \\
\hline 11 & 1686595 & 5394312 & VH west & $20 \pm 5$ & & w & $\mathrm{r}$ & tape measure & & & & & & $\sim 009$ & & \\
\hline 12 & 1686636 & 5394551 & VH west & $10 \pm 5$ & & w & $\mathrm{r}$ & tape measure & & & & & & $\sim 009$ & & \\
\hline 13 & 1686467 & 5394971 & $\mathrm{VH}$ west & $16 \pm 5$ & & w & ch & aerial photog. & & & & & & $\sim 009$ & & \\
\hline 14 & 1686913 & 5395605 & VH west & $30 \pm 10$ & & w & $\mathrm{r}$ & aerial photog. & & & & & & $\sim 022$ & & \\
\hline 16 & 1686935 & 5395965 & VH west & $35 \pm 10$ & & w & $r$ & aerial photog. & & & & & & $\sim 035$ & & \\
\hline 17 & 1687098 & 5396277 & VH west & $35 \pm 10$ & & w & $\mathrm{r}$ & aerial photog. & & & & & & $\sim 035$ & & \\
\hline 18 & 1687810 & 5395688 & $\mathrm{VH}$ east & $2.7 \pm 1$ & & w & $\mathrm{ch}$ & tape measure & & & & & & $\sim 071$ & & \\
\hline 19 & 1687841 & 5395735 & $\mathrm{VH}$ east & $3 \pm 1$ & $>1 \pm 0.5$ & w & $\mathrm{ch}$ & tape measure & & & & & $<3 \pm 2.5$ & $\sim 047$ & & \\
\hline 20 & 1687906 & 5395796 & VH east & $3.6 \pm 1$ & & w & ch & tape measure & & & & & & $\sim 047$ & & \\
\hline 21 & 1687980 & 5395874 & VH east & $3 \pm 1$ & $>1 \pm 0.5$ & w & $c h$ & tape measure & & & & & $<3 \pm 2.5$ & $\sim 055$ & & $244^{\circ}$ \\
\hline 22 & 1688013 & 5395925 & VH east & $6.5 \pm 1$ & $>2.5 \pm 1$ & w & ch & tape measure & & & & & $<2.6 \pm 1.4$ & $\sim 041$ & & \\
\hline 23 & 1686995 & 5396057 & VH west & & & NW & $\mathrm{fe}$ & compass & & & & & 1.2 & 050/NW/61 & $135^{\circ}$ & \\
\hline 24 & 1687869 & 5397159 & VH west & & & NW & fe & compass & & & & & 0.5 & 076/SE/77 & $60^{\circ}$ & $270^{\circ}$ \\
\hline 25 & 1687810 & 5395688 & VH east & & & NW & fe & compass & & & & & & 071/SE/62 & & \\
\hline 26 & 1687988 & 5395865 & VH east & & & NW & $\mathrm{fe}$ & compass & & & & & & 055/SE/66 & & \\
\hline 27 & 1687506 & 5393878 & Dumgree & $200 \pm 50$ & & & $\mathrm{fe}$ & aerial photog. & & & & & & $\sim 038$ & & \\
\hline 28 & 1687600 & 5394196 & Dumgree & $130 \pm 30$ & & & ch & aerial photog. & & & & & & $\sim 041$ & & \\
\hline 29 & 1687947 & 5394780 & Dumgree & $350 \pm 50$ & & & ch & aerial photog. & & & & & & $\sim 038$ & & \\
\hline 30 & 1688129 & 5395327 & Dumgree & $30 \pm 5$ & & & $r$ & aerial photog. & & & & & & $\sim 036$ & & \\
\hline 31 & 1688345 & 5395266 & Dumgree & & & & ch & aerial photog. & & & & & & $\sim 042$ & & \\
\hline 34 & 1688580 & 5397185 & Flaxey & $200 \pm 20$ & & & $\mathrm{ch}$ & aerial photog. & & & & & & $\sim 098$ & & \\
\hline 35 & 1688930 & 5397137 & Flaxey & $180 \pm 30$ & $>4 \pm 1$ & s & $\mathrm{ch}$ & RTK (Fig 5a) & $U p 1^{3}$ & $<119 \pm 21$ & $>1.5 \pm 0.5$ & $>0.03 \pm 0.01$ & $<45 \pm 13$ & $\sim 095$ & & \\
\hline 36 & 1688917 & 5397743 & Vernon & & $1.8 \pm 0.5$ & NW & ts & Scarp profile & $\mathrm{FGF}^{3}$ & $>13 \pm 1.2$ & & $<0.14 \pm 0.05$ & & $\sim 060$ & & \\
\hline 37 & 1689225 & 5396832 & VH east & $45 \pm 10$ & & NW & ch & aerial photog. & & & & & & $\sim 058$ & & \\
\hline 38 & 1689341 & 5396884 & $\mathrm{VH}$ east & $40 \pm 10$ & & NW & $\mathrm{ch}$ & aerial photog. & & & & & & $\sim 058$ & & \\
\hline 39 & 1689497 & 5398083 & Vernon & $8 \pm 2$ & & NW & $\mathrm{ch}$ & tape measure & & & & & & $\sim 063$ & & \\
\hline 40 & 1689582 & 5398115 & Vernon & $30 \pm 5$ & & NW & $\mathrm{ch}$ & tape measure & & & & & & $\sim 063$ & & \\
\hline 41 & 1689691 & 5398181 & Vernon & $3.3 \pm 2.4$ & & NW & $\mathrm{ch}$ & RTK (Fig. 5b) & & & & & & $\sim 070$ & & \\
\hline 42 & 1689868 & 5398312 & Vernon & $160 \pm 20$ & & NW & ch & aerial photog. & & & & & & $\sim 078$ & & \\
\hline 43 & 1690044 & 5398360 & Vernon & $<122$ & $>1.2$ & NW & ch & RTK (Fig. 6) & $\mathrm{Do} 2^{3}$ & $>30 \pm 5$ & $<4.9$ & $>0.04$ & $<100$ & $\sim 081$ & & $\sim 081^{\circ}$ \\
\hline
\end{tabular}

Table 1) Table of neotectonic measurements from the sites located in Figs. 2a,b, and c. ${ }^{1}$ Eastings and Northings are from the New Zealand Transverse Mercator 2000 (NZTM2000) projection system on the map NZTopo50-BR29. ${ }^{2} r h r=$ right hand rule. ${ }^{3}$ Shown in stratigraphic sections in Fig. 3. Feature abbreviations: $r=$ ridge, ts=terrace surface, $r f=$ =ridge flank, $c h=c h a n n e l, f e=f a u l t$ exposure. 


\subsection{The Active Vernon Fault: Structure and Displacement Rate}

I define three geometric sections of the Vernon Fault, including the southwestern Vernon Hills section, the central Big Lagoon section, and the northeastern Wairau Basin section (Fig. 1).

\subsubsection{Vernon Hills Section}

The Vernon Hills section includes the Dumgree, Vernon Hills western (VHWS), Vernon Hills eastern (VHES), and Flaxey splays (Figs. 1,2). The Vernon Hills section extends from the Vernon Fault's bifurcation from the Awatere Fault (Fig. 2a) to the intersection of the Big Lagoon and Flaxey splays (Fig. 2c). The Dumgree splay bifurcates from the Awatere Fault at a strike of $\sim 032^{\circ}$ and continues for $\sim 1 \mathrm{~km}$ to where it steps $\sim 1.5 \mathrm{~km}$ northwards, bending initially into a $\mathrm{N}$-striking $\left(\sim 000^{\circ}\right)$ segment and then back to $\sim 045^{\circ}$ (Fig. 2a). Southwest of Stafford Creek the Dumgree splay displaces bedrock ridges and the SCf on the banks of tributaries of Stafford Creek (Fig. 2a). Northeast of Stafford Creek the Dumgree splay has little surface expression in the actively eroding gullies and ridges through the Vernon Hills (Fig 2b). Here the Dumgree splay is mainly traced by measuring dextral displacements at sites 9 and 27-32 (Fig. 2b, Table 1) and mapping fault related topography. The Dumgree splay terminates at a left step-over onto the Vernon Hills eastern splay. The Dumgree splay's surface expression is mainly upthrown to the W-NW (Fig. 2a). There is no exposure of the fault but it can be estimated as near vertical due to lack of "veeing" of the fault trace through valleys and ridges. 
a)

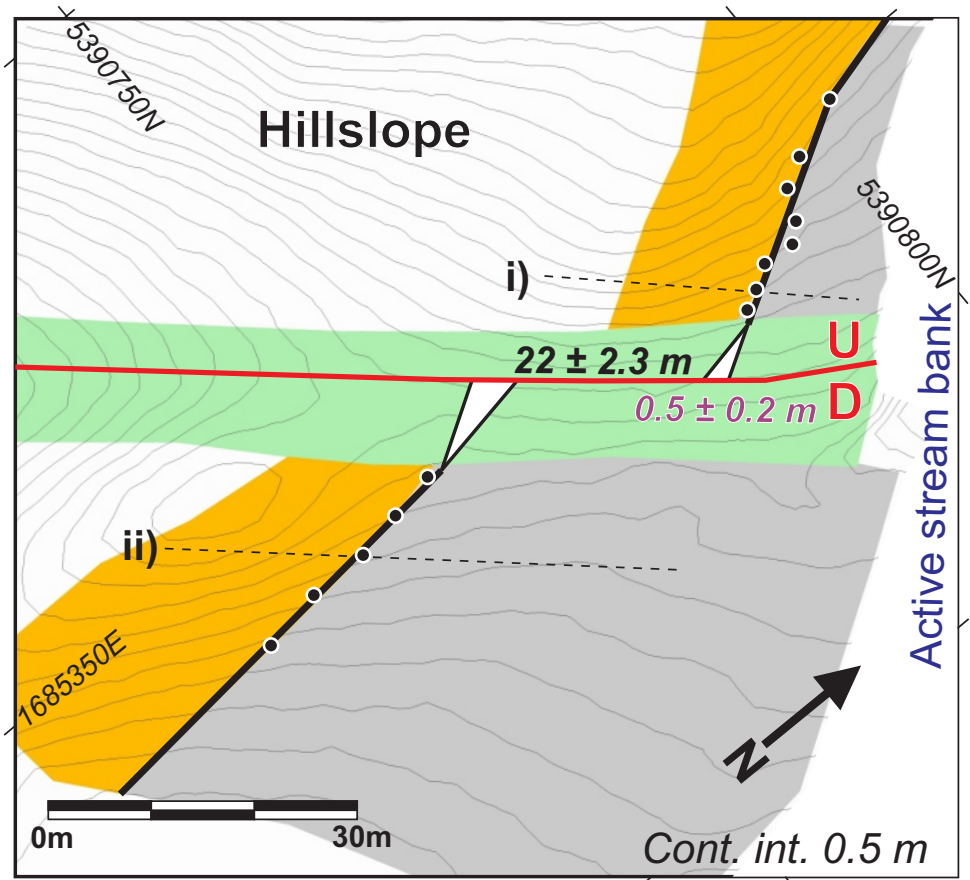

b)

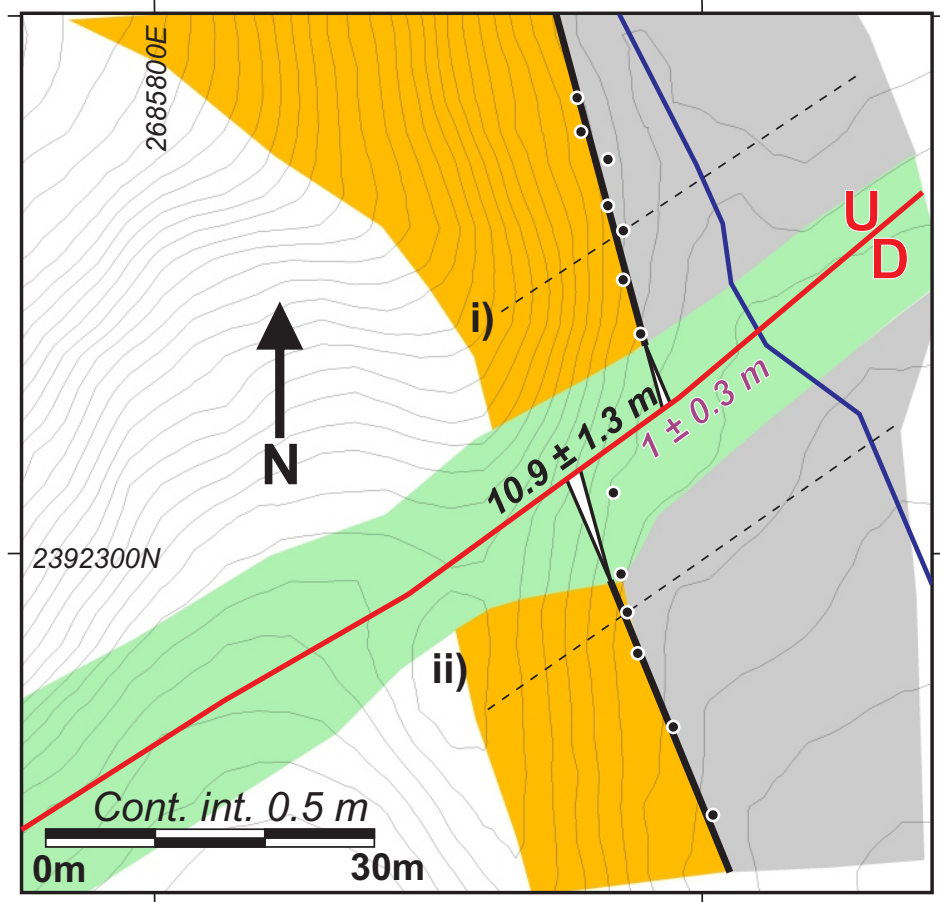

Scale for all profiles

20m No VE

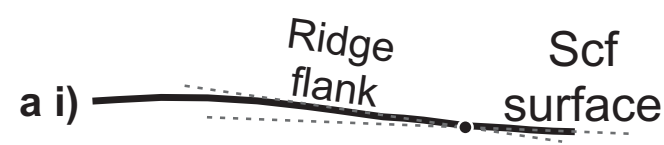

a ii) Ridge

flank

Scf surface

\section{Explanation}

${ }_{10} \times 4^{m}$ Dextral disp.

$2^{*} 1^{m}$ Vertical disp.

Intersection of

- ridge flank and Scf picked in profiles

$\nabla \leftarrow$ Error triangle

Line of depositional ridge flank
Stafford Creek aggradational fan surface

Pre-onlap ridge flank

b i) $\underbrace{R_{i d}}$ flank

Scarp related topography

Fault

Active Stream

Profile

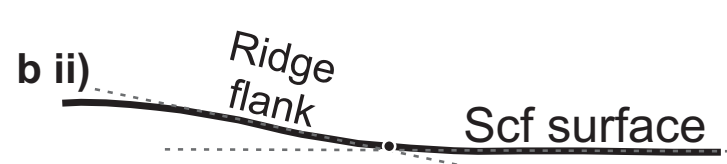


Figure 4) Interpreted RTK derived topo-maps of displaced landforms in the Vernon Hills section, displaced by the Dumgree splay. Shows dextral and vertical displacement of the ridge flank-SCf tread intersection and the SCf surface respectively. Profiles below the maps present how these intersections were found and the maps show how they were subsequently projected to the fault. a) is from site 2 while b) is from site 7 [Fig. 2a; Table 1].

Two displacements of the SCf terrace edge by the Dumgree splay, where the SCf has aggraded against ridge flanks, were measured using the RTK GPS derived topographic maps (Fig. 4). Since the terrace edge has been formed during aggradation of the SCf against an existing ridge flank that could have already accumulated offset (before $21 \pm 1 \mathrm{ka}$ ), the dextral slip-rates obtained from these measurements are inferred to be maxima. At site 2 (Fig. 2a), the Dumgree splay dextrally displaces the eastern flank of a ridge onlapped by the SCf by $22 \pm 3.6 \mathrm{~m}$ (Fig. 4a). Thirteen profiles were constructed parallel to the fault to locate the intersection between the ridge flank and the SCf tread on both sides of the fault (black projection line). The throw was estimated to be $0.5 \pm 0.2 \mathrm{~m}$ by profiling the height of the scarp on the SCf. The N-striking section of the Dumgree splay has a $<4 \pm 1$ $\mathrm{m}$ high scarp in the SCf at site 3 (Appendix B8,9). Elsewhere on the $\mathrm{N}$-striking section on the Dumgree splay two ridges have been displaced dextrally by $65 \pm 15 \mathrm{~m}$ and $70 \pm 15 \mathrm{~m}$, but throw has not been measured (sites 4,5; Fig 2a). At site 7 a ridge flank mantled by the edge of the SCf is displaced by the Dumgree splay (Fig. 4b). I used the same method as used at site 2 , to measure a dextral displacements of $10.9 \pm 0.3 \mathrm{~m}$ of the SCf terrace edge and a $1 \pm 0.3 \mathrm{~m}$ high scarp in the SCf. These displacements collectively indicate dextral slip rates of $<1.0 \pm 0.3 \mathrm{~mm} / \mathrm{yr}$ and dip-slip rate of $<0.19 \pm 0.04 \mathrm{~mm} / \mathrm{yr}$ on the Dumgree splay. A dextral component is measured everywhere along the Dumgree splay with high $(>10) \mathrm{H} / \mathrm{V}$ ratio in the NE striking segments. The north striking segment is estimated to have a lower $\mathrm{H} / \mathrm{V}$ ratio based on a higher vertical rate $(0.2 \mathrm{~mm} / \mathrm{yr})$ and a possible lower 
$\mathrm{H} / \mathrm{V}$ ratio of $>2$ in the displacement of a ridge at site 6 (Fig. 2a). The Dumgree splay strikes $\sim 035^{\circ}$ at site 6 , so could have a lower $\mathrm{H} / \mathrm{V}$ where it strikes $000^{\circ}$.

The Vernon Hills eastern and western splays are poorly expressed through the actively eroding ridge and gully topography (Fig. $2 \mathrm{~b}, \mathrm{C})$. Both of these splays have fault exposures are steeply dipping $\left(>60^{\circ}\right)$ with a reverse component of motion, dipping to the SE (sites 24-26 in Fig. 2b). The Vernon Hills western splay has not been found in the banks of Stafford Creek so the southwest tip of the splay is about $1 \mathrm{~km}$ north of the Dumgree splay, in the Vernon Hills. It strikes $010^{\circ}$ in the south and bends clockwise northwards through the section to a strike of $\sim 065^{\circ}$, where it intersects with the Flaxey Splay near site 33 (Fig. 2c). Step-overs that include topographic bulges and a sag pond have been mapped on the Vernon Hills western splay trace near sites 14-17 (Fig. 2b). Eight 10-60 m dextral displacements of landforms have been measured (sites 10-17 in Fig. 2b), but the vertical displacements of the features are undefined. The best indicators of the vertical component on the Vernon Hills western splay are the fault exposures where slickenlines have been measured (Fig. 2b). At site 24 slickenlines on the fault plane have a rake of $60^{\circ}$ from the northeast end of strike indicating more dip slip than strike slip with an $\mathrm{H} / \mathrm{V}$ of $\sim 0.5$. In contrast, at site 23 , the Vernon Hills western splay has a normal component in an exposure at a hillslope stream, dipping $61^{\circ} \mathrm{NW}$ and slickenlines that have a rake of $45^{\circ}$ from the southwest end of strike $(H / V \sim 1.2)$. 
a)

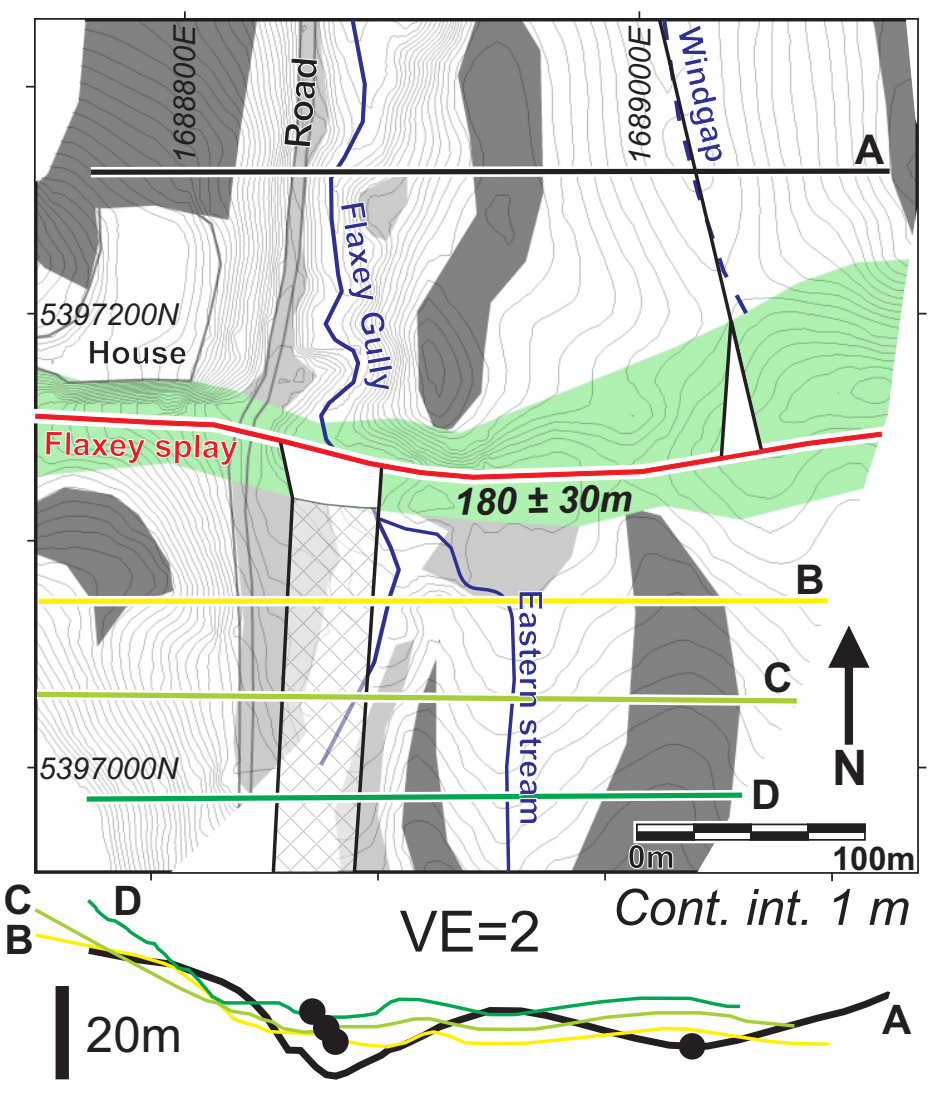

b)

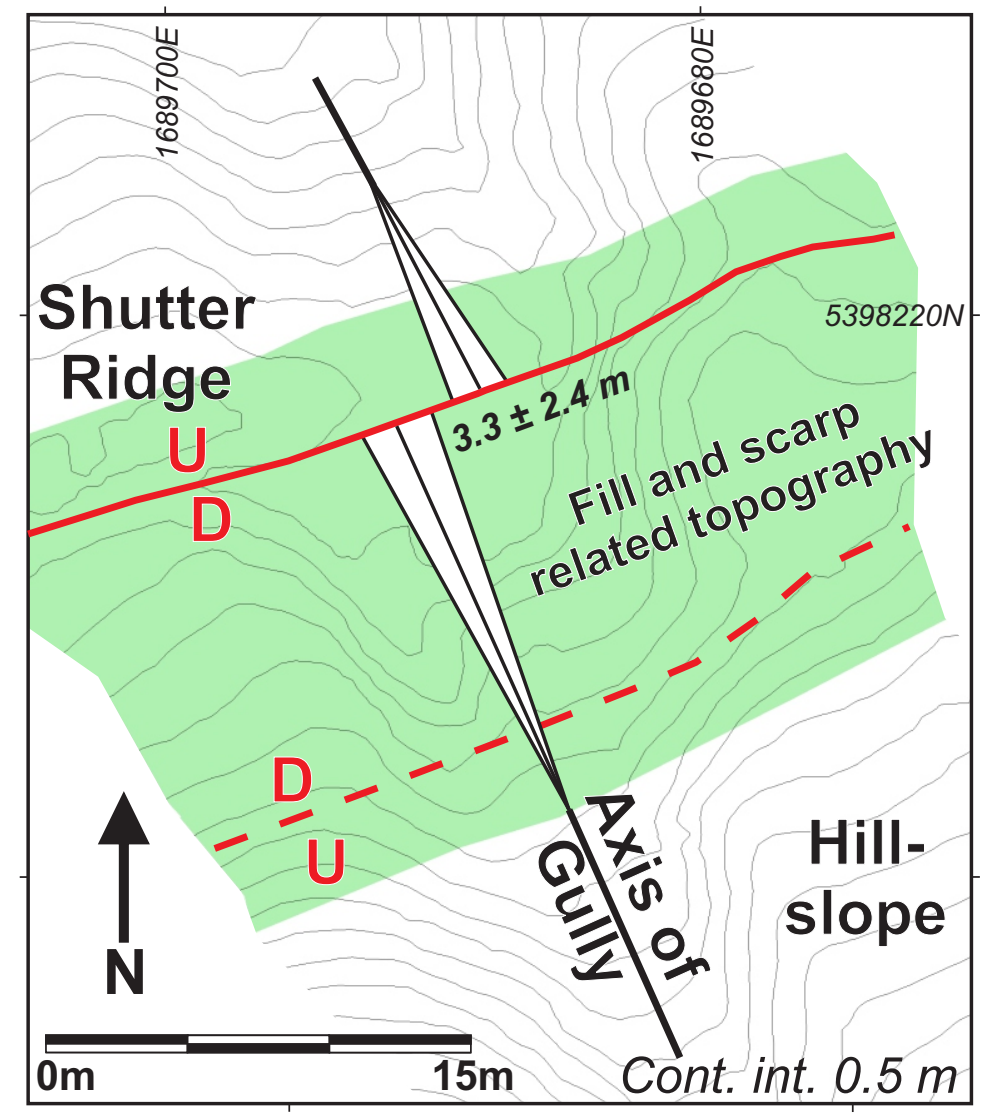

\section{Explanation}

Uncertainty in axis of Gully

Flaxey Gully fan surface

Upton 1 river terrace

Scarp related topography

\section{Fault}

- Inferred Fault

Active Stream

$10 \times 4$ Dextral disp.

- Inactive Stream

$\bigvee \begin{aligned} & \text { Error triangle } \\ & \text { Trend of feature }\end{aligned}$
Figure 5) RTK GPS survey derived topographic maps of displacements on the Flaxey splay and the Vernon fault. a) Flaxey Splay dextrally displacing Windgap Gully $180 \pm 30 \mathrm{~m}$ from the stream on the southern block at site 35 (Fig 2c, Table 2). Profiles A, B, C, D below the diagram are from the straight bold lines on the map. b) Hillslope channel offset over two possible splays with a graben type feature between them at site 41 (Fig 2c, Table 2). 
The Vernon Hills eastern splay is $\sim 2.5 \mathrm{~km}$ long, strikes $\sim 060^{\circ}$, and bifurcates into two at its western end, where it overlaps the northeastern part of the Dumgree splay by 1 km with a step-over width of $600-700 \mathrm{~m}$ (Fig. 2b). The eastern end of the splay terminates at its $45^{\circ}$ intersection with the Flaxey splay. Fault exposures at sites 25 and 26 (Fig. 2b) show that the Vernon Hills eastern splay has a reverse component, dipping $62^{\circ}$ and $66^{\circ} \mathrm{SE}$ respectively. The reverse component is best estimated by the 3-6.5 m dextral and >1-2.5 m vertical displacements of three hill-slope channels at sites 19 to 22 (Fig. 2b), indicating $\mathrm{H} / \mathrm{V}$ ratios of $<5.5$. The vertical displacements are minima because the channels are active, possibly resulting in erosion on the upthrown side of the fault and deposition on the downthrown side. These data collectively indicate that the Vernon Hills eastern and western splays are characterised by variable dextral and reverse components with $\mathrm{H} / \mathrm{V}$ ratios varying from 0.5-5.5.

The Flaxey splay is $\sim 1.9 \mathrm{~km}$ long, strikes E-W, and terminates where it intersects the Vernon Hills western splay in the west and the Vernon Hills eastern splay in the east. The fault is downthrown to the south, displacing the highly dissected Upton 1 terrace (Fig. 2c). East of Flaxey Gully on the upthrown block, a windgap (abandoned stream) is cut $10 \mathrm{~m}$ deep and $100 \mathrm{~m}$ wide into the $\sim 120 \mathrm{ka}$ Upton 1 terrace (Fig. 5a). The windgap was once occupied by a stream that flowed across the fault scarp from the south. It is hard to identify an exact upstream source for the windgap because two streams are present on the southern block, the active Flaxey Gully stream and a small stream to the east of it. Compared to the windgap, Flaxey Gully has the most similar gully width and depth and also has a larger catchment to incise a windgap of that scale (Fig. 5a). Beheading of the windgap must have occurred after abandonment of the Upton 1 terrace so the age constraint of the terrace (119 $\pm 21 \mathrm{ka})$ is a maximum age. The windgap has been dextrally displaced by a maximum of $180 \pm$ $30 \mathrm{~m}$, indicating that Flaxey splay has a dextral slip rate of $>1.5 \pm 0.5 \mathrm{~mm} / \mathrm{yr}$. A profile that follows the channels of the windgap and the upstream Flaxey Gully show there is a minimum throw of $4 \pm 1$ 
$\mathrm{m}$ since the deposition of the Upton 1 terrace. This is a minimum estimate because there has been erosion on the upthrown side and deposition of the SCf on the downthrown side. These data indicate the displacement on the Flaxey splay is predominantly dextral $(H / V<45 \pm 13)$, with a subordinate dip slip rate of $>0.03 \pm 0.01 \mathrm{~mm} / \mathrm{yr}$.

\subsubsection{Big Lagoon Section}

The Big Lagoon section of the Vernon Fault is about $19 \mathrm{~km}$ in length, and extends from the intersection of the Vernon Hills western and Flaxey splays, along the base of the hill slope adjacent to Big Lagoon, to a significant stepover in the fault trace $\sim 9.5 \mathrm{~km}$ offshore (Fig. 1). Onshore the fault displaces late Quaternary river terraces southwest of Homestead Stream and is buried by active alluvial fans sourced from the Vernon Hills NE of Homestead Stream (Fig. 2c). A bend in the trace near the Balfour trench site separates traces that have strikes of $\sim 060^{\circ}$ in the west from $\sim 074^{\circ}$ in the east (Fig. 1). About $150 \mathrm{~m}$ NE of Flaxey Gully a dilational step-over is apparent by the presence of a sag pond about $80 \mathrm{~m}$ long and $20 \mathrm{~m}$ wide in the surface of the SCf (Fig. 2c). Here low vertical rates of $<0.14 \pm 0.05 \mathrm{~mm} / \mathrm{yr}$ have been measured where the fault displaces the FGf vertically by $1.8 \pm 0.5 \mathrm{~m}$ [Clark et al., 2011b] (site 36, Fig. 2c). The fault scarp also changes facing directions on a kilometre scale, downthrown to the northwest near Flaxey Gully and to the southeast at the Balfour trench site. Dextral displacements of hillslope channels by $<45 \pm 10 \mathrm{~m} 300-800 \mathrm{~m}$ southwest of the Balfour trench site indicate the fault is predominantly dextral. At site 41 , a hillslope channel has a dextral displacement of $3.3 \pm 2.4 \mathrm{~m}$, measured across an inferred step-over graben (Fig. 5b). These combined observations indicate that the fault is predominantly strike slip. 
The only dextral displacement of a datable fluvial terrace on the Big Lagoon section of the Vernon Fault was measured near the Balfour trench site [Clark et al., 2011b], (Fig. 6). Homestead Stream is incised into the Do2 surface to the north of the fault. An alluvial fan sourced from Homestead stream has been deposited against the fault scarp, infilling the fault depression (Fig. 6). Because other streams to the northeast have variable positions on active fans derived from the adjacent hills (Fig. 2c), there is uncertainty in the position of Homestead Stream across the alluvial fan at the Balfour trench site (Fig. 6). I measured a dextral displacement of Homestead Stream of $<122 \mathrm{~m}$, a maximum because the stream could have originally curved eastwards on the fan, reducing the apparent displacement. The maximum displacement of Homestead Stream together with an $30 \pm 5$ ka age of the Do2 terrace yields a dextral slip rate of $<4.9 \mathrm{~mm} / \mathrm{yr}$. The dip-slip displacement of $>1.2$ $\mathrm{m}$ measured close to the Balfour trench is a minimum because the alluvial fan tapers towards the east and abuts the scarp, partially filling in the depression (Fig. 6).

The offshore part of the Big Lagoon section is imaged in boomer seismic lines 1 to 3 (Fig. 1). The fault has a strike of $073^{\circ}$ near the coast, but swings $E-W$ about $7 \mathrm{~km}$ from shore. The fault is upthrown to the south which is consistent with the elevated topography on land south of Big Lagoon, and with uplift of a contiguous near-shore bathymetric reef between the Vernon and Awatere faults (Fig. 9a; See also Fig. 5c in Pondard and Barnes, [2010]). The fault appears to dip to the south, and its dip is estimated tentatively to be $60-85^{\circ}$ (Table 2). In the seismic lines the PGS2/1 surface is displaced vertically by 9.6-10.9 $\mathrm{m}$ (Fig. 9a-e, Table 2). Considering the diachronous age of PGS2/1, the displacements indicate a vertical rate of at least $0.86 \pm 0.20 \mathrm{~mm} / \mathrm{yr}$ on line 1 west of the bend, and $0.59 \pm 0.14 \mathrm{~mm} / \mathrm{yr}$ on line 3 to the east (Fig. $7 \mathrm{~b}$, Table 2). Slightly higher vertical rates are apparent from the displacements of the younger Holocene coloured reflectors (Fig. 7c). These relatively high vertical rates on the immediate offshore part of the Big Lagoon section raise the possibility that higher than average vertical rates also occur onshore, where the fault is hidden beneath the base of the hillslope immediately adjacent to Big Lagoon, northeast of the Balfour trench site. 

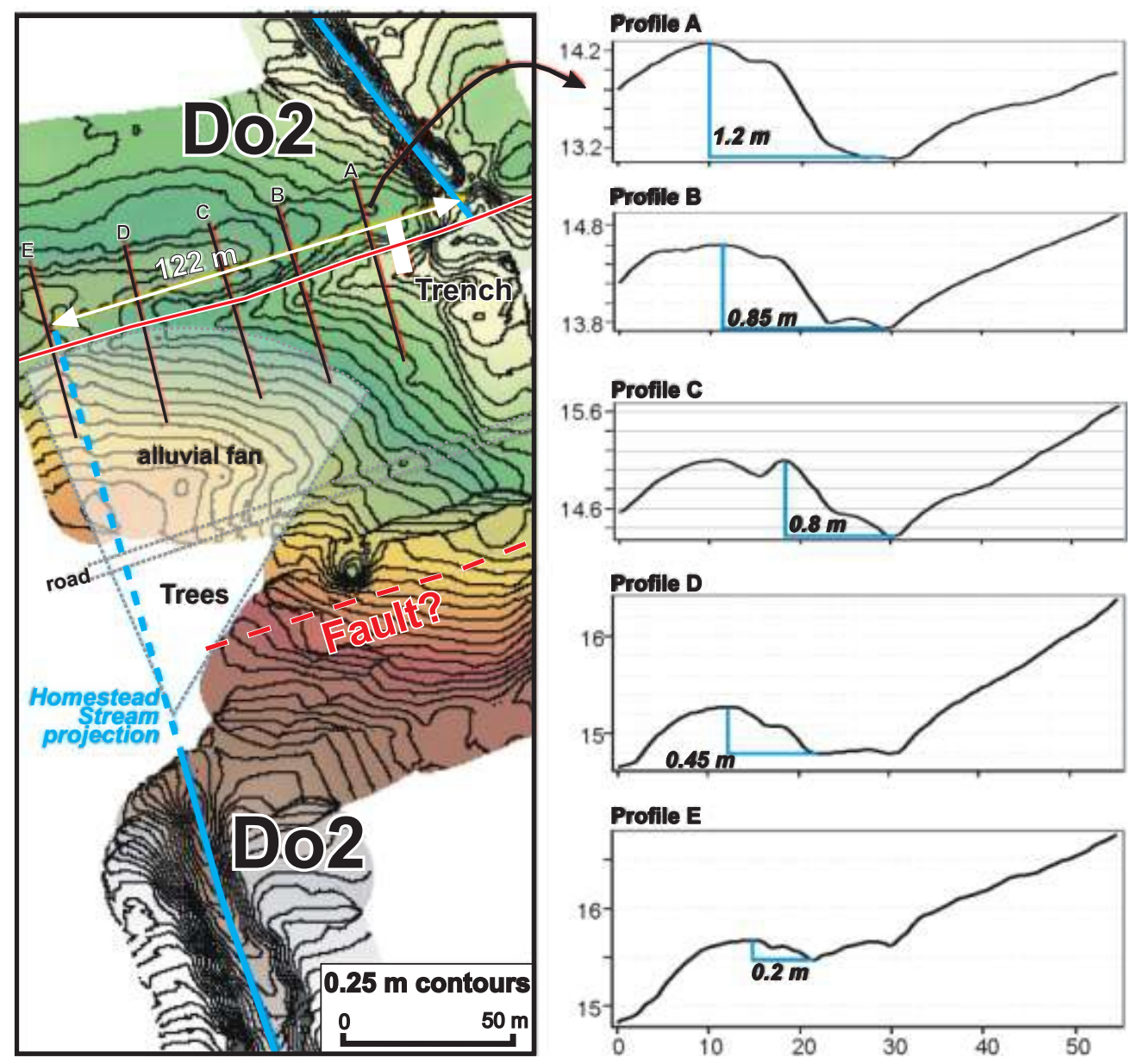

Figure 6) RTK GPS derived topographic map of the dextral displacement of Homestead stream by the Vernon Fault near the Balfour trench (white box) at site 43 (Fig 2a, Table 2). The Homestead stream is cut into the Downs 2 (Do2) terrace and could have flowed down the alluvial fan at some route, shown by the white translucent area of uncertainty. Profiles on the right show the scarp topography and the infilling of the scarp by the alluvial fan. Figure from Clark et al., [2011] 


\subsubsection{Wairau Basin Section}

The Wairau Basin section of the Vernon Fault is $19 \mathrm{~km}$ in length, strikes E-W, reasonably straight, and imaged in seismic lines 3-12, 19 and DG01 (Fig. 1, Table 2) [Pondard and Barnes, 2010]. I interpret the western end of the section to overlap the Big Lagoon section by $2.4 \mathrm{~km}$, with a right step-over width of 0.4-1.0 km. The eastern end terminates beneath the outer continental shelf. The fault is upthrown to the south and steeply dipping $\left(>70^{\circ}\right)$, indicating a reverse component of displacement (Figs. 7a, 9b-d). In multichannel seismic section DG01 (Fig. 7a), the dip of the fault is estimated at 60$80^{\circ}$, down to a depth of $\sim 5-6 \mathrm{~km}$. I estimate a similar dip for depths $<100 \mathrm{~m}$ from boomer seismic lines 11,12 , and $19\left(55-85^{\circ}\right)$ (Table 2). A releasing step-over is interpreted across line 10 (Fig. 9e), where a $0.4 \mathrm{~km}$ wide graben is imaged, with two opposing faults. Whilst I have no direct observations of dextral displacement, the occurrence of subsidence in the step-over region, in contrast to the consistent reverse component elsewhere on the fault section, is consistent with predominantly strike-slip displacement [Pondard and Barnes, 2010]. 


\begin{tabular}{|c|c|c|c|c|c|c|c|c|c|}
\hline Line & $\begin{array}{c}\text { Dist. from } \\
\text { coast } \\
(\mathrm{km}) \\
\end{array}$ & $\operatorname{Dip}\left({ }^{\circ}\right)$ & $\begin{array}{c}\text { Dip } \\
\text { Direction }\end{array}$ & Reflector & $\begin{array}{l}\text { Age of } \\
\text { reflector } \\
\text { (ka) }\end{array}$ & $\begin{array}{c}\text { Local vertical } \\
\text { displacement } \\
(\mathrm{m})\end{array}$ & $\begin{array}{c}\text { Long } \lambda \text { vertical } \\
\text { displacement } \\
(\mathrm{m})\end{array}$ & $\begin{array}{l}\text { Local vert. } \\
\text { disp. rate } \\
(\mathrm{mm} / \mathrm{yr}) \\
\end{array}$ & $\begin{array}{c}\text { Long } \lambda \text { vert. } \\
\text { disp. rate } \\
(\mathrm{mm} / \mathrm{yr}) \\
\end{array}$ \\
\hline 1 & 4.7 & $55-85$ & SE & PGS2/1 & $12.6 \pm 0.5$ & $6.2 \pm 1$ & $10.9 \pm 2.1$ & $0.49 \pm 0.1$ & $0.86 \pm 0.2$ \\
\hline \multirow[t]{2}{*}{2} & 6.5 & $>60$ & SE & PGS2/1 & $13.9 \pm 0.6$ & $2.5 \pm 0.7$ & $10.2 \pm 3.6$ & $0.18 \pm 0.06$ & $0.73 \pm 0.29$ \\
\hline & & & & orange & $6.2 \pm 1.1$ & $2.7 \pm 0.4$ & $5.6 \pm 0.7$ & $0.44 \pm 0.14$ & $0.91 \pm 0.28$ \\
\hline \multirow[t]{2}{*}{3} & 9 & $>70$ & SE & PGS2/1 & $16.4 \pm 0.8$ & & $9.6 \pm 1.8$ & & $0.59 \pm 0.14$ \\
\hline & & & & red & $8.4 \pm 1.6$ & & $6.2 \pm 1.1$ & & $0.74 \pm 0.27$ \\
\hline \multirow[t]{2}{*}{4} & 11 & & & red & $8.4 \pm 1.6$ & & $3.6 \pm 1.8$ & & $0.43 \pm 0.30$ \\
\hline & & & & orange & $6.2 \pm 1.1$ & & $3.6 \pm 1.8$ & & $0.59 \pm 0.40$ \\
\hline \multirow[t]{4}{*}{5} & 12.3 & $50-80$ & SE & PGS2/1 & $17 \pm 0.9$ & $3.5 \pm 0.3$ & $3.2 \pm 0.4$ & $0.20 \pm 0.03$ & $0.19 \pm 0.03$ \\
\hline & & & & turquoise & $10.3 \pm 2.1$ & $2.9 \pm 0.2$ & $4.7 \pm 0.4$ & $0.28 \pm 0.08$ & $0.46 \pm 0.13$ \\
\hline & & & & red & $8.4 \pm 1.6$ & $2.2 \pm 0.2$ & $4.5 \pm 0.3$ & $0.26 \pm 0.07$ & $0.54 \pm 0.14$ \\
\hline & & & & orange & $6.2 \pm 1.1$ & $2.0 \pm 0.2$ & $4.1 \pm 0.3$ & $0.32 \pm 0.09$ & $0.66 \pm 0.16$ \\
\hline \multirow[t]{4}{*}{6} & 14 & $>70$ & SE & PGS2/1 & $17.9 \pm 0.6$ & $0.9 \pm 0.2$ & $5.0 \pm 0.4$ & $0.05 \pm 0.1$ & $0.28 \pm 0.03$ \\
\hline & & & & turquoise & $10.3 \pm 2.1$ & $0.7 \pm 0.2$ & $4.1 \pm 0.4$ & $0.07 \pm 0.03$ & $0.39 \pm 012$ \\
\hline & & & & red & $8.4 \pm 1.6$ & $0.7 \pm 0.2$ & $2.9 \pm 0.4$ & $0.09 \pm 0.04$ & $0.35 \pm 0.11$ \\
\hline & & & & orange & $6.2 \pm 1.1$ & $0.5 \pm 0.2$ & $2.9 \pm 0.4$ & $0.09 \pm 0.05$ & $0.47 \pm 0.14$ \\
\hline \multirow[t]{5}{*}{7} & 15.8 & $>70$ & NW & PGS2/1 & $19.3 \pm 0.5$ & $6.6 \pm 1.1$ & $2.8 \pm 0.4$ & $0.34 \pm 0.07$ & $0.15 \pm 0.02$ \\
\hline & & & & yellow & $14 \pm 3.8$ & $4.7 \pm 0.7$ & $2.4 \pm 0.4$ & $0.34 \pm 0.14$ & $0.17 \pm 0.07$ \\
\hline & & & & turquoise & $10.3 \pm 2.1$ & $3.8 \pm 0.7$ & $1.5 \pm 0.5$ & $0.38 \pm 0.15$ & $0.14 \pm 0.08$ \\
\hline & & & & red & $8.4 \pm 1.6$ & $4.2 \pm 0.4$ & $2.2 \pm 0.2$ & $0.49 \pm 0.14$ & $0.26 \pm 0.11$ \\
\hline & & & & orange & $6.2 \pm 1.1$ & $3.6 \pm 0.4$ & $1.8 \pm 0.2$ & $0.59 \pm 0.16$ & $0.29 \pm 0.08$ \\
\hline \multirow[t]{5}{*}{8} & 17.3 & $60-80$ & & PGS2/1 & $19.3 \pm 0.5$ & & $3.2 \pm 0.4$ & & $0.16 \pm 0.01$ \\
\hline & & & & yellow & $14 \pm 3.8$ & & $2.3 \pm 0.2$ & & $0.17 \pm 0.06$ \\
\hline & & & & turquoise & $10.3 \pm 2.1$ & & $2.7 \pm 0.2$ & & $0.26 \pm 0.07$ \\
\hline & & & & red & $8.4 \pm 1.6$ & & $2.5 \pm 0.3$ & & $0.30 \pm 0.09$ \\
\hline & & & & orange & $6.2 \pm 1.1$ & & $2.5 \pm 0.3$ & & $0.41 \pm 0.12$ \\
\hline \multirow[t]{4}{*}{9} & 18.5 & $>70$ & SE & PGS2/1 & $19.8 \pm 0.4$ & $1.8 \pm 0.2$ & $1.6 \pm 0.2$ & $0.09 \pm 0.01$ & $0.08 \pm 0.1$ \\
\hline & & & & yellow & $14 \pm 3.8$ & $0.5 \pm 0.2$ & $1.7 \pm 0.2$ & $0.04 \pm 0.02$ & $0.12 \pm 0.05$ \\
\hline & & & & red & $8.4 \pm 1.6$ & $1.1 \pm 0.2$ & $1.5 \pm 0.2$ & $0.13 \pm 0.05$ & $0.18 \pm 0.06$ \\
\hline & & & & orange & $6.2 \pm 1.1$ & $0.9 \pm 0.3$ & $2.2 \pm 0.4$ & $0.15 \pm 0.07$ & $0.35 \pm 0.12$ \\
\hline \multirow[t]{3}{*}{10} & 20.4 & ns $>75$ & SE & PGS2/1 & $20.1 \pm 0.3$ & $4.9 \pm 1.1$ & $3.4 \pm 1.1$ & $0.25 \pm 0.06$ & $0.17 \pm 0.06$ \\
\hline & & ss $>75$ & SE & red & $8.4 \pm 1.6$ & & $1.5 \pm 0.4$ & & $0.17 \pm 0.08$ \\
\hline & & & & orange & $6.2 \pm 1.1$ & & $0.7 \pm 0.4$ & & $0.12 \pm 0.08$ \\
\hline \multirow[t]{3}{*}{11} & 22 & $55-85$ & SE & PGS2/1 & $20.2 \pm 0.3$ & & $3.0 \pm 0.3$ & & $0.15 \pm 0.02$ \\
\hline & & & & red & $8.4 \pm 1.6$ & & $2.6 \pm 0.2$ & & $0.31 \pm 0.08$ \\
\hline & & & & orange & $6.2 \pm 1.1$ & & $1.5 \pm 0.2$ & & $0.23 \pm 0.07$ \\
\hline \multirow[t]{3}{*}{12} & 26 & $>60$ & SE & PGS2/1 & $20.3 \pm 0.3$ & $1.3 \pm 0.3$ & $2.2 \pm 0.4$ & $0.06 \pm 0.01$ & $0.06 \pm 0.01$ \\
\hline & & & & red & $8.4 \pm 1.6$ & $1.1 \pm 0.2$ & $2.0 \pm 0.2$ & $0.13 \pm 0.05$ & $0.13 \pm 0.005$ \\
\hline & & & & orange & $6.2 \pm 1.1$ & $0.7 \pm 0.3$ & $1.8 \pm 0.2$ & $0.11 \pm 0.06$ & $0.12 \pm 0.06$ \\
\hline \multirow[t]{3}{*}{19} & 24.7 & $>60$ & SE & PGS2/1 & $3.5 \pm 0.3$ & $3.5 \pm 0.3$ & $4.7 \pm 0.4$ & $0.17 \pm 0.02$ & $0.24 \pm 0.02$ \\
\hline & & & & red & $1.1 \pm 0.2$ & $1.1 \pm 0.2$ & $2.2 \pm 0.2$ & $0.13 \pm 0.05$ & $0.26 \pm 0.07$ \\
\hline & & & & orange & $0.9 \pm 0.2$ & $0.9 \pm 0.2$ & $1.9 \pm 0.3$ & $0.15 \pm 0.06$ & $0.31 \pm 0.10$ \\
\hline DG01 & 16.5 & $60-80$ & SE & & & & & & \\
\hline
\end{tabular}

Table 2) Late Quaternary dip-slip data and fault geometry from offshore seismic lines from TANO510 and DG01. For line 10: ns=northern splay, ss=southern splay. Local vertical displacements were measured by the depth difference of the displaced reflectors across the fault plane while long wavelength $(\lambda)$ vertical displacements were measured by the depth difference of displaced reflectors projected $>1 \mathrm{~km}$ from either side of the fault. 
Fig. 7

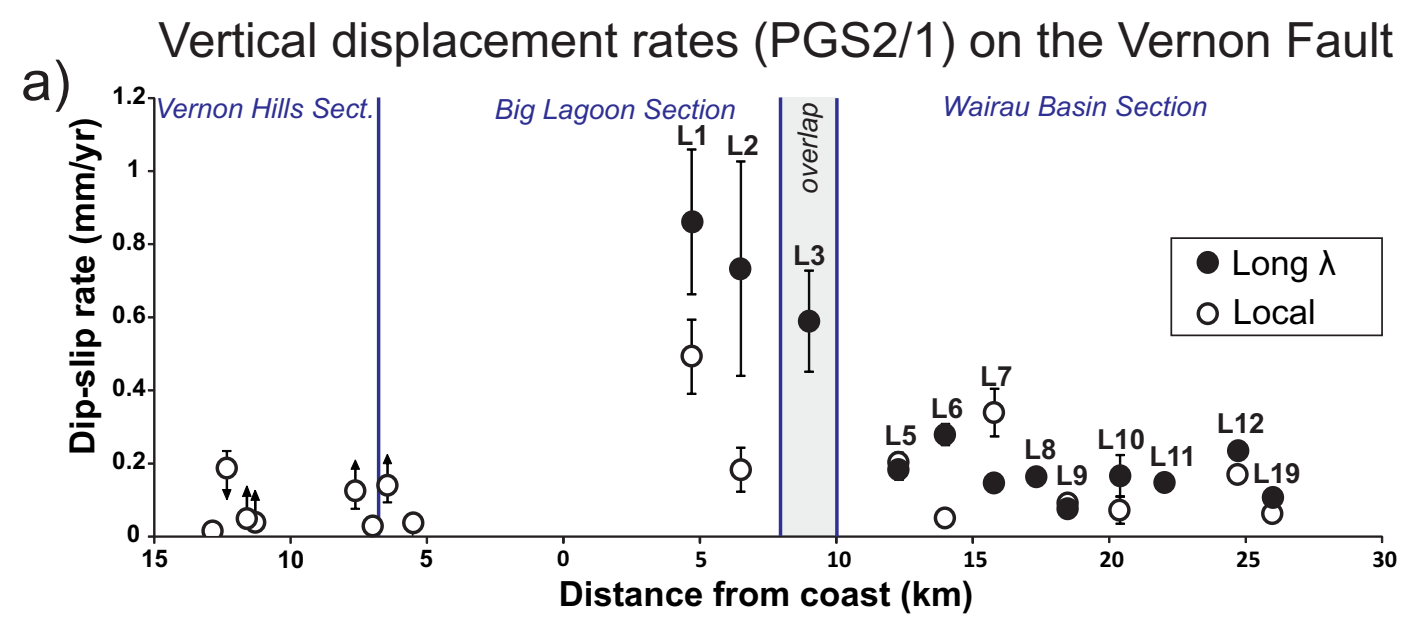

Offshore long $\lambda$ vertical displacement

rates on the Vernon fault

b)

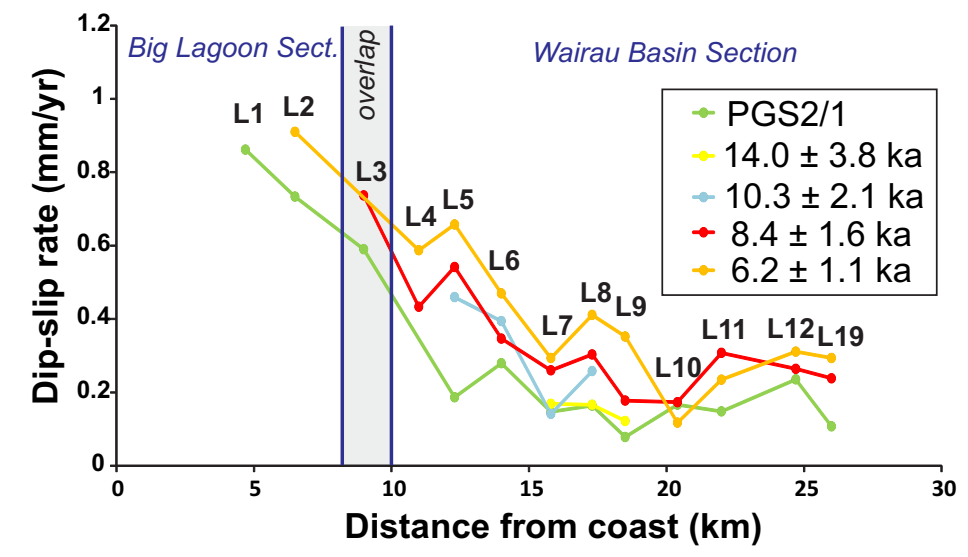

Figure 7 a) Onshore and offshore vertical displacement rates from the regional and local measurements of vertical displacement b) Offshore vertical displacement rates from regional measurements of vertical displacement of different aged reflectors. 
Vertical displacements of the PGS2/1 surface on boomer seismic lines 3-12 and 19, range from $1.6 \pm$ $0.2 \mathrm{~m}$ to $5.0 \pm 0.4 \mathrm{~m}$ (Table 2 , Fig. 9b-e). These displacements yield vertical slip rates of about 0.1-0.2 $\mathrm{mm} / \mathrm{yr}$ in the east, rising to $>0.6 \mathrm{~mm} / \mathrm{yr}$ approaching the step-over with the Big Lagoon section (Table 2). The vertical slip rates derived from local fault displacements are less than the long wavelength $(\sim 1 \mathrm{~km})$ displacements (Table 2, Fig. $7 \mathrm{~b}$ ), and exhibit some variability resulting from along-strike differences in the partitioning of the vertical deformation between local faulting and longer wavelength folding. Both methods applied to variable age reflectors, however, indicate that the vertical rate on the fault is highest along the margin of the nearshore bathymetric reef [Pondard and Barnes, 2010], with slightly higher rates apparent in the Holocene reflectors. The tip of the fault is completely buried by Late Holocene ( $<3 \mathrm{ka}$ ) sediment that was deposited since the last earthquake ruptured the seafloor. 


\subsection{Paleoseismicity of the Vernon Fault}

\subsubsection{Onshore Paleoseismic Record}

The Balfour trench (Fig. 8) was excavated across an uphill-facing scarp of the Vernon fault, across a north strand of a releasing step-over, on the Big Lagoon section, near Homestead Stream (Fig. 1) [Clark et al., 2011b]. A second possible southern strand of the fault nearer the base of the hillslope at this site may be masked by a road (Fig. 6). An artificial farm pond banks up against the scarp to the east of the trench and is inferred to be a fault sag pond. Alternatively the scarp trenched reflects an along-strike change in the sense of throw on the fault and the swamp is a result of ponding against it.

Alluvial gravels, sand, silt, organic peat and aeolian silt are exposed in the trench, and variably displaced down to the south (Fig. 8). The gravels consist of poorly-sorted subrounded to subangular pebbles and cobbles of greywacke that are variably matrix to clast supported. The silts are not bedded, stiff and orange-grey to brown, and contain scattered gravels clasts. On the north side of the fault is a terrace-coverbed sequence (Fig. 8), including unit 11, a massive silt with rare greywacke clasts $<1 \mathrm{~cm}$ in diameter. An OSL age of $31 \pm 3.2 \mathrm{ka}$ (Sample Balfour 1; Fig. 8) was measured from

Figure 8) Trench logs from the paleoseismic trench near Homestead Stream. Units are described in Appendix $C$, numbers in black. Faults and fault numbers are in red. OSL ages are in green and ${ }^{14} \mathrm{C}$ dates are in orange. MnO rich layer is the brown line. 
Balfour trench-west wall

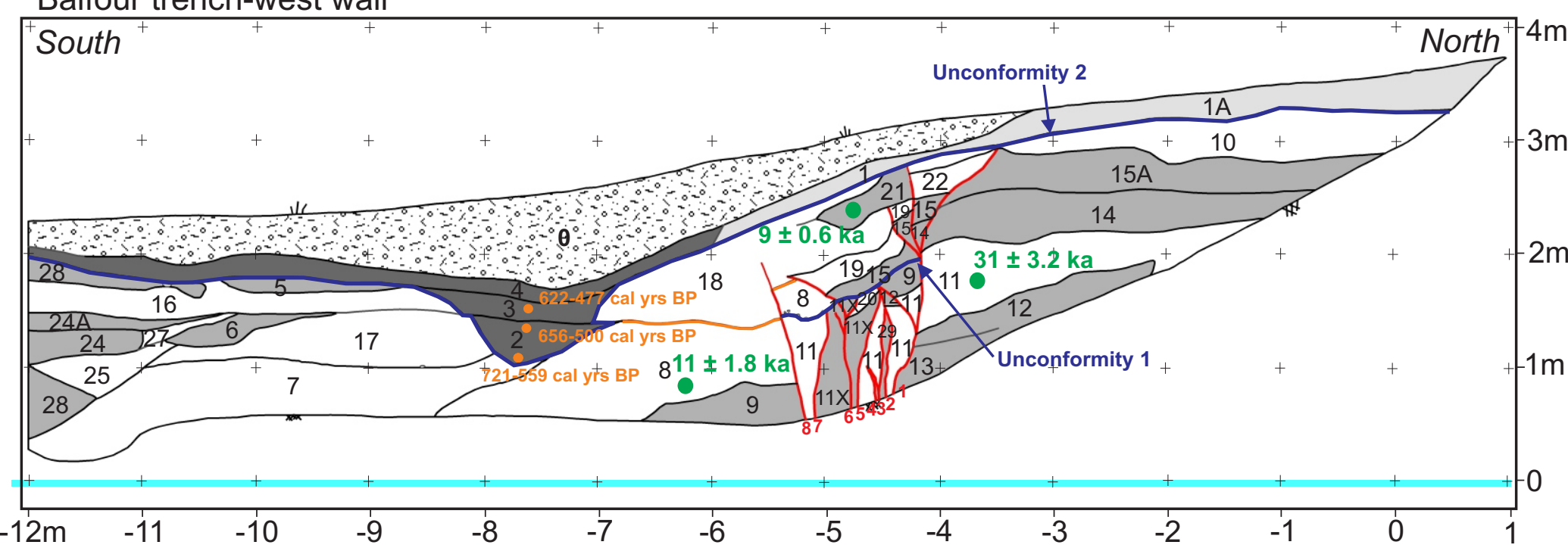

Balfour trench-east wall

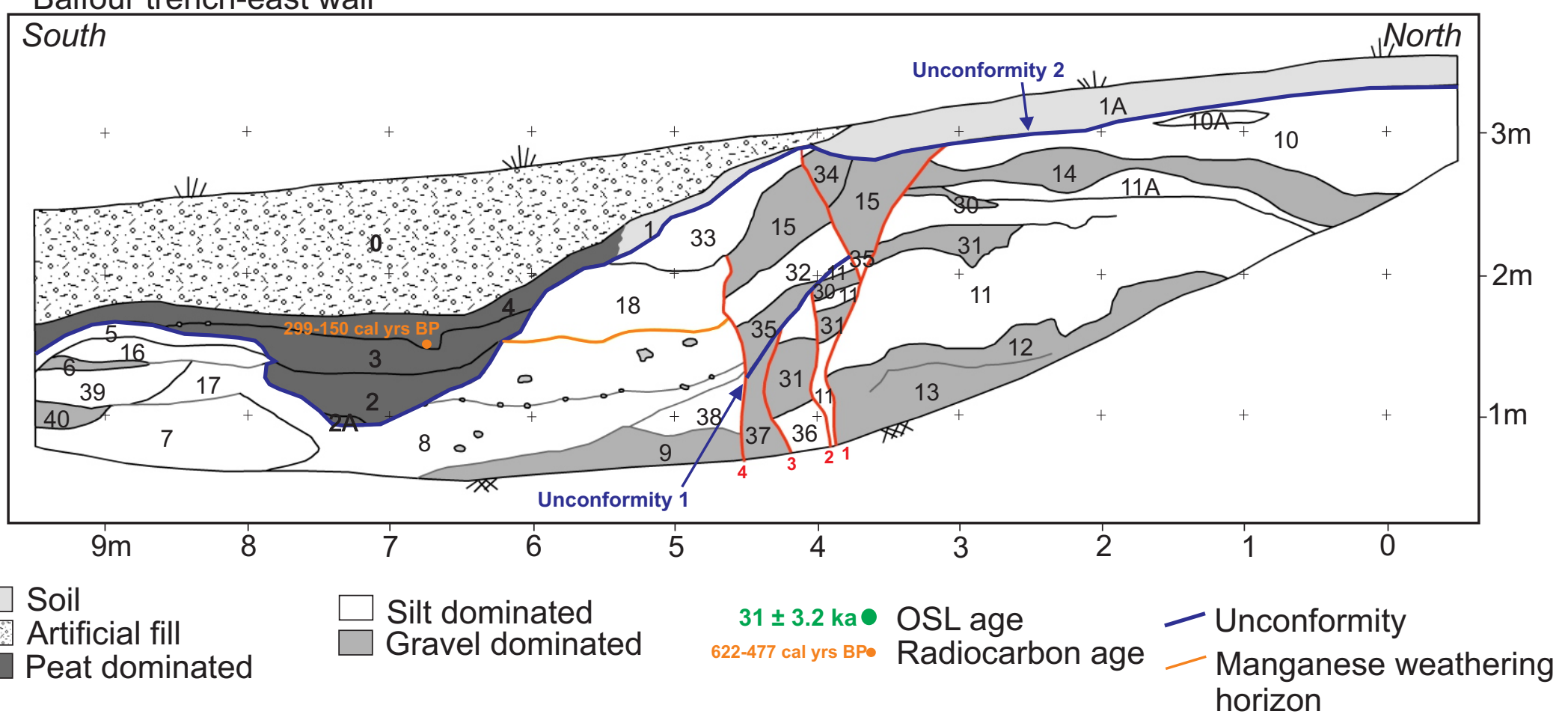


unit 11 , interpreted as a coverbeed of th terrace gravels of units 12,13 , equivalent to the $\sim 30 \mathrm{ka}$ Downs 2 terrace in the Awatere Valley [Eden, 1989; Little et al., 1998]. The equivalent loess coverbed and terrace gravels are not seen on the southern side of the fault zone in the trench, where the lowest silt (unit 8) has an OSL age of $11 \pm 1.8$ ka (Sample Balfour 5; Fig. 8). On the southern side of the fault zone, lenses of fluvial gravel and sands were probably deposited by the alluvial fan from Homestead Stream (Fig. 6). Units 2, 2A, 3, and 4 are peats to dark brown organic silts and contain scattered charcoal fragments and gravel clasts (Fig. 8). Radiocarbon dates on charcoal fragments in the peat units $(1,2$ and 3$)$ in the southern end of the trench are all radiocarbon dated at $<721$ cal. yrs BP (Fig. 8). These units are much younger than the underlying unit 8 and 18 (11-9 ka), are unconformable, and possibly deposited in a relict channel. About $1 \mathrm{~m}$ of anthropogenic fill (unit 0 ) has been emplaced artificially on the southern side of the fault in both trench walls. No units displaced by the fault can be traced across the fault zone (Fig. 8). The fault zone contains multiple sub vertical strands (eight on the west wall, four on the east wall) that are numbered on each wall (the numbering does not correlate on the two walls). Some of the faults also bifurcate vertically within the trench into splays.

I interpret that at least three earthquakes are recorded in the trench. The oldest earthquake (earthquake III) identified in the trench is indicated by the rupture of faults 1 (south splay), 2, 3, 5, 6 (north and south splay), and 7 in the west wall and the rupture of faults 2 and 3 in the east wall. These faults rupture up to unconformity 1 (Fig. 8). The earthquake probably also ruptured fault 8 , juxtaposing unit 11 against unit 8 on the west wall. I propose that unit 8 must have existed during the earthquake because it has acted as a buttress which unit 11 has been faulted against. On the west wall, I obtained an OSL age of $11 \pm 1.8 \mathrm{ka}$ in unit 8 , constraining a maximum age for the earthquake, whilst an OSL age of $9 \pm 0.6 \mathrm{ka}$ in unit 21 constrains a minimum age for the earthquake (Fig. 8). 
The penultimate earthquake (earthquake II) is constrained by the age of a co-seismic or post-seismic colluvial wedge on the western wall (Fig. 8). The earthquake ruptured faults 1 ( $^{\text {nd }}$ south splay), 6 , and 8 on the western wall and faults 1 (south and north splay) and 4 on the eastern wall. It faulted units 8,15 , and 19 on the western wall and units 32,35 and 15 on the eastern wall. On the western wall, fault 1 (second south splay) terminates at the base of a wedge of pebbly silt which I interpret to be a colluvial wedge, with an OSL age of $9 \pm 0.6 \mathrm{ka}$ (Fig. 8). Here the faults were identified as rupturing during earthquake II because they terminate at unit 21 or within unit 18 (within which the colluvial wedge interfingers). Unit 33 is a colluvial wedge equivalent to unit 21 on the west wall, covering the tips of the right splay of fault 1 and fault 4 . Here unit 34 was deposited in the wedge created by down-throw of the top of unit 15. Therefore the OSL age of $9 \pm 0.6 \mathrm{ka}$ in unit 21 (Fig. 8) on the western wall approximately constrains the timing of earthquake.

The last earthquake (earthquake I) is constrained as being younger than an OSL age of $9 \pm 0.6 \mathrm{ka}$ from the west wall (Fig. 8). This event ruptured the middle splay of fault 1 on the western wall and the south splay of fault 1 on the eastern wall. The north splay of fault 1 on the western wall and the north splay of fault 1 on the eastern wall may have ruptured to the topsoil. Fault 1 (middle splay) on the western wall faulted the colluvial wedge unit 21 and fault 1 (south splay) on the eastern wall faulted the lower contact of unit 33 (Fig. 8). Since fault 1 (middle splay) truncates unit 21 on the western wall, the earthquake occurred after $9 \pm 0.6 \mathrm{ka}$.

It is possible that more than one earthquake has ruptured on fault 1 (middle and north splay) on the west wall and fault 1 on the east wall. This is because the faults terminate at unconformity 2 , where there is a possible 8000 year hiatus between the $\sim 9$ ka OSL age in the colluvial wedge and a 
radiocarbon age of $\sim 560-700$ years in organic clay deposited in a stream channel. Hence the erosional unconformity 2 may have eroded evidence of younger earthquakes away.

Figure 9 a-e) Interpreted TAN0510 boomer seismic lines 2, 3, 5, 7, and 10 (see Fig. 1) with vertical exaggeration of 32. All the lines apart from line 3 were used for earthquake analysis. The translucent yellow areas show post-seismic growth sequences. On the left of the growth sequences, the respective earthquake identified and approximate age displayed. The coloured reflectors provide the age constraint in the profiles, with their approximate ages displayed. f) Vertical displacement-age plots of all of the seismic lines used for paleoseismic work offshore. The fault growth sequences are the 'ramps' in the data. For more information see Appendix D1. 
9 a)

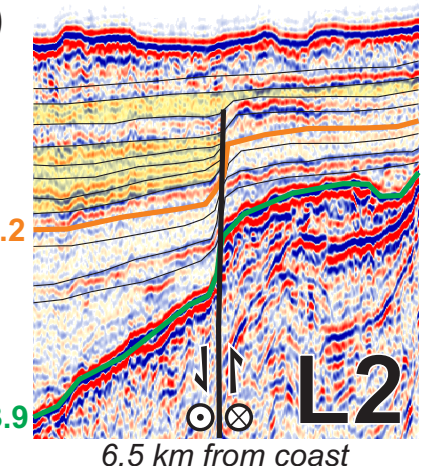

$6.5 \mathrm{~km}$ from coast Big Lagoon section

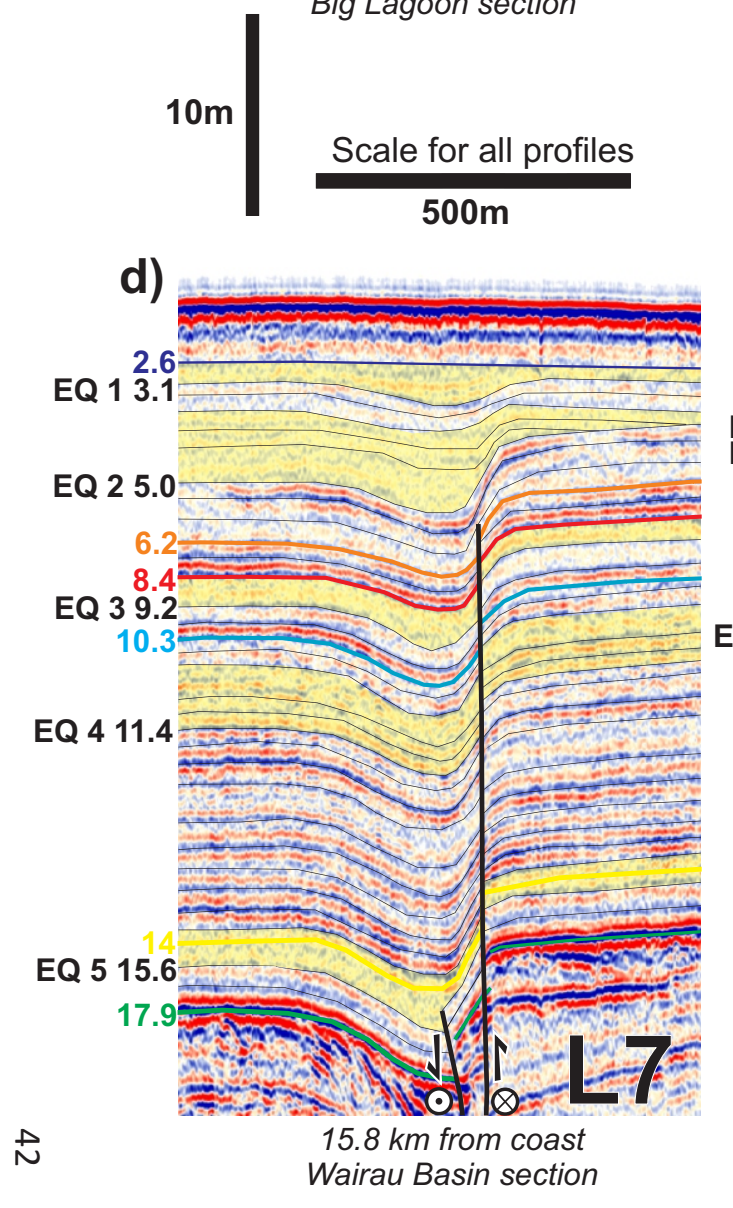

b)
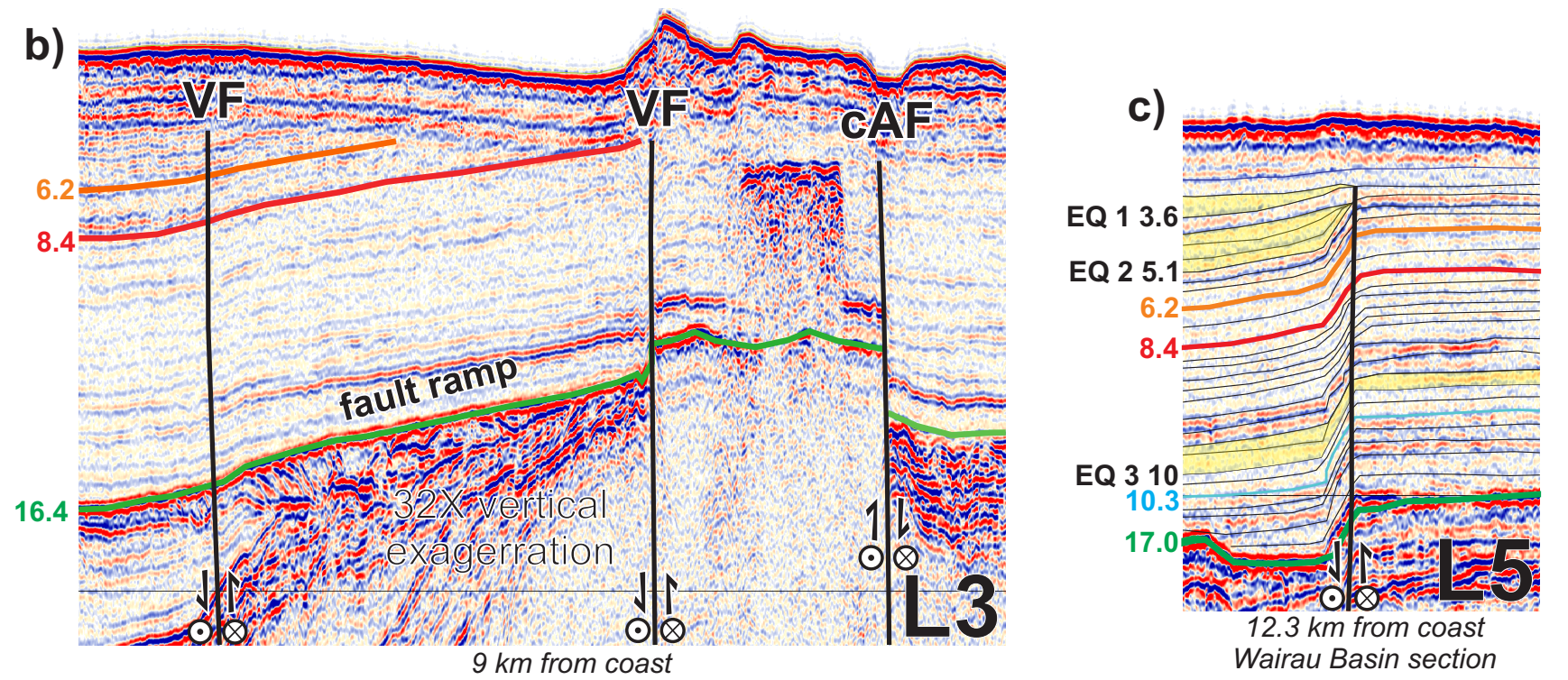

-

16.4 sos

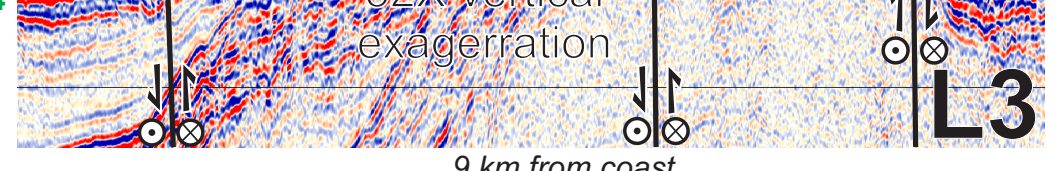

$9 \mathrm{~km}$ from coast

e)

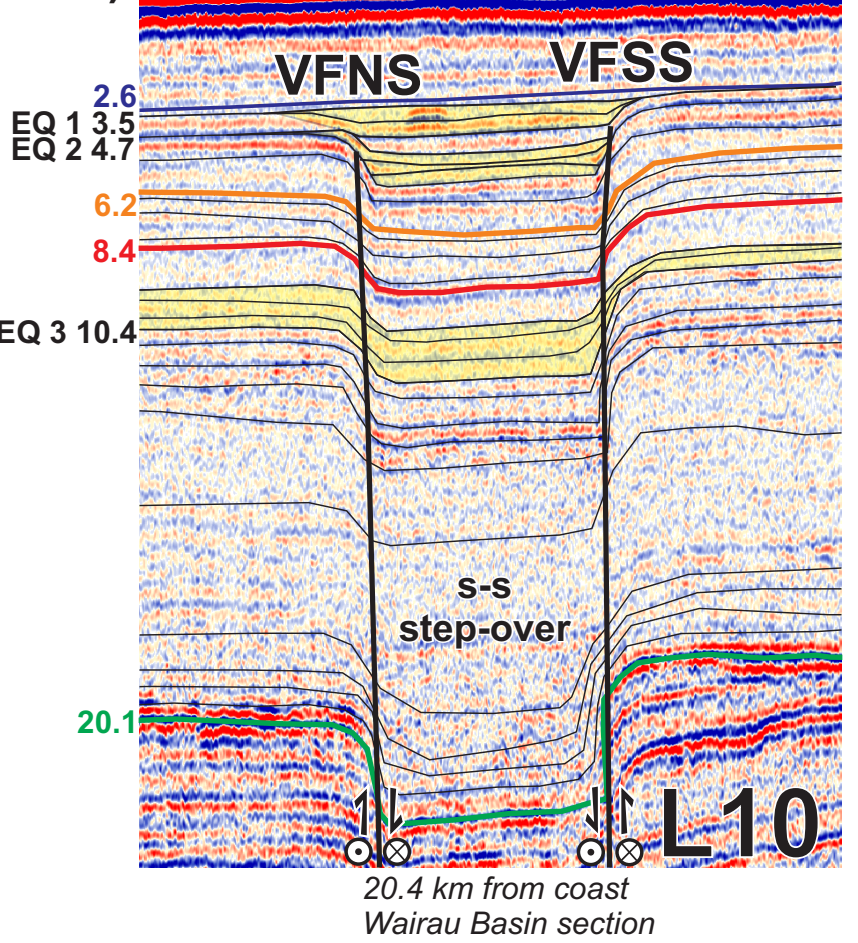

f)

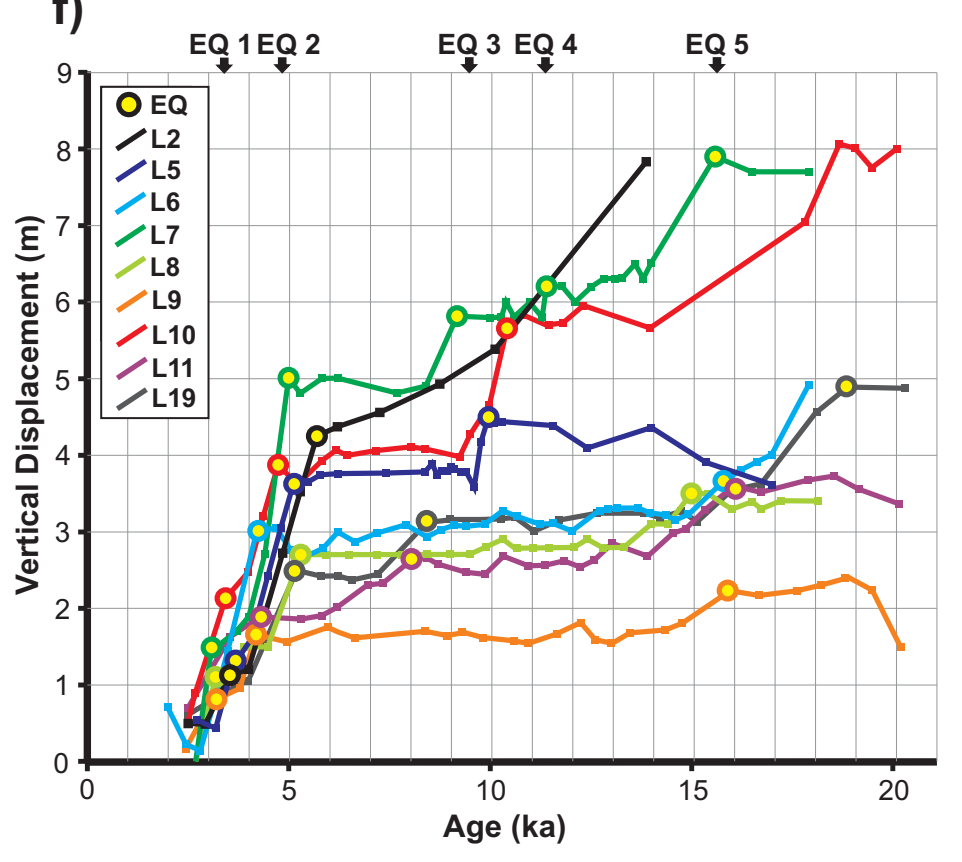




\subsubsection{Offshore Paleoseismic Record}

The Marlborough faults are crustal structures that accumulate elastic strain and don't creep aseismically [e.g., Stirling et al., 2012], and are in contrast to gravity-driven faults for which vertical displacement may be continuous over a variety of time intervals [Castelltort et al. 2004; Pochat et al., 2009]. Therefore, all of the vertical displacement observed in the seismic profiles of the Vernon Fault is the sum of co-seismic displacements and any potential post-seismic slip that may last weeks to years after large magnitude earthquakes [Barnes and Pondard, 2010]. The boomer profiles across the Vernon Fault reveal up to $6.2 \mathrm{~m}$ of total vertical displacement on the Wairau Basin section since formation of the PGS2/1 erosion surface. Our detailed analysis of the post-last glacial vertical displacement history in lines 2, 5-6, 9-12, and 19 (Fig. 1), provides results that are in close agreement with previous analysis of lines 7 and 8 [Pondard and Barnes, 2010] (Figs. 9a-e, 10). The profiles reveal post-seismic fault growth intervals (shaded yellow on Figs. 9a-e) that developed in response to continuous but not necessarily constant-rate sedimentation and burial of fault scarp topography, and intervening uniformly thick sequences that were deposited after complete burial of the tectonic topography and resumption of a near-flat depositional surface. The growth intervals have the sedimentary architecture of Type 1 post-seismic growth intervals of Barnes and Pondard [2010], indicative of sedimentation largely from water column settling rather than tractional processes (Appendix D1). The vertical displacement-time curves taken from the Vernon Fault are strongly stepped (e.g., Fig. 9f) and scarp-forming earthquakes are recognisable at the top of the inclined sections of the displacement-time curves (corresponding to the base of the post-seismic sequences on the seismic profiles) [Pondard and Barnes, 2010]. 
Because the post glacial sediments are thickest $(\sim 30 \mathrm{~m})$ beneath the mid-shelf in $60-80 \mathrm{~m}$ water depth, lines 7 and 8 preserve the highest temporal resolution in the stratigraphy, and consequently were the focus of the paleoearthquake analysis by Pondard and Barnes [2010]. Collectively, up to five paleoearthquakes are confirmed by scarp-forming ruptures associated with vertical displacements $>0.4 \mathrm{~m}$ (Figs. 9 and 10). Not all of the displacement events are recognisable on all of the profiles. An event may not be preserved at a certain location due to vertical throw being lower than the seismic resolution $(\sim 0.4 \mathrm{~m})$ or where successive post-seismic growth intervals were not stratigraphically separated as a result of insufficient sedimentation rate [Barnes and Pondard, 2010].

Earthquake 1 is preserved in lines 5, 8, 7, 9 and 10, and has a mean age of $3.3 \pm 0.7 \mathrm{ka}$ (Fig. 10), whilst earthquake 2 is preserved in lines $5,6,7,8,9,10,11$ and 12 , and has a mean age of $4.8 \pm 0.6$ ka. These two earthquakes are younger than the regional orange coloured reflector inferred to be $6.2 \pm 1.1 \mathrm{ka}$ (Fig. 9a-e). Despite the short recurrence interval ( 1.5 ka) between them, a thin uniformily-thick sequence represented by one or two reflectors was deposited between the two post-seismic growth intervals, indicating burial of the fault scarp (eg. Fig. 10). In line 10 the growth sequence from earthquake 1 interrupts the growth sequence from earthquake 2 , indicating that at this location the scarp created by earthquake 2 had not been completely infilled before earthquake 1 occurred (Fig. 9e). Where sedimentation was sufficient to completely bury the fault scarp between successive earthquakes, the coseismic vertical displacement is equivalent to the height of the inclined risers on the displacement history curves [Barnes and Pondard, 2010]. Earthquake 1 exhibits equal or less vertical displacement than earthquake 2 , with means of $1.2 \mathrm{~m}$ and $1.9 \mathrm{~m}$, respectively (Fig. 10). 
Earthquakes 3, 4 and 5 have larger recurrence intervals and lower vertical displacements than earthquakes 1 and 2. Earthquake 3 is recognised in lines 5, 7, 10, 11 and 12 with a mean age of $9.2 \pm$ 1.4 ka (Fig. 10). In lines 5, 7 and 10 the post-seismic growth sequences are below our interpreted picking of the red reflector $(8.4 \pm 1.6 \mathrm{ka})$ and in lines 11 and 19 they are above it. This discrepancy results in apparent earthquake ages 9.2-10.4 ka in lines 5, 7 and 10 and ages of 8.1-8.4 ka in lines 11 and 19. However, I consider this is probably a result of imperfect correlation of the red reflector and not two separate earthquakes as they are within error of each other. The vertical displacements for this earthquake range from 0.4-0.8 $\mathrm{m}$ and average $0.6 \mathrm{~m}$, ignoring line 10 as the displacement is anomalously high $(1.9 \mathrm{~m})$ across the extensional step-over (Fig. 1). Earthquake 4 had previously been interpreted tentatively in line 7 by Pondard and Barnes [2010], as a $0.4 \mathrm{~m}$ vertical growth increment commencing at $11.4 \pm 3.3$ ka (Figs. 9d, 10). I have not recognised this growth interval on any other profiles, suggesting the event either is an outlier, or a rupture associated with a very small vertical displacement and resolved only at this location. Earthquake 5 is preserved in lines $6,7,8,9$, and 11 , with a mean age of $15.6 \pm 2.4 \mathrm{ka}$. The vertical displacement associated with this earthquake averages $\sim 0.7 \mathrm{~m}$ and the range is $0.3-1.7 \mathrm{~m}$. Fault vertical growth of up to $1.7 \mathrm{~m}$ is possible from $\sim 18.8-15.1 \mathrm{ka}$ on line 10, but this tentative observation was not included in the analysis shown on Fig. 10. 
Vernon Fault submarine paleoearthquakes

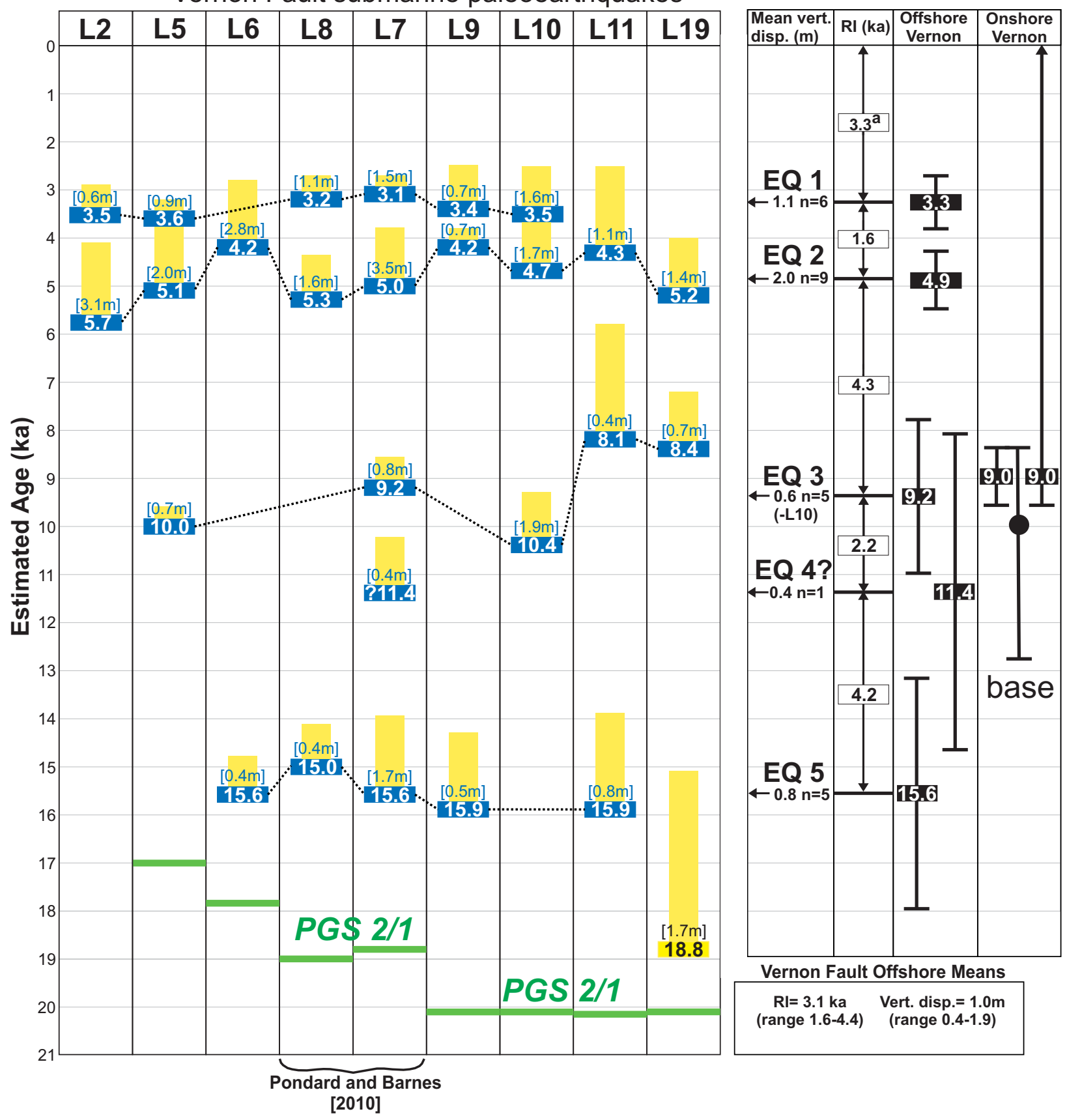

Figure 10) A summary and compilation of the paleoearthquakes found on each seismic line offshore. Recurrence interval (RI) and vertical displacements and mean age displayed for the offshore paleoseismic record (Including EQ 4). The onshore trench record from this study and Clark et al., [2011b] is also presented. Uncertainties in the timing of offshore and onshore paleoearthquakes are to $95 \%$ confidence. 


\subsection{Discussion}

\subsubsection{Slip rates and Kinematics of the Vernon Fault}

The maximum slip rate of $4.9 \mathrm{~mm} / \mathrm{yr}$ on the Vernon Fault at Homestead Stream may, in fact, be too high. The paleoseismic derived mean recurrence interval of $3.1 \mathrm{ka}$ from the offshore data would require an average dextral offset of $\sim 12.6 \mathrm{~m}$ per earthquake to accumulate $122 \mathrm{~m}$ of dextral offset in 30 ka (3.1 ka x $4.1 \mathrm{~m} / \mathrm{ka}(\mathrm{mm} / \mathrm{yr})=12.6 \mathrm{~m})$ [Clark et al., 2011b]. Unless larger composite earthquakes simultaneously rupture parts of the Awatere, Vernon and Cloudy faults and produce very large surface displacements [Stirling et al., 2012], the required coseismic displacement on the Vernon Fault seems anomalously high based on fault scaling relationships [Wells and Coppersmith, 1994, Stirling et al., 2012] and the small stream offsets observed. Considering the Vernon Fault is $\sim 40 \mathrm{~km}$ in length, scaling relationships indicate probable single event displacements of $\sim 2 \mathrm{~m}$ for individual ruptures on the fault. If the Vernon Fault has coseismic dextral displacements of more than $2 \mathrm{~m}$, when combined with the mean recurrence interval it would result in a slip rate of $>0.7$ $\mathrm{mm} / \mathrm{yr}$, which I consider very likely (e.g. sites 2, 35, Figs. 2a,c). In comparison, less than $1 \mathrm{~km}$ southeast of Homestead stream in the Big Lagoon section there are two offset streams that are dextrally displaced by $8 \pm 2 \mathrm{~m}$ at site 39 , and $3.3 \pm 2.4 \mathrm{~m}$ at site 41 (Fig. 3c, Table 1). Possible single event dextral displacements of as little as $\sim 4 \mathrm{~m}$ at one site lead to dextral slip rates of $>1.3 \mathrm{~mm} / \mathrm{yr}$. These data indicate that the strike-slip rate is lower or the recurrence interval is lower than what has been measured. It is possible the recurrence interval could be lower, as there could be earthquakes unrecognised or missing from the present paleoseismic records (e.g., [Barnes and Pondard, 2010]) but a lower slip rate is more viable as a maximum rate was measured at Homestead Stream (site 43, Fig. 3c, Table 1). 
Simple kinematic addition requires that the dextral slip rate on the Vernon Fault must equal the slip rate lost from the Awatere Fault across the bifurcation of the Vernon Fault minus any slip that is accommodated by internal deformation of the Vernon Block (between the Vernon and coastal Awatere faults, Fig. 1) [Little et al., 1998; Benson, 2000]. Prior to this study the Vernon Fault had been estimated to have a dextral displacement rate of $<4.5 \mathrm{~mm} / \mathrm{yr}$ based on the reduction of slip rate from $\sim 6 \mathrm{~mm} / \mathrm{yr}$ [Benson et al., 2001] to $>1.5 \mathrm{~mm} / \mathrm{yr}$ [Little et al., 1998] on the Awatere Fault north eastwards across the intersection with the Vernon Fault. The slip rate on the coastal Awatere Fault near the coast has recently been measured as $\sim 1 \mathrm{~mm} / \mathrm{yr}$ [Chapter 1 , this thesis]. I measured a maximum dextral slip rate of $4.9 \mathrm{~mm} / \mathrm{yr}$ on the Vernon Fault near Big Lagoon (site 43, Fig. 2c). The dextral-displacement rate of $1.5 \pm 0.3 \mathrm{~mm} / \mathrm{yr}$ on the Flaxey splay provides a minimum rate of dextral slip on the Vernon Fault. These data collectively imply that $6 \pm 1 \mathrm{~mm} / \mathrm{yr}$ of slip comes from the eastern Awatere Fault southwest of the Dumgree splay junction, and 2.6-5.9 mm/yr of slip is measured on the Vernon and coastal Awatere faults combined, indicating a possible slip-rate shortfall. Any shortfall would require additional slip on hidden faults, pervasive shearing, and/or vertical axis rotation of the Vernon Block [Little et al., 1998] (see discussion below).

Any slip rate deficit across the Vernon, coastal Awatere, and Cloudy faults require the presence of off-fault deformation. Off fault deformation is apparent by comparing the fault net slip vectors to the Pac-Aus relative plate motion vector. Although sections of the Vernon Fault range in strike from $000^{\circ}$ (Dumgree splay at site 3, Fig. 3a) to $090^{\circ}$ (offshore Wairau basin), it always has a predominant dextral component, with variations in a subordinate reverse component. Fault net slip azimuths estimated on the Vernon Fault offshore (and possibly in the Vernon Hills) are misaligned with respect to the Pacific-Australian (Pac-Aus) relative plate motion vector. Off-fault deformation must be accommodating a component of the Pac-Aus relative plate motion, causing the fault net slip azimuth to be non-parallel with the Pac-Aus plate motion vector. Therefore the kinematic 
a)

b)
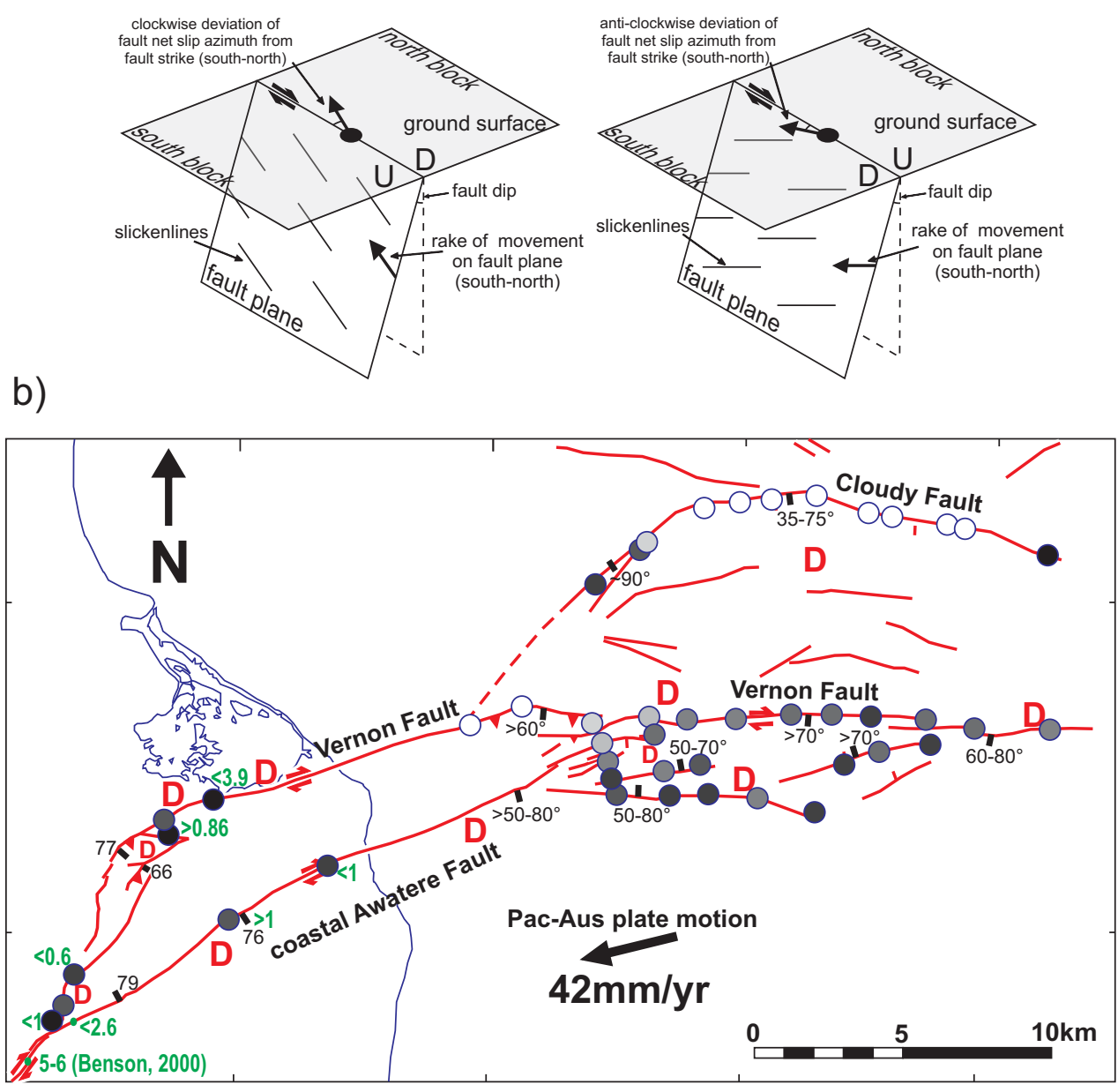

Vert. disp. rate ( $\mathrm{mm} / \mathrm{yr})$

$0.6+$

0.5-0.6

$0.4-0.5$

0.3-0.4

$0.2-0.3$

$0.15-0.2$

$0.1-0.15$

0.05-0.1

$<0.05$

Strike Slip rate

(mm/yr)

0.1

Fault, dip direction

c) and dip of fault

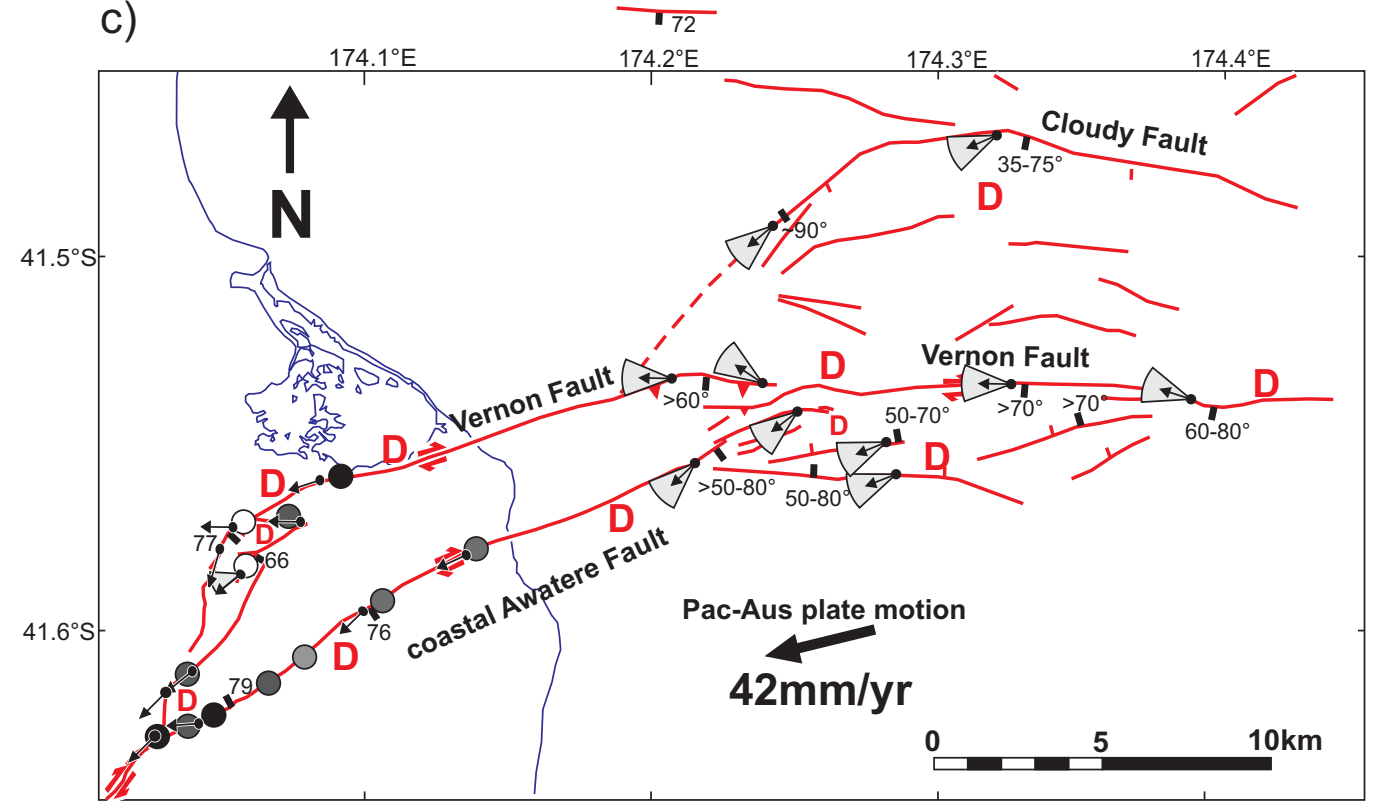

$\mathrm{H} / \mathrm{V}$ ratio

$\bigcirc<2$

2-3

3-4

4-6

6-8

8-10

$10-20$

$>20$

Fault net slip azimuth (southern block-northern block)

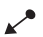

Quadrant containing fault net slip azimuth

(southern block-northern block) A

Figure 11a) Schematic diagram of the relationship between the normal/reverse component of dextral faulting and the fault net slip azimuth. b) Map showing slip rate data. Both maps display fault geometry and sense of strike slip and throw. c) Map showing fault displacement data with $\mathrm{H} / \mathrm{V}$ ratios, and inferred fault net slip azimuths. The inferred fault net slip azimuth is based on approximate estimates of fault dip and dip slip rates. Coastal Awatere fault neotectonic data and Cloudy fault dip is from Chapter 2, [this thesis]; Cloudy fault vertical displacement rate data is from Pondard and Barnes, [2010]. 
complexity of the Vernon Fault along strike cannot be understood in terms of rigid blocks translating parallel to plate motion. This misalignment is most prominent offshore where the strike of the Vernon Fault swings to $\sim 270^{\circ}$, an orientation in which you would expect a normal faulting as the relative plate motion is clockwise of the strike of the fault. However, strike slip faulting with a reverse component occurs on this section with fault net slip azimuth $\sim 15-70^{\circ}$ clockwise of the PacAus relative plate azimuth (Fig. 11b). Pondard and Barnes [2010] demonstrated that there is extension across the Wairau Basin north of the Vernon Fault, accommodated by the Cloudy and offshore Wairau faults. The overlap of the Big Lagoon and Wairau Basin sections, close to the convergence with the Cloudy and coastal Awatere faults, is characterised by a larger reverse component with higher vertical rates and possibly shallower fault dip than on the Wairau Basin section further east. This probably results in increased clockwise fault net slip azimuth deviation from the Pac-Aus relative plate motion vector (Fig. 11b). The fault net slip azimuth on the part of the Vernon Fault adjacent to Big Lagoon section is parallel with the Pac-Aus relative plate motion vector (Fig. 3c). The Vernon Hills section should have a strong reverse sense as the splays strike mainly $000^{\circ}-045^{\circ}$, in a restraining orientation relative to both the Pac-Aus relative plate vector and the Awatere Fault (Fig. 11b). Our data confirm a larger reverse component in these splays than on the Big Lagoon section, with six of the seven net slip azimuths within $15^{\circ}$ of the Pac-Aus plate motion vector. The fault slip vectors in the Vernon Hills are therefore parallel to slightly clockwise of the relative plate motion vector. Vertical-axis rotation of the Vernon block and the Cloudy block (between the Vernon and Cloudy faults) relative to their surroundings could in part cause the deviation of the fault slip vectors compared to the relative plate motion vector along the length of the Vernon fault [Chapter 2, this thesis].

In the Vernon Hills, multiple splays of the Vernon fault have low slip rates $(<1.6 \mathrm{~mm} / \mathrm{yr})$ compared to the slip rate adjacent to Big Lagoon, creating a possible slip deficit on the splays in the Vernon 
Hills. The slip deficit is mainly convergence [Chapter 2, this thesis] and must be accommodated by a combination of slip on unsighted splays in the Vernon Hills and other off fault deformation. The offfault deformation is at a smaller scale than the rotation of the Vernon and Cloudy blocks and may include: 1) vertical axis rotations of splay bounded blocks in the Vernon Hills that are propelled by the larger Vernon block rotation with respect to the rocks to the west of the splays, and/or 2) uplift of the Vernon Hills to the west of the Vernon fault splays by unsighted reverse fault structures [Chapter 2, this thesis]. Both of these off-fault deformations can explain the lack of convergence and a stronger strike-slip component on the splays within the Vernon Hills.

\subsubsection{Implications for subsidence of Big Lagoon}

Tectonic subsidence and eustatic sea-level rise has resulted in the accumulation of $>8 \mathrm{~m}$ of estuarine deposits in Big Lagoon during the Holocene [Clark et al., 2011 ${ }^{\mathrm{a}}$ ]. Analysis of the depositional environments and dating of shells within intertidal sands, silts and muds indicates subsidence rates of $0.2-0.8 \mathrm{~mm} / \mathrm{yr}$ (typically $\sim 0.55 \mathrm{~mm} / \mathrm{yr}$ ) along the $\mathrm{SW}$ margin of the lagoon. Whilst the cause of the Holocene subsidence was inferred by Clark et al. [2011a] to be permanent tectonic deformation, it could not be determined if the subsidence was gradual or coseismic. Historical evidence exists of subsidence in the lower Wairau Valley and Big Lagoon following the 1848 earthquake on the Awatere Fault and the 1855 earthquake on the Wairarapa Fault [Grapes and Downes, 1997], however, on both occurrences it has been concluded that no widespread subsidence was reported [Grapes and Downes, 1997; Hayward et al., 2010; Clark et al., 2011a]. The Wairarapa Fault, together with the Awatere, Wairau, and Cloudy faults may be too far away to be considered as viable sources of the tectonic subsidence, moreover their motion, excluding the Cloudy Fault, is chiefly strike slip. If the Holocene subsidence of Big Lagoon is coseismic, the two most likely faults responsible are the 


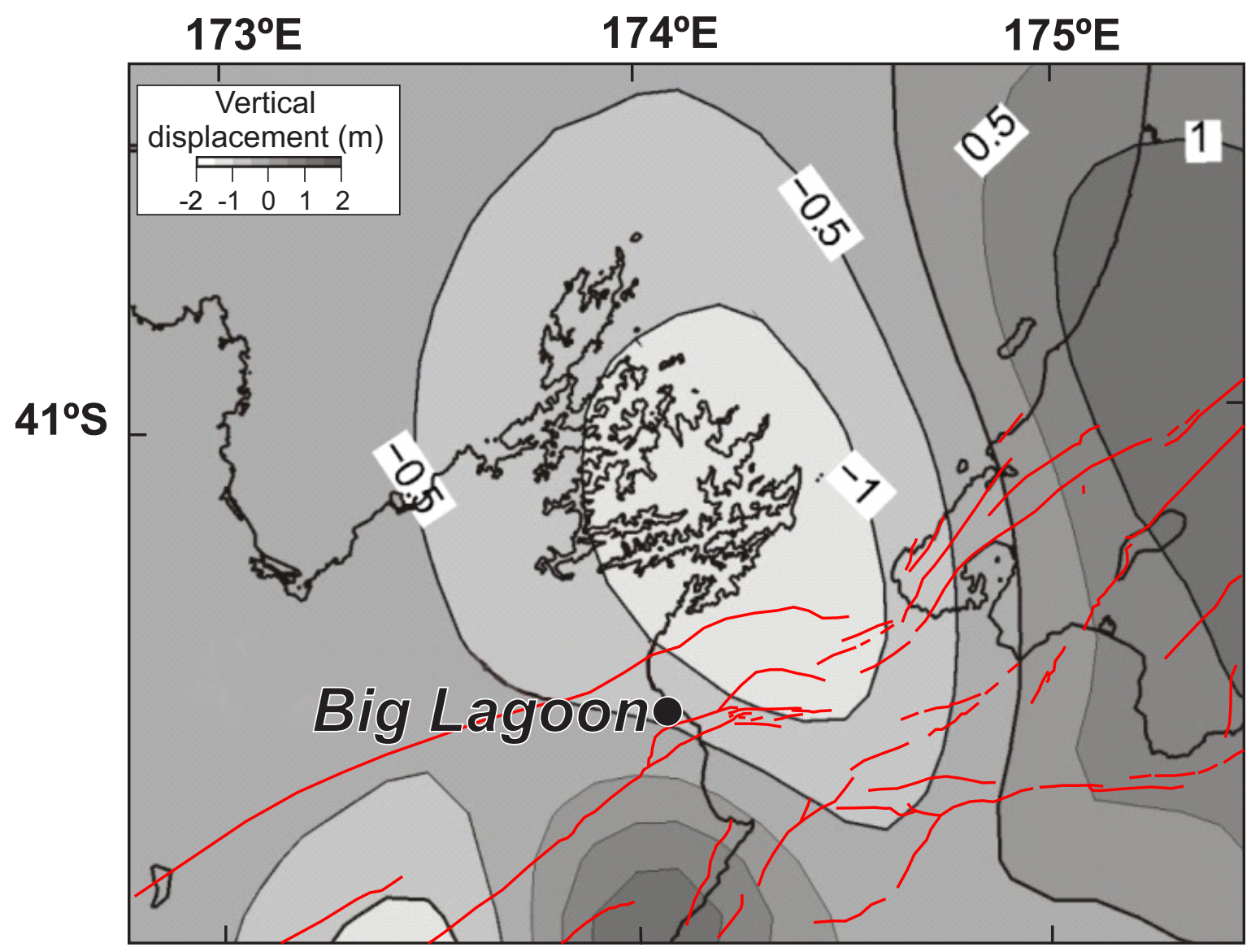

Figure 12) Map of surface vertical coseismic displacement elastically modeled to occur in a 1 in 500 year earthquake on the Hikurangi subduction interface. Source Laura Wallace, GNS Science as published in Clark et al., [2011b]. 
Hikurangi subduction thrust and/or the Vernon Fault [Clark et al., 2011a]. During subduction earthquakes, such coseismic subsidence may occur in the upper plate of subduction zones (Fig 12), as has been observed on the Cascadia Margin [Leonard et al. 2004], Sumatran Margin [Zachariasen et al. 2000] and the northern part of the Hikurangi Margin [Cochran et al. 2006]. In these studies coseismic deformation is expressed by a regional zone of subsidence above the down dip end of the rupture patch.

The local geometry and sense of slip on the Vernon Fault will determine the potential contribution of the fault to the subsidence of Big Lagoon. The geomorphology of the fault trace, south-dipping geometry, vertical and dextral displacements, and seismic data indicate the fault near Big Lagoon is predominantly strike-slip with a reverse component that appears to increase towards the immediate offshore. With the highest observed dip slip rates of $<0.14 \mathrm{~mm} / \mathrm{yr}$ at Flaxey Gulley, this part of the fault can account for no more than $25 \%$ of the $\sim 0.55 \mathrm{~mm} / \mathrm{yr}$ of Big Lagoon subsidence [Clark et al., 2011b], even if all the dip-slip displacement causes a corresponding subsidence of the northern block relative to sea level, which is highly unlikely due to the fault's dextral-reverse sense [Jackson et al., 1988; McAlpin, 2009]. However, the fault trace immediately adjacent to Big Lagoon is not exposed and could lie south of the Balfour trench site (Fig. 6), and immediately offshore the vertical displacement rate is $0.6-0.9 \mathrm{~mm} / \mathrm{yr}$ (Fig. $7 \mathrm{~b}$ ). It seems probable therefore, that oblique slip on the Vernon Fault near the coast accounts for $<25 \%$ of the subsidence at Big Lagoon, but that the majority of subsidence may be related to Hikurangi subduction earthquakes [Clark et al., 2011b]. 


\subsubsection{Onshore-offshore paleoseismic correlations on the Vernon Fault: Implications for hazard and fault interactions}

Either of the last two earthquakes in the offshore record could correlate to the last earthquake identified in the Balfour trench (Fig. 10). One of these offshore earthquakes may not be preserved in the trench because of (1) the $\sim 8000$ year hiatus in deposition at the trench site, at unconformity 2 (Fig. 8), (2) the rupture did not extend onshore $15 \mathrm{~km}$ to the trench location, or (3) the fault ruptured beneath the base of the hill-slope $\sim 70 \mathrm{~m}$ south of the trench (Fig. 2c, 6). The latter scenario, in which the rupture may have occurred on the southern strand of a pull apart step-over in the Vernon Fault, would be analogous to rupture on one strand of the Wairarapa Fault in 1855 [Little et al., 2009]. It is also possible that the fault trace at the Balfour trench did not rupture during an earthquake offshore, however, two offshore earthquakes are inferred to postdate $6.2 \pm 1.1$ ka on seismic line 2 (Figs. 1, 9a, 10) on the eastern end of the Big Lagoon section. 

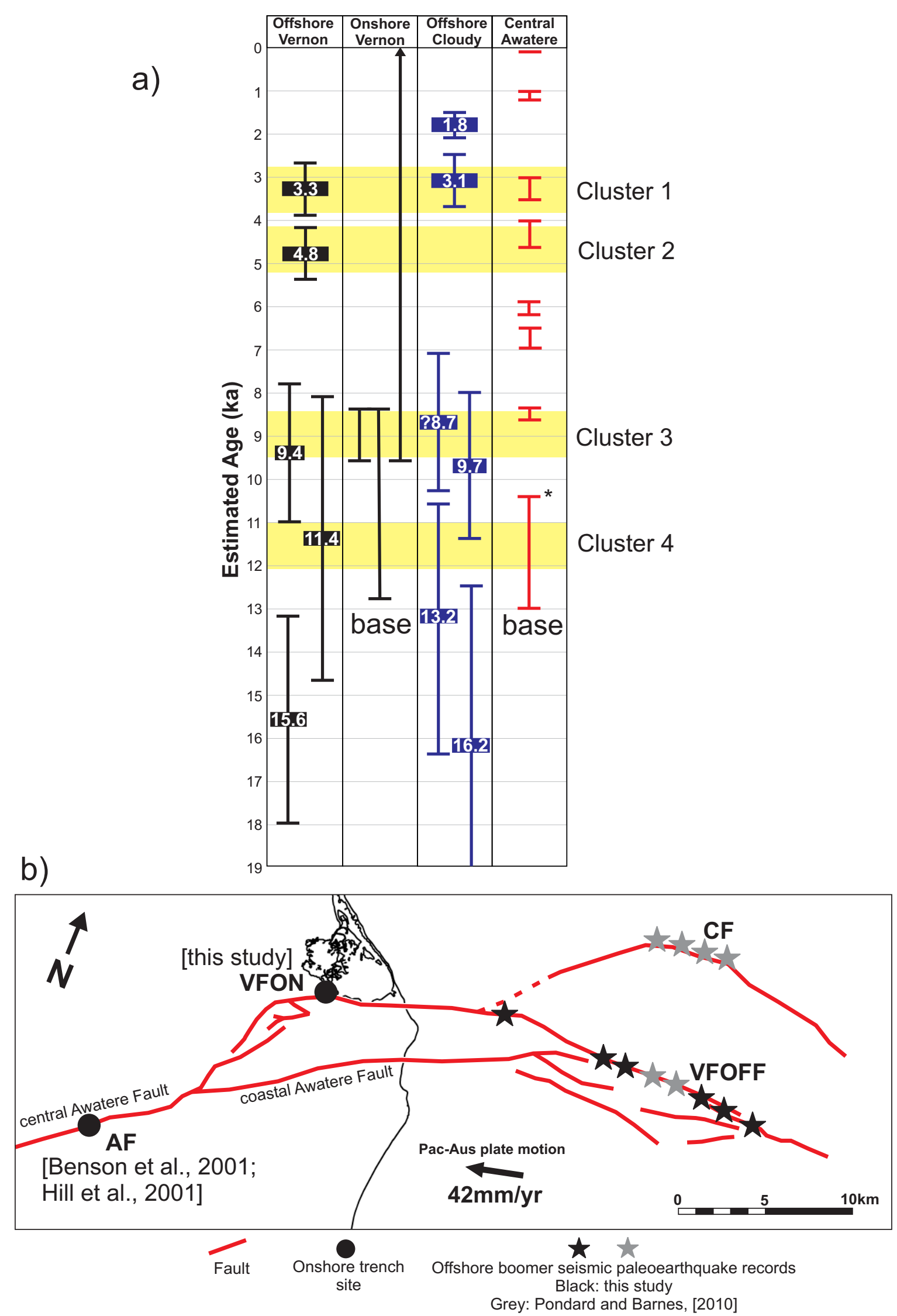

Figure 13 a) Timeline showing approximate timing of paleo-earthquakes on the Vernon (VFON and VFOFF), cental Awatere (AF), and Cloudy (CF) faults since 19 ka, [Benson et al., 2001; Hill et al., 2001; Pondard and Barnes, 2010].On the Vernon fault offshore the paleoearthquakes are interpreted from seven seismic profiles and on the Cloudy fault they are interpreted from 4 profiles [Pondard and Barnes, 2010]. The yellow zones show temporal clusters of earthquakes on the three faults. Uncertainties in the timing of paleoearthquakes is to 95\% confidence. b) Map showing location of paleoseismic studies undertaken on the Vernon, Awatere, and Cloudy faults. ${ }^{*}$ From Mason, [2006] Saxton-2 trench on the central Awatere fault $\sim 90 \mathrm{~km}$ southeast of Dumgree splay. 
Up to three earthquakes older than 9 ka have been identified on the fault, two of them correlating across the onshore and offshore records. Earthquake II from the trench $(9 \pm 0.6 \mathrm{ka})$ is within error of Earthquake 3 offshore (Fig. 10), which occurred at $9.4 \pm 1.4$ ka. Earthquake 3 is well constrained in 5 seismic lines which vary in age from 8.1-10.4 ka. Earthquake III ( 9-11 ka) in the trench is within error of Earthquake $4(11.4 \pm 3.3 \mathrm{ka})$ in the offshore record, although the latter is identified tentatively only in line 7 [Pondard and Barnes, 2010], (Fig. 9). The mean recurrence interval is $3.7 \pm$ 0.6 kyrs in the Balfour trench [Clark et al., 2011b] and $3.1 \pm 0.7$ kyrs offshore. Considering the elapsed time since the last earthquake offshore, and the variability in recurrence interval $\mathrm{RI}$, the fault appears to be $75-100 \%$ through its seismic cycle [Pondard and Barnes, 2010]. This is of importance to the township of Blenheim, $8 \mathrm{~km}$ to the west, and possibly to Wellington City, $40 \mathrm{~km}$ to the northeast, concerning seismic hazard.

Paleo-earthquakes on the Vernon, Awatere and Cloudy faults have occurred at similar times, with age uncertainties overlapping (Fig. 13) [Benson et al., 2001; Mason and Little., 2006; Pondard and Barnes, 2010; Clark et al., 2011b]. In the last 19 ka there have been three clusters in the dates of rupture on multiple faults within error of each other at $\sim 3.1-3.3 \mathrm{ka}, 4-5 \mathrm{ka}$, and 8.5-9.5 ka. A possible fourth cluster occurred at 11-12 ka. Every Cloudy and Vernon fault earthquake has occurred at similar times as an Awatere Fault earthquake apart from the $1.8 \pm 0.3$ ka event on the Cloudy Fault [Pondard and Barnes, 2010]. The overlapping paleoearthquake ages could be due to either multiple faults rupturing in the same event (as in the 1994 M7.3 Landers earthquake [Cohee and Beroza, 1994; Wald and Heaton, 1994]), or one earthquake triggering another within the error of the available dates (e.g. the North Anatolian Fault [Stein et al., 1997]). Such earthquake triggering may be related to the inhibitance of fault bends and junctions to earthquake propagation [Barka and Kadinsky-Cade, 1988], and subsequent changes in static stress in the surrounding crust [Robinson et al., 2010; Pondard and Barnes, 2010]. I cannot distinguish possible simultaneous rupture of multiple 
faults during large composite earthquakes, from stress triggered events, but I can assess the past patterns of earthquakes. Theeastern Awatere Fault has ruptured more often than the Vernon and Cloudy faults, with reccurrence intervals ranging from $\sim 600-1800$ years (mean $~ 1400$ years) [Benson et al., 2001] which is consistent with its higher slip rate. Before 2 ka only two of the six Awatere Fault earthquakes (5.9-6.2 ka and 6.5-6.8 ka) do not cluster with a Vernon Fault earthquake. Since 2 ka, two earthquakes (1-1.2 ka and the 1848 Marlborough Earthquake) have occurred on the Awatere Fault without Vernon Fault or Cloudy Fault rupture. Pondard and Barnes [2010] demonstrated that that these recent earthquakes on the Awatere Fault have contributed to decreased Coulomb static stress on the onshore Wairau Fault, and increased static stress on the offshore Vernon and Cloudy faults, thus bringing the latter somewhat closer to rupture. 


\subsection{Conclusions}

Although splays of the Vernon fault range in strike from $\sim 000^{\circ}-090^{\circ}$, the fault is predominantly dextral with a subordinate reverse component along its entire length. The fault accommodates 1.5$4.9 \mathrm{~mm} / \mathrm{yr}$ of dextral slip, representing $25-120 \%$ of the $5 \pm 1 \mathrm{~mm} / \mathrm{yr}$ slip lost from the eastern Awatere Fault east of its bifurcation. Fault length scaling relationships indicate that the Vernon Fault should be slipping at $\sim 1.3 \mathrm{~mm} / \mathrm{yr}$ so the fault is either accommodating little of the slip lost across the Awatere Fault or the Vernon Fault is slipping anomalously fast at the minimum and maximum bounds of the measured slip rate. Any possible slip disparity is most likely accommodated by offfault deformation within the Vernon Hills block between the Vernon and Awatere faults.

Late Quaternary fault motion indicates that displacement through the large scale bending in the Vernon fault is strongly controlled by local deformation rather than large scale relative plate motion. The inferred fault net slip azimuths do not match the Australia-Pacific plate vector, indicating that off-fault deformation is accommodating components of the Pacific-Australian relative plate motion. The local deformation is most likely a combination of partitioned faulting, distributed deformation, and vertical axis rotations of the fault bounded blocks surrounded by the Vernon, Awatere, and Cloudy faults.

In the Vernon Hills, multiple splays of the Vernon fault have low slip rates $(<1.6 \mathrm{~mm} / \mathrm{yr})$ compared to a slip rate of $<4.9 \mathrm{~mm} / \mathrm{yr}$ adjacent to Big Lagoon, creating a possible slip deficit on the splays in the Vernon Hills. Any slip deficit may be accommodated by slip on unsighted splays in the Vernon 
Hills, vertical axis rotation of splay bounded blocks in sympathy to the larger Vernon block rotation, and uplift of the Vernon Hills to the west of the splays in the Vernon Hills.

Vertical displacement on the Vernon Fault adjacent to Big Lagoon is likely responsible for $>25 \%$ of the total Holocene subsidence of the lagoon. The remaining subsidence may result from southern Hikurangi subduction interface earthquakes.

Our offshore paleoseismic record derived from detailed analysis of vertical fault growth in highresolution seismic sections correlates well with previous offshore analyses and with an onshore record derived from a trench site. An earthquake in the offshore record may be missing from the onshore trench because of (1) the $\sim 8000$ year hiatus at the trench site, (2) rupture did not extend onshore $15 \mathrm{~km}$ to the trench location, or (3) fault ruptured beneath the base of the Big lagoon hillslope $\sim 70 \mathrm{~m}$ south of the trench. The recurrence interval for the Vernon Fault is $\sim 3-4 \mathrm{ka}$ and at least the offshore section last ruptured at $3.3 \pm 0.6 \mathrm{ka}$. I confirm that paleo-earthquakes on the Vernon Fault were found to rupture at similar times to paleo-earthquakes on the Awatere and Cloudy faults over the last $12 \mathrm{ka}$. This could be due to simultaneous rupture of different faults or earthquakes triggered close in time by increased static stress changes. 
Chapter 2: Late Quaternary Kinematics and Late Cenozoic Evolution of the Coastal Awatere, Vernon and Cloudy Faults, Marlborough Fault System, New Zealand. 


\subsection{Abstract}

The NE part of the active Awatere fault zone in the Marlborough Fault System bifurcates eastward into several splays, some of which strike at up to $60^{\circ}$ to the main fault. These splays include the coastal Awatere, Vernon, and Cloudy faults, all of which are active, and the Fuchsia Fault further to the south, which is inactive. I evaluate the kinematic evolution of this intersecting fault network by measuring late Quaternary displacements on the four fault strands both onshore and offshore. Based on these data I reconstruct the relative positions of the blocks bounded by these faults backwards through time. The slip data are used to construct a conceptual model for how the fault network has evolved from a transition zone between the Marlborough Fault system (South Island) and the North Island Dextral Fault Belt (North Island), and the role of vertical axis rotation in that evolution. Onshore, Optically Stimulated Luminescence dating and tephrochronology provide age control for late Quaternary slip rate estimates. Offshore, seismic reflection data constrain fault structure and record vertical displacement rates affecting the post Last Glacial Maximum (LGM) sediments $(<20 \mathrm{ka})$. West of the point of fault strand bifurcation, the eastern Awatere Fault slips at 6 $\pm 1 \mathrm{~mm} / \mathrm{yr}$. East of that point, the coastal Awatere Fault accommodates $\sim 1 \mathrm{~mm} / \mathrm{yr}$ of dextral slip along its length, whereas the Vernon Fault to the north accommodates at most $4.9 \mathrm{~mm} / \mathrm{yr}$. The slip rate data for these faults, especially patterns of changing reverse and normal dip slip along strike, lead us to infer anticlockwise block rotation of narrow basement blocks bounded by the Vernon, Awatere, and Cloudy faults. The shortfall in slip-rate on the strands relative to the eastern Awatere Fault further west leads us to infer off-fault shortening on unrecognised structures in the Vernon Hills. I propose that the several blocks bounded by this system of splays are rotating anticlockwise relative to the Wairau plains because of the strong curvature on their bounding fault splays inherited from their early propagation history before the faults constituted a linked through going system. 
Moreover, a longer-term longer-wavelength vertical-axis rotation of the blocks relative to the Pacific plate has deflected the NE tips of the faults clockwise since the Neogene. This deflection has affected the oldest (inactive) southern-most Fuchia Fault the most and the youngest northern-most Cloudy Fault the least. 


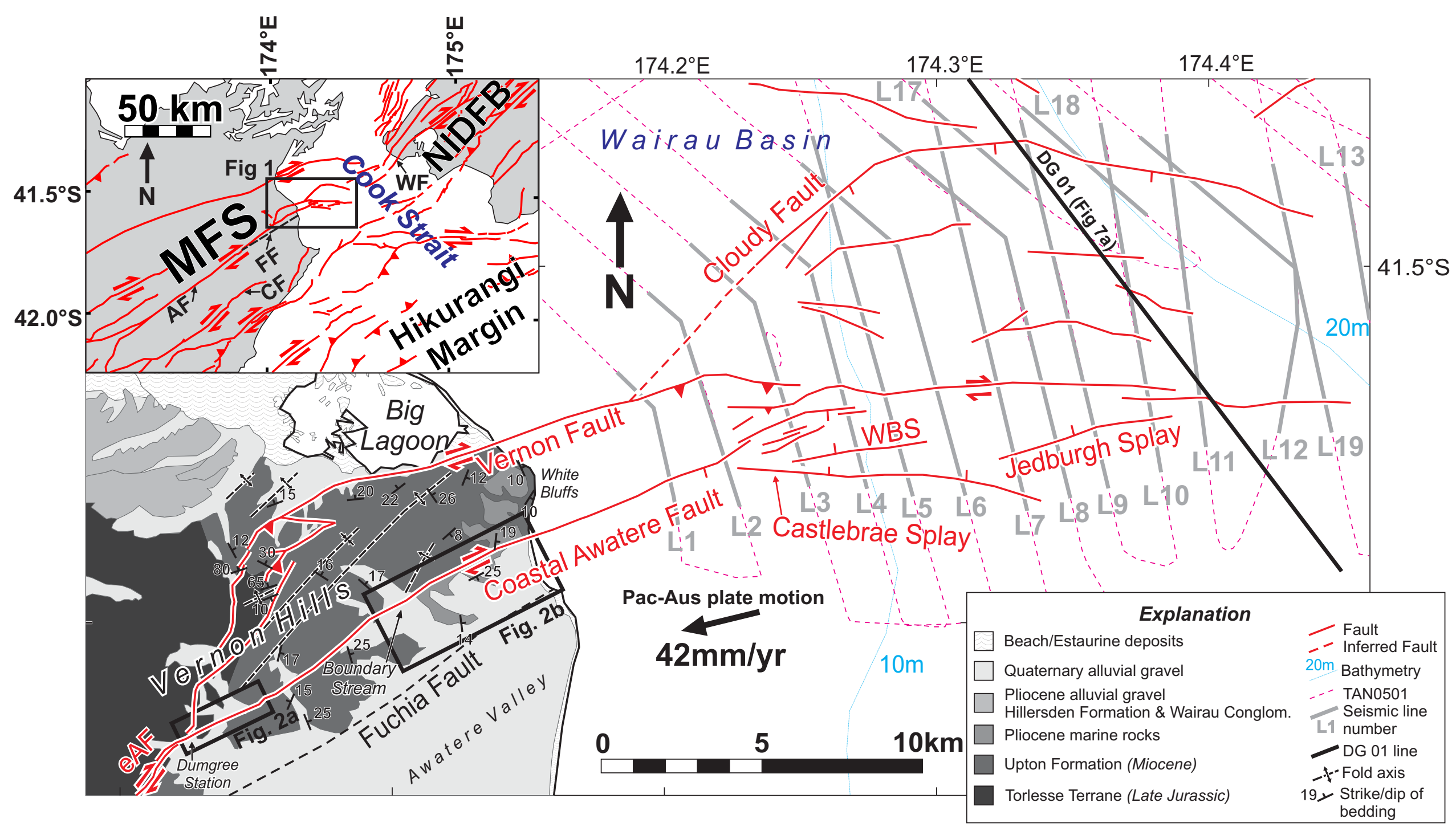

Figure 1) Geologic map of the Vernon-Awatere Fault system showing active faults, structure, bathymetry, and onshore geologic units. Offshore faults are largely from Pondard and Barnes, [2010]. The pink lines are voyage tracks from the RV Tangoroa voyage TAN0510 [Barnes and Pondard 2010; Pondard and Barnes, 2010]. The Pacific-Australian relative plate motion vector is from Beavan et al., [2002]. eAF=eastern Awatere fault, WBS= White Bluffs splay. Inset) Map showing the Marlborough Fault System (MFS), North Island Dextral Fault Belt (NIDFB) and the Hikurangi Margin. The black box shows the area of Fig 1a. Active faults are shown in red, whereas the inactive Fuschia fault (FF) is shown as a black dashed line. AF=Awatere fault, $C F=$ Clarence fault,$W F=$ Wellington fault. 


\subsection{Introduction}

Strike-slip fault zones can be complex, especially where such faults bifurcate into multiple, mutually intersecting strands. Slip where bifurcation has occurred must be partitioned between multiple splays, and may be accompanied by vertical-axis rotation of the blocks bounded by the faults and/or by internal deformation of one or more of the blocks, for example by formation of a strike-slip duplex [Cunningham and Mann, 2007]. Late Quaternary deformation within an active fault system captures a snapshot view of the temporal evolution of that fault system. In response to changing plate motions, for example, strike-slip fault systems may evolve during their life time through a sequence of initiation, propagation, slip accrual, fault block rotation, and finally abandonment [e.g. Little and Roberts, 1997; Wakabayashi, 1999]. Systems of short, obliquely oriented and disconnected splays are commonly thought to characterise the early history of strike-slip zones whereas longer, straighter, and more kinematically efficient geometries are thought to characterise their later history.

The crust of NE Marlborough is cut by a $100 \mathrm{~km}$ wide zone of dextral-oblique faults, called the Marlborough Fault System (MFS). This crust occurs in the upper plate of the Hikurangi Margin on which the Pacific plate is being subducted westward underneath the Australian plate (Fig. 1b). The active coastal Awatere, Vernon and Cloudy faults and the inactive Fuchia Fault occur in a northeast part of the MFS, and have unusually curved surface traces that mutually intersect one another, about $12 \mathrm{~km} \mathrm{SW}$ of the NE coast of the South Island. There, the Vernon Fault bifurcates northward from the Awatere Fault and the Cloudy Fault bifurcates north-eastward from the Vernon Fault $5 \mathrm{~km}$ offshore to complete the network of splays. The eastern Awatere Fault accommodates a late 
Quaternary slip rate of $6 \pm 1 \mathrm{~mm} / \mathrm{yr}$ west of the bifurcation of the Vernon Fault [Little et al., 1998; Benson et al., 2001].

East of the bifurcation, this slip must be partitioned eastwards onto the Vernon and coastal Awatere faults. The Vernon Fault has a dextral-slip rate of $1.6-4.9 \mathrm{~mm} / \mathrm{yr}$ [Chapter 1, this thesis] while previous work suggests that the coastal Awatere Fault has a slip rate of $>1.5 \mathrm{~mm} / \mathrm{yr}$ at Boundary Stream [Little et al., 1998], (Fig. 1). To the east, the two faults re-join offshore; however, there the Cloudy Fault is present as a third splay. The slip input from the eastern Awatere Fault must be shared amongst its three splays to the east of the bifurcation point of the Vernon Fault and with any off-fault deformation of the intervening blocks. Our goal is to understand how this slip has been partitioned between this complex system of splays and how the faults have evolved in time.

To reach this goal, I document the directions, amounts, and rates of late Quaternary slip on the three fault splays. The late Quaternary motions will be used to reconstruct the position of the several fault blocks backwards in time and to assess how slip has been partitioned through the fault system. Our model will also provide insight into the role of vertical-axis block rotations in the evolution of an immature strike-slip fault system consisting of diversely and poorly oriented splays. This model will attempt to explain the patterns of fault growth, splaying, and abandonment that have taken place in this NE part of the MFS since the Awatere Fault was established in the late Miocene.

I use Optically Stimulated Luminescence (OSL) and tephrochronology of the Kawakawa Tephra in late Quaternary fluvial terrace deposits and their coverbeds to constrain the age of landforms that are displaced by the coastal strand of the Awatere Fault onshore. These landform offsets will be 
measured along with neotectonic mapping of fault traces. Offshore, high frequency boomer seismic lines will be used to measure vertical slip, sense of throw, and fault dip on the eastern splays of the coastal Awatere Fault and the Cloudy Fault in Cook Strait. The age of fault-displaced reflectors imaged by the boomer seismic lines will be constrained by modelling the age of the last post glacial surface (PGS2/1) at each location. In addition to clarifying the fault evolution history, the offshore and onshore datasets from the coastal Awatere Fault will be combined with datasets from the Vernon Fault and the Cloudy Fault from Pondard and Barnes [2010] and Chapter 1 [this thesis] to provide a major upgrade in our knowledge and understanding of a major seismogenic fault system in central New Zealand. 


\subsection{Tectonic Setting}

The Marlborough Fault System (MFS) links the Hikurangi subduction margin to the NE to the zone of dextral oblique continental collision of the Alpine Fault to the SW. The Hikurangi subduction margin terminates beneath the southern end of the MFS [Reyners et al., 1998]. Cook Strait marks a conspicuous discontinuity in fault trends between the NNE striking North Island Dextral Fault Belt (NIFB) in the North Island and the NE striking MFS in the South Island [Pondard and Barnes, 2010] (Fig. 1b). The MFS today accommodates $\sim 80 \%$ of the Pacific-Australian relative plate motion by means of dextral-slip on the active Wairau, Awatere, Clarence and Hope Faults [Van Dissen and Yeats, 1991; Wallace and Beavan, 2004; Wallace et al., 2012]. These faults are estimated to have late Quaternary strike slip-rates of 4, 6, 4 and 19 mm/yr respectively [Van Dissen and Yeats, 1991; Little et al., 1998; Benson et al., 2001; Nicol and Van Dissen, 2002; Langridge et al., 2003; Mason et al., 2006]. About $12 \mathrm{~km}$ inland from the NE coast of the South Island, the eastern Awatere Fault bifurcates eastward into the coastal Awatere and the Vernon faults. Still further eastward, in the offshore, the Vernon Fault intersects with the Cloudy Fault in Cook Strait. About 4 km further east, the offshore part of the coastal Awatere Fault re-joins the Vernon Fault. This fault system thus defines a complicated map pattern of disparate splays, some of which strike almost northwards at $\sim 60^{\circ}$ to the average strike of faults in the NE part of the MFS.

Clockwise vertical-axis rotations of up to $130^{\circ}$ of rocks and faults relative to the Pacific plate have taken place in northeast Marlborough during the last $20 \mathrm{Ma}$ [Lamb, 1988; Roberts, 1995; Little and Roberts, 1997; Randall and Lamb et al., 2011; Lamb, 2011]. Paleomagnetic data indicate that rocks to the northeast of the eastward termination of the Clarence Fault (Fig. 1b) in NE Marlborough have rotated clockwise $\sim 7^{\circ} / \mathrm{Ma}$ in the last $20 \mathrm{Ma}$. There the MFS overlies subducted slab from the 
Hikurangi subduction zone. Further west in the MFS, workers have inferred either no regional rotation of the crust with respect to the Pacific plate [Little and Roberts, 1997] or less rapid rotation at a rate of $\sim 4^{\circ} / \mathrm{Ma}$ [Randall and Lamb et al., 2011]. Little and Roberts, [1997] inferred that the rotation of NE Marlborough relative to inland Marlborough has caused the eastern tips of the faults of the MFS to bend clockwise in the Cook Strait from NE strikes to ENE strikes NE and ultimately to become abandoned (Fig. 1b). 


\subsection{Analytical Methods}

\subsubsection{Onshore Neotectonic Data on the Awatere Fault}

Mapping of active fault traces and displaced landforms was undertaken using aerial photograph interpretation and direct observations on the coastal Awatere Fault within $12 \mathrm{~km}$ of the NE coast of the South Island. I measured a total of forty-five fault displacements of geomorphic landforms such as ridges, valleys, channels, and alluvial terrace surfaces on the eastern-most Awatere Fault (Table 1, Fig. 2a,b). Nine of these displacements were measured using Real-Time Kinematic Global Positioning System (RTK GPS) derived topographic maps (Table 1; Figs. 4, 5, 6), twenty-six were measured with a tape measure in areas of bush cover or where the displacements were small $<10 \mathrm{~m}$ (Table 2; Fig. 2), and ten were estimated by scaling from aerial photographs (Table 1; Fig. 2). Three other displacements are based on the previous work of Benson [2000] (Table 1; Fig. 2a,b) and Little et al. [1998], (Table 1; Figs. 2 a,b).

Using contour maps derived from RTK GPS survey data, four displacements of terrace edges, two of terrace risers, one of a ridge, one of a terrace surface and one of a hill were estimated for the Awatere Fault (Figs. 4, 5, Appendix B). Digital Elevation Models (DEMs) and contour maps were constructed by using a krigging interpolation [Oliver and Webster, 1990] of points that were surveyed at $0.25-4 \mathrm{~m}$ intervals with the Trimble R-8 RTK GPS unit. To measure strike-slip displacement of landforms, the trend of once continuous terrace edges, valleys and ridges were projected linearly to the fault plane from opposite sides of the fault. Vertical displacements (throws) were estimated by measuring the height of scarps developed on fluvial terrace surfaces using 
topographic profiles perpendicular to the fault. Strike-slip displacements of landforms in the field were measured by projecting the feature linearly to the fault from opposite sides by eye. Dip slip displacements of geomorphic features in the field were measured using levelling techniques to measure the height difference of surface projections from opposite sides of the fault. Aerial photographs were ortho-rectified, stitching $10-15$ points on the aerial photo to corresponding points on a map with rectified co-ordinates (NZTopo50-BR29) and strike-slip displacements of landforms were measured by projection of these features to the fault as above. In all of the above methods I projected markers (or surfaces) linearly to the fault across a range of possible trends to embrace the full uncertainty in these projections, a process that allowed us to estimate an uncertainty in the displacement measurement to what is approximately 95\% certainty [Little et al., 1998; 2010].

Fault-displaced river terraces were dated to provide an age constraint on the displacements. The river terraces were dated by either tephrochronology or Optically Stimulated Luminescence (OSL) dating. Dated materials included some terrace deposits beneath the treads, providing an overestimate of the timing of terrace abandonment; and some terrace coverbeds that had accumulated on the top of the abandoned tread providing an underestimate of the timing of terrace abandonment. Tephrochronological constraints were provided by identifying glass shards related to the Kawakawa Tephra (25.3 \pm 0.1 ka, [Vandergoes, 2011]), (Fig. 3). The Kawakawa Tephra is the only tephra deposit younger than 190 ka that is known to be present in the Marlborough region [Eden, 1989; Pillans, 1991; Eden and Hammond, 2003] so glass shards found in younger fluvial terrace deposits are most likely derived from it. To identify such shards, I sampled silty coverbeds of the terraces at 5-10 cm intervals and the presence or absence of glass shards was determined under microscope. OSL dating measures how long ago silt grains (in this case feldspar) were exposed to sunlight during deposition [Murray and Wintle, 2000]. Our single OSL sample (AF2, Fig. 3) was dated at the Victoria University of Wellington Luminescence Dating Laboratory. 


\subsubsection{Offshore Neotectonic data on the Vernon, Awatere and Cloudy faults}

Boomer seismic reflection data from Pondard and Barnes, [2010] were used, primarily from the voyage TAN0510 of the RV Tangoroa in the Wairau Basin. The data from TAN0510 was obtained using a 500-2000 Hz Applied Acoustic CSP-300 boomer system, providing $400 \mathrm{~km}$ of high-resolution seismic profiles running parallel to the coast spaced at 1.5-2.0 km (Fig. 1). The maximum theoretical resolution for the dataset is $\sim 40 \mathrm{~cm}$ with a penetration depth of $\sim 200 \mathrm{~m}$. Pondard and Barnes, [2010] constructed a time-stratigraphic framework in which to trace reflectors across the TAN0510 boomer profiles in the Wairau Basin (Fig. 1). In particular, the post Last-Glacial Maximum (LGM, 20 ka) sediments were identified and the erosional post last-glacial surface (PGS2/1) analysed. I traced the PGS2/1 south-eastward from the Wairau Basin (where it was previously picked by Pondard and Barnes, 2010) across strands of the Awatere Fault on 7 different boomer seismic profiles (Fig. 1). Since the PGS2/1 ravinement surface is spatially diachronous, I modelled its age at the site of each fault-profile intersection using the method outlined in Lamarche et al. [2006]; an age model that is inferred to include a $30 \%$ error.

Vertical displacement of the PGS2/1 reflector was measured by projecting the trend of the reflector to splays of the Awatere Fault from $>1 \mathrm{~km}$ away either side of the Awatere Fault splays. These projected displacements capture any distributed deformation or drag in the form of folding, making the displacements more comparable along strike as localised fault plane vertical displacements can vary. Based on the stratigraphic framework described above and the observed vertical offset of the PGS2/1 on boomer seismic lines 3-10, I measured vertical displacement rates on each offshore splay of the Awatere Fault system since the Holocene. These data were analysed and integrated with 
similar slip rate data from the Vernon Fault [Chapter 1, this thesis] and from the Cloudy Fault further to the north [Pondard and Barnes, 2010].

Maximum and minimum possible fault dips were estimated by tracing reflector cut-off by the fault with depth. Fault dip was estimated from the boomer seismic profiles by undertaking a depth conversion. I assume that the post glacial sediments have uniform densities, and that they have a uniform $v_{p}$ of $1550 \mathrm{~m} / \mathrm{s}$. In the DG01 multichannel seismic profile (acquired by Discovery Geo Corporation Pondard and Barnes, 2010, Figs. 1, 8c) fault dips were measured to a depth of $3 \mathrm{~s}$ twoway-travel time by assuming vertically varying velocity structure across the faults. A point at the tip of the fault and a point where the deepest point where the fault is imaged were picked and depth corrected using estimated rock velocities of $2-4.5 \mathrm{~km} / \mathrm{s}$. The fault dip was then calculated by using the depth difference and the horizontal difference of the two points. 


\subsection{Background Stratigraphic Framework}

\subsubsection{Miocene-Pliocene sequences}

Late Miocene and early Pliocene marine units outcrop onshore in the Vernon Hills between the Vernon and Awatere faults. There the late Miocene Upton Formation unconformably overlies the Jurassic Torlesse Terrane basement near the Vernon Fault in the Vernon Hills [Little and Jones, 1998], (Fig. 1). In the Vernon Hills, strata of the Upton Formation mostly dip $<20^{\circ}$ to the NE, and are broadly folded (interlimb angles of $\sim 160^{\circ}$ ) about axes that trend NE [Little and Jones, 1998] (Fig. 1). The Upton Formation consists chiefly of marine conglomerates, interbedded with subordinate turbiditic sandstone and mudstone. It is estimated that about $600 \mathrm{~m}$ of the Upton Formation is exposed in the Vernon Hills [Little and Jones, 1998]. Stratigraphically above and interfingering eastward with these rocks are $<150 \mathrm{~m}$ of un-named early Pliocene marine conglomerate and mudstone [Little and Jones, 1998]. The contact between the Upton Formation and the Pliocene rocks is a slight angular unconformity that is exposed at the coast at White Bluffs in the Vernon block, between the Vernon and Awatere faults [Little and Jones, 1998] (Fig. 1). North of the Vernon Fault in the Wairau Valley the Late Pliocene (2-3 Ma) Hillersden Gravels, which are fluvial, unconformably overlie the Mio-Pliocene marine units and onlap southward against the Torlesse Terrane basement [Begg and Johnston, 2000]. The Hillersden Gravels are coal-bearing gravels sourced from the Awatere region to the southwest. They were deposited syn-tectonically with uplift of the NW block of the Awatere Fault and therefore postdate that fault's inception [Little and Jones, 1998]. 


\subsubsection{Late Quaternary Marine Sequences}

Offshore of the NE coast of Marlborough on the continental shelf, the Vernon Fault bounds the southeast edge of the Wairau Basin (Fig. 1). This basin contains Quaternary shallow marine and terrestrial alluvial deposits that unconformably overlie a sequence of Pliocene and Miocene strata. During the late Quaternary, alternating terrestrial and marine sediments were deposited on this shelf as a result of repeated glacial cycles. During glacial periods, alluvial gravels prograded onto the shelf to elevations of $\sim 120 \mathrm{~m}$ below current sea level. During warmer or interglacial periods the sea level flooded the shelf again depositing transgressive muds on top of the alluvial gravels [Pondard and Barnes, 2010]. Most recently, shallow marine shelf sediments have been deposited since the LGM. The Holocene transgression caused muds to onlap up against older, syn-glacial gravels. The erosional unconformity above which the deposition of transgressive mud occurred is called the PGS 2/1 and its age is diachronous as a function of original paleo-depth: $\sim 20 \mathrm{ka}$ at the outer shelf and $\sim 7$ ka close to shore [Pondard and Barnes, 2010].

\subsubsection{Late Quaternary River Terraces}

During the late Quaternary, rivers in northeast Marlborough deposited broad gravel floodplains atop incised straths that had been cut into the older bedrock. Repeated cycles of incision, fluvial aggradation, and further incision, presumably modulated by glacial climate cycles, produced spectacular flights of river terraces in the Awatere drainage basin [Eden, 1989; Townsend, 2001]. As the land has been continually uplifted relative to sea-level, older terraces have been progressively incised by younger and lower terraces. Periods of fluvial aggradation may have coincided with periods of sea level rise, increased rainfall, and increased sediment load during the onset of 
interglacial periods [Eden, 1989; Pillans, 1991; McCalpin, 1992; Townsend, 2001]. Aeolian loess deposits found draping the alluvial gravel packages are inferred to have accumulated during later glacial periods when devegetation and stronger winds would have increased erosion, transport and deposition of windblown silt [Eden, 1989; Pillans, 1991; Townsend, 2001]. The terrace stratigraphy of the lower Awatere Valley has been well documented, mapped and dated [Eden, 1989; Little et al., 1998; Benson, 2000; Townsend, 2001], a situation that helps with correlation of terraces in our study. 
a)

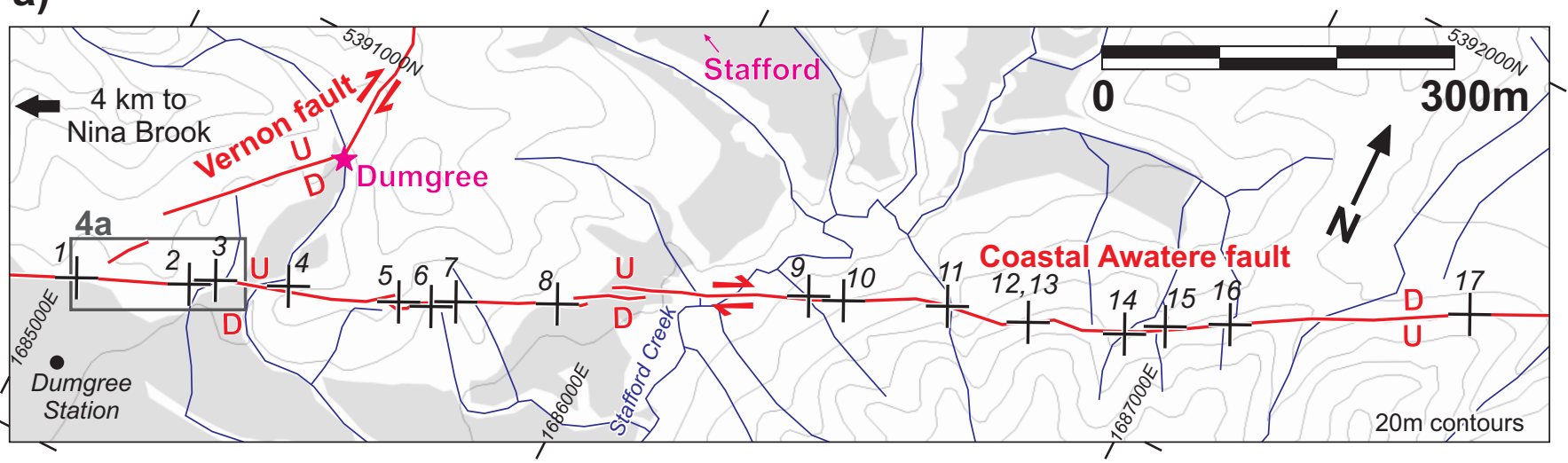

b)

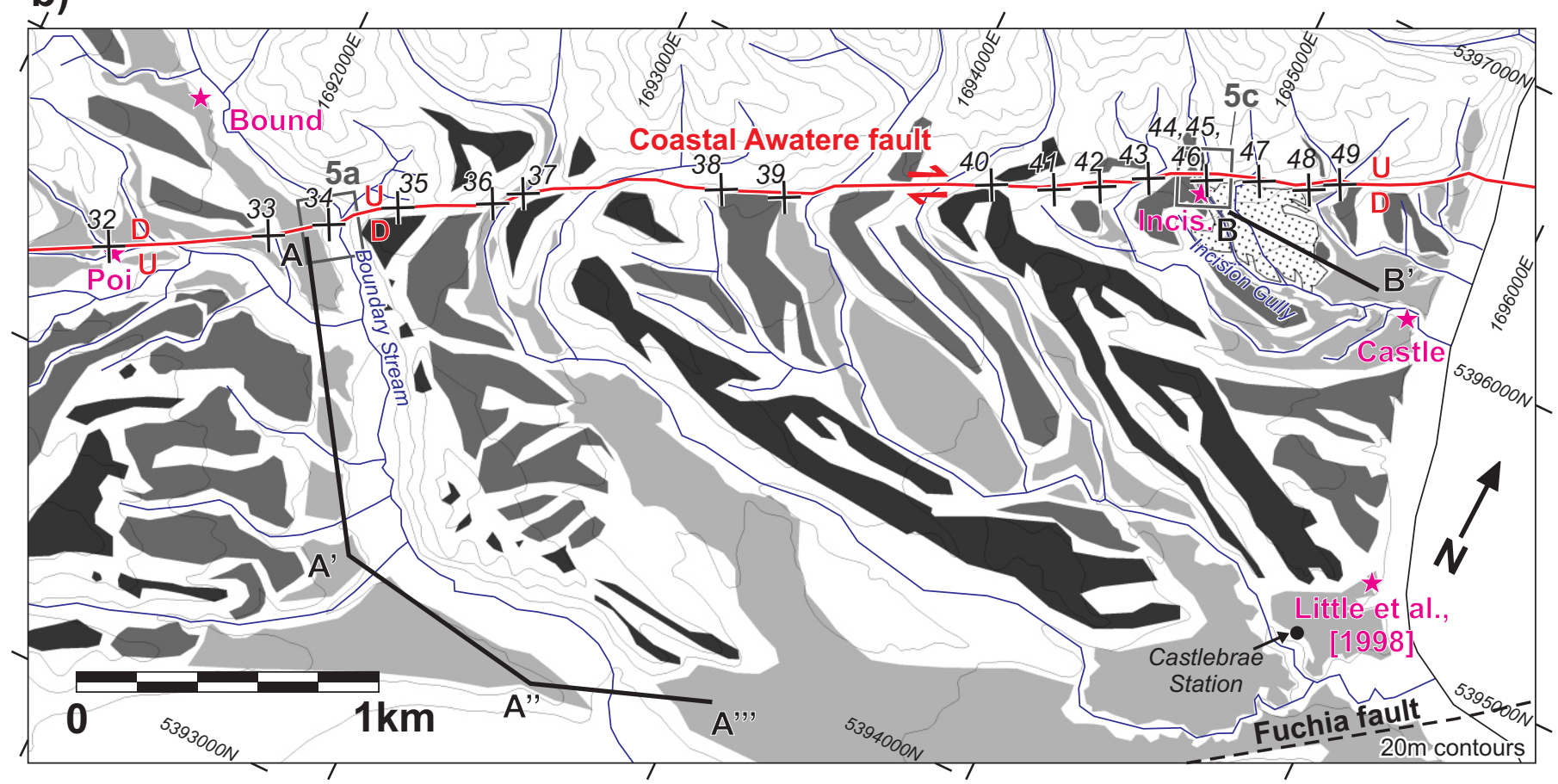

c)

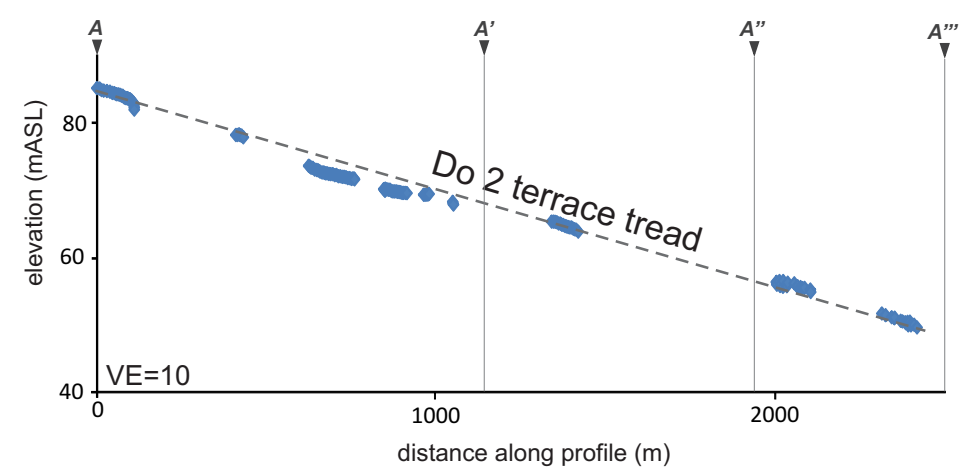

Profile B-B'

d)

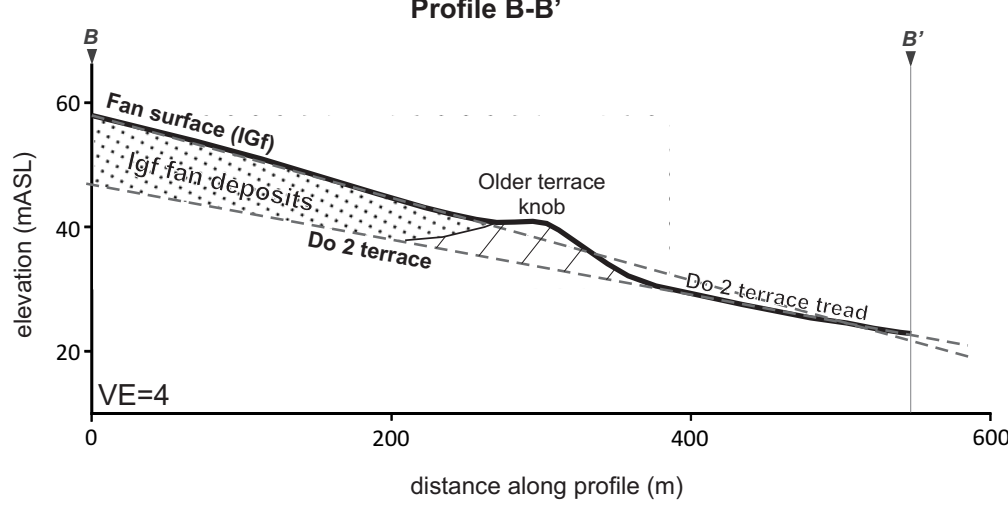

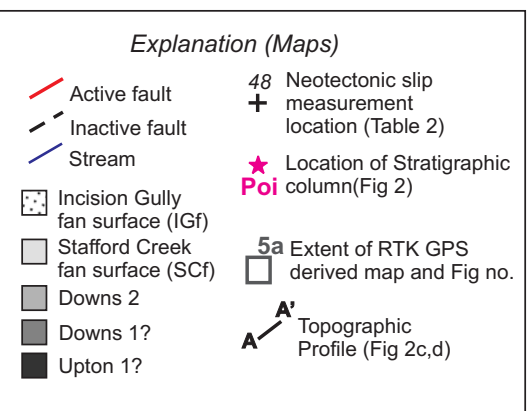

Figure $\mathbf{2} \boldsymbol{a}, \boldsymbol{b})$ Maps showing the active fault traces of the Awatere Fault, late Quaternary terraces, locations of neotectonic slip measurements, and locations of stratigraphic logs. Also shows location of RTK GPS topographic maps and profiles. Map locations are in Fig. 1. c) Profile A-A"' of the Downs 2 terrace surface at Boundary Stream. d) Profile B-B' of Incision Gully fan surface and Downs 2 terrace tread at the coast. 


\subsection{Terrace Stratigraphy Relevant to Fault Displacement Analysis}

About $11 \mathrm{~km}$ west of the coast, near Stafford Creek and Dumgree station, the coastal Awatere Fault cuts a widespread and well preserved fan surface sourced from local streams in the Vernon Hills (Fig. 3a). Benson [2000] correlated this fan to the well dated Nina Brook fan (NBf) surface based on geomorphology of the surface and called it the Stafford Creek fan surface. Our correlation is mainly based on tracing the NBf surface from Nina Brook, dissection of the surface, the geomorphology of the fan, and tephrochronology of the deposits. The NBf surface can be traced using aerial photo interpretation almost uninterrupted from Nina Brook $\sim 4 \mathrm{~km}$ NE to Stafford Creek. The NBf and SCf surfaces both have sharp degradational terrace edges against modern active streams and onlap bedrock hillslopes. Both are alluvial fans locally sourced from tributaries in the Vernon Hills. Benson, [2000] proposed that the NBf fans from the Vernon Hills, onlapped younger Starborough terrace deposits sourced from the Awatere River. I analysed the terrace deposits of the SCf in the Stafford stratigraphic section on the banks of Stafford Creek (Figs. 2a,b, 3a), where a lens of silt interbedded with the alluvial gravels $\sim 2.5 \mathrm{~m}$ below the tread contains shards of the Kawakawa Tephra. The tephra is also found at Nina Brook within a siltstone that interfingers with the NBf alluvial gravels, near the top [Little et al., 1998], hence I correlate the two fans. Little et al. [1998] and Benson [2000] dated the NBf at Nina Brook by radiocarbon dating of organic material both above ( $21 \pm 0.1 \mathrm{ka})$ and within $(20.6 \pm 0.3 \mathrm{ka})$ the fan gravels to establish that fluvial abandonment of the NBf occurred at about $21 \pm 1 \mathrm{ka}$.

One problem with the correlation of the NBf and the SCf is the difference in coverbed thickness, with the coverbeds being $50-60 \mathrm{~cm}$ thick in the Stafford and Dumgree stratigraphic sections and $1.5 \mathrm{~m}$ thick at Nina Brook [Little et al., 1998]. This could be because the SCf may be as young as the 10-12 
ka Starborough 1 terrace which also has a coverbed sequence of $\sim 50 \mathrm{~cm}$. Although I acknowledge the possibility that the SCf is younger, I correlate it to the $21 \pm 1 \mathrm{ka} \mathrm{NBf}$.

The Downs 2 (Do2) terrace was defined by Eden [1989] who noted that it is the youngest terrace in NE Marlborough to have Kawakawa Tephra in its coverbed sequence. I mapped the Do2 surface in two places: at the coast near the Awatere Fault (Castle stratigraphic section, Figs. 2b, 3f) and near Castlebrae Station at the coast [Little et al., 1998] (Fig. 2b). At the latter locality Little et al. [1998] logged the terrace deposits and identified the Kawakawa tephra at the base of the loess cover sequence and therefore indicating a correlation to the Do2 cover sequence of Eden [1989]. Further northward, at the Castle stratigraphic section (Fig. 2b, 3f) I described a $\sim 2$ m thick loess cover sequence that similarly contains the Kawakawa tephra near the base, indicating that it is the Do2 terrace. From Castlebrae station, I traced the Do2 terrace surface westwards to Boundary Stream using aerial photography and across Boundary stream by terrace projection and levelling in the field using RTK GPS (profile A-A', Fig. 3b,c). On the edge of Boundary Stream I logged the Do2 terrace deposits and coverbeds at the Boundary and Poi stratigraphic sections (Figs. 2b, 3c,d). In the Poi section (Fig. 3d) I found the Kawakawa tephra at the base of a pebbly loess overlying $\sim 2 \mathrm{~m}$ of alluvial gravels constraining the minimum age of terrace abandonment $(25.4 \pm 0.1 \mathrm{ka})$. The bottom of the Do2 loess (and thus Kawakawa tephra) was not exposed in the Boundary section but an OSL age of $35.4 \pm 1.0 \mathrm{ka}$ (Sample AF2, Fig. 2 c) was obtained from a fluvial sand lens in the terrace gravels, providing a maximum age of terrace abandonment. Hence I assign the Do2 terrace here an age of fluvial abandonment of $30 \pm 5 \mathrm{ka}$. 
a) Stafford

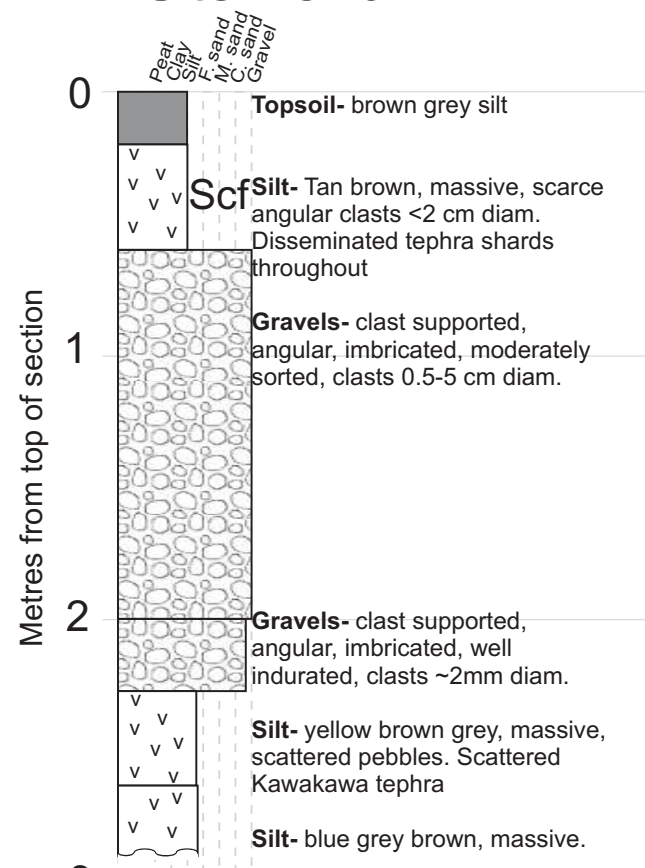

b) Dumgree
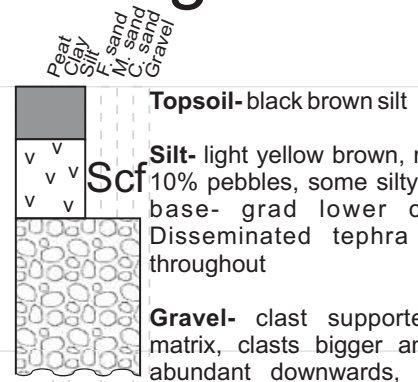

opsoil- black brown silt

Silt- light yellow brown, massive, $10 \%$ pebbles, some silty sand at base- grad lower contact. Disseminated tephra shards throughout

Gravel- clast supported, silty matrix, clasts bigger and more abundant downwards, angularsubangular, $1-10 \mathrm{~cm}$ diam. c) Boundary

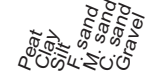

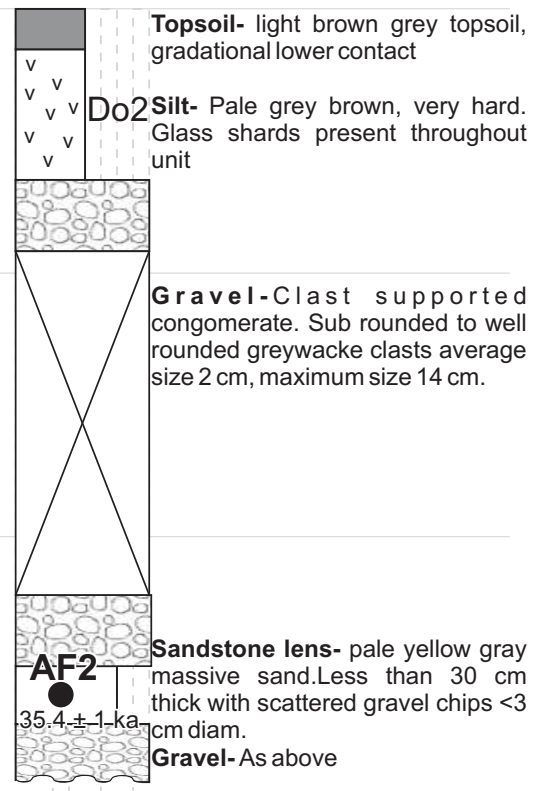

d) Poi

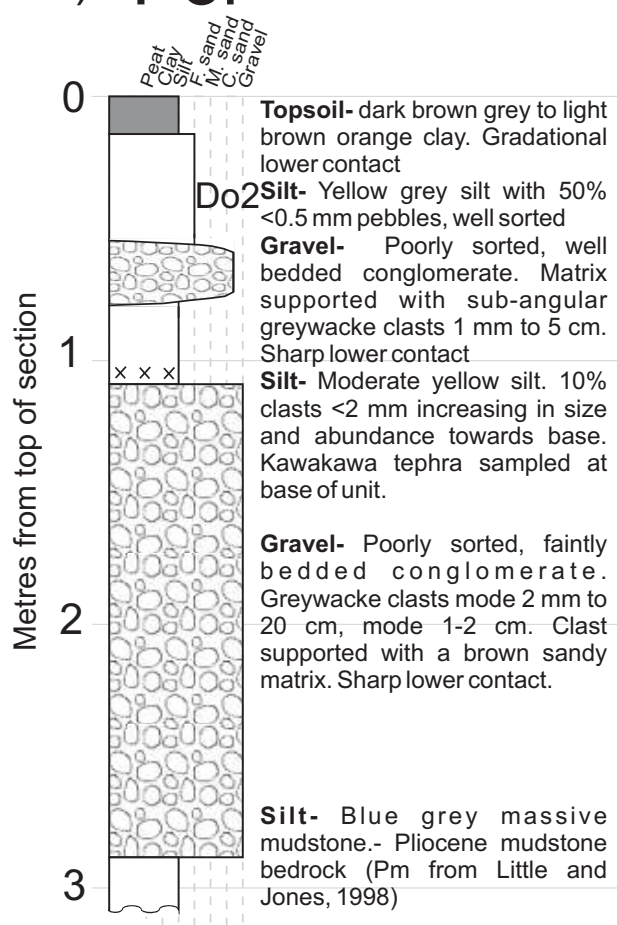

4 e) Incision

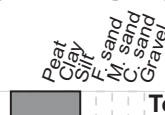
\begin{tabular}{|ll}
\hline & Topsoil- light brown grey silt, \\
& gradational lower contact.
\end{tabular}

\section{IGf}

Silt- Medium pale yellow massive sandy silt. Very hard with $<5 \mathrm{~cm}$ pebbles throughout. Grave lenses throughout $(<10 \%),<10$ $\mathrm{cm}$ thick

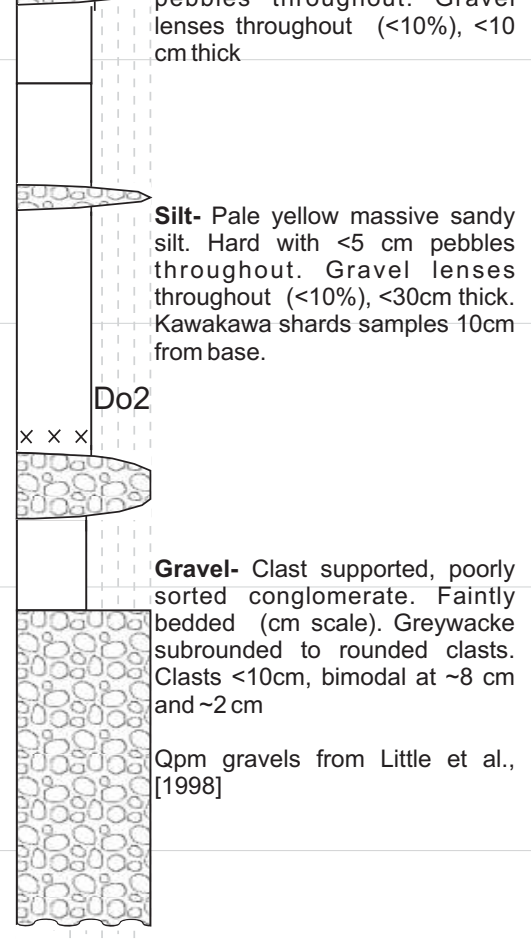

f) Castle

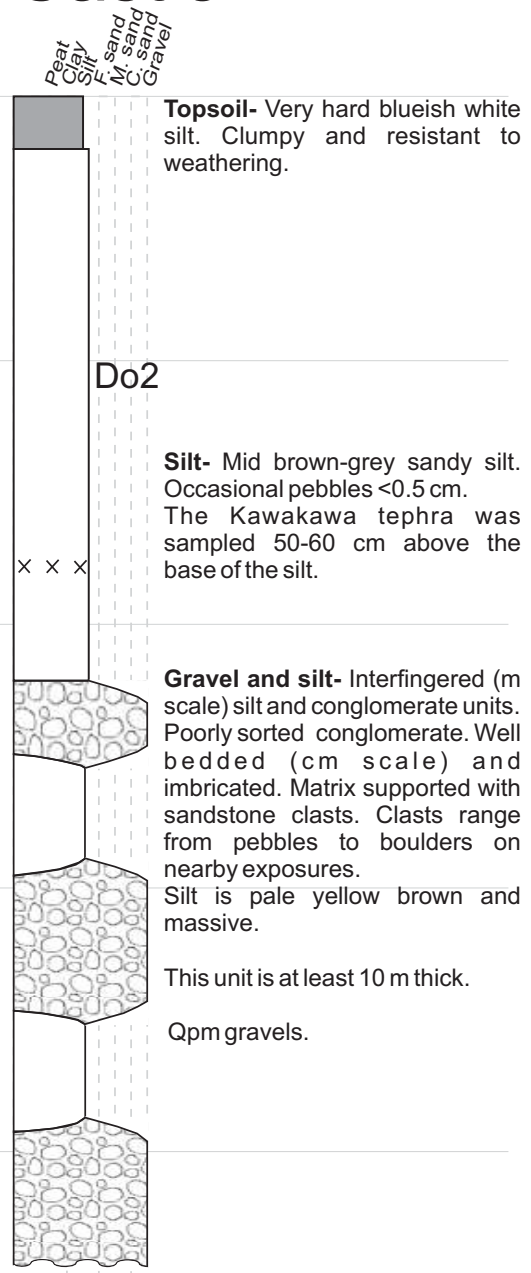

Figure 3) Stratigraphic logs of late Quaternary river terrace deposits and cover beds. Locations of the logs are in Fig 2. AF2 is an OSL sample with the age labelled. Stafford and Dumgree are of the Stafford Creek fan (SCf) gravels and loess and Incision is of deposits equivalent to the Scf. Boundary, Poi, and Castle are of the Downs 2 terrace deposits. The position of the Kawakawa Tephra is denoted by the crosses. Explanations are in the text. 
About $1 \mathrm{~km}$ SW from the coast is a small, deeply incised stream running from the Vernon Hills I call Incision Gully (Fig. 2b). On the banks of this stream is an alluvial fan I call the Incision Gully fan (IGf) surface which forms an apron of gravel shed from the Vernon Hills. This apron overlaps the coastal Awatere Fault and is cut by it (Fig. 5b). I interpret the fan to be younger than the Do2 terrace because it onlaps against the Do2 surface on the banks of Incision Gully (Fig. $2 b$,d) and because it has a steeper surface gradient than the underlying Do2 (see profile B-B' Figs. $2 b$, d). At the Incision stratigraphic section (Fig. 3e) $\sim 3 \mathrm{~m}$ of silt and gravel overlie coarser alluvial gravels that also underlie the Do2 terrace coverbed at the coast (in the Castle stratigraphic section and in Little et al., 1998; Figs. 2b, 3f). Near the base of the silt I sampled shards of the Kawakawa tephra. This indicates that the lower part of the silt is part of the Do2 cover sequence. The silt has gravel lenses throughout, becoming less abundant and thick upwards, which indicates that the IGf was aggrading after deposition of the Do2 terrace. Since the SCf is younger than the 30 ka Do2 terrace and is a locally sourced fan I infer that it aggraded in association with the LGM, similar in age to the NBf and SCf fans that have an age of $21 \pm 1$ ka [Little, 1998; Benson, 2000]. 


\begin{tabular}{|c|c|c|c|c|c|c|c|c|c|c|c|c|c|c|}
\hline Site & Northing ${ }^{1}$ & Easting $^{1}$ & $\begin{array}{c}\text { Dextral } \\
\text { disp. }(m)\end{array}$ & $\begin{array}{c}\text { Dip slip } \\
\text { disp. (m) }\end{array}$ & $\begin{array}{c}\mathrm{D} / \text { thrown } \\
\text { side }\end{array}$ & Feature & Method & $\begin{array}{l}\text { Feat. } \\
\text { dated }\end{array}$ & $\begin{array}{l}\text { Min } \\
\text { age } \\
\text { (ka) }\end{array}$ & $\begin{array}{l}\text { Max } \\
\text { age } \\
\text { (ka) }\end{array}$ & $\begin{array}{c}\text { Strike slip } \\
\text { rate } \\
(\mathrm{mm} / \mathrm{yr})\end{array}$ & $\begin{array}{c}\text { Dip slip rate } \\
\text { (mm/yr) }\end{array}$ & $\mathrm{H} / \mathrm{V}$ ratio & $\begin{array}{l}\text { Strike/dip } \\
\text { of fault }{ }^{3}\end{array}$ \\
\hline 1 & 5390300 & 1684997 & $47 \pm 10$ & $5 \pm 1$ & SE & Terrace surf. & RTK (Fig 4a) & SCf & $21 \pm 1$ & & $<2.2 \pm 0.6$ & $0.2 \pm 0.06$ & $9.4 \pm 4$ & $066 / 90^{\circ}$ \\
\hline 2 & 5390411 & 1685228 & $55 \pm 15$ & & & Hill & RTK (Fig 4a) & SCf & $21 \pm 1$ & & $<2.6 \pm 0.8$ & & & $059 / 90^{\circ}$ \\
\hline 3 & 5390437 & 1685267 & $57 \pm 7$ & $4 \pm 1$ & SE & Terrace surf. & RTK (Fig 4a) & SCf & $21 \pm 1$ & & $<2.7 \pm 0.5$ & $0.2 \pm 0.06$ & $14 \pm 5$ & $059 / 90^{\circ}$ \\
\hline 4 & 5390498 & 1685407 & $65 \pm 20$ & & SE & Active chan. & aerial photo & SCf & $21 \pm 1$ & & $<3.1 \pm 1.0$ & & & $069^{\circ}$ \\
\hline 5 & 5390568 & 1685614 & $45 \pm 10$ & & & Ridge & tape meas. & & & & & & & $060^{\circ}$ \\
\hline 6 & 5390698 & 1685674 & $5 \pm 2$ & & & Active chan. & tape meas. & & & & & & & $060^{\circ}$ \\
\hline 7 & 5390627 & 1685713 & $25 \pm 8$ & & & Active chan. & tape meas. & & & & & & & $063^{\circ}$ \\
\hline 8 & 5390652 & 1685783 & & $0.8 \pm 0.2$ & SE & Terrace surf. & RTK (App. A) & SCf & $21 \pm 1$ & & $<3.1 \pm 0.8$ & $0.04 \pm 0.01$ & $81 \pm 39$ & $054^{\circ}$ \\
\hline 9 & 5390979 & 1686370 & $18 \pm 7$ & & & Active chan. & tape meas. & & & & & & & $063^{\circ}$ \\
\hline 10 & 5390984 & 1686406 & $45 \pm 10$ & & & Aband. chan. & tape meas. & & & & & & & $063^{\circ}$ \\
\hline 11 & 5391073 & 1686574 & $16 \pm 4$ & & & Active chan. & tape meas. & & & & & & & $080^{\circ}$ \\
\hline 12 & 5391096 & 1686764 & $12 \pm 5$ & & & Active chan. & tape meas. & & & & & & & $061^{\circ}$ \\
\hline 13 & 5391096 & 1686764 & $25 \pm 5$ & & & Aband. chan. & tape meas. & & & & & & & $061^{\circ}$ \\
\hline 14 & 5391209 & 1686953 & $60 \pm 15$ & & & Active chan. & tape meas. & & & & & & & $064^{\circ}$ \\
\hline 15 & 5391236 & 1686984 & $25 \pm 5$ & & & Active chan. & tape meas. & & & & & & & $062^{\circ}$ \\
\hline 16 & 5391303 & 1687114 & $42 \pm 10$ & & & Active chan. & aerial photo & & & & & & & $065^{\circ}$ \\
\hline 17 & 5391542 & 1687510 & $4 \pm 0.5$ & $<0.5$ & NW & Active chan. & tape meas. ${ }^{2}$ & & & & & & $>9$ & $057^{\circ}$ \\
\hline 18 & 5391715 & 1687858 & $190 \pm 30$ & $10 \pm 5$ & NW & Aband. chan. & EDM survey ${ }^{2}$ & & & & & & $19 \pm 13$ & $058^{\circ}$ \\
\hline 19 & 5392262 & 1688658 & $36 \pm 8$ & & & Active chan. & tape meas. & & & & & & & $057^{\circ}$ \\
\hline 20 & 5392339 & 1688774 & $20 \pm 5$ & & & Active chan.I & tape meas. & & & & & & & $058^{\circ}$ \\
\hline 21 & 5392601 & 1689190 & $170 \pm 30$ & & & Gully & aerial photo & & & & & & & $060^{\circ}$ \\
\hline 22 & 5392701 & 1689352 & $35 \pm 5$ & & & Active chan. & tape meas. & & & & & & & $049^{\circ}$ \\
\hline 23 & 5392737 & 1689391 & $30 \pm 5$ & & & Active chan. & tape meas. & & & & & & & $049^{\circ}$ \\
\hline 24 & 5392854 & 1689520 & $30 \pm 8$ & & & Active chan. & tape meas. & & & & & & & $047^{\circ}$ \\
\hline 25 & 5392906 & 1689574 & $30 \pm 5$ & & & Active chan. & tape meas. & & & & & & & $047^{\circ}$ \\
\hline 26 & 5393532 & 1690255 & $25 \pm 5$ & & & Active chan. & tape meas. & & & & & & & $045^{\circ}$ \\
\hline 27 & 5393598 & 1690311 & $3.1 \pm 0.5$ & & & Active chan. & tape meas. & & & & & & & $045^{\circ}$ \\
\hline 28 & 5393673 & 1690399 & $5 \pm 1$ & $>1$ & SE & Active chan. & tape meas. & & & & & & $<6$ & $054^{\circ}$ \\
\hline 29 & 5393554 & 1690683 & $35 \pm 10$ & & & Active chan. & tape meas. & & & & & & & $051^{\circ}$ \\
\hline 30 & 5394086 & 1690932 & $90 \pm 20$ & & & Terrace edge & aerial photo & Do1? & $60 ?$ & & $<1.5$ & & & $059^{\circ}$ \\
\hline 31 & 5394179 & 1691087 & $7 \pm 1$ & $>1$ & SE & Active chan. & tape measure & & & & & & $<8$ & $060^{\circ}$ \\
\hline 32 & 5394408 & 1691536 & $30 \pm 5$ & $1.5 \pm 0.5$ & NW & Active chan. & RTK (App. A) & Do2 & & $30 \pm 5$ & $>1.0 \pm 0.3$ & $0.03 \pm 0.02$ & $30 \pm 20$ & $065^{\circ}$ \\
\hline 33 & 5394674 & 1692020 & $35 \pm 10$ & & & Riser & RTK (App. A) & Do2 & & $30 \pm 5$ & $>1.2 \pm 0.5$ & & & $060^{\circ}$ \\
\hline 34 & 5394785 & 1692187 & $33 \pm 7$ & $3.5 \pm 0.5$ & SE & Riser & RTK (Fig 5a) & Do2 & & $30 \pm 5$ & $>1.1 \pm 0.3$ & $0.1 \pm 0.03$ & $9.4 \pm 3$ & $047^{\circ} / 76$ \\
\hline 35 & 5394939 & 1692386 & $3.7 \pm 0.2$ & & & Active chan. & tape meas. ${ }^{3}$ & & & & & & & $062^{\circ}$ \\
\hline 36 & 5395109 & 1692667 & $14 \pm 4$ & & & Active chan. & tape meas. & & & & & & & $056^{\circ}$ \\
\hline 37 & 5395175 & 1692745 & $120 \pm 20$ & & & Gully & aerial photo & & & & & & & $056^{\circ}$ \\
\hline 38 & 5395475 & 1693423 & $375 \pm 50$ & & & Aband. gully & aerial photo & & & & & & & $068^{\circ}$ \\
\hline 39 & 5395568 & 1693548 & $6 \pm 2$ & & & Active chan. & tape meas. & & & & & & & $069^{\circ}$ \\
\hline 40 & 5395907 & 1694205 & $460 \pm 100$ & & & Gully & aerial photo & & & & & & & $067^{\circ}$ \\
\hline 41 & 5395964 & 1694389 & $4 \pm 0.5$ & & & Active chan. & tape meas. & & & & & & & $063^{\circ}$ \\
\hline 42 & 5396064 & 1694534 & $450 \pm 100$ & & & Aband. gully & aerial photo & & & & & & & $062^{\circ}$ \\
\hline 43 & 5396126 & 1694673 & $200 \pm 50$ & & & Gully & aerial photo & & & & & & & $061^{\circ}$ \\
\hline 44 & 5396223 & 1694842 & $15 \pm 3$ & $1 \pm 0.5$ & & Terrace edge & RTK (Fig 5b) & $\mathrm{SCf}$ & $21 \pm 1$ & & $<0.7 \pm 0.2$ & $0.05 \pm 0.04$ & $15 \pm 11$ & $066 / 90^{\circ}$ \\
\hline 45 & 5396235 & 1694860 & $23 \pm 12$ & & & Gully & RTK (Fig 5b) & scf & $21 \pm 1$ & & $<1.1 \pm 0.6$ & & & $066 / 90^{\circ}$ \\
\hline 46 & 5396245 & 1694890 & $13 \pm 4$ & & & Ridge & RTK (Fig 5b) & SCf & $21 \pm 1$ & & $<0.6 \pm 0.3$ & & & $066 / 90^{\circ}$ \\
\hline 47 & 5396300 & 1695019 & $26 \pm 5$ & $>1.5$ & SE & Active chan. & tape meas. & SCf & & $21 \pm 1$ & $>1.2 \pm 0.3$ & $>0.07$ & $<14$ & $070^{\circ}$ \\
\hline 48 & 5396357 & 1695188 & $3.5 \pm 1$ & & & Active chan. & tape meas. & & & & & & & $070^{\circ}$ \\
\hline 49 & 5396388 & 1695253 & $90 \pm 20$ & & & Gully & aerial photo & & & & & & & $067^{\circ}$ \\
\hline
\end{tabular}

Table 1) Table of fault slip measurements from the locations displayed in Figs $3 a, b$, and c. ${ }^{1}$ Eastings and Northings are from the New Zealand Transverse Mercator 2000 (NZTM 2000) projection system on the map NZTopo50-BR29. ${ }^{2}$ Benson $[2000]^{3}$ Little et al. $[1998]^{4}$ Shown in stratigraphic sections in Fig. 2. 


\subsection{Neotectonics of the Awatere, Vernon, and Cloudy Faults}

\subsubsection{Neotectonics of the coastal Awatere Fault}

The coastal Awatere Fault is defined to be the section of the Awatere Fault that continues eastward to the coast from the Awatere Fault's junction with the Vernon Fault. At this junction the Vernon fault bifurcates northward away from the eastern Awatere Fault near Dumgree Station (Figs. 1, 2a). Onshore, the coastal Awatere Fault has a similar $\sim 066^{\circ}$ average strike to the eastern Awatere Fault. In bedrock it separates late Miocene Upton marine gravels to the northwest (in the Vernon Hills) from late Miocene Upton marine gravels or late Quaternary river terraces to the southeast (in the lower Awatere Valley, Fig. 1). Less than $5 \mathrm{~km}$ offshore of NE Marlborough, a similar bedrock juxtaposition of bedrock units is imaged in boomer seismic lines 1 and 2 (Fig. 1, 6a). There, MiocenePliocene rocks exposed at a seafloor reef to the northwest of the coastal Awatere Fault are onlapped by Late Quaternary marine/alluvial deposits (not post glacial) to the southeast of the fault (Figs. 6a). On the boomer seismic lines east of line 2 (Fig. 1), the late Miocene and Pliocene marine deposits are overlain by late Quaternary marine/alluvial (including post-glacial) sediments on both sides of the coastal Awatere Fault zone; which include the main strand of the coastal Awatere Fault (cAF) plus the previously un-named White Bluffs (WBS), Castlebrae (CS), and Jedburgh splays (JS), which bifurcate eastward from it (Fig. 1).

The coastal Awatere Fault is a dextral slip fault with a horizontal to vertical slip ratio $(\mathrm{H}: \mathrm{V})$ of $>6$ (Table 1) onshore and offshore (Fig. 1), and with a varying dip-slip component along strike. The fault is mainly upthrown to the NW onshore but this varies locally. The fault dips steeply $\left(>70^{\circ}\right)$ to either 
the NW or the SE in in exposures onshore and offshore (Table 1). By observing the deflection (or lack of) of the fault trace across topography, I estimate that the coastal Awatere Fault has a steep dip to the NW or the SE onshore, with a near vertical dip near Dumgree station and Incision Gully (Fig. 4 a,b) and a dip of $\sim 70^{\circ}$ to the SE at Boundary Stream (Fig. 1, 5a). Offshore, on the westernmost boomer seismic lines 1-4 indicate that the coastal Awatere Fault dips to the SE at $>50-85^{\circ}$ and that it is downthrown to the SE (Table 2, Fig. 6). The White Bluffs, Castlebrae, and Jedburgh splays splay eastward near the offshore termination of the coastal Awatere fault. Seismic data indicate that these splays also have normal to vertical fault geometries (Table 2, Fig. 6). Hence the coastal Awatere Fault is approximately vertical onshore but transitions eastward to become gradually more normal offshore, where it bifurcates into several splays at the eastern tip of the Awatere Fault zone.

A marked eastward reduction in Quaternary dextral-slip rate has previously been inferred on the coastal Awatere Fault relative to the central section of the Awatere Fault to the west of the Vernon Fault's bifurcation point [Little et al., 1998; Benson et al., 2001]. Less than $4 \mathrm{~km}$ southwest of Dumgree Station, the eastern Awatere Fault has a late Quaternary slip rate of $6 \pm 1 \mathrm{~mm} / \mathrm{yr}$ since 65 ka [Benson et al., 2001]. East of the fault junction with the Vernon Fault, the coastal Awatere Fault at Boundary Stream (Fig. 1), by contrast, was estimated to have a maximum slip rate of $1.4 \pm 0.5$ $\mathrm{mm} / \mathrm{yr}$. The measurement was based on an offset canyon wall that was inferred to be filled by gravels of the Do2 alluvial terrace sequence [Little, et al., 1998]. Such an eastward slip reduction on the Awatere Fault implies that slip has been partitioned eastwards into into the Vernon Fault and/or into some kind of off-fault deformation [Little et al., 1998; Benson, 2001]. 
a)

Today
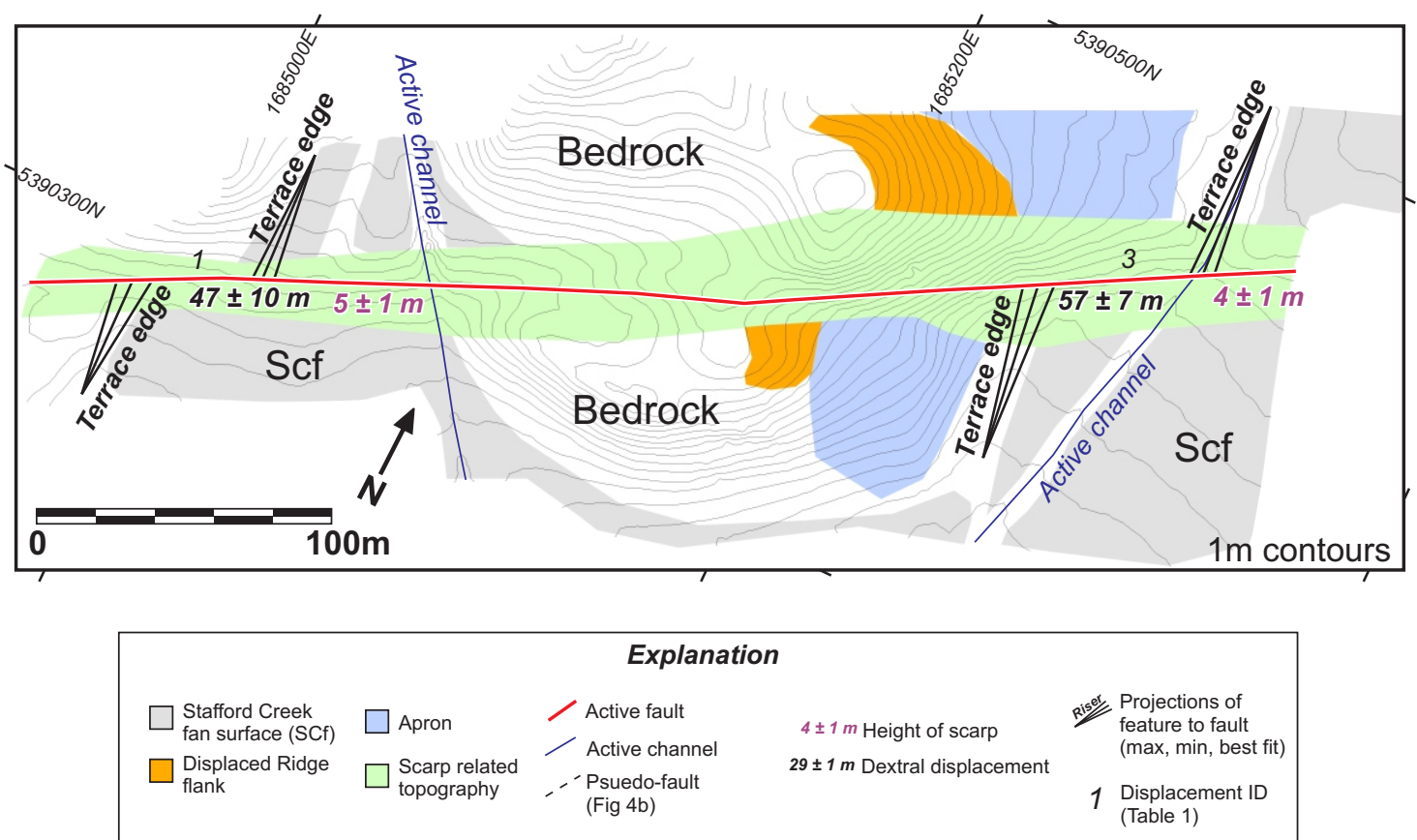

b) Best fit strike- slip palinspastic reconstruction of Dumgree Hill 56 m (2)

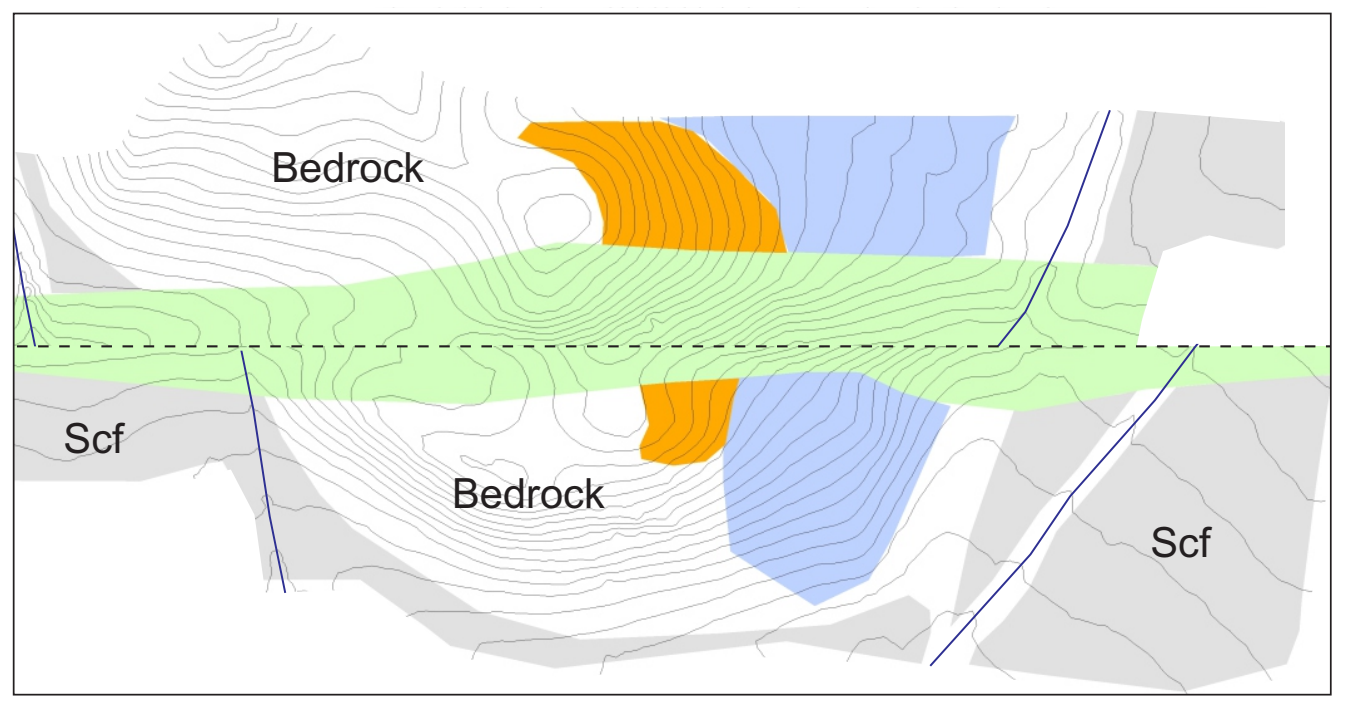

Figure 4 a) RTK GPS derived topographic map of Dumgree Hill and other nearby displaced landforms. b) Palinspastic reconstruction to reconstruct Dumgree Hill when the Scf onlapped the hill, before subsequent reconstruction. The hill is displaced $56 \pm 15 \mathrm{~m}$. 
Near Dumgree Station, the Vernon Fault splays northward from the central part of the Awatere Fault. Less than $1 \mathrm{~km}$ east of this bifurcation, the coastal section of the Awatere Fault cuts through the SCf surface and related bedrock slopes and ridges that the SCf fan onlaps against. The SCf fan system was shed southeast from the Vernon Hills across the trace of the coastal Awatere Fault which has displaced it dextrally (Fig. 2a, 4). A small bedrock hill I call Dumgree Hill is onlapped by the SCf and has been dextrally displaced by the coastal Awatere Fault. Using RTK GPS, I surveyed this hill to produce a detailed topographic map of the fault offset (Fig. 4a). I retro-deformed the displaced topography of this hill sinistrally, lining up the displaced ridge flank and apron on the eastern side of the hill (highlighted in Fig. 4a) as well as the knob and the western flank of the complexly shaped hill (Fig. 4b). Our best fit reconstruction indicates that the hill has been displaced $55 \pm 20 \mathrm{~m}$ dextrally by the coastal Awatere Fault (Offset 2, Table 1, Fig. 2a). The age of this displacement must predate the SCf gravels that onlap the hill, yielding a maximum slip rate estimate of $2.6 \pm 1.0 \mathrm{~mm} / \mathrm{yr}$. Scarps (up on the NW) in the SCf each side of Dumgree Hill are $5 \pm 1 \mathrm{~m}$ high and $4 \pm 1 \mathrm{~m}$ high (site 1 and 3 , Table 1, Fig. 4a), based on surveyed profiles across the fault scarp. These data indicate a maximum vertical displacement rate of $\sim 0.2 \mathrm{~mm} / \mathrm{yr}$ at this locality.

Figure 5) RTK GPS derived topographic map of landforms that are displaced by the coastal Awatere Fault showing active fault traces, late Quaternary landforms, fault dip and displacement measurements. a) Displacement of a riser in the Do2 on the eastern bank of Boundary Stream. Also shown schematically is our measurement of the displacement presented in Little et al. [1998] of the back of the Do2 terrace tread which onlaps the canyon wall. b) Displacements of landforms at a location I call Incision Gully (Fig. 2b). Displacements include the back of the IGf terrace tread which onlaps the eastern ridge flank, the gully, and the western ridge. Profiles $i-v$ show the ridge flankterrace tread intersection points. 
5a)

b)
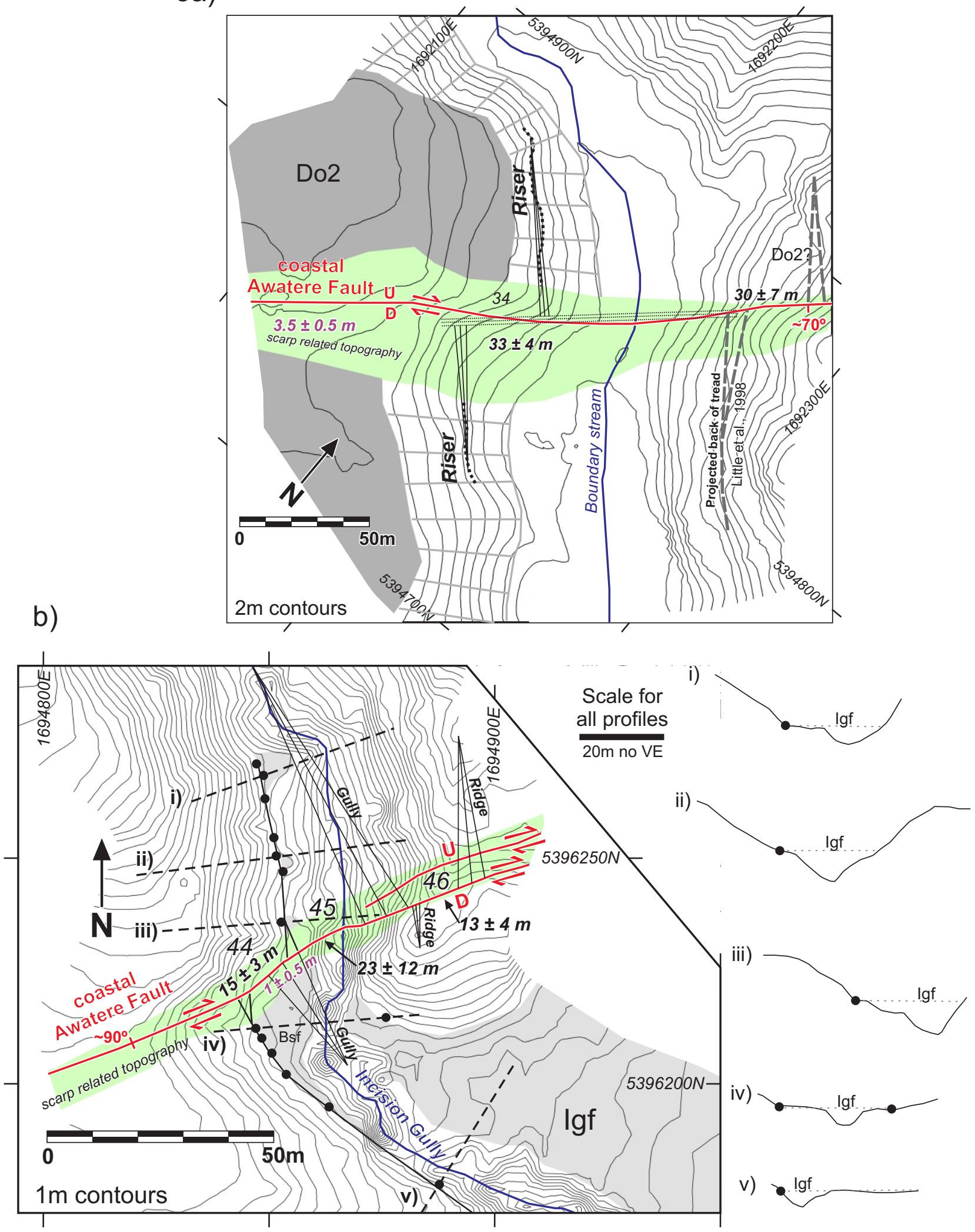

Explanation

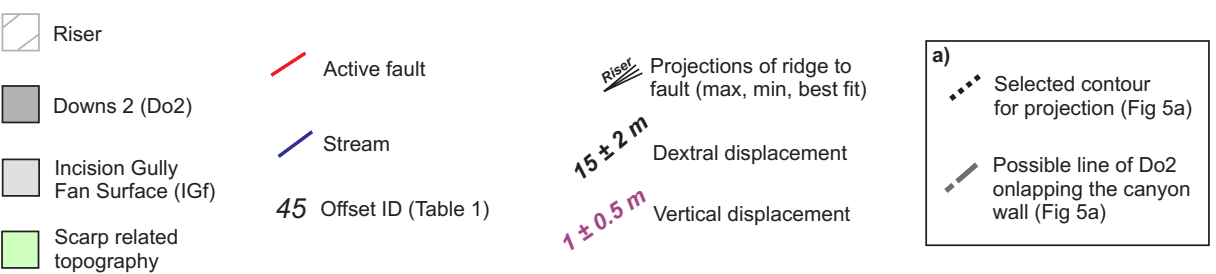

b) 
At Boundary Stream, $4 \mathrm{~km}$ inland from the coast, I revisited a site originally investigated by Little et al. [1998]. There, they estimated the dextral displacement of the onlapped boundary between the Do2 aggradational terrace gravels and the older bedrock canyon wall. Because the Do2 terrace remnant on the northern side of the fault and eastern wall of the canyon is slumped, the onlapped terrace edge is hard to define (Fig. 5a). For this study, I instead measured the terrace edge (riser) between the higher Do2 terrace and the lower terrace of unknown age on the west of Boundary Stream. The dextral displacement of this riser was originally estimated as $35 \mathrm{~m}$ by Little et al. [1998]. Re-measured, using RTK GPS topographic mapping, I obtain a dextral displacement of $33 \pm 7 \mathrm{~m}$ (Offset 34, Figs. 2b, 5a, Table 1). To achieve this dextral-slip estimate, I first measured the throw on the Do2 terrace surface. This was found to be $3.5 \pm 0.5 \mathrm{~m}$ on the basis of topographic profiles surveyed perpendicular to the fault. Second, a contour near the middle of the riser on the uplifted north side of the fault and an inferred once-correlative contour $3.5 \mathrm{~m}$ lower than that on the south side of the fault were picked and projected linearly to the fault from both sides (Fig. 5a). Based on the variable curvature and trend of these markers, a triangular-shaped maximum range of projection lines were projected to the fault from each side, encasing a range of uncertainty in the displacement estimate [Little et al., 2010]. From these data and assuming a maximum age of $30 \pm 5 \mathrm{ka}$ for the riser, I infer a minimum dextral slip rate of $1.1 \pm 0.3 \mathrm{~mm} / \mathrm{yr}$ and a minimum dip slip rate of $0.11 \pm 0.03$ $\mathrm{mm} / \mathrm{yr}$ at this location. These slip rates are considered minima because incision of the Do2 surface to form the riser occurred sometime after terrace abandonment of the upper Do2 terrace of the riser.

At Incision Gully $\sim 1 \mathrm{~km}$ inland from the coast along the coastal Awatere Fault (Fig. 2b), I measured dextral displacements by the fault of a terrace edge, a gully, and a ridge using an RTK GPS derived topographic map (Fig. 5b). These displacements are age constrained by the inferred $21 \pm 1$ ka age of the Incision Gully fan surface (IGf) as described above (Fig. 5b). The three displacements offset the edges of the IGf surface, which partially infilled the incised the walls of a pre-existing gully. On the 
north side of the fault, the gully is cut into Pliocene mudstone [Little and Jones, 1998]. This bedrock is overlain by remnants of the IGf on the flanks of the active stream. On the south side of the fault, the IGf downlaps SE away from the coastal trace of the Awatere fault. The IGf onlaps a protruding ridge of older terrace material on the western side of the active stream (Fig. $5 b$ ). The active stream is incised into the IGf terrace deposits to depths of up to $5 \mathrm{~m}$. The intersection line between the surface of the IGf and the western wall of the bedrock canyon is displaced $15 \pm 3 \mathrm{~m}$ dextrally (44, Fig. $2 \mathrm{~b}$, Table 1). This estimate was obtained by mapping the intersection lines of the terrace tread against the canyon wall using profiles across the survey data (Figs. 5b i-v), and projecting the intersection linearly to the fault from each side (Fig. 5b). The middle of the bedrock gully is displaced $23 \pm 12 \mathrm{~m}$ dextrally, whereas a bedrock ridge on the eastern side of Incision Gully is displaced $13 \pm 4$ m dextrally (45 and 46, Fig. 2b,Table 1). These dextral displacements are within error of each other and indicate a maximum slip rate of $1.1 \pm 0.6 \mathrm{~mm} / \mathrm{yr}$. The slip rates are maxima because the age of IGf surface only provides a minimum age of formation of the displaced gully wall, for bedrock gully incision, and for the ridge formation. A $1 \pm 0.5 \mathrm{~m}$ high scarp was measured in the IGf on the western side of the stream by running profiles perpendicular to the fault along remnants of the fan surface. These data yielded a maximum vertical displacement rate estimate of $0.05 \pm 0.04 \mathrm{~mm} / \mathrm{yr}$. When the dextral-slip rate data from Boundary Stream and Incision Gully are combined (one a maximum and one a minimum), I bracket the dextral slip-rate since $20-30 \mathrm{ka}$ to be between $1.1 \pm 0.3 \mathrm{~mm} / \mathrm{yr}$ and $1.1 \pm 0.6 \mathrm{~mm} / \mathrm{yr}$. In short, the slip rate of the coastal Awatere fault is approximately $1.1 \mathrm{~mm} / \mathrm{yr}$ at the coast, whereas $\sim 11 \mathrm{~km}$ to the SW near Dumgree Station the slip rate is $<2.6 \mathrm{~mm} / \mathrm{yr}$. 


\begin{tabular}{|c|c|c|c|c|c|c|c|c|c|c|c|}
\hline Fault & Splay & $\begin{array}{l}\text { Line } \\
\text { no. }\end{array}$ & $\begin{array}{c}\text { Dist. from } \\
\text { coast }\end{array}$ & $\operatorname{Dip}\left({ }^{\circ}\right)$ & $\begin{array}{c}\text { Dip } \\
\text { direction }\end{array}$ & $\begin{array}{c}\text { Upthrown } \\
\text { side }\end{array}$ & $\begin{array}{l}\text { Dip-slip } \\
\text { sense }\end{array}$ & $\begin{array}{c}\text { Age of best } \\
\text { reflector } \\
\text { (ka) }\end{array}$ & $\begin{array}{c}\text { Vert. } \\
\text { Displace. } \\
(\mathrm{m})\end{array}$ & $\begin{array}{c}\text { Vert. } \\
\text { displace. rate } \\
\text { (mm/yr) }\end{array}$ & Comment \\
\hline $\mathrm{CAF}$ & $\mathrm{AF}$ & 1 & 5.4 & $50-80$ & SE & NW & Normal & & & & \\
\hline $\mathrm{CAF}$ & $\mathrm{AF}$ & 3 & 9.2 & $55-85$ & SE & NW & Normal & $15.6 \pm 1$ & $6.2 \pm 0.4$ & $0.4 \pm 0.05$ & \\
\hline $\mathrm{CAF}$ & AF NS & 4 & 11.2 & $55-85$ & SE & NW & Normal & $17.5 \pm 1.6$ & $1.1 \pm 0.7$ & $0.1 \pm 0.07$ & Over whole graben (both faults) \\
\hline $\mathrm{CAF}$ & AF SS & 4 & 11.2 & $>75$ & SE & SE & Reverse & & & & \\
\hline $\mathrm{CAF}$ & WBS & 3 & 9.3 & $>75$ & NW & SE & Normal & $15.6 \pm 1$ & $0.9 \pm 0.2$ & $0.06 \pm 0.02$ & \\
\hline $\mathrm{CAF}$ & WBS & 4 & 11.3 & $40-60$ & NW & SE & Normal & $17.5 \pm 1.6$ & $4.4 \pm 0.7$ & $0.25 \pm 0.06$ & \\
\hline $\mathrm{CAF}$ & WBS & 5 & 12.7 & $>70$ & NW & SE & Normal & $17 \pm 0.9$ & $1.6 \pm 0.4$ & $0.1 \pm 0.03$ & \\
\hline $\mathrm{CAF}$ & CBS & 3 & 9.4 & $55-85$ & NW & SE & Normal & $15.6 \pm 1$ & $1.6 \pm 0.2$ & $0.1 \pm 0.02$ & \\
\hline $\mathrm{CAF}$ & CBS & 4 & 11.5 & $>65$ & SE & SE & Reverse & $17.5 \pm 1.6$ & $1.2 \pm 0.2$ & $0.07 \pm 0.02$ & \\
\hline $\mathrm{CAF}$ & CBS & 5 & 12.8 & $>70$ & NW & SE & Normal & $17 \pm 0.9$ & $1.5 \pm 0.4$ & $0.09 \pm 0.03$ & \\
\hline $\mathrm{CAF}$ & CBS & 6 & 14.6 & $50-80$ & NW & SE & Normal & $18.4 \pm 1.1$ & $4.1 \pm 0.5$ & $0.22 \pm 0.04$ & \\
\hline $\mathrm{CAF}$ & CBS & 7 & 16.4 & $40-70$ & NW & SE & Normal & $19.8 \pm 1$ & $2.9 \pm 1.1$ & $0.06 \pm 0.01$ & \\
\hline $\mathrm{CAF}$ & JS 1 & 7 & 16.2 & $>50$ & NW & SE & Normal & & & & \\
\hline $\mathrm{CAF}$ & JS 1 & 8 & 17.7 & & & & & $19.8 \pm 0.7$ & $1.1 \pm 0.2$ & $0.06 \pm 0.01$ & \\
\hline $\mathrm{CAF}$ & JS 1 & 9 & 18.8 & $>70$ & SE & SE & Reverse & $20.1 \pm 0.7$ & $3.3 \pm 0.3$ & $0.16 \pm 0.02$ & \\
\hline $\mathrm{CAF}$ & JS 1 & 10 & 20.5 & $>75$ & NW & SE & Normal & $20.1 \pm 0.3$ & $2.0 \pm 0.3$ & $0.1 \pm 0.01$ & \\
\hline Fus? & & DG01 & 22.5 & $65-70$ & SE & NW & Normal & & & & \\
\hline VF & & 1 & 4.7 & $55-85$ & SE & SE & Reverse & $12.6 \pm 0.5$ & $10.9 \pm 2.1$ & $0.86 \pm 0.2$ & \\
\hline VF & & 2 & 6.5 & $>60$ & SE & SE & Reverse & $13.9 \pm 0.6$ & $10.2 \pm 3.6$ & $0.73 \pm 0.29$ & \\
\hline VF & & 3 & 9 & $>70$ & SE & SE & Reverse & $16.4 \pm 0.8$ & $9.6 \pm 1.8$ & $0.59 \pm 0.14$ & \\
\hline VF & & 4 & 11 & & & SE & & $8.4 \pm 1.6$ & $3.6 \pm 1.8$ & $0.43 \pm 0.30$ & \\
\hline VF & & 5 & 12.3 & $50-80$ & SE & SE & Reverse & $17 \pm 0.9$ & $3.2 \pm 0.4$ & $0.19 \pm 0.03$ & \\
\hline VF & & 6 & 14 & $>70$ & SE & SE & Reverse & $17.9 \pm 0.6$ & $5.0 \pm 0.4$ & $0.28 \pm 0.03$ & \\
\hline VF & & 7 & 15.8 & $>70$ & NW & SE & Normal & $19.3 \pm 0.5$ & $2.8 \pm 0.4$ & $0.15 \pm 0.02$ & \\
\hline VF & & 8 & 17.3 & $60-80$ & SE & SE & Reverse & $19.3 \pm 0.5$ & $3.2 \pm 0.4$ & $0.16 \pm 0.01$ & \\
\hline VF & & 9 & 18.5 & $>70$ & SE & SE & Reverse & $19.8 \pm 0.4$ & $1.6 \pm 0.2$ & $0.08 \pm 0.1$ & \\
\hline VF & VF NS & 10 & 20.4 & $>75$ & SE & SE & Reverse & $20.1 \pm 0.3$ & $3.4 \pm 1.1$ & $0.17 \pm 0.06$ & Over whole graben (both faults) \\
\hline $\mathrm{VF}$ & VF SS & 10 & 20.4 & $>75$ & SE & SE & Reverse & & & & \\
\hline VF & & 11 & 22 & $55-85$ & SE & $\mathrm{SE}$ & Reverse & $20.2 \pm 0.3$ & $3.0 \pm 0.3$ & $0.15 \pm 0.02$ & \\
\hline $\mathrm{VF}$ & & $\mathrm{DG} 01$ & 22.5 & $60-80$ & SE & SE & Reverse & & & & Underlying structure \\
\hline VF & & 12 & 24.7 & $>60$ & SE & SE & Reverse & $20.3 \pm 0.3$ & $2.2 \pm 0.4$ & $0.06 \pm 0.01$ & \\
\hline VF & & 19 & 26 & $>60$ & SE & SE & Reverse & $20.1 \pm 0.3$ & $4.7 \pm 0.4$ & $0.24 \pm 0.02$ & \\
\hline $\mathrm{CF}$ & & 4 & 9.2 & $\sim 90$ & SE & NW & Normal & $14.4 \pm 1.7$ & $1.2 \pm 0.1$ & $0.08 \pm 0.01$ & \\
\hline $\mathrm{CF}$ & & 5 & 10.8 & $\sim 90$ & SE & NW & Normal & $16.9 \pm 2$ & $2 \pm 0.7$ & $0.12 \pm 0.02$ & \\
\hline $\mathrm{CF}$ & & 6 & 11.1 & $50-90$ & NW & NW & Reverse & $15.8 \pm 1.8$ & $8.1 \pm 2.6$ & $0.53 \pm 0.08$ & \\
\hline $\mathrm{CF}$ & & 7 & 13 & $50-70$ & SE & NW & Normal & $17.7 \pm 1.7$ & $15.1 \pm 3.5$ & $0.88 \pm 0.08$ & \\
\hline $\mathrm{CF}$ & & 8 & 14.3 & $45-75$ & SE & NW & Normal & $17.1 \pm 1.7$ & $15.9 \pm 4.5$ & $0.95 \pm 0.1$ & \\
\hline $\mathrm{CF}$ & & 17 & 15.3 & $65-90$ & SE & NW & Normal & $17.7 \pm 1.7$ & $15.1 \pm 3.5$ & $0.88 \pm 0.08$ & \\
\hline $\mathrm{CF}$ & & DG01 & 16.5 & $35-55$ & SE & NW & Normal & & & & \\
\hline $\mathrm{CF}$ & & 9 & 16.9 & $60-80$ & SE & NW & Normal & $18.6 \pm 1.4$ & $24 \pm 4$ & $1.3 \pm 0.1$ & \\
\hline $\mathrm{CF}$ & & 18 & 18.4 & $40-60$ & SE & NW & Normal & $18.9 \pm 1.2$ & $23.6 \pm 3.7$ & $1.28 \pm 0.08$ & \\
\hline $\mathrm{CF}$ & & 10 & 19.3 & $40-65$ & SE & NW & Normal & $19 \pm 1$ & $26.4 \pm 1.9$ & $1.33 \pm 0.08$ & \\
\hline $\mathrm{CF}$ & & 11 & 21.2 & $50-70$ & SE & NW & Normal & $19 \pm 1$ & $15.6 \pm 2.4$ & $0.8 \pm 0.1$ & \\
\hline $\mathrm{CF}$ & & 19 & 21.7 & $30-40$ & SE & NW & Normal & $18.9 \pm 1.1$ & $19.4 \pm 2.6$ & $1.05 \pm 0.05$ & \\
\hline $\mathrm{CF}$ & & 12 & 23.5 & & & & & $19.8 \pm 0.2$ & $0.4 \pm 0.2$ & $0.02 \pm 0.01$ & \\
\hline
\end{tabular}

Table 2) Offshore vertical displacement data from splays of the Awatere, Vernon, and Cloudy faults; including information on fault dip and vertical displacement rates. 
a)

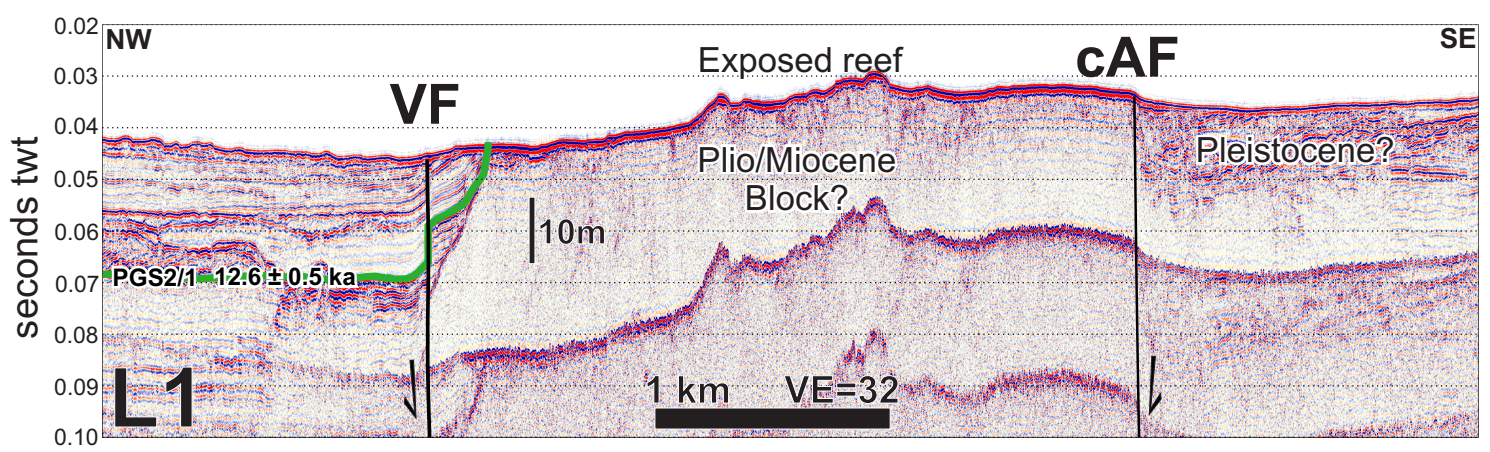

SE

b)

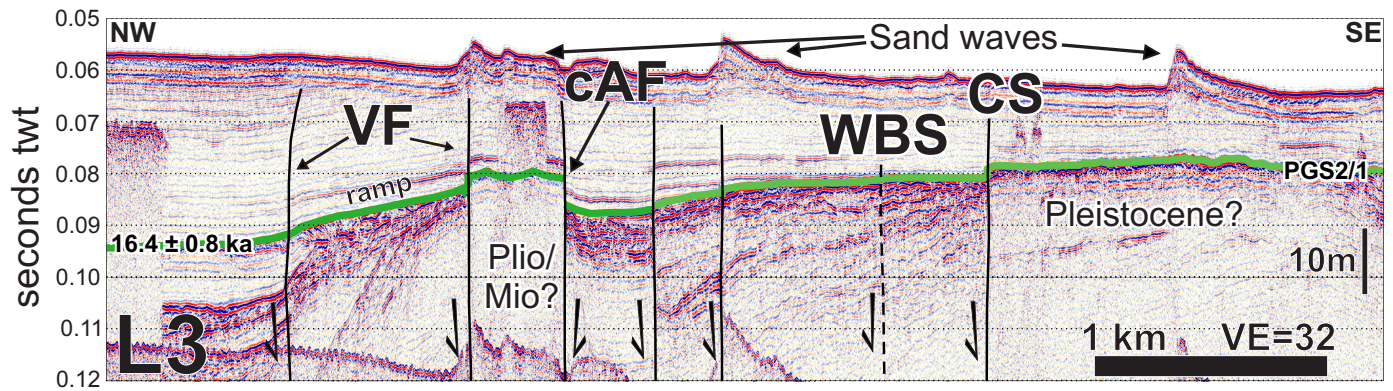

C)
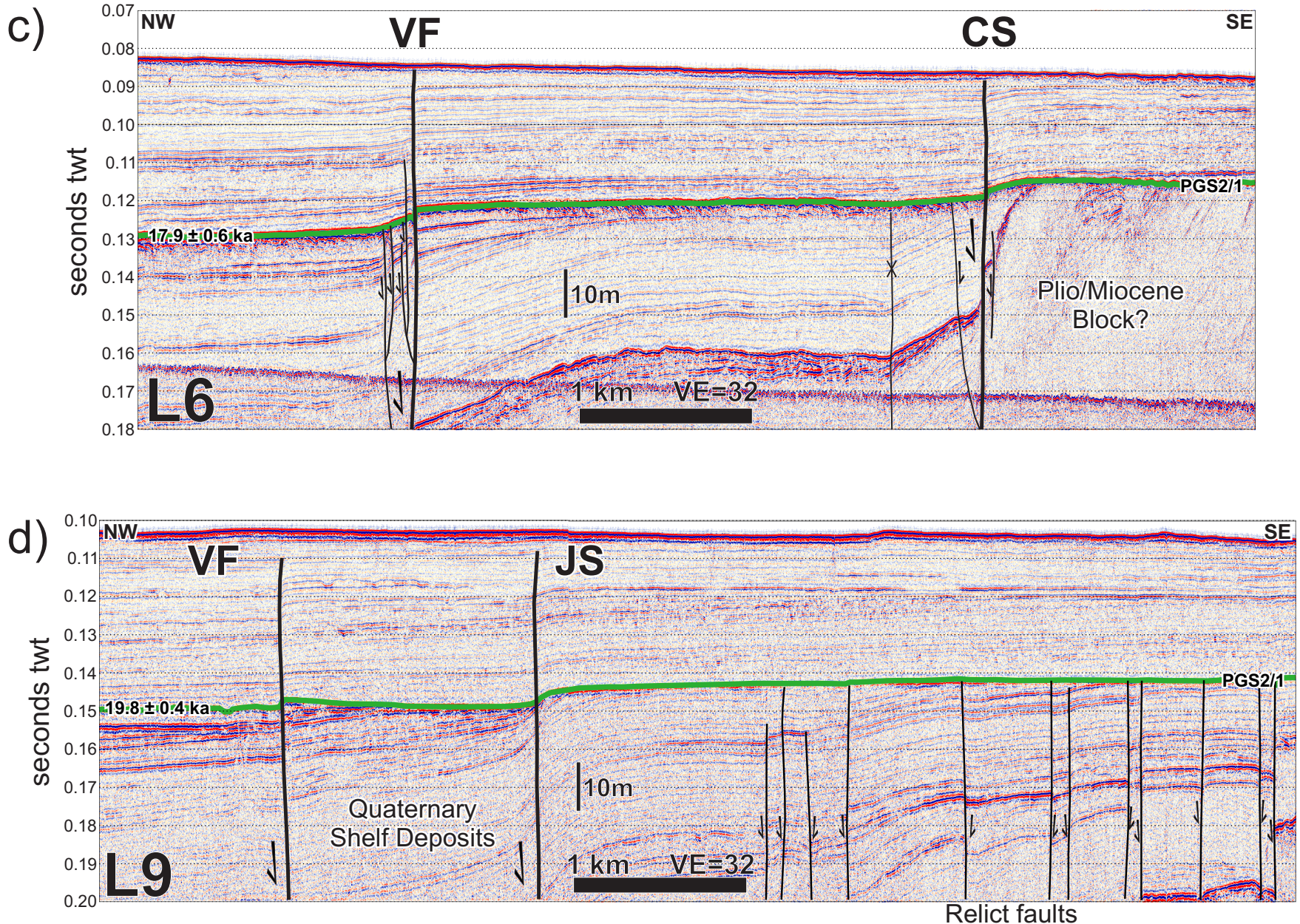

$\mathrm{SE}$

Figure 6) Boomer seismic profiles imaging the Vernon fault and splays of the Awatere fault. Shows slip on the Awatere fault in L1 get distributed into many splays in L3 and L6 then partitioned onto one splay in L9. The post glacial sediments are above the PGS2/1 erosional unconformity (green line). Locations of lines are presented in Fig. 1. VF= Vernon fault, $c A F=$ coastal A watere fault, WBS= White Bluffs splay, $C S=$ Castlebrae splay, JS= Jedburgh splay. 
Offshore, the coastal Awatere Fault terminates eastward into several smaller splays (Fig. 1). In the most westward boomer seismic lines (e.g., Line 1; Fig. 6a) the coastal Awatere Fault is the only fault imaged to the southeast of the Vernon Fault. On these lines I could not estimate late Quaternary vertical displacement rates on the coastal Awatere Fault because post glacial sediments were not imaged on both sides of the fault (eg. Fig. 6a). Further east, on line 3 (Fig. 6b) I measured a vertical displacement (NW side up) of the PGS2/1 unconformity on the coastal Awatere Fault (CAF) of $6.2 \pm$ $0.4 \mathrm{~m}$ along with smaller vertical displacements (SE side up?) on the White Bluffs (WBS) and Castlebrae (CS) splays of $0.9 \pm 0.2 \mathrm{~m}$ and $1.6 \pm 0.4 \mathrm{~m}$ respectively. From this I calculate a vertical displacement rate on the coastal Awatere Fault of $0.4 \pm 0.05 \mathrm{~mm} / \mathrm{yr}$ while the White Bluffs and Castlebrae splays have lower dip slip rates of $\sim 0.06$ and $0.1 \mathrm{~mm} / \mathrm{yr}$ respectively (Table 2). Still further east on line 4, the White Bluffs and Castlebrae splays record vertical displacement rates of $0.32 \pm$ $0.06 \mathrm{~mm} / \mathrm{yr}$ and $0.07 \pm 0.02 \mathrm{~mm} / \mathrm{yr}$, respectively. These vertical slip rates on the splays combined are higher than that on the terminating coastal Awatere Fault rate( $0.1 \pm 0.07 \mathrm{~mm} / \mathrm{yr})$ indicating that slip on the coastal Awatere Fault is partitioned eastward onto its horsetail splays. Here the vertical displacement rate on the White Bluffs splay is large where the rate on the Castlebrae splay is small; however, to the east of the termination of the White Bluffs splay (on line 6, Fig. 6c) the slip rate markedly increases to $0.22 \mathrm{~mm} / \mathrm{yr}$ on the Castlebrae splay (Table 2). A similar sharing of slip is observed in the area of overlap between the Castlebrae and Jedburgh splays still further to the east (line 9, Fig. 6d) which forms a releasing duplex-type structure at the termination of the coastal Awatere Fault. 
a)

b)
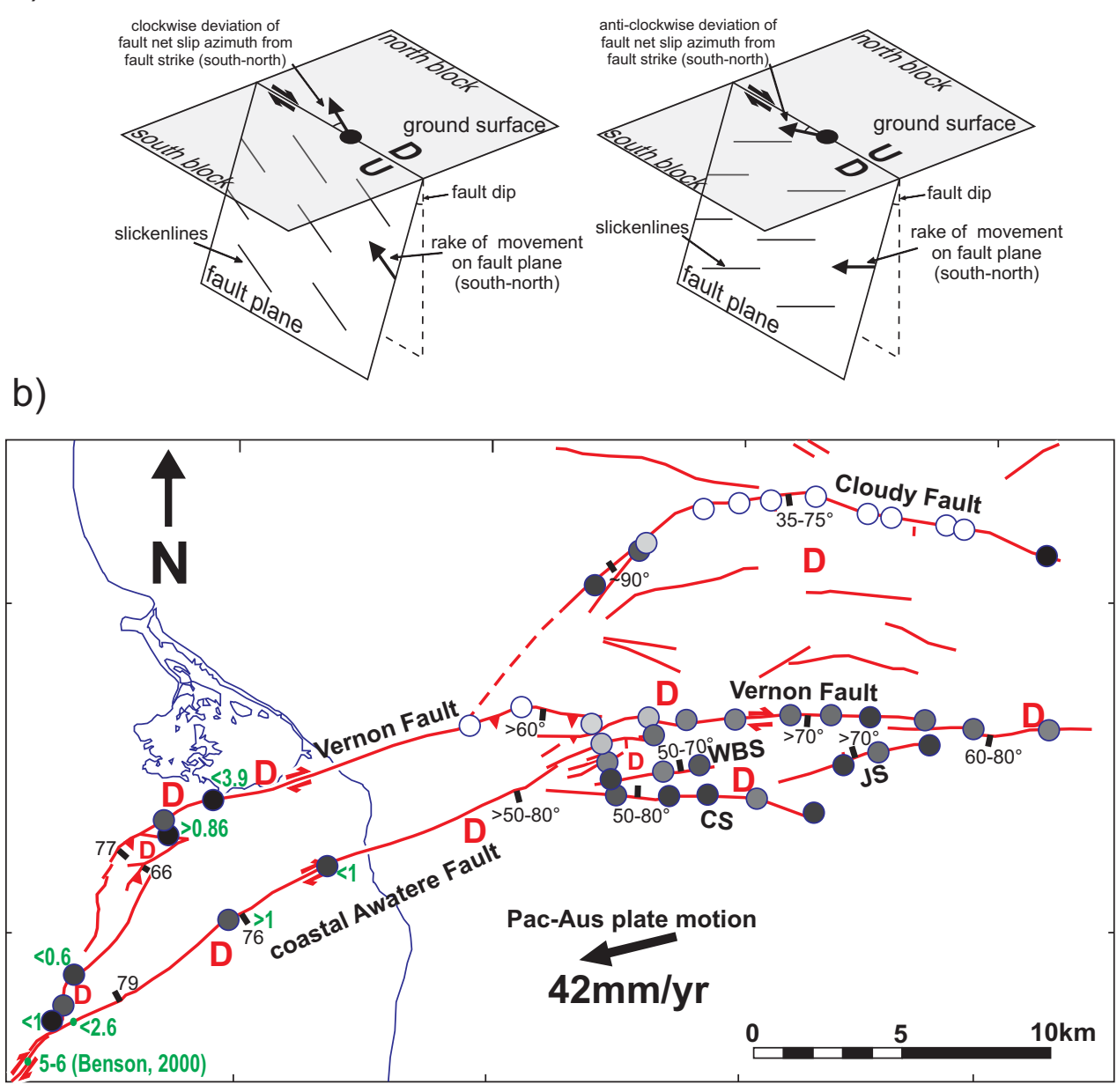

Vert. disp. rate

$(\mathrm{mm} / \mathrm{yr})$

$0.6+$

0.5-0.6

$0.4-0.5$

0.3-0.4

0.2-0.3

$0.15-0.2$

$0.1-0.15$

$0.05-0.1$

$<0.05$

Strike Slip rate

(mm/yr)

0.1

Fault, dip direction

c) and dip of fault

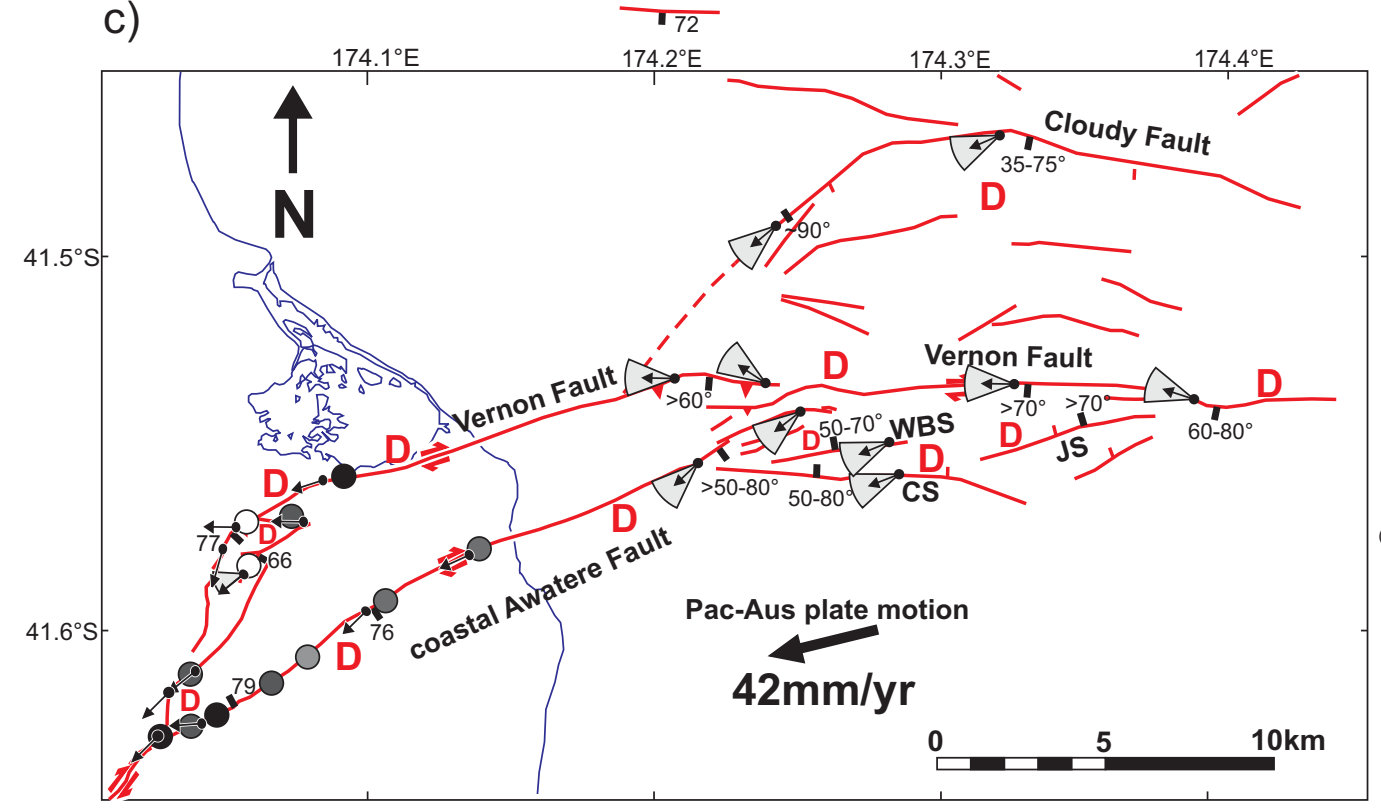

$\mathrm{H} / \mathrm{V}$ ratio

$0<2$

2-3

3-4

० 4-6

6-8

8-10

$10-20$

$>20$

Fault net slip azimuth (southern block-northern block)

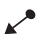

Quadrant containing fault net slip azimuth

(southern block-northern block) A

Figure 7 a) Schematic diagram showing the relationship between the dip-slip component of dextral faulting and the approximate trend of the fault slip azimuth on a dextral-oblique fault. $\boldsymbol{b})$ Map showing vertical-and dextral-slip rate data. c) Map showing $\mathrm{H} / \mathrm{V}$ ratios and inferred trends of fault slip vectors. The inferred fault slip azimuth is based on the approximate estimates of fault dip and dip slip rates. Vernon fault data is from Chapter 1, [this thesis], Cloudy fault vertical-slip rate data is from Pondard and Barnes, [2010]. 


\subsubsection{Neotectonics of the Vernon Fault}

About $1 \mathrm{~km}$ north of Dumgree Station, the Vernon Fault splays NNE-ward from the Awatere Fault and cuts through the Vernon Hills. In the northern Vernon Hills, several splays of the Vernon Fault bend NE and rejoin to form a single fault striking $\sim 075^{\circ}$. In the Vernon Hills, splays of the Vernon Fault bound narrow crustal blocks $<2 \mathrm{~km}$ in width (Fig. 1). About $3 \mathrm{~km}$ west of the Vernon splays, the Vernon Hills are $>60 \mathrm{~m}$ higher than to the east of the splays. Northwards, the Vernon fault bounds the southern margin of Big Lagoon along the northern flank of the Vernon Hills. Offshore, $3 \mathrm{~km}$ east of its intersection with the Cloudy Fault, the Vernon Fault bends clockwise to a strike of $\sim 090^{\circ}$ (Fig. 1). East of this offshore bend, the coastal Awatere Fault approaches the Vernon Fault from the south and splays clockwise in proximity to the more E-W striking Vernon Fault. The Vernon Fault terminates about $26 \mathrm{~km}$ east of the coast as it is not imaged in boomer seismic line 13 (Fig. 1). Exposures of the Vernon Fault splays in the Vernon Hills indicate fault dips of $>65^{\circ}$ to the SE. These data along with displacements of Quaternary landforms by Vernon fault splays in the Vernon Hills indicate that the splays have a reverse-slip component that is smaller than or equal to the accompanying dextral-slip component. Further east along the margin of Big Lagoon the strike-slip component is relatively larger $(\mathrm{H}: \mathrm{V}>8)$. Offshore, the Vernon Fault remains reverse in its dip-slip component imaged in the DG01 profile, dipping $60-80^{\circ}$ to the south and remains upthrown to the south (Table 2). In the boomer seismic lines 1-4, the Vernon Fault dips of $73-79^{\circ}$ to the SE. On these lines, offsets of the PGS2/1 unconformity indicate vertical displacement rates of $>0.40 \mathrm{~mm} / \mathrm{yr}$. Vertical displacement rates lessen eastward to $<0.28 \pm 0.03 \mathrm{~mm} / \mathrm{yr}$ to the east of line 4 (Table 2, Fig. 7a). The step-overs in the trace of the Vernon Fault in the offshore region (e.g., at line 10, Fig. 1) and the near vertical dip of the fault are consistent with the fault being a dominantly strike-slip structure everywhere along its length. 
Information regarding possible slip rates on the Vernon Fault can be obtained secondarily from an analysis of the slip-rate reduction on the Awatere Fault to the east of its bifurcation with the Vernon Fault. This indicates that a maximum of $5 \mathrm{~mm} / \mathrm{yr}$ has been partitioned northward onto the Vernon Fault. This estimate is a maximum because it does not account for any off-fault deformation that may accommodate some of the missing slip. Moreover, in Chapter 1 [this thesis] a maximum dextralslip rate estimate of $4.9 \mathrm{~mm} / \mathrm{yr}$ for the Vernon Fault was obtained near Big Lagoon by measuring the displacement of an active stream incised into the $\sim 30$ ka Do2 terrace. In the Vernon Hills a minimum dextral slip-rate estimate of $1.6 \mathrm{~mm} / \mathrm{yr}$ for Vernon Fault was obtained by measuring the displacement of an abandoned gully incised into a 120 ka terrace (Fig. 7a) on a splay of the Vernon Fault, a result that is more consistent with the paleoseismic data presented in Chapter 1 [this thesis].

\subsubsection{Neotectonics of the Cloudy Fault}

The Cloudy Fault is $23 \mathrm{~km}$ long and entirely submarine. It was identified in Pondard and Barnes [2010] in their analysis of the TAN0510 boomer seismic profiles and the DG01 multichannel seismic profile (Fig. 1). Pondard and Barnes [2010] measured late Quaternary vertical slip rates on the Cloudy Fault at 12 locations (Table 2) using the boomer seismic data. The fault is imaged furthest to the east in line 4 but may be present in lines 2 and 3, where it is possibly obscured or not imaged respectively (Fig. 1, Appendix E). I infer that the Cloudy Fault splays northward away from the Vernon Fault at depth at a strike of $\sim 044^{\circ}$. The Cloudy Fault gradually bends eastward to a strike of $\sim 105^{\circ}$ eleven kilometres northeast of its bifurcation from the Vernon fault near line 8 (Fig. 1). Vertical displacement rates on the fault are less than $\sim 0.12 \mathrm{~mm} / \mathrm{yr}$ in lines 4 and 5 but increase eastward of the bend to a maximum of $\sim 1.33 \mathrm{~mm} / \mathrm{yr}$ at line 10 . East of line 10 the vertical displacement rate lowers to $\sim 0.02 \mathrm{~mm} / \mathrm{yr}$ on line 12 , terminating $<2 \mathrm{~km}$ east of line 12 (Figs. 1, 7b, 
Table2). West of the bend in the boomer seismic lines 4 and 5 the Cloudy fault is approximately vertical. East of the bend, the DG01 seismic profile imaged the Cloudy Fault and suggests that it may be a listric oblique normal fault with a dip of $35^{\circ}-45^{\circ}$ to the SE (Fig. 8c). Nearby in the boomer seismic lines, the fault dips to the SE more steeply at $\sim 55-72^{\circ}$ (e.g. Lines 9 and 17 , Table 2 ). Hence relatively high vertical displacement rates are accompanied by shallower dips $\left(\sim 40-70^{\circ}\right)$ on the eastern part of the Cloudy fault and relatively low vertical displacement rates accompany approximately vertical fault dips on the western part (Fig. 7b, Table 2). The eastward rise in vertical displacement rate on the Cloudy Fault is most likely caused by the clockwise deflection in the strike of the fault to form a releasing bend at its eastern end.

Figure 8 a) Map showing the maximum possible dextral separation of the unconformable base of the Upton Formation against the older Torlesse Terrane basement, by splays of the Vernon Fault in the Vernon Hills (dashed blue line). b) Fault plane profile of the (here collapsed) Vernon Fault splays showing this offset and possible slip vectors depending on their $\mathrm{H}: \mathrm{V}$ ratio. The maximum the dextral separation of $3.5 \mathrm{~km}$ is a maximum estimate for total dextral-slip of the basement unconformity on the splays. c) The multi-channel seismic line DG01 (extent in Fig. 1), which images the Cloudy (CF), Vernon (VF), and Fuchia? (FF?) faults. The red lines on the faults indicate where the fault growth sequences are constrained to occur, with increasing displacement on the fault downwards. Stratigraphic picks are from Holdgate and Shaw [2001]; and Pondard and Barnes [2010]. 
8 a)
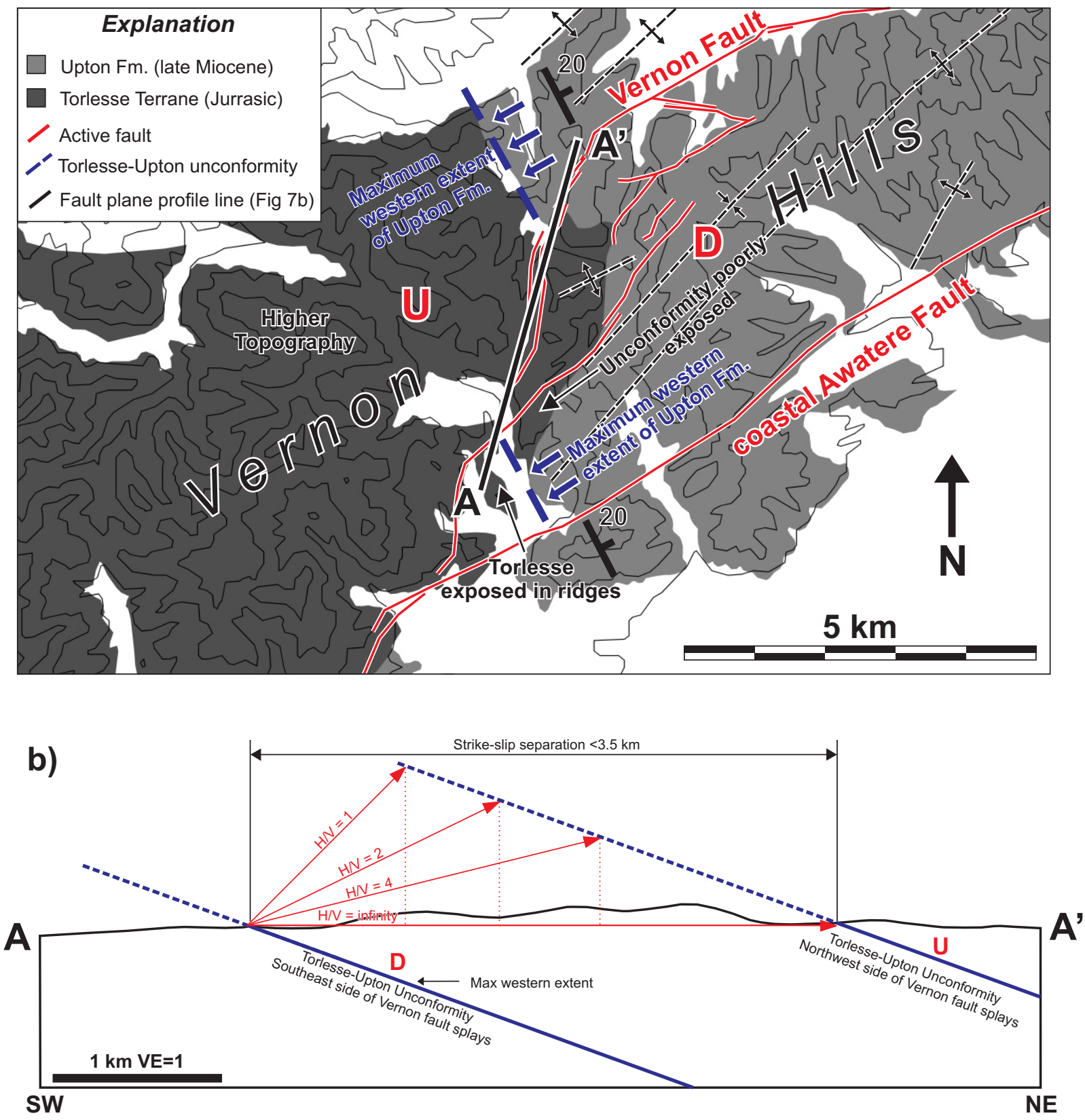

c)

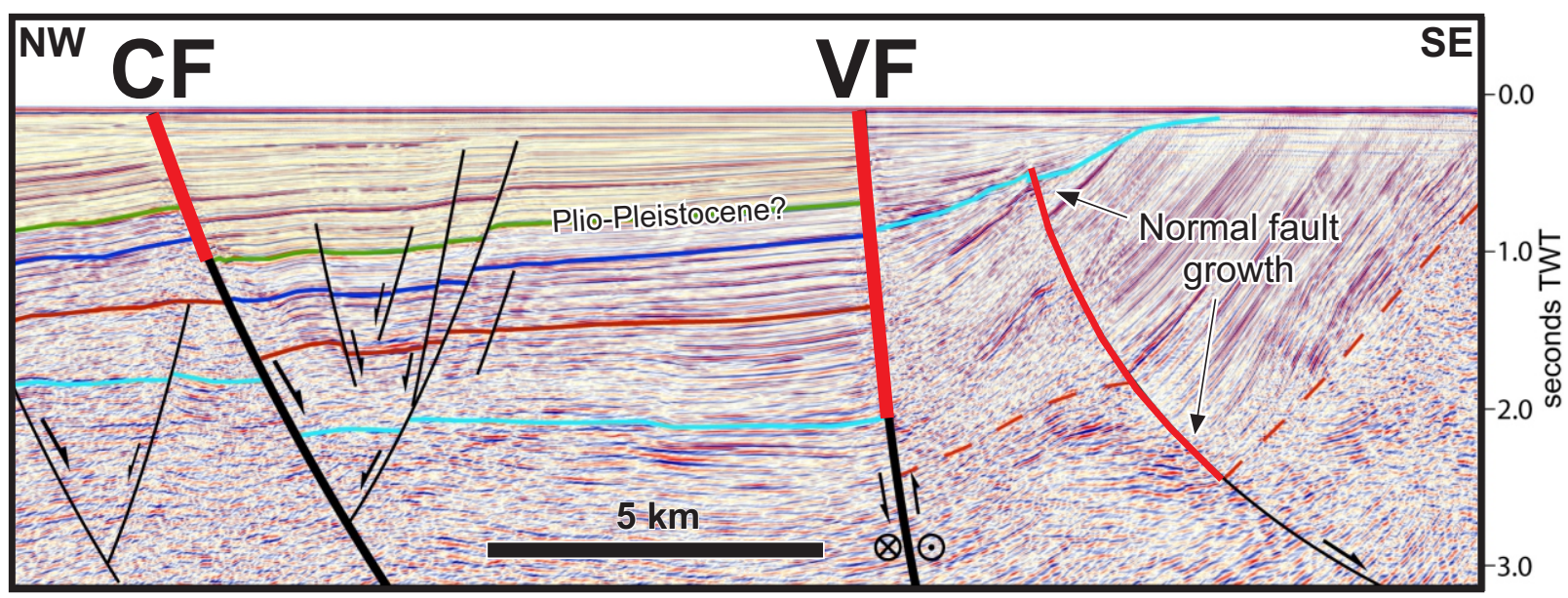




\subsection{Total Slip on the Awatere, Vernon and Cloudy Faults}

\subsubsection{Comparison of onshore finite slip on the Vernon and Awatere faults}

Past studies indicate that slip on the Awatere Fault was initiated subsequent to marine deposition of the Upton formation in the late Miocene (6.4-7.4 Ma) because a marine facies boundary within the formation is cut at a high angle by the fault [Little and Jones, 1998]. In addition, deposition of the Hillersden fan gravels at 2-3 Ma in the southern Wairau Valley (Fig. 1) from the uplifted block of the Awatere Fault to the SW suggests the fault was active by the mid to late Pliocene [Little and Jones, 1998]. The original coastal strand of the Awatere Fault that is inferred to have been active is the Fuchia Fault [Little and Jones, 1998]. About 35-45 km of dextral slip has been estimated to have accrued on the Fuchia Fault based on offset of the above mentioned facies boundary in the Upton Formation. This yields an inferred post late Miocene dextral slip rate of 5-7 mm/yr. Little and Jones [1998] inferred that the Fuchia Fault was abandoned sometime prior to the late Quaternary, because the fault cuts the Pliocene Starborough Formation but late Quaternary river terraces are unperturbed by the fault near the coast. Near White Bluffs at the coast, the coastal Awatere fault displaces an unconformity between an early Pliocene Starborough mudstone and the late Miocene Upton formation by $4 \mathrm{~km}$ [Little and Jones, 1998] (Fig. 1). Neither the Upton Formation nor the late Pliocene mudstone show stratigraphic evidence for activity on the coastal Awatere Fault during deposition; hence the inception of the fault must be less than the age of the Pliocene mudstone (about $5 \mathrm{Ma}$ ). 
Despite the Vernon Fault having a larger late Quaternary slip rate than the coastal part of the Awatere Fault (1.6-3.9 mm/yr vs. $\sim 1 \mathrm{~mm} / \mathrm{yr}$, respectively), it displaces the basal unconformity of the late Miocene Upton Formation $(<3.5 \mathrm{~km})$ with less finite dextral-slip than the coastal Awatere Fault separates the Pliocene mudstone near the coast $(4 \mathrm{~km})$. The basal contact of the Upton Formation against the Torlesse terrane has been mapped in the Vernon Hills [Little et al., 1998; Begg and Johnstone, 2000] (Fig. 8a). There, the unconformity's overlying strata in the Upton Formation dip $20^{\circ}$ to the SE [Little et al. 1998]. Although exposure of the unconformity is poor and the contact is only approximately mapped, one can estimate a maximum cumulative dextral separation of $3.5 \mathrm{~km}$ of the unconformity across the several splays of the Vernon Fault (Fig. 8a). Dip slip on the splays (up to the west) has no doubt contributed to some of this map separation, thus this is a maximum estimate of dextral-slip.

\subsubsection{Finite slip on the Vernon, Cloudy, and Fuchia faults in the offshore region}

The DG01 seismic profile images the Vernon and Cloudy faults (Fig. 8c). The age of the reflectors picked in the DG01 profile are from Holdgate and Shaw [2001], mainly based on correlation of offshore seismic reflectors to onshore stratigraphy and no borehole data [Uruski, 1992; Uruski, 1999]. These poorly constrained reflectors were correlated onto the DG01 seismic line by Pondard and Barnes [2010]. In this profile, the Cloudy Fault dips $40-60^{\circ}$ to the SE and exhibits $350-500 \mathrm{~m}$ of vertical displacement, as measured from the inferred Plio-Pleistocene and late Miocene reflectors (green line in Fig. 8c). The Cloudy Fault growth sequence is present above the inferred PlioPleistocene reflector (2-3 Ma), suggesting a post-Pleistocene inception age for the fault. 
The Vernon Fault has a reverse dip-slip sense and is steeper dipping than the Cloudy Fault. It displaces the inferred Miocene reflector $\sim 1.2 \mathrm{~km}$ vertically in a down to the NW sense (blue line in Fig. 8c). If this reflector is late Miocene in age, it corresponds to the top of the Upton Formation which has an age of 6.4-7.4 Ma based on its fossil content [Little and Jones, 1998]. Vernon fault growth has accumulated on the strata above this reflector, therefore the reflector constrains the maximum age of initiation of the fault (6.4-7.4 Ma). Younger interpretations for the age of the reflector (early Pliocene) are possible and discussed below.

About $3 \mathrm{~km} \mathrm{SE}$ of the Vernon Fault in the DG01 profile is a listric normal fault that could correlate to the abandoned Fuchia Fault (Fig. 8c). The fault dips $65-70^{\circ}$ and is downthrown to the SE. The fault's growth sequence is present between the light blue coloured reflector inferred to be late Miocene and the red dashed reflector because there is a larger dip-slip displacement of the red dashed reflector than that of the light blue reflector (Fig 8c). If the (light blue) reflector has a late Miocene age as presented in Pondard and Barnes [2010], the two reflectors (light blue and red) should bound the late Miocene Upton Formation. Hence the fault growth would have occurred during deposition of the Upton Formation and the fault must not be an offshore extension of the Fuchia Fault. This is because initiation of the Awatere Fault is constrained as occurring since deposition of the Upton Formation onshore [Little and Jones, 1998]. If the red dashed reflector is late Miocene instead, the unit below must be the Upton Formation and the fault growth must have occurred after the late Miocene, analogous to the initiation of the Awatere fault onshore [Little and Jones, 1998]. 


\subsection{Discussion}

\subsubsection{Rigid Block model}

Slip on the Awatere, Vernon, and Cloudy faults is not parallel to the Pac-Aus relative plate motion. Their patterns of slip illuminate our understanding of how deformation is distributed on the major faults across this eastern part of the MFS. Analysis of arrays of small faults exposed in the NW of the coastal Awatere Fault at White Bluffs in the Vernon block indicate that internal deformation of the fault blocks has taken place and minor faults contribute much less bulk strain than the major faults bounding these blocks [Little, 1995]. In this section I use a rigid block model to describe how the various fault blocks have interacted and slipped past one another and/or deformed internally at the NE end of the greater Awatere Fault system. This model initially ignores distributed internal deformation of the blocks but shortfalls in the rigid model provide insight into what types of internal deformation may actually be present.

I have divided the area into four blocks: the Wairau block, the Vernon block, the Cloudy block, and the Awatere block- each bounded by faults (Fig. 9a). For purposes of our reconstruction, I keep the Wairau block fixed and based on their late Quaternary slip, restore slip on the block-bounding faults to the south of the Wairau over an inferred hypothetical duration of $330 \mathrm{ka}$. The time span was to be arbitrarily large in order to clearly illustrate the late Quaternary deformation pattern. The reconstruction was made by restoring the pattern of local fault motions (rates and directions) at all locations along the faults where net slip data was available(Figs. $7 b, c)$. Variations in the azimuths of fault slip vectors allowed us to estimate the localities of the blocks' Euler poles of relative rotation 
with respect to the Wairau block and to back-slip and back-rotate the blocks to their configuration at 330 ka (assuming constant slip rates and direction over that period). Onshore, slickenline striations and 3D landform offsets allow the azimuths and rates of horizontal fault motion to be estimated at different points along the four faults. Offshore, block movement is estimated from the seismic sections in dip-slip only and provides only approximate estimates of spatially varying rates of horizontal divergence or convergence (Figs. 7b,c).

The reconstruction indicates the Vernon and Cloudy blocks are rotating anticlockwise with respect to the Wairau and Awatere blocks (Figs. 9b,c). This follows from the changing patterns of compression and extension along strike of the fault traces. In the reconstruction, gaps between the blocks indicate reverse-slip, whereas overlap indicates normal-slip (Fig. 9c). Anticlockwise rotation of the Vernon Block is supported by abnormally strike-slip fault slip azimuths slightly clockwise of the relative plate motion in the Vernon Hills in the west; and abnormally reverse fault-slip azimuths anticlockwise of the relative plate motion offshore in the east. Anticlockwise rotation of the Cloudy block is indicated by normal faulting transitioning to more strike-slip to the westwards across the bend in the Cloudy Fault, and also by the stronger reverse component westwards on the Vernon Fault offshore. The Awatere Block also appears to rotate anticlockwise relative to the Wairau Block. 
9 a)

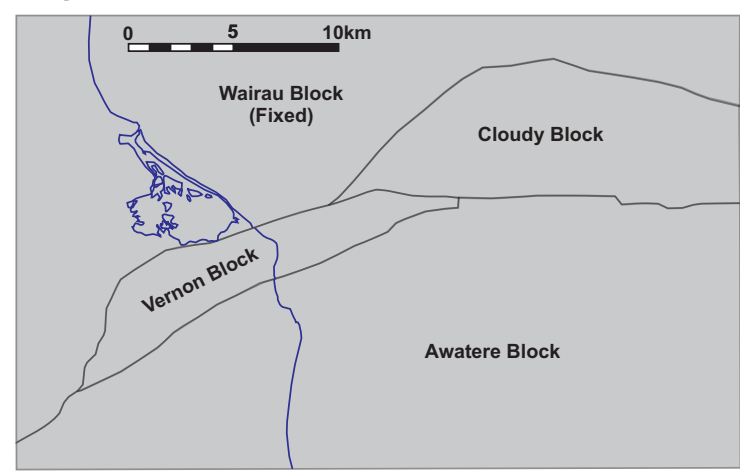

b)

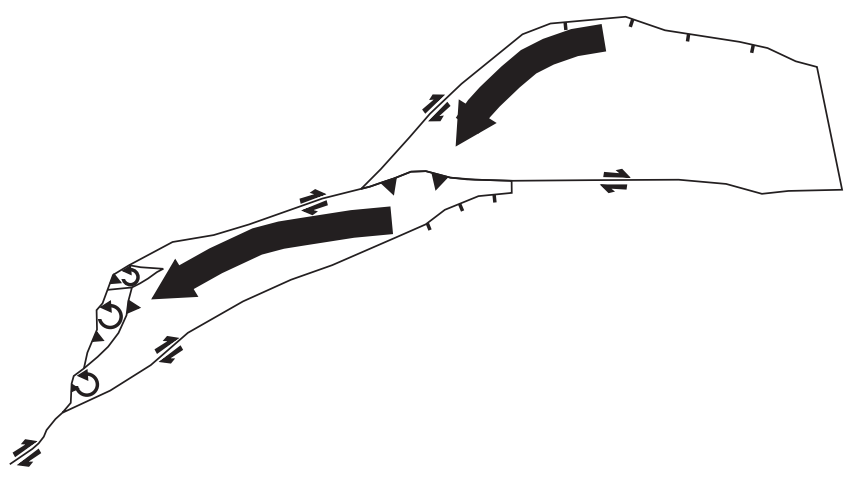

c)

Fault Slip Reconstruction (330ka)

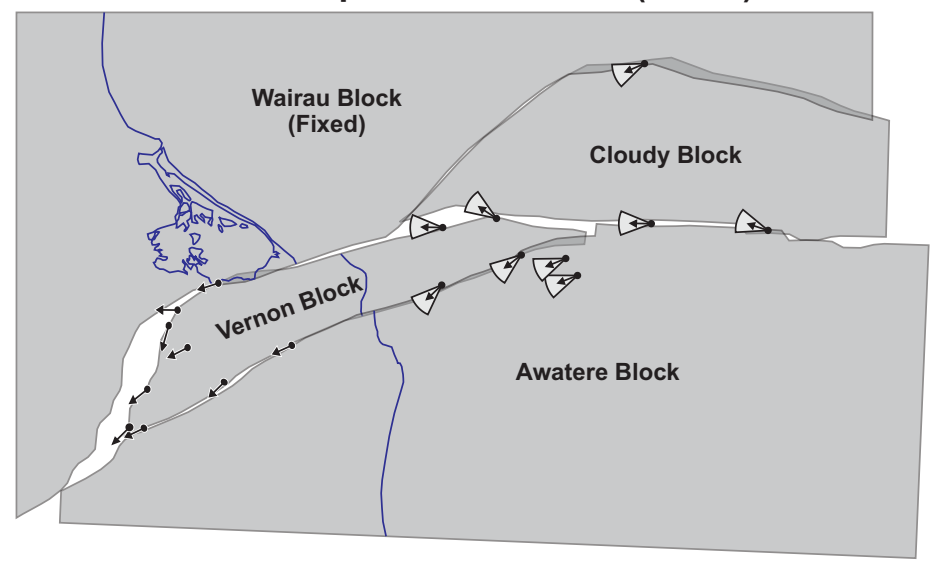

ڤ

Cloudy $\omega$ Wairau

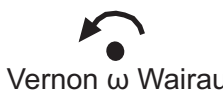

Awatere $\omega$ Wairau 
Figure 9a) Subdivision of the field area into the Wairau, Vernon, Cloudy, and Awatere Fault bounded blocks. b) Cartoon summary of block movements from the rigid block reconstruction in 9c. c) Hypothetical 330 ka rigid block reconstruction of the fault bounded blocks relative to the Wairau Block. Blocks were reconstructed using fault slip direction and rates (Figs. $7 b, c$ ). Divergence is indicated by block overlap (darker) and convergence is indicated by gaps (white). Arrows label inferred fault slip motion (Fig. 7c). Euler poles of rotation of the blocks relative to the Wairau block are presented as dots with arrows that show sense of rotation.

East of its bifurcation with the Vernon Fault, the coastal Awatere Fault has a slip rate of $\sim 1 \mathrm{~mm} / \mathrm{yr}$. This represents a decrease of $5 \pm 1 \mathrm{~mm} / \mathrm{yr}$ relative to the adjacent eastern Awatere Fault on the west side of that bifurcation. The Vernon Fault accommodates 1.6-4.9 mm/yr of dextral-slip adjacent to Big Lagoon. This slip could represent $23-120 \%$ of the $5 \pm 1 \mathrm{~mm} / \mathrm{yr}$ of missing slip rate from the eastern Awatere Fault. Any slip that may not be accounted for (up to $4.4 \mathrm{~mm} / \mathrm{yr}$ ) must be accommodated within the Vernon block, off of the splays I have mapped. Two possible mechanisms are suggested: hidden faulting within the Vernon block that do not produce surface expressions and distributed deformation in the form of folding with a NE trend, as observed in the Upton Formation in the Vernon Hills.

The Vernon Fault splays in the Vernon Hills have low late Quaternary slip rates of $<1.6 \mathrm{~mm} / \mathrm{yr}$ [Chapter 1, this thesis] compared to the maximum $5 \pm 1 \mathrm{~mm} / \mathrm{yr}$ of slip that may be partitioned from the eastern Awatere Fault northwards, indicating that there is missing tectonic deformation within the Vernon Hills. I infer that off-fault deformation must be occurring near the Vernon splays in the Vernon Hills to accommodate up to $4.6 \mathrm{~mm} / \mathrm{yr}$ missing slip. 
This missing slip is best explained by convergence in the Vernon Hills as shown in Fig 9c. I infer that the missing convergence in the Vernon Hills is partially accommodated by anticlockwise vertical-axis anticlockwise rotation of narrow Vernon splay-bound blocks, rotating in sympathy to the Vernon block movement with respect to the Wairau block (as shown in Fig. 9c). Any convergence that is not accommodated by vertical-axis rotation is probably accommodated by hidden splays proximal to the Vernon splays in the Vernon Hills and uplift of the Vernon Hills within the Wairau block to the west, probably by hidden reverse faults. The uplift to the west is apparent in Fig. 8a, where the topography in the Vernon Hills is higher to the west of the Vernon splays.

\subsubsection{Block Rotation Mechanisms}

Based on our reconstruction, the strongly curved geometry of the fault system is a driver of the likely above mentioned anticlockwise block rotations of the Vernon, Cloudy, and Awatere blocks relative to the Wairau block. The Cloudy and Vernon blocks are bounded by faults that define an unusual double restraining bend type structure [e.g. Cunningham and Mann, 2007]. In this network of strongly curved faults, the Vernon and Cloudy faults gradually bend clockwise eastwards.

Furthermore, at the widest scale all of the dextral-slip faults (including most obviously the inactive Fuchia Fault) appear to deflect clockwise between a strike of $\sim 055^{\circ}$ near their junction with the eastern Awatere Fault to $090-105^{\circ}$ near their eastern tips in the Cook Strait. In general this requires more compressional deformation in the west and extensional deformation to the east along the faults. The strong curvature and double restraining geometry of the faults may have led to them translating horizontally past each other about a vertical-axis rather than colliding and ramping over or under each other where the faults deflect into a strongly restraining geometry. I infer that it was 
more 'energetically efficient' to accommodate relative motion by vertical axis rotation rather than by significant compression and thickening across the restraining bends.

The cause of the eastward clockwise curvature of the fault system might have been the regional clockwise rotation of the NE part of the Marlborough Faults relative to the Pacific Plate and inland regions to the west during the Neogene [Lamb, 1988; Little and Roberts, 1997; Randall et al., 2011]. During the past $10 \mathrm{Ma}$, rocks in NE Marlborough have rotated clockwise about a vertical axis at a rate of $\sim 7^{\circ} /$ Ma near the eastern termination of the Clarence Fault (Fig. 1b) [Roberts, 1992; Roberts, 1995]. Little and Roberts [1998] argued that such clockwise rotation was largely localised to the eastern ends on the onshore Marlborough faults and caused a marked clockwise rotation in their eastern ends as a function of time, although this view was not shared by Lamb et al. [2011].

\subsubsection{Evolution of the Vernon, Awatere and Cloudy faults}

The Fuchia Fault is the original eastern extension of the Awatere Fault. Little and Jones [1998] estimated that 35-45 km of dextral slip accrued on this fault after 6.4-7.4 Ma, (Fig. 10a). Based on the fact it cuts Pliocene rocks but has no late Quaternary offsets, the Fuchia Fault is inferred to have been abandoned in the Plio-Pliestocene. A possible continuation of the Fuchia Fault is imaged offshore, on seismic profile DG01, where it dips $65-70^{\circ}$ to the SE with normal dip-separation (Fig. 8c). Age constraints on the offset reflectors in the DG01 profile are poor, but could support the possibility that fault growth occurred within strata younger than the late Miocene, hence correlating to the Fuchia Fault onshore. Little and Roberts [1997] argued that clockwise rotation of the near coastal Fuchia Fault relative to the eastern Awatere Fault further inland was the reason for the 

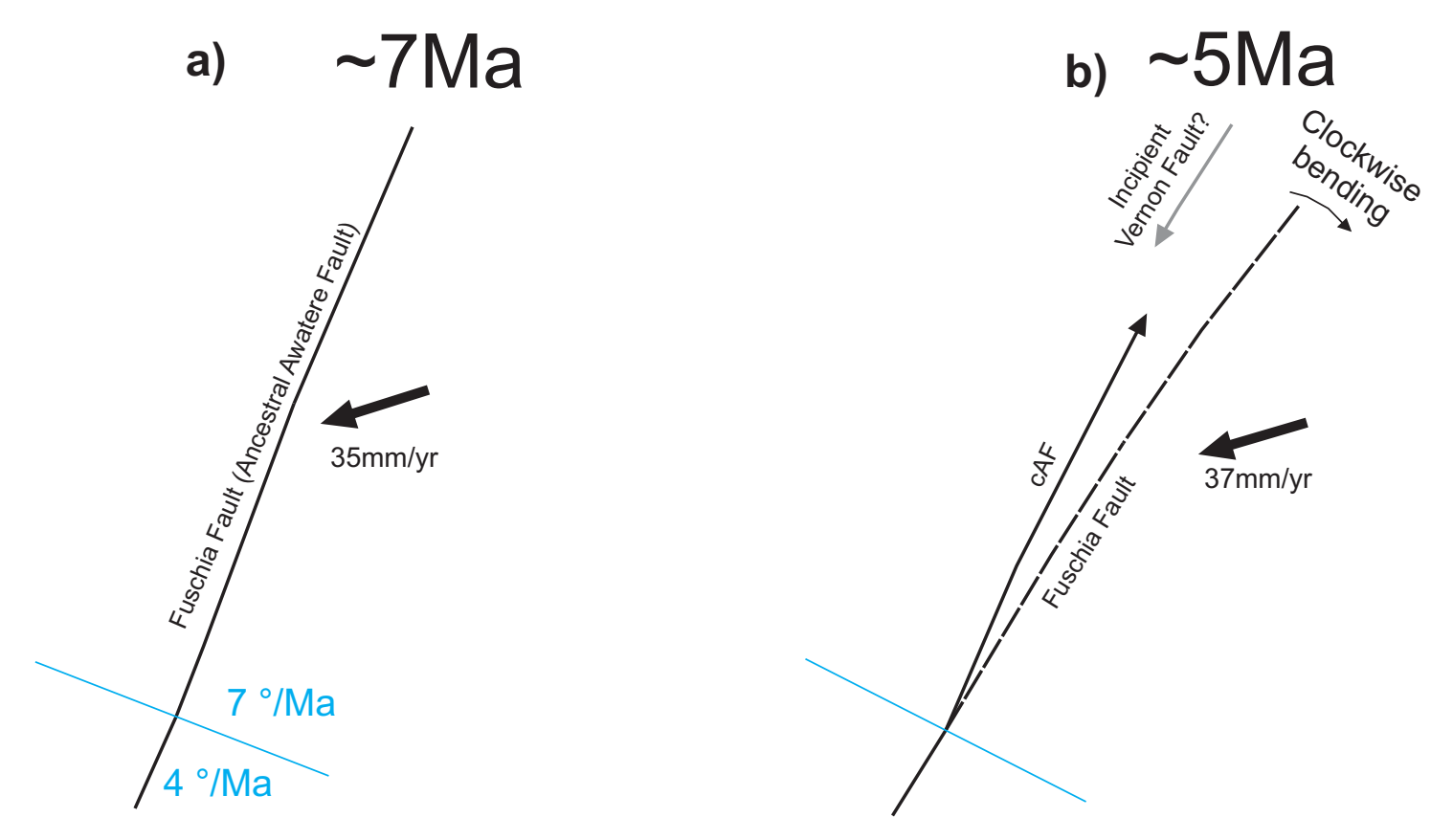

c) $5-1 \mathrm{Ma}$

d) $\quad<1 \mathrm{Ma}$
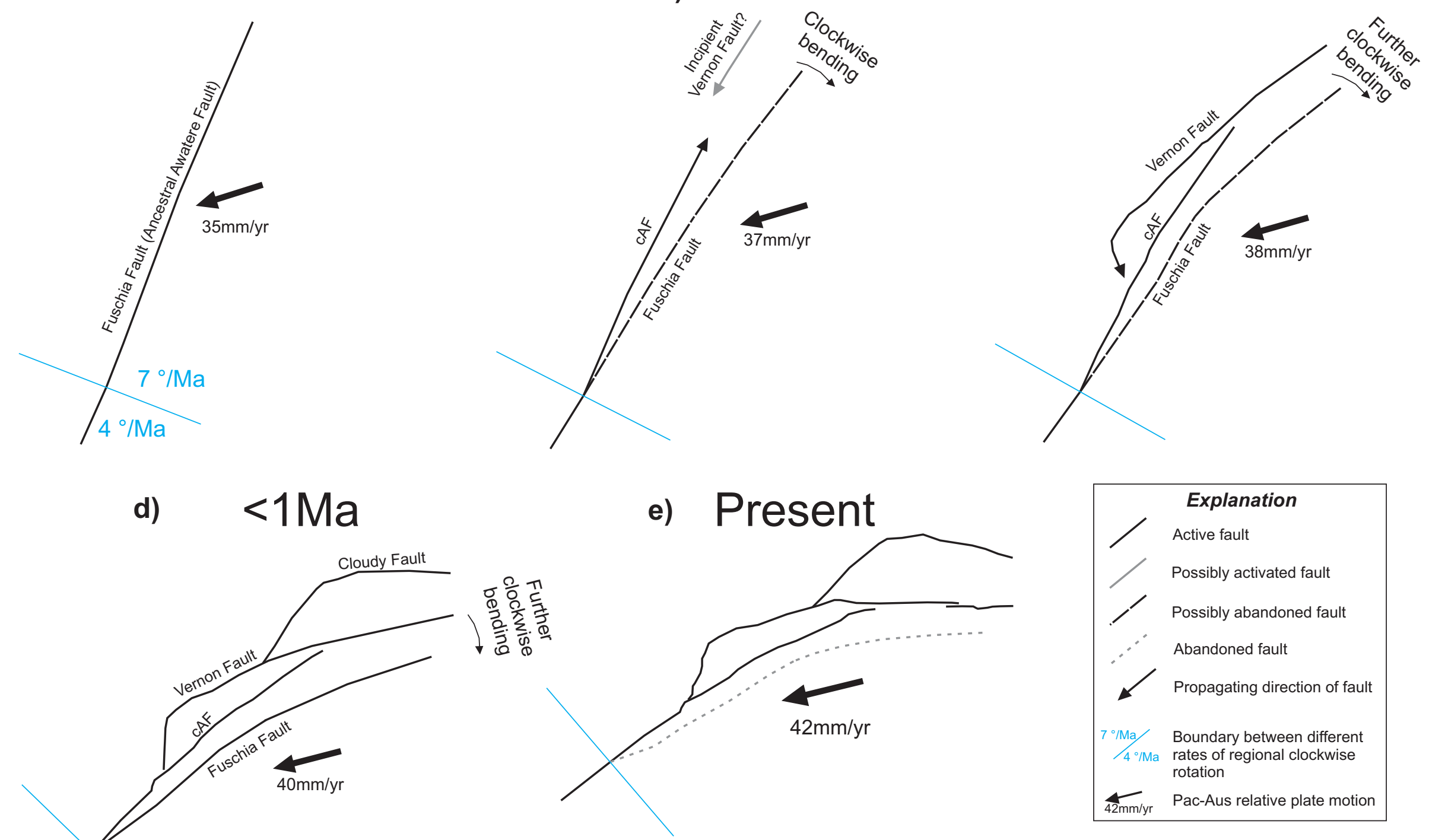

Figure 10 a-e) Stages of fault growth, bending, and abandonment of the faults within the fault Vernon-Awatere-Cloudy network since inception of the Awatere fault. Also shows the boundary of clockwise regional rotation indicated by paleomagnetic rotations of rocks NE Marlborough [Lamb, 1988; Little and Jones, 1997; Randall et al., 2011] (in blue). 
misalignment and abandonment of the Fuchia Fault. According to this model the clockwise misalignment and death of the Fuchia Fault led to the initiation of the active coastal Awatere Fault in the Plio-Pleistocene [Little and Jones, 1998].

Onshore the Vernon Fault is inferred by us to be younger than the coastal Awatere Fault. The age of the coastal Awatere Fault is constrained to be younger than the early Pliocene mudstone ( $5 \mathrm{Ma})$ near White Bluffs (Fig. 1). During this time the coastal Awatere Fault is estimated to have accrued a maximum dextral displacement of $\sim 4 \mathrm{~km}$. The age of the Vernon Fault is poorly constrained to be younger than the late Miocene Upton Formation (7.4-6.4 Ma) in the Vernon Hills (Fig. 8c). During this time the fault is estimated to have accrued a maximum dextral displacement of $3.5 \mathrm{~km}$. Using late Quaternary dextral-slip rates of 1.6-4.9 mm/yr on the Vernon Fault and $\sim 1 \mathrm{~mm} / \mathrm{yr}$ on the coastal Awatere Fault, it would take a maximum of 2.2 Myr for the Vernon Fault and 4 Myr for the Awatere Fault to accumulate their respective total dextral displacements. Although I admit that these ages are inaccurate as the slip rates could have changed since fault initiation, I can infer that the coastal Awatere Fault is most likely older than the Vernon Fault. The youth of the Vernon Fault through the Vernon Hills is also consistent with its immature pattern of its several short $(<7 \mathrm{~km})$ surface traces that are not well linked in the Vernon Hills. Early in the evolution of a fault, slip is commonly thought to be partitioned between short, poorly oriented fault splays. As slip accumulates however, splays eventually link up and coalesce and are eventually bypassed by a single throughgoing fault [Wesnousky 1988].

I infer that the age of the Vernon Fault is older offshore than it is offshore. The age is poorly constrained in the DG01 seismic section as having a fault growth sequence younger than the late Miocene (7.4-6.4 Ma, Fig. 8a). The Vernon fault has accumulated $\sim 1.2 \mathrm{~km}$ of vertical displacement 
since its initiation, measured on the red reflector in Fig. 8c. Using late Quaternary vertical slip rate estimates of $0.05-0.23 \mathrm{~mm} / \mathrm{yr}$ on the Vernon Fault (lines 10-12, Table 2), it would take a minimum of 5.2 Myr for the Vernon Fault to accumulate its total vertical displacement, longer than required in the Vernon Hills as stated above. From this observation I infer that the Vernon Fault is likely to be older offshore than it is onshore in the Vernon Hills, and could have originally propagated westwards through time. I propose that the Vernon Fault could have originated as a left-stepping eastern segment of the coastal Awatere Fault that subsequently propagated westward, creating overlap with the coastal Awatere Fault (Figs. 10b). Ultimately the western end of the Vernon Fault rejoined the coastal Awatere Fault to form its current intersection point, possibly by reactivating some preexisting basement fault that was striking NNE (Fig. 10c).

The Cloudy Fault is inferred to have the youngest age of initiation of the 3 splays at the eastern end of the Awatere fault. The fault is constrained in the DG01 line (Fig. 8a) as having a fault growth sequence younger than the inferred Plio-Pleistocene reflector (2-3 Ma). Comparatively the Vernon Fault's growth sequence appears to be older than the Cloudy Faults in the DG01 line (Fig. 8a). The Cloudy Fault has accumulated 350-500 m of vertical displacement since its initiation, measured on the green reflector on Fig. 8a. Using late Quaternary vertical slip rate estimates of 0.8-1.3 mm/yr (lines 9, 17; Table 2), it would take a maximum of $0.6 \mathrm{Myr}$ for the Cloudy fault to accumulate its total vertical displacement, younger than the Vernon Fault offshore as stated above. Hence the Cloudy Fault is the youngest of the faults within the fault network and it has apparently formed by stepping northward from the Vernon Fault (Fig. 10d).

Together, these observations suggest that the eastern part of the fault system has been stepping northward during its evolution as new faults propagate into the more northern regions and older 
faults die out to the south (Fig. 10). Perhaps this progression has been triggered by the clockwise rotation of the NE ends of the coastal Marlborough Faults with respect to more inland regions. This scenario is similar to the suggestion that clockwise rotation of NE coastal Marlborough may have caused the abandonment of the Fuchsia Fault and initiation of the coastal Awatere Fault which stepped further northwards [Little and Jones, 1998]. The southward bending of the eastern ends of the Awatere, Vernon, and Cloudy Faults causes their curved geometry, which in turn causes the blocks to translate and rotate past one another instead of converging against each other as shown in the block model (Figs. 9b,c). The clockwise bending of the eastern tips of the Marlborough Faults deflect these faults southward and promotes a mismatch between the NNE striking NIDFB and the MFS across the Cook Strait (Fig. 1b). The newly activated eastern strands in the Awatere Fault System may be aligning with the NIDFB through time, in particular the Wellington Fault. 


\subsection{Conclusions}

East of its bifurcation with the Vernon Fault, the coastal Awatere Fault has a slip rate of $\sim 1 \mathrm{~mm} / \mathrm{yr}$. This represents a decrease of $5 \pm 1 \mathrm{~mm} / \mathrm{yr}$ relative to the adjacent eastern Awatere Fault on the west side of that bifurcation. The coastal Awatere Fault is mainly dextral, but acquires a normal component offshore where there is a releasing step-over near the eastern termination of the fault. The eastern tip of the coastal Awatere Fault is diffuse, splaying onto the Vernon Fault offshore. The Vernon Fault accommodates 1.6-4.9 mm/yr of dextral-slip adjacent to Big Lagoon. This slip could represent $23-120 \%$ of the $5 \pm 1 \mathrm{~mm} / \mathrm{yr}$ of missing slip rate from the eastern Awatere Fault. I account for any possible discrepancy by proposing that any missing slip may be accommodated by hidden faults or slight folding on a NE axis within the Vernon block.

Blocks which are bounded by the Awatere, Vernon, and Cloudy faults are rotating anticlockwise with respect to their surrounding blocks. The rotations are indicated by changes of late Quaternary slip motion and strike from fault to fault, especially the lack of marked compression along the apparent restraining bends in the Vernon and Cloudy faults. The anticlockwise rotations of the fault bounded blocks are probably a response to the strong curvature of the Vernon and Cloudy faults, causing the fault bounded blocks to slide against one another instead of colliding with each other resulting in thickening of the crust.

A slip rate shortage of $<2.3 \mathrm{~mm} / \mathrm{yr}$ is present on splays of the Vernon fault in the Vernon Hills (relative to the eastern Awatere Fault). This slip shortage could be in part accommodated by the anti-clockwise rotation of the Vernon block with respect to the Wairau block as well as the 
anticlockwise rotation of narrow Vernon splay-bounded blocks in the Vernon Hills in sympathy to the larger rotation of the Vernon block to the east. The slip also could also be accommodated by hidden splays proximal to the Vernon splays in the Vernon Hills or hidden faults to the west, uplifting the Vernon Hills.

The onshore Vernon Fault through the Vernon Hills is probably younger than the coastal Awatere Fault, as indicated by its smaller total slip of $<3.5 \mathrm{~km}$ in conjunction with its higher late Quaternary slip rate of 1.6-3.9 mm/yr. I propose that subsequent to the early Pliocene, the Vernon Fault propagated westwards from the offshore region while the coastal Awatere Fault was propagating eastwards from the onshore region. The linkage of these overlapping segments is along a NNE striking splay, perhaps an older fault reactivated in the basement. Here the Vernon Fault cut through the Vernon Hills to join with the Awatere Fault, possibly <2.6 Ma. The Cloudy Fault was initiated after the Vernon Fault, sometime after the Plio-Pleistocene (2-3 Ma). The overall north-stepping pattern of the Awatere fault system evolution may be a result of the eastern extent of the faults being progressively rotated clockwise and bent southwards. This misalignment led to the above mentioned sequential activation of the coastal Awatere Fault, then the Vernon Fault, then the Cloudy Fault in the last $7 \mathrm{Ma}$. 


\section{Thesis Conclusions}

This thesis utilises late Quaternary slip measurements on splays of the Vernon, coastal Awatere and Cloudy faults in order to understand the kinematics, evolution, and paleoseismicity of this complex fault network at the eastern end of the Marlborough Fault System. First, I focused on the Vernon Fault, measuring late Quaternary slip data and determining paleoseismic records both onshore and offshore. These data were used to assess the kinematics and paleoseismicity of the Vernon Fault, as well as constrain how dip slip on the fault is affecting the adjacent Big Lagoon. Second, I focused on the whole fault network, analysing and collating late Quaternary and finite slip data from the Vernon, Awatere, and Cloudy faults. These data were used to assess the late Quaternary kinematics and the evolution of the fault network. Based on these new data, I present the following conclusions:

1) The Vernon Fault partitions up to $1.6-4.9 \mathrm{~mm} / \mathrm{yr}$ of late Quaternary strike-slip NNE from its birfurcation with the eastern Awatere Fault which accommodates $6 \pm 1 \mathrm{~mm} / \mathrm{yr}$. The coastal Awatere Fault bifurcates from this junction, partitioning $\sim 1 \mathrm{~mm} / \mathrm{yr}$ of strike-slip eastwards.

2) Although the strike of the Vernon Fault varies by $\sim 90^{\circ}$, it is dextral-reverse along its length. The fault is mainly dextral at most localities $(H: V$ of $0.5-100)$. In general the fault has a reverse slip component, dipping steeply $\left(>60^{\circ}\right)$ and upthrown to the SE.

3) The coastal Awatere Fault is predominantly strike-slip onshore $(H: V>6)$ with an approximately vertical dip. Motion may become more normal towards the offshore, where it dips $\left(55-85^{\circ}\right)$ and is downthrown to the SE. Eastwards of the termination of the main splay of the coastal Awatere fault, multiple splays bifurcate eastward in a horse-tail structure. 
4) Based on a rigid block fault slip reconstruction, I propose anticlockwise vertical axis rotation of the Vernon, Cloudy, and Awatere blocks with respect to the Wairau block. I propose that this rotation is caused by the unique curvature of the faults themselves, and the fault network as a whole.

5) Faulting on Vernon splays in the Vernon Hills is dextral-reverse with an equal or higher component of strike-slip to dip-slip. A shortfall of up to $3.6 \mathrm{~mm} / \mathrm{yr}$ is apparent in the faulting through the Vernon Hills, probably accommodated by: anticlockwise vertical axis rotation of the Vernon block relative to the Wairau block along with rotating smaller Vernon splaybounded blocks in sympathy to this larger movement and/or unsighted faulting proximal to and west of the Vernon splays.

6) The Vernon Fault last ruptured $3.3 \pm 0.6 \mathrm{ka}$ and it has a recurrence interval of 3-4 ka. The onshore and offshore paleoseismic records correlate well with only one earthquake missing from the onshore record, probably due to an $\sim 8000$ ka hiatus in the trench site. This study further indicates the method of using high resolution offshore seismic data for paleoearthquake analysis is reliable.

7) Paleoearthquake patterns have emerged on the faults within the fault network, with the Vernon, Awatere, and Cloudy faults rupturing in temporal clusters. This could be due to mutual rupturing of separate faults during an earthquake or triggering of another earthquake within the fault network soon after the initial one.

8) Splays within the fault network appear to step northwards through time since the Awatere Fault's initiation, after the late Miocene. This stepping may be caused by constant clockwise 
rotation of the eastern end of the Awatere Fault zone, causing misalignment and abandonment of older faults and the initiation of new faults. 


\section{References}

Barka, A. A. and Kadinsky-Cade, K. (1988). "Strike-slip fault geometry in Turkey and its influence on earthquake activity." Tectonics 7(3): 663-684.

Barnes, P. M. and Pondard, N. (2010). "Derivation of direct on-fault submarine paleoearthquake records from high-resolution seismic reflection profiles: Wairau Fault, New Zealand." Geochem. Geophys. Geosyst. 11(11): Q11013.

Bayarsayhan, C., Bayasgalan, A., Enhtuvshin, B., Hudnut, K. W., Kurushin, R. A., Molnar, P. and Ölziybat, M. (1996). "1957 Gobi-Altay, Mongolia, earthquake as a prototype for southern California's most devastating earthquake." Geology 24(7): 579-582.

Begg, J. G. and Johnston, M. R. (2000). "Geology of the Wellington area." Institute of Geological \& Nuclear Sciences 1:250000 geological map 10: 1 sheet $+64 p$.

Benson, A. M. (2000). Late Quarternary deformation and paleoseismicity on the easternmost part of the Awatere Fault, South Island, New Zealand. Wellington, Victoria University. M. Sc. Thesis.

Benson, A. M., Little, T. A., Van Dissen, R. J., Hill, N. and Townsend, D. B. (2001). "Late Quaternary paleoseismic history and surface rupture characteristics of the eastern Awatere strike-slip fault, New Zealand." Geological Society of America Bulletin 113(8): 1079-1091.

Berryman, K. R., Beanland, S., Cooper, A. F., Cutten, H. N., Norris, R. J. and Wood, P. R. (1992). "The Alpine Fault, New Zealand: variation in Quaternary structural style and geomorphic expression." Annales Tectonicae 6(Suppl.): 126-163.

Bronk Ramsey, C. (2001). "Development of the radiocarbon calibration program OxCal." Radiocarbon 43(2A): 355-363.

Castelltort, S., Pochat, S. and Van Den Driessche, J. (2004). "Using T-Z plots as a graphical method to infer lithological variations from growth strata." Journal of Structural Geology 26(8): 1425-1432.

Clark, K. J., Hayward, B. W., Cochran, U. A., Grenfell, H. R., Hemphill-Haley, E., Mildenhall, D. C., Hemphill-Haley, M. A. and Wallace, L. M. (2011a). "Investigating subduction earthquake geology along the southern Hikurangi margin using palaeoenvironmental histories of intertidal inlets." New Zealand Journal of Geology and Geophysics 54(3): 255-271. 
Clark, K. J., Van Dissen, R. J., Litchfield, N. J., Bartholomew, T. D. and Little, T. A. (2011b). "The Vernon Fault: onshore paleoseismicity, constraints on slip rate, and contribution to Holocene tectonic subsidence of Big Lagoon, South Island, New Zealand " GNS Science Report 2001/42.

Clement, A. J. H., Sloss, C. R. and Fuller, I. C. (2008). Holocene eustatic sea-level change in New Zealand. Geosciences. TePapa, Wellington, Geological Society of New Zealand. Miscellaneous Publication: $\mathrm{p} 19$.

Cochran, U., Berryman, K., Zachariasen, J., Mildenhall, D., Hayward, B., Southall, K., Hollis, C., Barker, P., Wallace, L., Alloway, B. and Wilson, K. (2006). "Paleoecological insights into subduction zone earthquake occurrence, eastern North Island, New Zealand." Geological Society of America Bulletin 118(9-10): 1051-1074.

Cowgill, E., Yin, A., Arrowsmith, J. R., Feng, W. X. and Shuanhong, Z. (2004). "The Akato Tagh bend along the Altyn Tagh fault, northwest Tibet 1: Smoothing by vertical-axis rotation and the effect of topographic stresses on bend-flanking faults." Geological Society of America Bulletin 116(11-12): 1423-1442.

Cunningham, W. D. and Mann, P. (2007). "Tectonics of strike-slip restraining and releasing bends." Geological Society, London, Special Publications 290(1): 1-12.

Eden, D. N. (1989). "River terraces and their loessal cover beds, Awatere River Valley, South Island, New Zealand." New Zealand Journal of Geology and Geophysics 32: 487-498.

Eden, D. N. and Hammond, A. P. (2003). "Dust accumulation in the New Zealand region since the last glacial maximum." Quaternary Science Reviews 22(18-19): 2037-2052.

Grapes, R. and Downes, G. (1997). "The 1855 Wairarapa, New Zealand, earthquake : Analysis of historical data." Bulletin of the New Zealand National Society for Earthquake Engineering 30(4): 271368.

Harris, R. A., Dolan, J. F., Hartleb, R. and Day, S. M. (2002). "The 1999 İzmit, Turkey, Earthquake: A 3D Dynamic Stress Transfer Model of Intraearthquake Triggering." Bulletin of the Seismological Society of America 92(1): 245-255.

Hill, N., Little, T. A., Van Dissen, R. J., Benson, A., Townsend, D. B. and McLea, B. (2001). A refined paleoseismic history of the eastern section of the Awatere fault, New Zealand, based on results from a 2nd trench excavated near Lake Jasper New Zealand Earthquake Commission Research Report. Wellington. 4.1-4.19.

Holdgate, G. and Shaw, R. (2001). Cook Strait, New Zealand- a frontier basin. Eastern Australian Basins Symposium. Melbourne, Australia, Pet. Explor. of Aust. 
Jackson, J. A., White, N. J., Garfunkel, Z. and Anderson, H. (1988). "Relations between normal-fault geometry, tilting and vertical motions in extensional terrains: an example from the southern Gulf of Suez." Journal of Structural Geology 10(2): 155-170.

Lamarche, G., Barnes, P. M. and Bull, J. M. (2006). "Faulting and extension rate over the last 20,000 years in the offshore Whakatane Graben, New Zealand continental shelf." Tectonics 25(4): TC4005.

Lamb, S. H. (1988). "Tectonic rotations about vertical axes during the last $4 \mathrm{Ma}$ in part of the New Zealand plate-boundary zone." Journal of Structural Geology 10(8): 875-893.

Lamb, S. H. (2011). "Cenozoic tectonic evolution of the New Zealand plate boundary zone: A paleomagnetic perspective." Tectonophysics 509(135-164).

Langridge, R., Campbell, J., Hill, N., Pere, V., Pope, J., Pettinga, J., Estrada, B. and Berryman, K. (2003). "Paleoseismology and slip rate of the Conway Segment of the Hope Fault at Greenburn Stream, South Island, New Zealand." Annals of Geophysics(46 (5)).

Leonard, L. J., Hyndman, R. D. and Mazzotti, S. (2004). "Coseismic subsidence in the 1700 great Cascadia earthquake: Coastal estimates versus elastic dislocation models." Geological Society of America Bulletin 116(5-6): 655-670.

Little, T. A. (1995). "Brittle deformation adjacent to the Awatere strike-slip fault in New Zealand: Faulting patterns, scaling relationships, and displacement partitioning." Geological Society of America Bulletin 107(11): 1255-1271.

Little, T. A., Grapes, R. and Berger, G. W. (1998). "Late Quaternary strike slip on the eastern part of the Awatere fault, South Island, New Zealand." Geological Society of America Bulletin 110(2): 127148.

Little, T. A. and Jones, A. (1998). "Seven million years of strike-slip and related off-fault deformation, northeastern Marlborough fault system, South Island, New Zealand." Tectonics 17(2): 285-302.

Little, T. A. and Roberts, A. P. (1997). "Distribution and mechanism of Neogene to present-day vertical axis rotations, Pacific-Australian plate boundary zone, South Island, New Zealand." J. Geophys. Res. 102(B9): 20447-20468.

Little, T. A., Van Dissen, R., Schermer, E. and Carne, R. (2009). "Late Holocene surface ruptures on the southern Wairarapa fault, New Zealand: Link between earthquakes and the uplifting of beach ridges on a rocky coast." Lithosphere 1(1): 4-28.

Mason, D. P. M. and Little, T. A. (2006). "Refined slip distribution and moment magnitude of the 1848 Marlborough earthquake, Awatere Fault, New Zealand." New Zealand Journal of Geology and Geophysics 49(3): 375-382. 
Mason, D. P. M., Little, T. A. and Van Dissen, R. J. (2006). "Rates of active faulting during late Quaternary fluvial terrace formation at Saxton River, Awatere fault, New Zealand." Geological Society of America Bulletin 118(11-12): 1431-1446.

McCalpin, J. P. (1992). "Glacial geology of the upper Wairau Valley, Marlborough, New Zealand." New Zealand Journal of Geology and Geophysics 35(2): 211-222.

McCalpin, J. P. (2009). "Paleoseismology." International Geophysics Series 2nd Edition.

Murray, A. S. and Wintle, A. G. (2000). "Luminescence dating of quartz using an improved singlealiquot regenerative-dose protocol." Radiation Measurements 32(1): 57-73.

Oliver, M. A. and Webster, R. (1990). "Kriging: a method of interpolation for geographical information systems." International journal of geographical information systems 4(3): 313-332.

Pillans, B. (1991). "New Zealand Quaternary stratigraphy: An overview." Quaternary Science Reviews 10(5): 405-418.

Pochat, S., Castelltort, S., Choblet, G. and Van Den Driessche, J. (2009). "High-resolution record of tectonic and sedimentary processes in growth strata." Marine and Petroleum Geology 26(8): 13501364.

Pondard, N. and Barnes, P. M. (2010). "Structure and paleoearthquake records of active submarine faults, Cook Strait, New Zealand: Implications for fault interaction, stress loading, and seismic hazard." In submission.

Randall, K., Lamb, S. and Niocaill, C. M. (2011). "Large tectonic rotations in a wide zone of Neogene distributed dextral shear, northeastern South Island, New Zealand." Tectonophysics 509(3-4): 165180.

Reyners, M. (1998). "Plate coupling and the hazard of large subduction thrust earthquakes at the Hikurangi subduction zone, New Zealand." New Zealand Journal of Geology and Geophysics 41(4): $343-354$.

Roberts, A. P. (1995). "Tectonic rotation about the termination of a major strike-slip fault, Marlborough Fault System, New Zealand." Geophys. Res. Lett. 22(3): 187-190.

Robinson, R., Van Dissen, R. and Litchfield, N. (2011). "Using synthetic seismicity to evaluate seismic hazard in the Wellington region, New Zealand." Geophysical Journal International 187(1): 510-528.

Sibson, R. H. (1985). "Stopping of earthquake ruptures at dilational fault jogs." Nature 316(6025): 248-251. 
Sibson, R. H. (1994). "Crustal stress, faulting and fluid flow." Geological Society, London, Special Publications 78(1): 69-84.

Stein, R. S., Barka, A. A. and Dieterich, J. H. (1997). "Progressive failure on the North Anatolian fault since 1939 by earthquake stress triggering." Geophysical Journal International 128(3): 594-604.

Stirling, M., McVerry, G., Gerstenberger, M., Litchfield, N., Van Dissen, R., Berryman, K., Barnes, P., Wallace, L., Villamor, P., Langridge, R., Lamarche, G., Nodder, S., Reyners, M., Bradley, B., Rhoades, D., Smith, W., Nicol, A., Pettinga, J., Clark, K. and Jacobs, K. (2012). "National Seismic Hazard Model for New Zealand: 2010 Update." Bulletin of the Seismological Society of America 102(4): 1514-1542.

Townsend, D. B. (2001). Neogene evolution of the Pacific - Australia plate boundary zone in NE Marlborough, South Island, New Zealand, VUW Wellington. PhD thesis: 185.

Uruski, C. (1992). Sedimentary basins and structure of Cook Strait. Institute of Geological \& Nuclear Sciences Science Report. Lower Hutt, New Zealand. 92/3.

Uruski, C. (1999). Seismic picks PEP 38338 Cook Strait. IGNS Client Report. (Confidential to Tyers Petroleum Pty Ltd). 51990A.

Van Dissen, R. and Yeats, R. S. (1991). "Hope fault, Jordan thrust, and uplift of the Seaward Kaikoura Range, New Zealand." Geology 19(4): 393-396.

Vandergoes, M. J., Hogg, A. G., Lowe, D. J., Newnham, R. M., Denton, G. H., Barrel, D., Almond, P. C., Allan, A. and Wilson, C. J. N. (2011). Refining the Age of the Kawakawa/Oranui Tephra in New Zealand. XVIII INQUA-Congress. Bern, Switzerland. Abstract.

Wakabayashi, J. (1999). "Distribution of displacement on and evolution of a young transform fault system: The northern San Andreas fault system, California." Tectonics 18(6): 1245-1274.

Wallace, L. M., Barnes, P., Beavan, J., Van Dissen, R., Litchfield, N., Mountjoy, J., Langridge, R., Lamarche, G. and Pondard, N. (2012). "The kinematics of a transition from subduction to strike-slip: An example from the central New Zealand plate boundary." J. Geophys. Res. 117(B2): B02405.

Wallace, L. M. and Beavan, J. (2004). "Subduction zone coupling and tectonic block rotations in the North Island, New Zealand." Journal of Geophysical Research 109(B12406).

Wells, D. L. and Coppersmith, K. J. (1994). "New empirical relationships among magnitude, rupture length, rupture width, rupture area, and surface displacement." Bulletin of the Seismological Society of America 84(4): 974-1002,A1001-A1004,B1001-B1011,C1001-C1049. 
Wesnousky, S. G. (1988). "Seismological and structural evolution of strike-slip faults." Nature 335(6188): 340-343.

Zachariasen, J., Berryman, K., Langridge, R., Prentice, C., Rymer, M., Stirling, M. and Villamor, P. (2006). "Timing of late Holocene surface rupture of the Wairau Fault, Marlborough, New Zealand." New Zealand Journal of Geology and Geophysics 49(1): 159-174.

Zachariasen, J., Sieh, K., Taylor, F. W. and Hantoro, W. S. (2000). "Modern Vertical Deformation above the Sumatran Subduction Zone: Paleogeodetic Insights from Coral Microatolls." Bulletin of the Seismological Society of America 90(4): 897-913. 


\section{Appendix A: Optically Stimulated Luminescence Dating technique and data}

Optically Stimulated Luminescence (OSL) samples were collected from silt or sand in a stratigraphic section by digging into a fresh surface at least $30 \mathrm{~cm}$ into the cutting and hammering in a $\sim 10 \mathrm{~cm}$ in diameter, $\sim 30 \mathrm{~cm}$ long metal core into the exposed surface. The core is then pulled out of the cutting and covered in foil, leaving the middle of the core unexposed to light. We wrap in tin foil so that we can assume that grains within the sample have not been exposed to light since deposition. One of the samples (AF2) was a block of cemented sand $\sim 30 \mathrm{~cm}$ in diameter pulled from the Boundary stratigraphic section in Chapter 2.

The samples were then analysed within a dark room at the VUW Luminescence Laboratory. A fine grain $(4-11 \mu \mathrm{m})$ technique was used to prepare the samples. The silt and sand samples had their outer surfaces removed so unexposed 'fresh' sample can be analysed. This sample material was treated in $10 \% \mathrm{HCl}$ overnight to remove all carbonate. Then the sample was treated with $10 \% \mathrm{H}_{2} \mathrm{O}_{2}$ over night to remove all organic matter. $200 \mathrm{ml}$ of CBD solution (71 g sodium citrate, $8.5 \mathrm{~g}$ sodium bicarbonate, and $2 \mathrm{~g}$ sodium dithionate per litre of distilled water) was then added to the sample for 12 hours to remove iron oxide coatings. After every chemical treatment the sample was washed with distilled water several times. After the chemical treatment, calgon solution $(1 \mathrm{~g}$ sodium hexametaphosphate per litre of distilled water) was added to the sample to make a thick slurry, and was mechanically agitated for an hour. The sample was then placed into a $1 \mathrm{~L}$ measuring cylinder and filled with water to separate out the 4-11 $\mu \mathrm{m}$ grains according to Stokes' Law. The grains were then rinsed with ethanol and acetone and a suspension of these grains were deposited onto 70 aluminium disks $9.8 \mathrm{~mm}$ in diameter. They were then dried in an oven, milled, weighed, and sealed in air tight perspex containers for four weeks to minimize the loss of the short lived noble gas ${ }^{222} \mathrm{Rn}$ and allows ${ }^{226} \mathrm{Ra}$ to reach equilibrium with its daughters ${ }^{214} \mathrm{~Pb}$ and ${ }^{214} \mathrm{Bi}$. 
The Luminescence age was measured by running the samples through gamma spectrometer analysis in order to equivalent dose (De) and the dose rate.

The De for each sample was obtained by the Multiple Aliquot Dose Method (MAAD). Firstly, the test dose was measured from an initial test measurement. Then disks for each sample were normalised to account for luminescence variation between disks before beta $(\beta)$ irradiation. $0.1 \mathrm{~s}$ infrared measurements were taken before six groups of five disks were $\beta$ irradiated up to five times the test dose. The $\beta$ irradiation was done on the Riso TL-DA- $15{ }^{90} \mathrm{Sr} / \mathrm{Y} \beta$ irradiator, calibrated against a ${ }^{60}$ Co gamma source, SFU, Vancouver, Canada. Three groups of three disks were $\alpha$ irradiated up to three times the test dose. The $\alpha$ irradiation was done on a ${ }^{241} \mathrm{Am}$ irradiator, supplied and calibrated by ELSEC Littlemore, UK. The $39 \beta$ and $\alpha$ irradiated disks and nine non-irradiated disks were stored for four days to relax the crystal lattice after irradiation. After storage the 48 disks were preheated for 5 minutes at $230^{\circ} \mathrm{C}$, then they were stimulated with a $30 \mathrm{~mW} / \mathrm{cm}^{2}, 880 \mathrm{~nm}$ infrared beam for $100 \mathrm{~s}$ at room temperature in the Riso TL-DA-15 reader. Blue Luminescence of about $410 \mathrm{~nm}$ emission from feldspar was then detected by an EMI 9235QA multiplier fixed behind two filters (Schott BG-39 and Kopp 5-58). A Luminescence growth curve was constructed by using the initial 10 $\mathrm{s}$ of shine down and subtracting the average of the last $20 \mathrm{~s}$ (background). Extrapolation of the growth curve to the dose axis obtained the equivalent dose. A similar plot for the $\alpha$ irradiated disks obtained an estimation of $\alpha$ efficiency, the a-value.

The dose rate was obtained in two parts: from the burial environment and from cosmic rays. The dose rate was determined by the sample's burial environment by radionuclide contents of ${ }^{238} \mathrm{U}$, ${ }^{232} \mathrm{Th}$ and ${ }^{40} \mathrm{~K}$, a-value and water content. The contents of $\mathrm{U}$, Th and $\mathrm{K}$ were determined by gamma spectroscopy, where gamma rays produced from the sample are counted for a minimum 24 hours by a high resolution and broad energy gamma spectrometer (Table A1). The dose rate was calculated based on the activity concentration of the nuclides ${ }^{40} \mathrm{~K},{ }^{208} \mathrm{TI},{ }^{212} \mathrm{~Pb},{ }^{228} \mathrm{Ac},{ }^{214} \mathrm{Bi}^{214} \mathrm{~Pb}$, and ${ }^{226} \mathrm{Ra}$, using dose rate conversion factors from Adamec and Aitken[1998]. The dose rate was determined from 
cosmic rays by the sample's depth, longitude and latitude using formula and factors from Prescott and Hutton [1994] (Table A2).

\begin{tabular}{|c|c|c|c|c|c|c|}
\hline Sample & $\begin{array}{c}\text { Water } \\
\text { content } \\
(\%)\end{array}$ & $\begin{array}{c}\mathrm{U}(\mathrm{ppm}) \\
\text { from }{ }^{234} \mathrm{Th}\end{array}$ & $\begin{array}{c}\mathrm{U}(\mathrm{ppm}) \text { from } \\
{ }^{226} \mathrm{Ra},{ }^{214} \mathrm{~Pb}, \\
{ }^{214} \mathrm{Bi}\end{array}$ & $\begin{array}{c}\mathrm{U}(\mathrm{ppm}) \\
\text { from }{ }^{210} \mathrm{~Pb}\end{array}$ & $\begin{array}{c}\mathrm{Th}(\mathrm{ppm}) \text { from } \\
{ }^{208} \mathrm{Ti},{ }^{212} \mathrm{~Pb},{ }^{228} \mathrm{Ac}\end{array}$ & $\mathrm{K}(\%)$ \\
\hline AF2 & 8.25 & $2.79 \pm 0.28$ & $2.57 \pm 0.17$ & $2.39 \pm 0.23$ & $8.44 \pm 0.12$ & $1.93 \pm 0.04$ \\
\hline VF1 & 15.3 & $2.41 \pm 0.18$ & $2.60 \pm 0.12$ & $2.57 \pm 0.16$ & $8.70 \pm 0.10$ & $1.50 \pm 0.03$ \\
\hline VF2 & 16.18 & $3.21 \pm 0.36$ & $3.08 \pm 0.22$ & $2.53 \pm 0.28$ & $13.20 \pm 0.19$ & $1.57 \pm 0.04$ \\
\hline
\end{tabular}

Table A1) Water Contents, Radionuclide Contents

\begin{tabular}{|c|c|c|}
\hline Sample & $\begin{array}{c}\text { Depth below } \\
\text { surface }(\mathrm{m})\end{array}$ & $\begin{array}{c}\text { Cosmic Dose } \\
\text { Rate }(\mathrm{Gy} / \mathrm{ka})\end{array}$ \\
\hline AF2 & 2.75 & $0.1445 \pm 0.0072$ \\
\hline VF1 & 1.15 & $0.1796 \pm 0.0090$ \\
\hline VF2 & 2 & $0.1600 \pm 0.0080$ \\
\hline
\end{tabular}

Table A2) Cosmic Dose Rates

\begin{tabular}{|c|c|c|c|c|}
\hline Sample & a-value & De (Gy) & $\begin{array}{c}\text { Dose rate } \\
(\mathrm{Gy} / \mathrm{ka})\end{array}$ & $\begin{array}{c}\text { Luminescence } \\
\text { age (ka) }\end{array}$ \\
\hline AF2 & $0.059 \pm 0.003$ & $131.66 \pm 2.44$ & $3.72 \pm 0.08$ & $\mathbf{3 5 . 4} \pm \mathbf{1 . 0}$ \\
\hline VF1 & $0.044 \pm 0.002$ & $117.63 \pm 1.58$ & $3.01 \pm 0.05$ & $\mathbf{3 9 . 1} \pm \mathbf{0 . 9}$ \\
\hline VF2 & $0.04 \pm 0.02$ (est.) & $410.27 \pm 23.25$ & $3.50 \pm 0.26$ & $\mathbf{1 1 7 . 2} \pm \mathbf{1 0 . 9}$ \\
\hline
\end{tabular}

Table A3) a-values, Dose Rates, Equivalent Doses and Luminescence Ages 


\section{Appendix B: Real-time Kinematic GPS survey techniques and data}

The topographic maps used in this study are constructed by using Real-time Kinematic (RTK) GPS to survey landforms displaced by faults. The survey is undertaken by first setting up the stationary base receiver on a tripod within line of sight of the whole survey area. Once the base receiver had been positioned by satellite, the rover receiver was connected to the base receiver wirelessly by radio (Bluetooth). A Real Time Phase Differential is used to compute the $3 \mathrm{D}$ vector between the base and rover receivers, hence the relative position of the rover receiver to the base receiver. The rover receiver was mounted onto a backpack and the height of the receiver from the ground was measured and cancelled for using a tape measure. The positions of the survey points within the survey were measured at 0.5-2 $\mathrm{m}$ intervals depending on the survey extent. To measure these points I walked in lines parallel to the fault at 0.5-5 $\mathrm{m}$ intervals and also gathered extra points of interest on the displaced landforms (e.g. Bottom and top of riser, fault etc.).

The survey data is input into a spread sheet which includes the easting, northing and elevation of each survey point. The data is then input into a Geographic Information system $\left(\operatorname{ArcGIS}{ }^{\odot}\right.$ ) as a point file. The elevation point file is then converted to a Digital Elevation Model (DEM) using a kriging interpolation [Oliver, 1990]. The DEM is an elevation field in which the elevation is interpolated for positions between survey points. Cell sizes of $0.5-10 \mathrm{~m}$ were used for the kriging interpolation, in accordance with the spacing between the survey points. Each cell has an elevation dependant on the elevation, distance away and the number of survey points nearby. A contour map of the DEM was then constructed for interpretation of the geomorphic landforms. 
The following diagrams show the original un-interpreted topographic maps from all of the RTK topographic maps of displaced landforms in Chapters 1 and 2. Interpreted RTK GPS topographic maps that were not displayed within chapters 1 and 2 are also displayed. Each diagram is labelled by site number and Chapter they are featured in, the measurements can be viewed in Table 1 and are located in Fig. 2 in both Chapters 1 and 2. These diagrams show the dextral or the vertical displacement of late Quaternary features. 

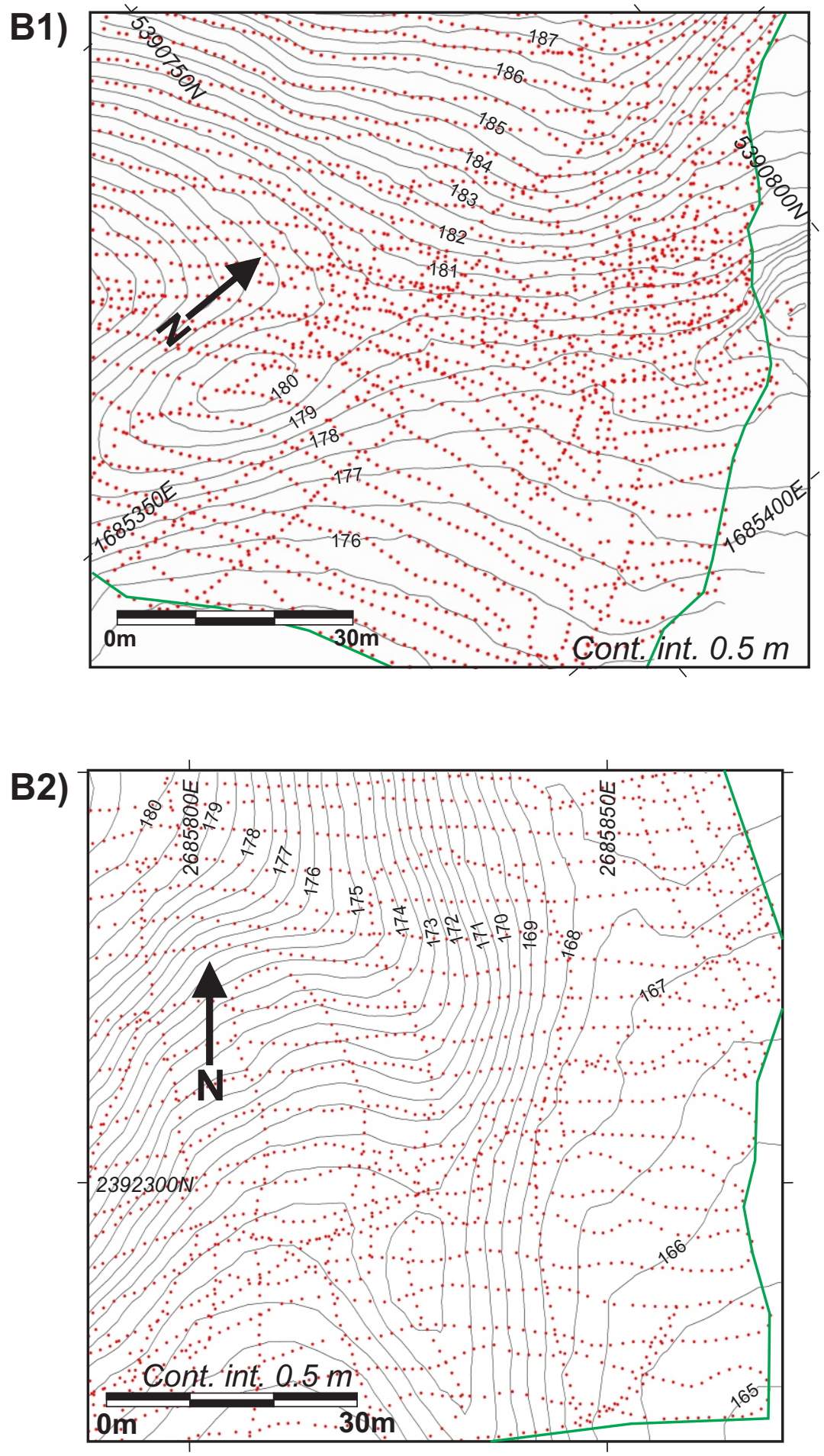

Figure B1) Contour map from Fig. $4 a$ in chapter 1. Cell size $=2 \mathrm{~m}$. B2) Contour map from Fig. $4 b$ in chapter 1.Cell size $=4 \mathrm{~m}$. These maps show the RTK GPS survey points (red dots), and the surveyextent (green line). 

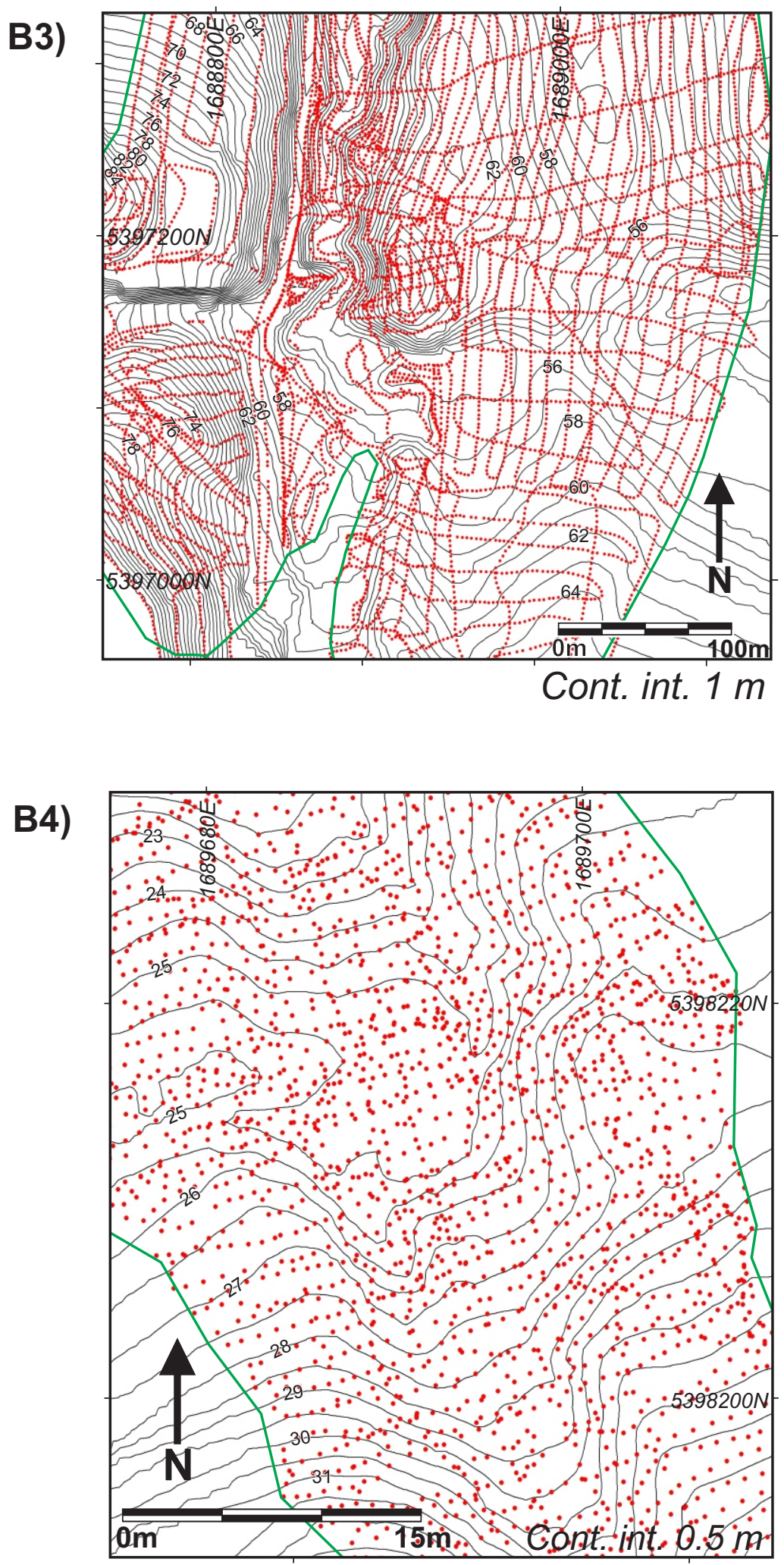

Figure B3) Contour map from Fig. $5 a$ in chapter 1. Cell size $=10 \mathrm{~m}$. B4) Contour map from Fig. $5 b$ in chapter 1 . Cell size $=0.5 \mathrm{~m}$. These maps show the RTK GPS survey points (red dots), and the survey extent (green line). 


\section{B5)}

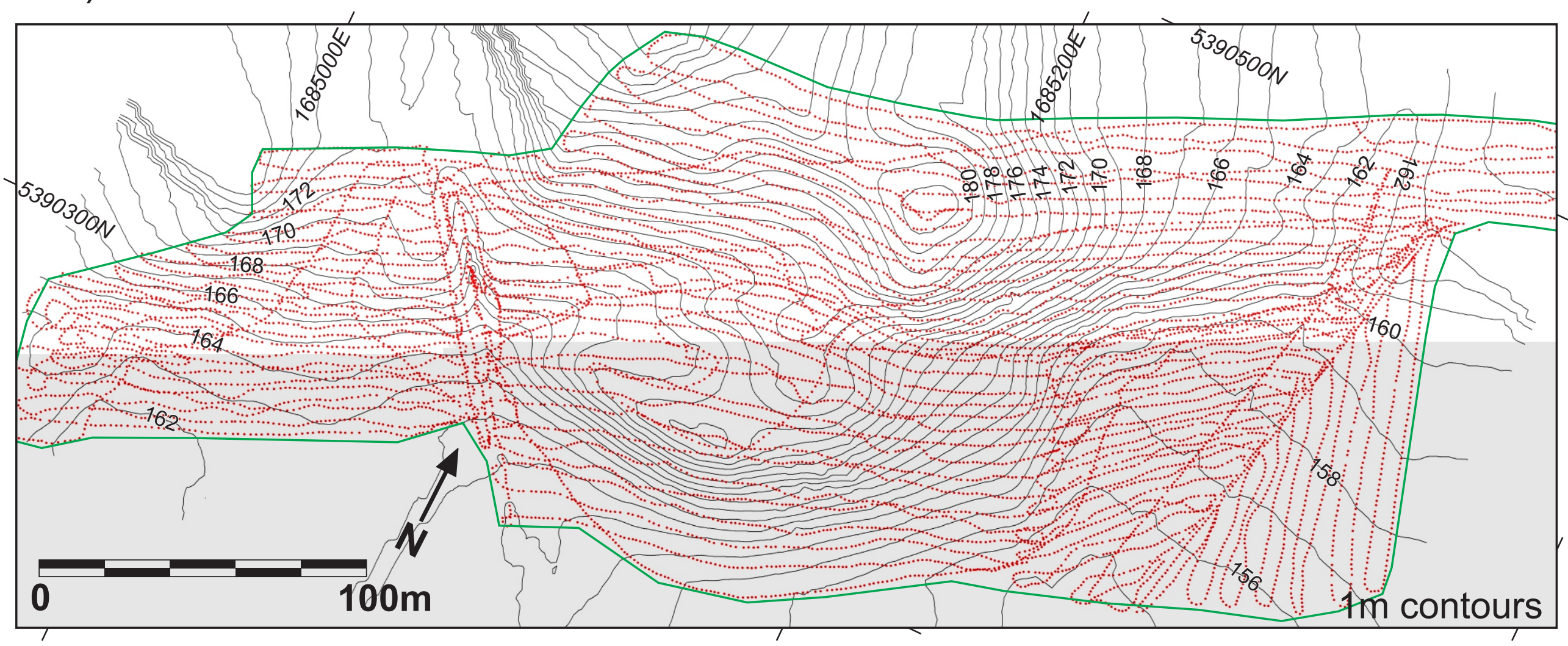

Figure B5) Contour map from Fig. 4a in chapter 2. Cell size $=5 \mathrm{~m}$. This map shows the RTK GPS survey points (red dots), and the survey extent (green line). 


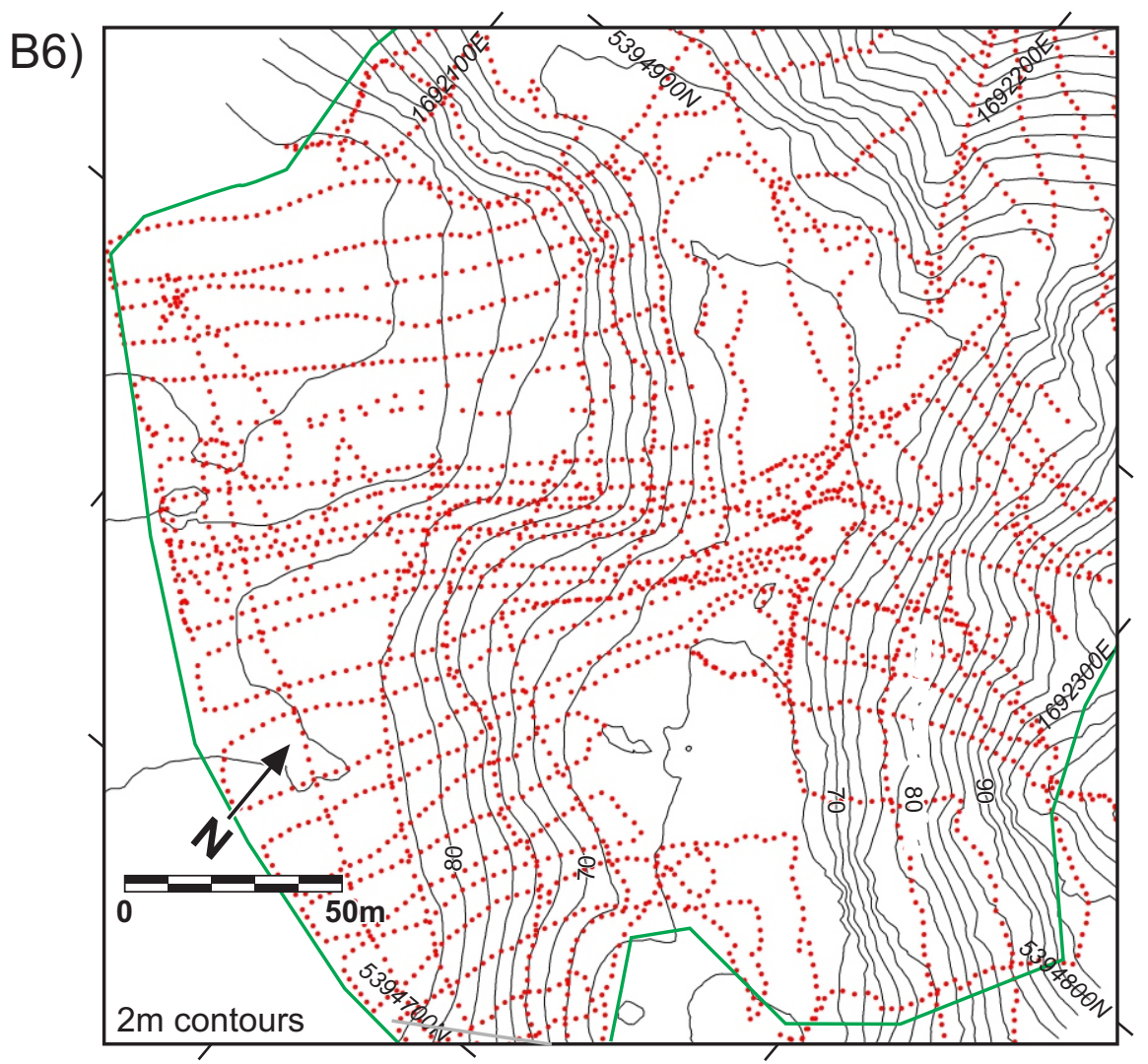

B7)

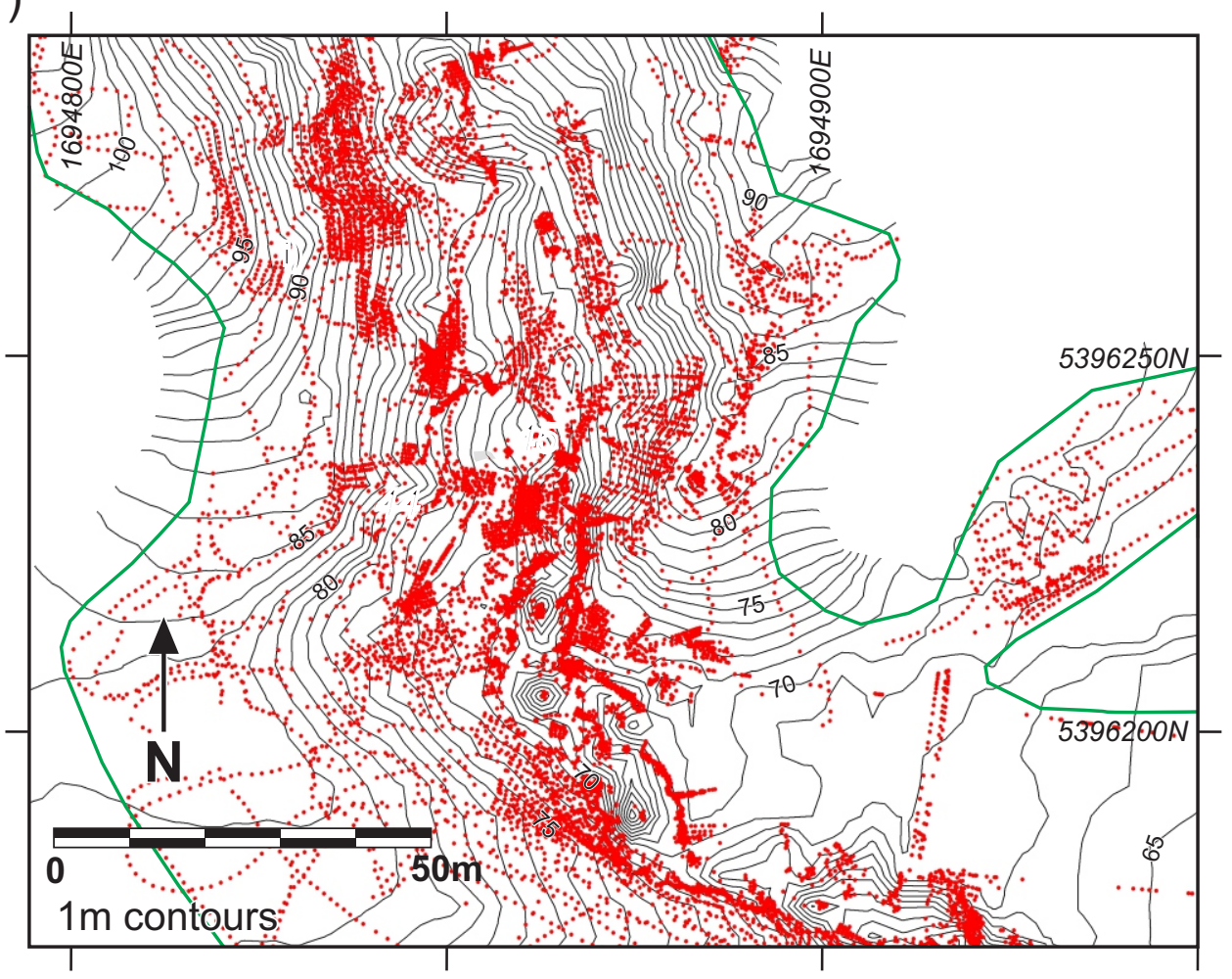

Figure B6) Contour map from Fig. $5 a$ in chapter 2. Cell size $=5 \mathrm{~m}$. B7) Contour map from Fig. $5 \mathrm{~b}$ in chapter 2 . Cell size $=4 \mathrm{~m}$. These maps show the RTK GPS survey points (red dots), and the survey extent (green line). 
Site 3, Chapter 1
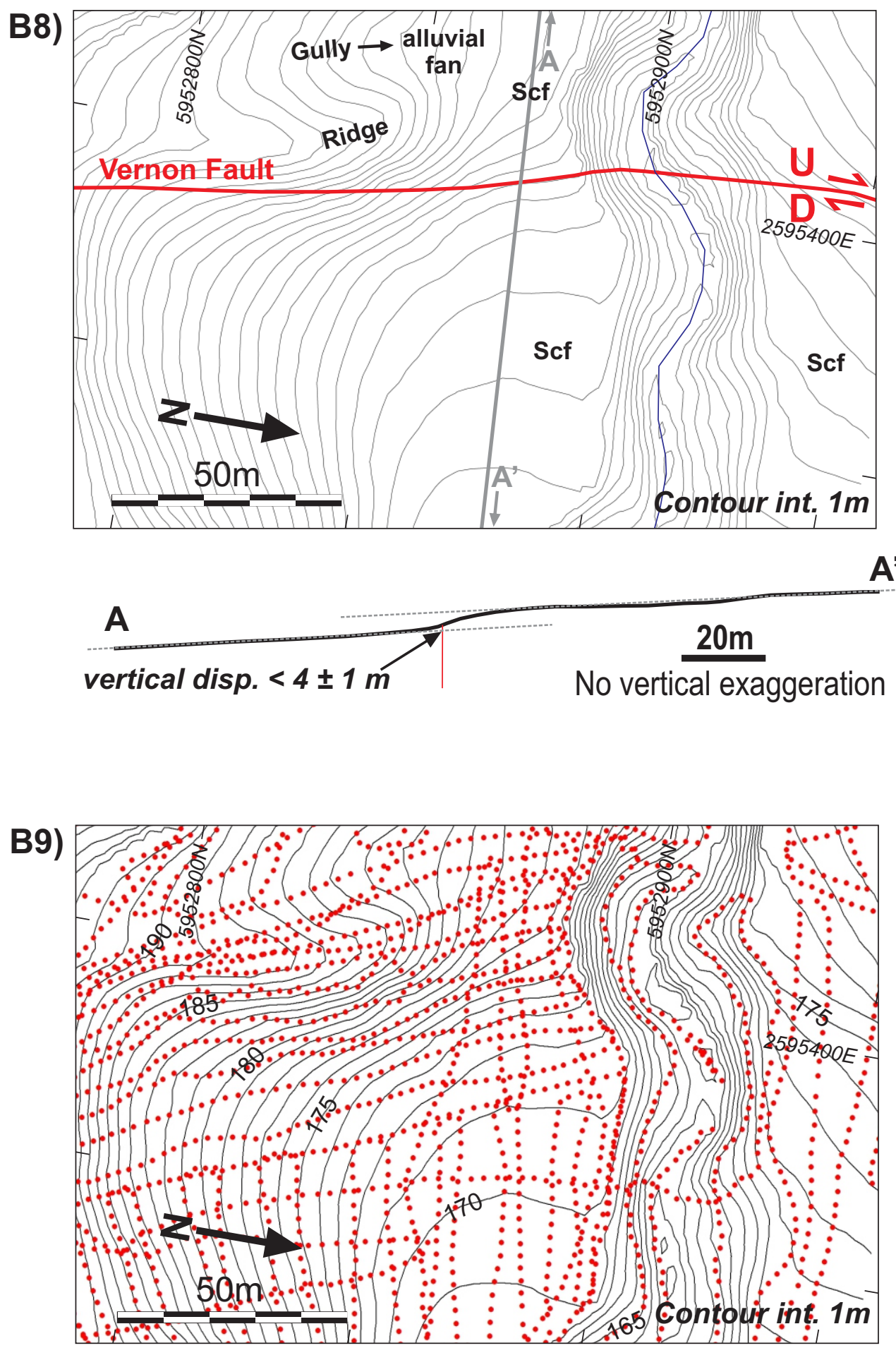

Figure B8) Contour map and cross-fault cross section of the vertical displacement of the Stafford Creek fan surface by the Dumgree Splay (site 3, chapter 1). The measurement is a maximum because an alluvial fan overlies the SCf on the up-thrown side of the fault. B9) Contour map of the map above showing the RTK GPS survey points (red dots), and the survey extent (green line). Cell size $=5 \mathrm{~m}$. 
Site 8, Chapter 2
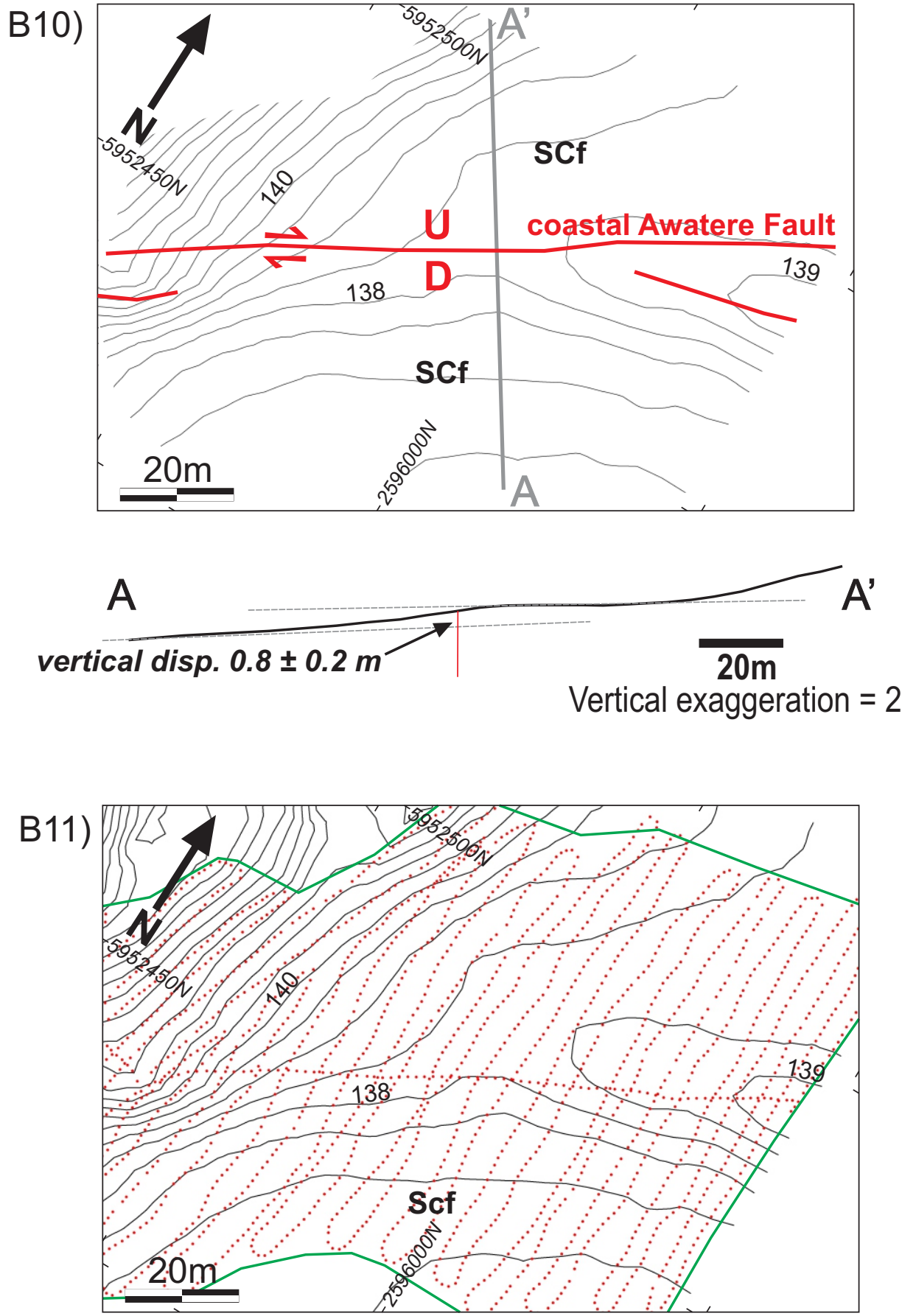

Figure B10) Contour map and cross-fault cross section of the vertical displacement of the Stafford Creek fan surface by the coastal Awatere Fault (site 3, chapter 2). B11) Contour map of the map above showing the RTK GPS survey points (red dots), and the survey extent (green line). Cell size $=8 \mathrm{~m}$. 
Site 32, Chapter 2
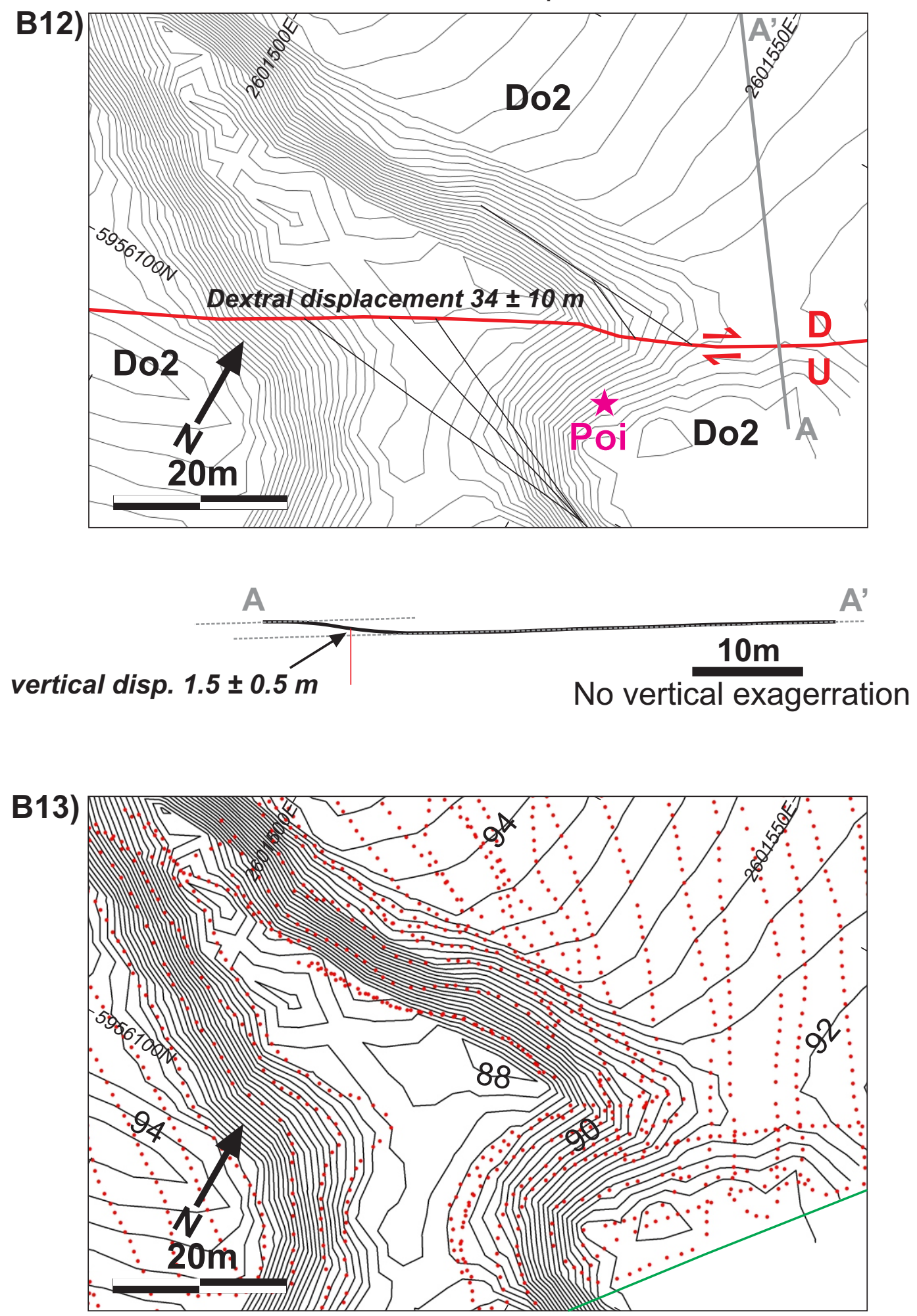

Figure B12 Contour map and cross-fault cross section showing the dextral and vertical displacement of the Downs 2 terrace by the coastal Awatere Fault (site 32, chapter 2). A riser incised into the Downs 2 terrace is displaced. The locality of the Poi section (Fig. 3d, chapter 2) is also shown. B13) Contour map of the map above showing the RTK GPS survey points (red dots), and the survey extent (green line). Cell size $=5 \mathrm{~m}$. 
Site 33, Chapter 2

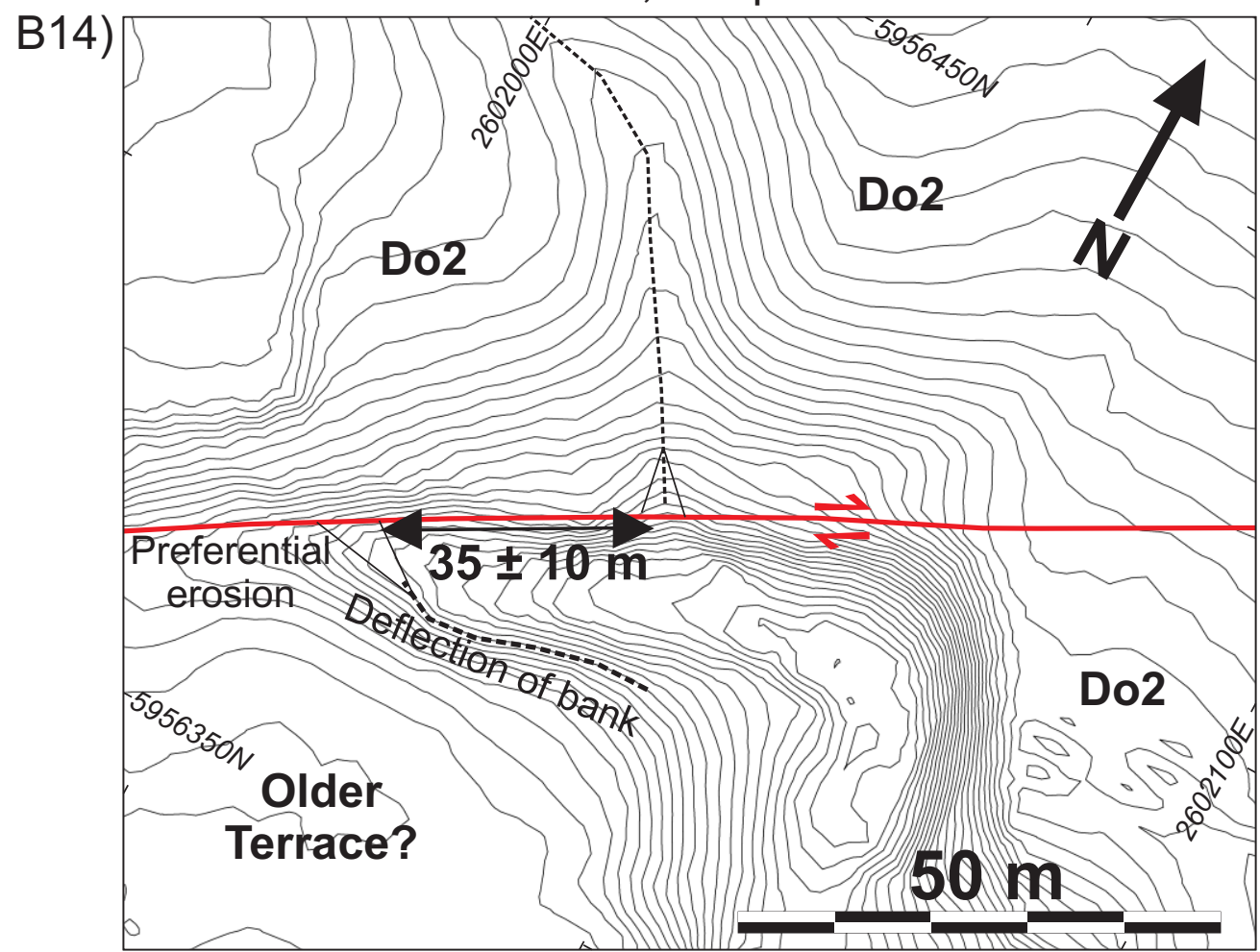

B15)

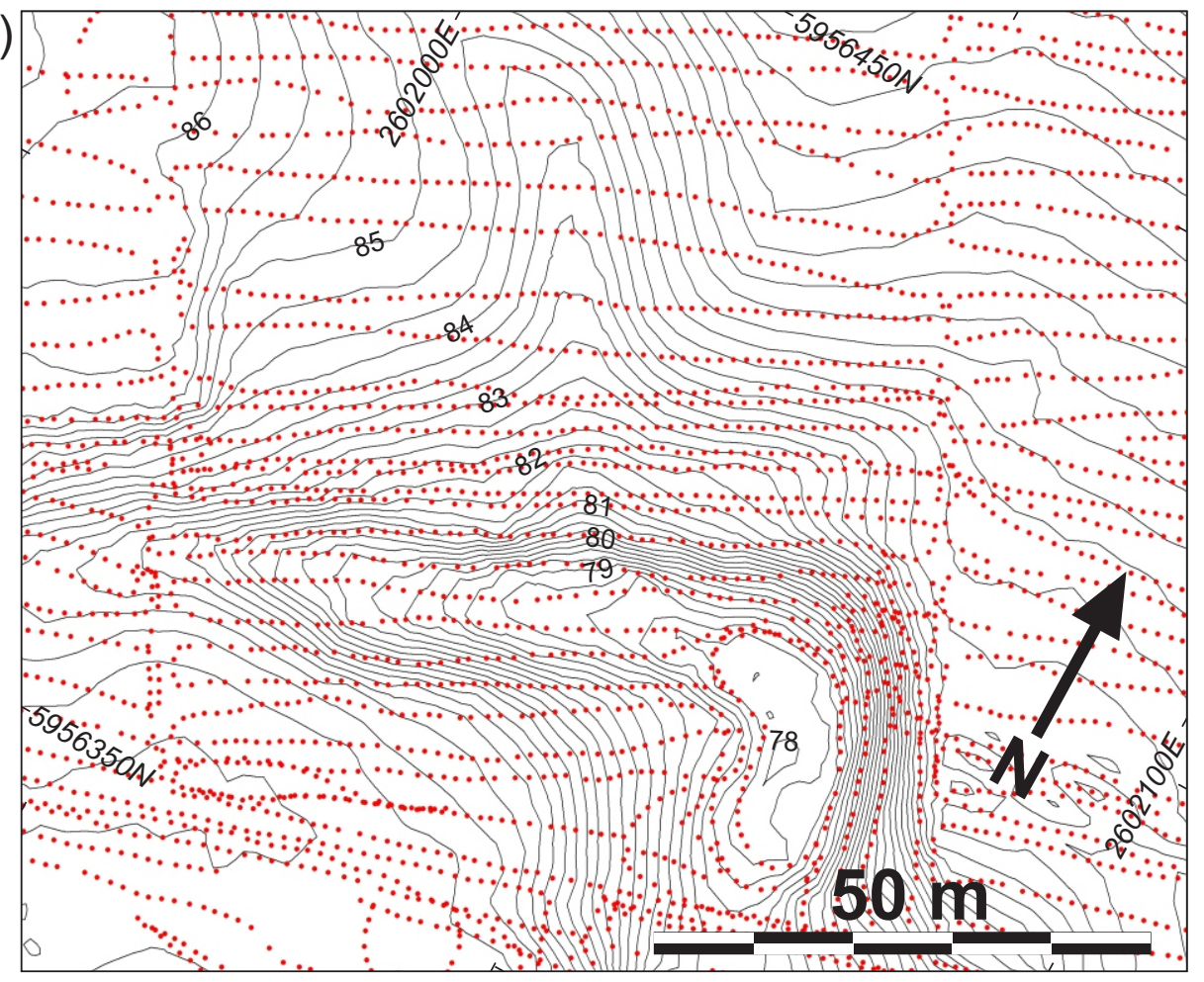

Figure B14) Contour map the dextral displacement of a gully incised into the Downs 2 terrace by the coastal Awatere Fault (site 33, chapter 2). The stream is clearly located north of the fault and is mapped on the south side of the fault by the deflection of the southern bank northwards towards the fault and deepening of the fault-parallel gully. B15) Contour map of the map above showing the RTK GPS survey points (red dots), and the survey extent (green line). Cell size $=5 \mathrm{~m}$. 


\section{Appendix C: Trench unit descriptions}

The following table shows the trench unit descriptions from Chapter 1. Table is from Clark et al., [2011b]. 


\begin{tabular}{ccc}
\hline Unit \# & $\begin{array}{c}\text { Short } \\
\text { description }\end{array}$ & Full description \\
\hline
\end{tabular}

0

Fill

$1 \mathrm{~A}$

1

2

3

4

5

6

7

8

9

10

11

$11 x$

$12+13$

14

Peat

Gravel

Crudely stratified, basal $10-30 \mathrm{~cm}$ is mixed peat, silt, greywacke cobbles, dark brown-black organic-rich silt. Above it is $10-20 \mathrm{~cm}$ thick chaotic silt and cobbles, silt-matrix-supported, becomes richer in silt toward ground surface.

Topsoil Light grey-brown loose silt, scattered rounded pebble $<2 \mathrm{~cm}$ diameter.

Paleosol Silty brown-grey paleosol

Dark grey-brown organic clay, mottled, scattered with rounded clasts to $3 \mathrm{~cm}$ diameter, and charcoal fragments

Massive medium brown organic clay, moderately stiff, very rare scattered pebbles, subrounded up to $2 \mathrm{~cm}$ diameter

Dark brown-black, clayey organic silt with soil structure (nutty, crumbly). Very rare clasts, angular to $6 \mathrm{~cm}$ diameter.

Equivalent to 6 but with more weathered clasts

Grey poorly sorted gravel, rounded to subrounded, closely packed, clasts $2-5 \mathrm{~cm}$ diameter, gritty silty matrix

Gravel

Clayey silt

Silt

Clayey gravel

Silt

Silt / loess

Gravel

Gravel

Gravel

Gravel

Silt

Silt

Massive silt

Silt

Silt

Silty gravel

Silty gravel

Silt

Fine gravel with cobbles

Sandy silt

Gravel
Medium grey-orange mottled silty clay, massive and stiff

Stiff, medium-grey silt, slightly clayey, some orange Fe-staining, sparse subangular pebbles within silt. Upper $30-40 \mathrm{~cm}$ is rich in $\mathrm{Mn}$ nodules (weathering zone).

Medium-grey silty clay with frequent pebbles. Subrounded to rounded up to $8 \mathrm{~cm}$ diameter.

Light yellow-grey compact silt, frequent rounded to subangular clasts up to $8 \mathrm{~cm}$ diameter, average size $2 \mathrm{~cm}$.

Loess (?). Massive light orange-grey silt, vertically veined throughout, veins becoming more densely spaced toward fault zone, occasional subangular pebbles $(<1 \mathrm{~cm}$ diameter).

Very sheared compact, poorly sorted gravel. Mostly medium-grey with $\mathrm{Mn}$ and Fe staining. Clayey-silty matrix, average clast size $3 \mathrm{~cm}(\mathrm{mx} 8 \mathrm{~cm})$, subangular to angular, possibly equivalent to unit 14 .

Medium orange-grey, very compact, dominantly subangular gravel. Stiff silty matrix, abundant iron-staining and manganese. Strongly weathered. Poorly sorted, clasts $1-12 \mathrm{~cm}$. Contained a fine sandy marker later $4 \mathrm{~cm}$ thick.

Very poorly sorted silty gravel, rounded to subangular clasts, 1 to $6 \mathrm{~cm}$ diameter. Contains occasional silty sand lenses, some crude horizontal bedding. Locally iron-stained.

(Source of unit 15) Moderately loose grey-brown gravel with fine sandy matrix, abundant tightly packed medium-fine pebbles, contains (especially near base) some subangular clasts up to $12 \mathrm{~cm}$ diameter.

Medium brownish grey silt, iron-stained, pebbles to $3 \mathrm{~cm}$ diameter.

Medium grey silt, orange mottled, occasional subrounded pebbles up to $1 \mathrm{~cm}$ diameter.

Massive light yellow-grey to light orange-grey silt, very stiff.

Very stiff light yellow-grey silt with many subangular to subrounded clasts $2-5 \mathrm{~cm}$ diameter. Some Mn staining.

Medium orange-grey silt, some fine sand and scattered subangular clasts up to $2 \mathrm{~cm}$ diameter.

Very compact, light yellow-grey silt with frequent pebbles. Subangular to subrounded 2-5 $\mathrm{cm}$ diameter, pebbles decrease towards south.

Medium brown-grey silty gravel, $\mathrm{Mn}$ weathering, very compact angular to rounded clasts 1$3 \mathrm{~cm}$ diameter.

Pale yellow stiff silt with scattered pebbles $<2 \mathrm{~cm}$ diameter.

Medium grey silty fine gravel, rounded to subrounded to angular clasts, mean size $<4 \mathrm{~cm}$, max $10 \mathrm{~cm}$. Well-sorted pebble layer at base ( $1 \mathrm{~cm}$ size).

Dark grey massive medium sandy silt, occasional rounded pebbles up to $3 \mathrm{~cm}$ diameter.

Dark brown gravelly sily, clasts up to $6 \mathrm{~cm}$ diameter, rounded, matrix-supported, fresh to well-weathered clasts 
27 Sand Medium grey silty fine sand and medium sand, soft

28 Coarse gravel Dark grey cobble gravel, silty grey-brown matrix, slightly organic, cobbles of mean size 10

$\mathrm{cm}$.

29 Sheared silt Sheared version of unit 11 silt. More weathered and contained scattered angular pebbles 1 $\mathrm{cm}$ diameter.

\section{Units only on eastern wall}

\begin{tabular}{|c|c|c|}
\hline $10 \mathrm{~A}$ & Fine gravel & Fine gravel, like unit 10 but more gravel \\
\hline $11 \mathrm{~A}$ & Silt & Silimar to 11 of west wall but absence of veining and Fe-staining. \\
\hline $2 \mathrm{~A}$ & Organic silt & Same as unit 2 but more organic material \\
\hline 30 & Fine gravel & Very compact silty pebbly gravel, pale yellow grey, mean clast size , $1 \mathrm{~cm}$ diameter. \\
\hline 31 & Fine gravel & $\begin{array}{l}\text { Very stiff, tighly packed silty pebbly gravel, Fe-stained, moderate Mn development, } \\
\text { subrounded to angular clasts, mean diameter } 2 \mathrm{~cm}\end{array}$ \\
\hline 32 & Gravelly silt & Pale brown very gritty silt, scattered rounded to angular clasts, moderate Mn development. \\
\hline 33 & Blocky silt & $\begin{array}{l}\text { Pale grey-brown very stiff gritty silt, minor } \mathrm{Mn} \text { nodules, scattered subrounded clasts to } 3 \mathrm{~cm} \\
\text { diameter. }\end{array}$ \\
\hline 34 & $\begin{array}{l}\text { Pebbly gravel } \\
\text { gravel }\end{array}$ & $\begin{array}{l}\text { Pale brown pebbly gravel with loose silty crumbly matrix. Clasts subrounded to subangular, } \\
1-5 \mathrm{~cm} \text { diameter, similar texture to unit } 15 \text { but no } \mathrm{Mn} \text { development. }\end{array}$ \\
\hline 34 & Gravelly silt & $\begin{array}{l}\text { Same as } 11 \text { but more clasts, subangular to subrounded, average } 1 \mathrm{~cm} \text {, mean } 4 \mathrm{~cm} \text { diameter, } \\
\text { very sheared. }\end{array}$ \\
\hline 35 & Silty gravel & $\begin{array}{l}\text { Light brown grey very compact silty gravel, moderate } \mathrm{Mn} \text { development, clasts rounded to } \\
\text { subangular, clast size and cobbles increase near base up to } 8 \mathrm{~cm} \text { diameter, } 4 \mathrm{~cm} \text { at top. }\end{array}$ \\
\hline 36 & Silt & Massive silt, very sheared, contains many angular pebbles. \\
\hline 37 & Gravel & $\begin{array}{l}\text { (fault slice) Medium grey very stiff clayey gravel, strong Mn development, angular to } \\
\text { subrounded, } 1 \mathrm{~cm} \text { ave clasts size, } 3 \mathrm{~cm} \text { max. }\end{array}$ \\
\hline 38 & Silt with gravel & $\begin{array}{l}\text { Medium grey silt, slightly Fe-stained, scattered subangular clasts, many pebbles }<1 \mathrm{~cm} \text {, up } \\
\text { to } 6 \mathrm{~cm} \text { diameter near base. }\end{array}$ \\
\hline 39 & Fine grey sand & $\begin{array}{l}\text { Medium grey silty fine sand, masiive, coarsens upward, rare subangular clasts up to } 3 \mathrm{~cm} \\
\text { diameter. }\end{array}$ \\
\hline 40 & Gravel & Medium grey clayey silty cobbley gravel. \\
\hline
\end{tabular}




\section{Appendix D: Extra offshore paleoseismic working}

D1- Figure from Barnes and Pondard [2010] outlining the conceptual model on which I measured paleoseismic records offshore on seismic lines.

Caption from Barnes and Pondard [2010]: Conceptual model for the development of fault growth strata and the preservation potential for paleoearthquake records on the continental shelf as a function of constant sedimentation rate and vertical displacement rate, during four earthquake cycles. (left) Shallow profiles (meters to tens of meters) across the tip of an active fault. (right). Plots of vertical displacement accumulation with time, showing the timing of each earthquake, with earthquake 1 (EQ1) being the youngest (i.e., the last event) and earthquake 4 (EQ4) being the oldest. Note that the inclined parts of the displacement-time plots corresponding to postseismic growth sequences need not necessarily be linear and may be characterized by flattening tails associated with the later stages of growth sequence development. The horizon labeled PGS2/1 on each profile is the last postglacial marine transgressive surface. (a) A site where the average long-term sedimentation rate exceeds the long-term vertical displacement rate on the fault has excellent potential for preservation of paleoearthquake records, through differentiation of the postseismic growth sequences from the intervening uniformly thick sequences. (b) A site where the vertical displacement rate exceeds the sedimentation rate will be associated with a permanent fault scarp and stacked postseismic growth sequences. Earthquake preservation in the displacement-time plot will be poor to absent (although there may be other sequence/stratal characteristics present that enable recognition of the earthquakes). (c) A site where fault growth occurs with no synkinematic growth sedimentation has no potential for preservation of paleoearthquakes. See text for full explanation. Note that these generic concepts may apply equally to marine and terrestrial settings. 
D2-8- Offshore paleoseismic working on each of the TAN0510 boomer seismic lines not displayed in Chapter 1. Each page shows three diagrams based on one seismic line. These pages show an uninterpreted, interpreted boomer seismic line and a vertical displacement-age plot of each line. The seismic lines have a vertical exaggeration of 32. On the interpreted lines, translucent yellow areas lines show post-seismic growth sequences. On the left of the growth sequences, the respective earthquake identified and approximate age displayed. The coloured reflectors provide the age constraint in the profiles, with their approximate ages displayed. In the vertical displacement-age plots fault growth sequences are the 'ramps' in the data. 


\section{Fault vertical displacement rate < Sedimentation rate}

Periodic fault scarp, separated growth sequences,

excellent paleo-earthquake preservation
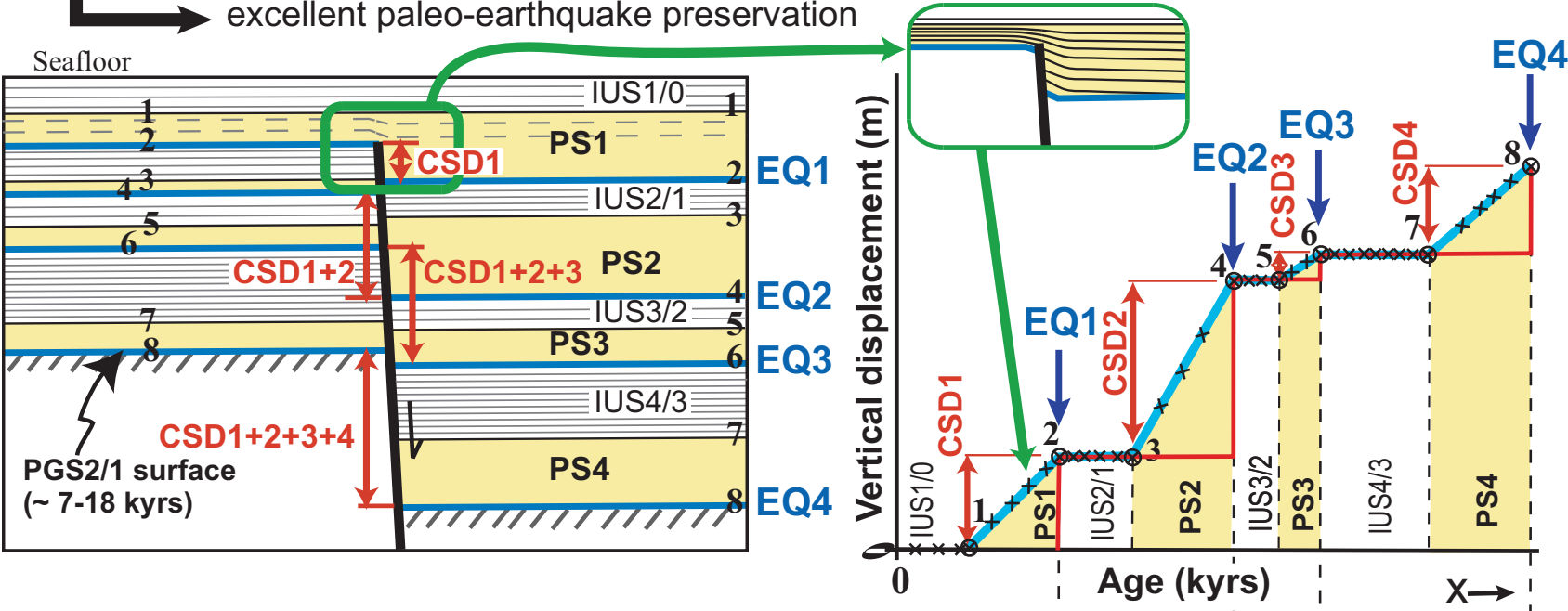

\section{Fault vertical displacement rate $>$ Sedimentation rate}

Permanent fault scarp, No IUS developed, poor to no paleo-earthquake preservation
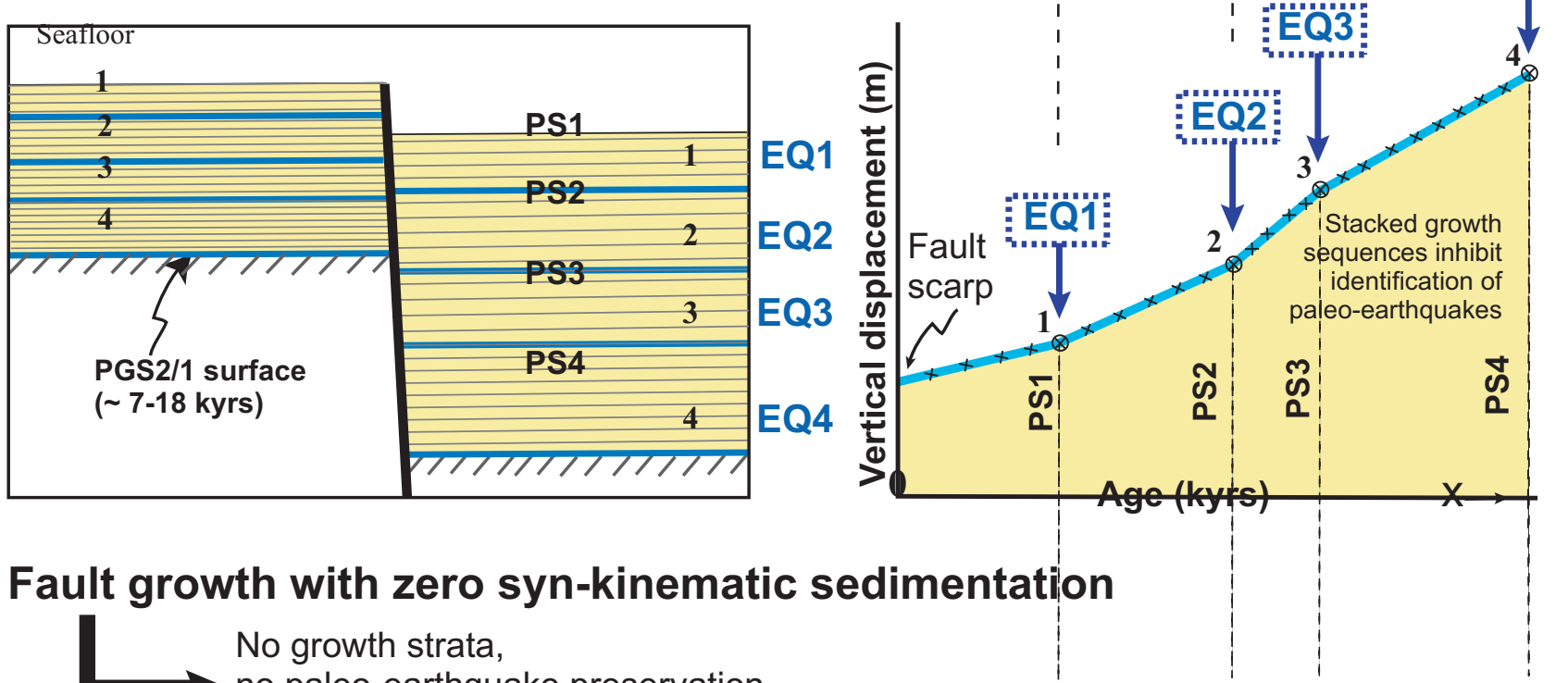

Fault growth with zero syn-kinematic sedimentation

No growth strata,

no paleo-earthquake preservation
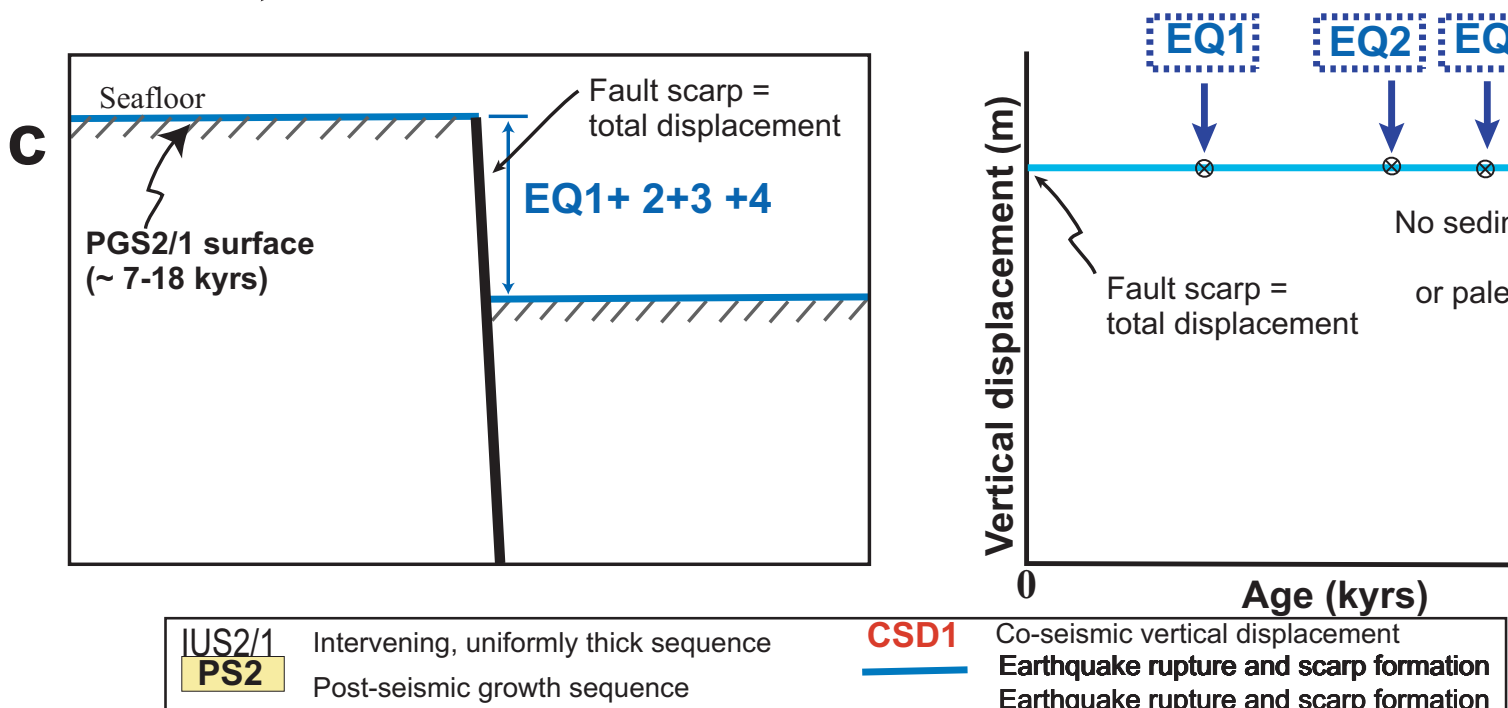

Fig D1) Fig. 1 Barnes \& Pondard [2010] 
2.1

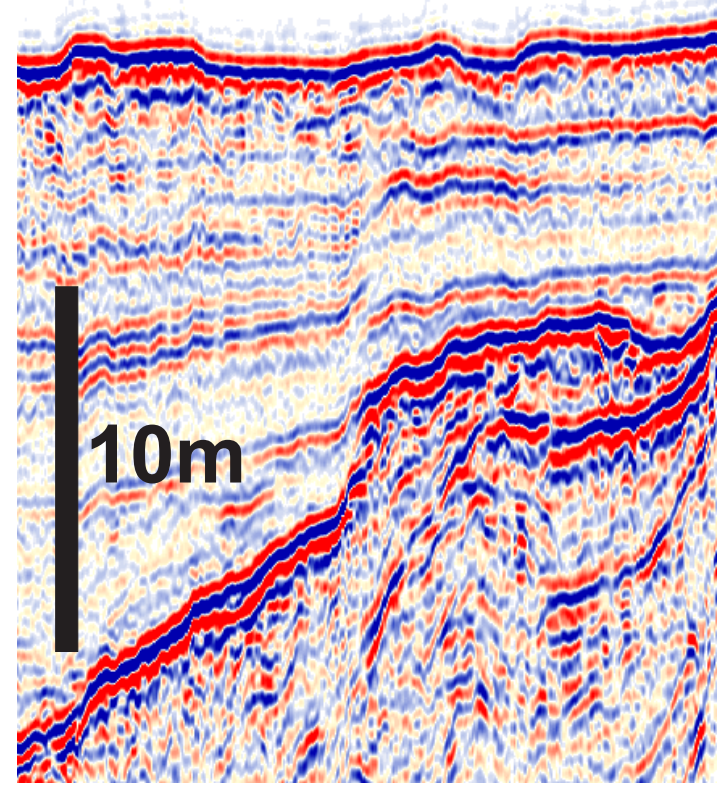

2.2

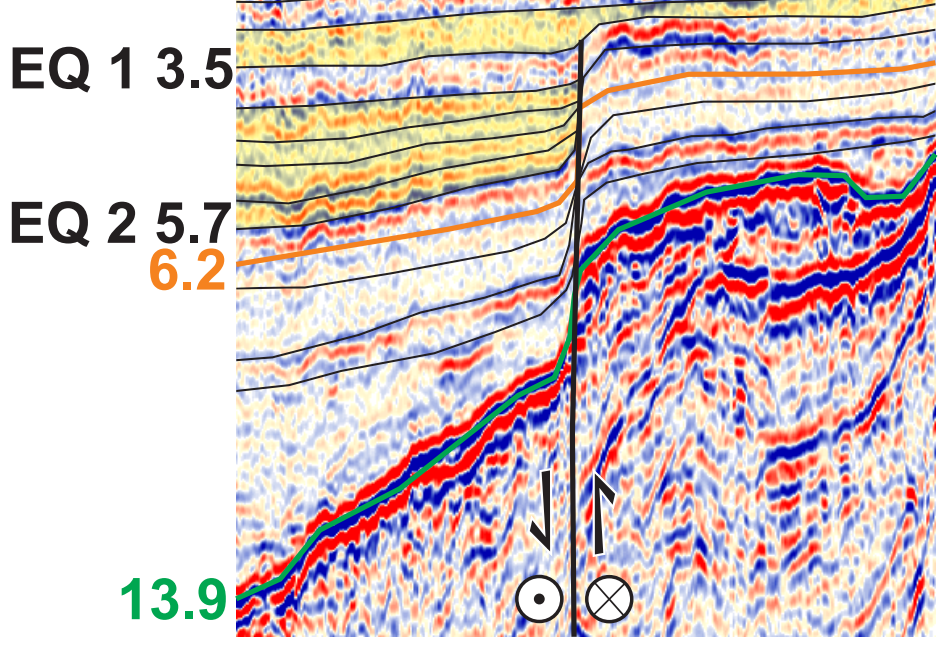

\section{$500 \mathrm{~m}$}

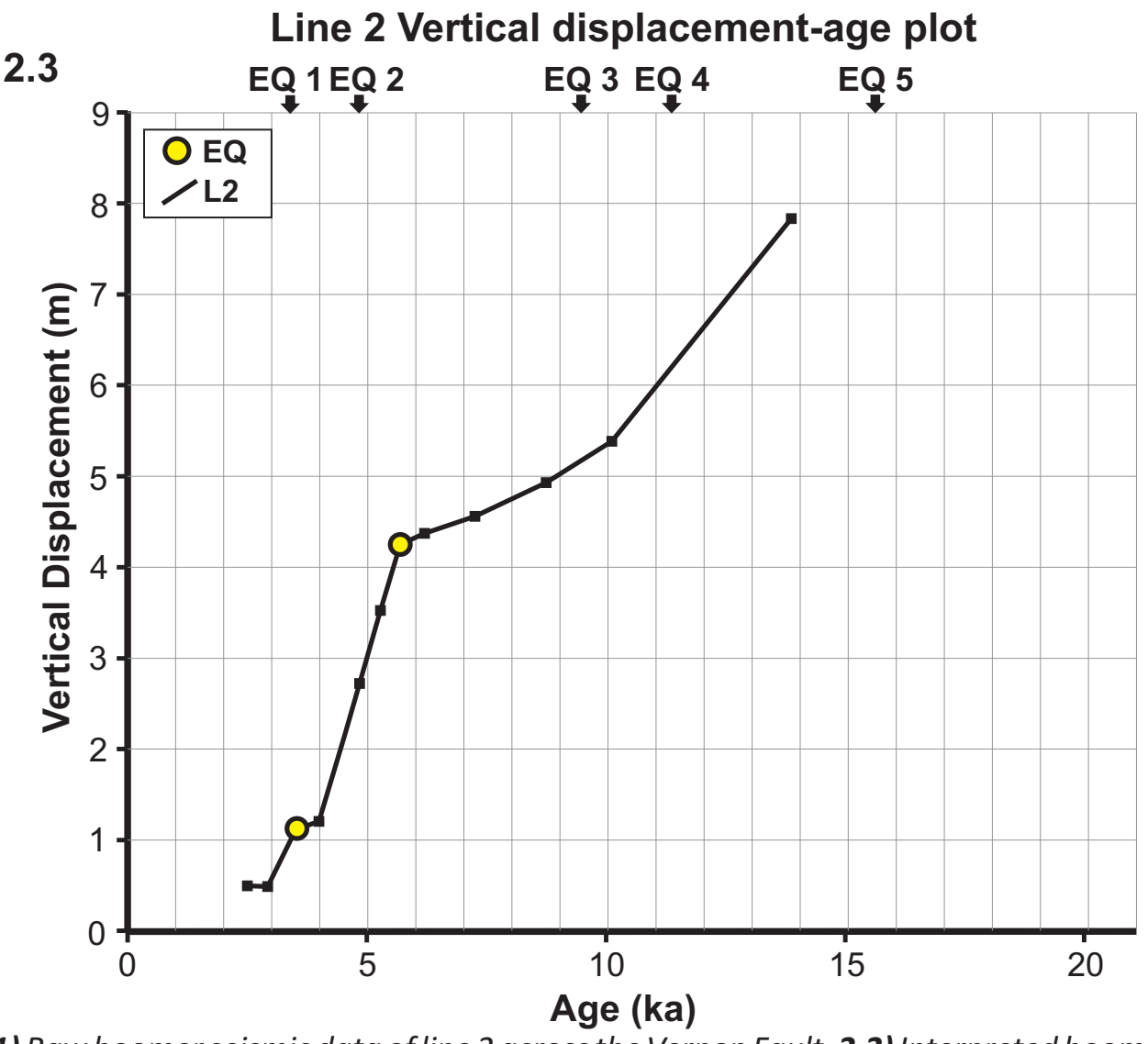

Figure D2.1) Raw boomer seismic data of line 2 across the Vernon Fault. 2.2) Interpreted boomer seismic data of line 2 across the Vernon Fault, showing the fault and the reflectors that cross the fault. The earthquakes occurred when the bottom reflector of the earthquake sequence (yellow areas) was deposited. We used two age constrained reflectors (green and orange) found in the line and absence of the $2.7 \pm 0.6 \mathrm{ka}$ reflector to construct the age model of the sediments at this location. The ages of the reflectors are on the left of the diagrams $(\mathrm{ka})$. 2.3) Vertical displacement-age plot of the Vernon Fault on line 2. Flats of no rise in displacement show no earthquakes, ramps show earthquake sequences. No earthquakes can be resolved from the data before $\sim 5.8 \mathrm{ka}$ although the displacement has risen because the sequence is very compact (smaller than our resolution). 


\section{1}

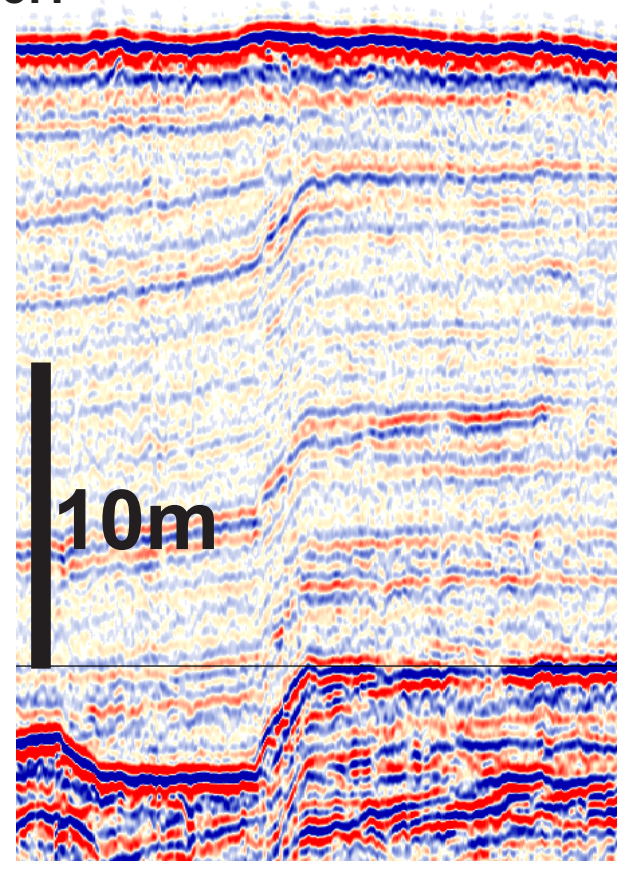

\section{2}

EQ 13.6

EQ 25.1

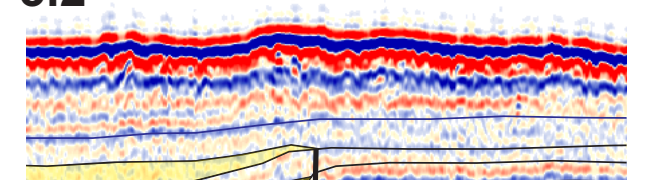

6.2

\section{4}

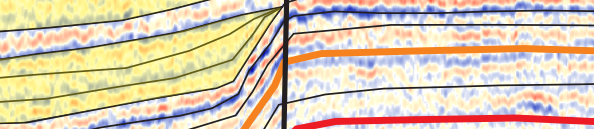

EQ 310

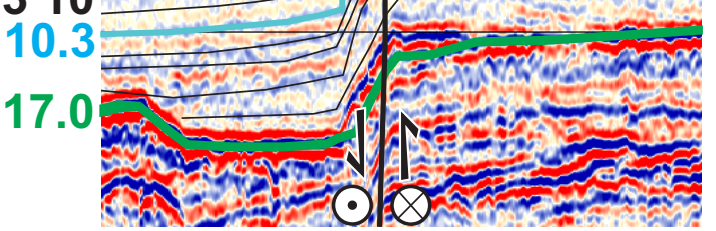

\section{$500 \mathrm{~m}$}

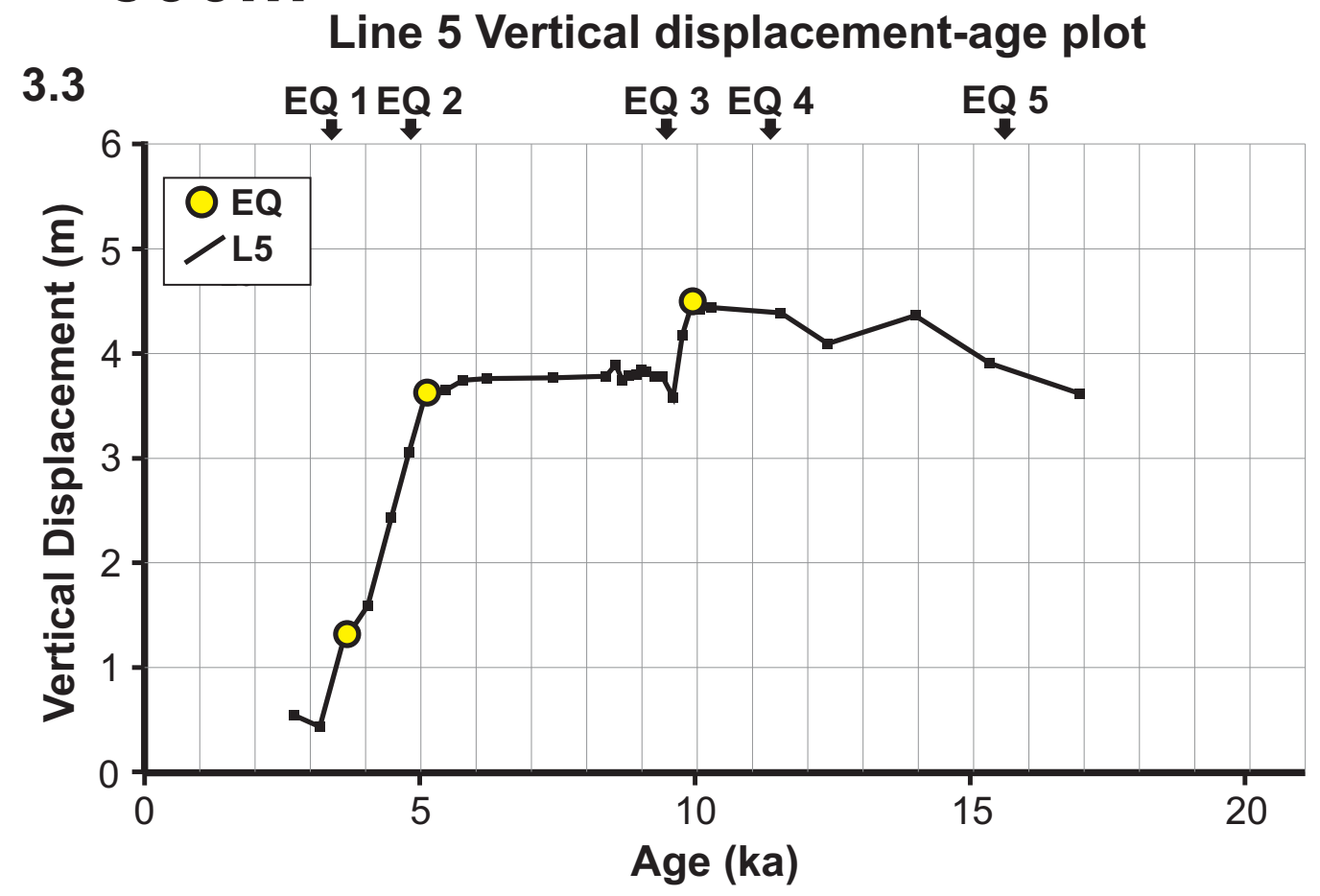

Figure D3.1) Raw boomer seismic data of line 5 across the Vernon Fault. 3.2) Interpreted boomer seismic data of line 5 across the Vernon Fault, showing the fault and the reflectors that cross the fault. The earthquakes occurred when the bottom reflector of the earthquake sequence (yellow areas) was deposited. We used age constrained reflectors (green, turquoise, orange and red) found in the line to construct the age model of the sediments at this location. The ages of the reflectors are on the left of the diagrams (ka). 3.3) Vertical displacement-age plot of the Vernon Fault on line 5. Flats of no rise in displacement show no earthquakes, ramps show earthquake sequences. Three earthquakes have been found on line 5 . 

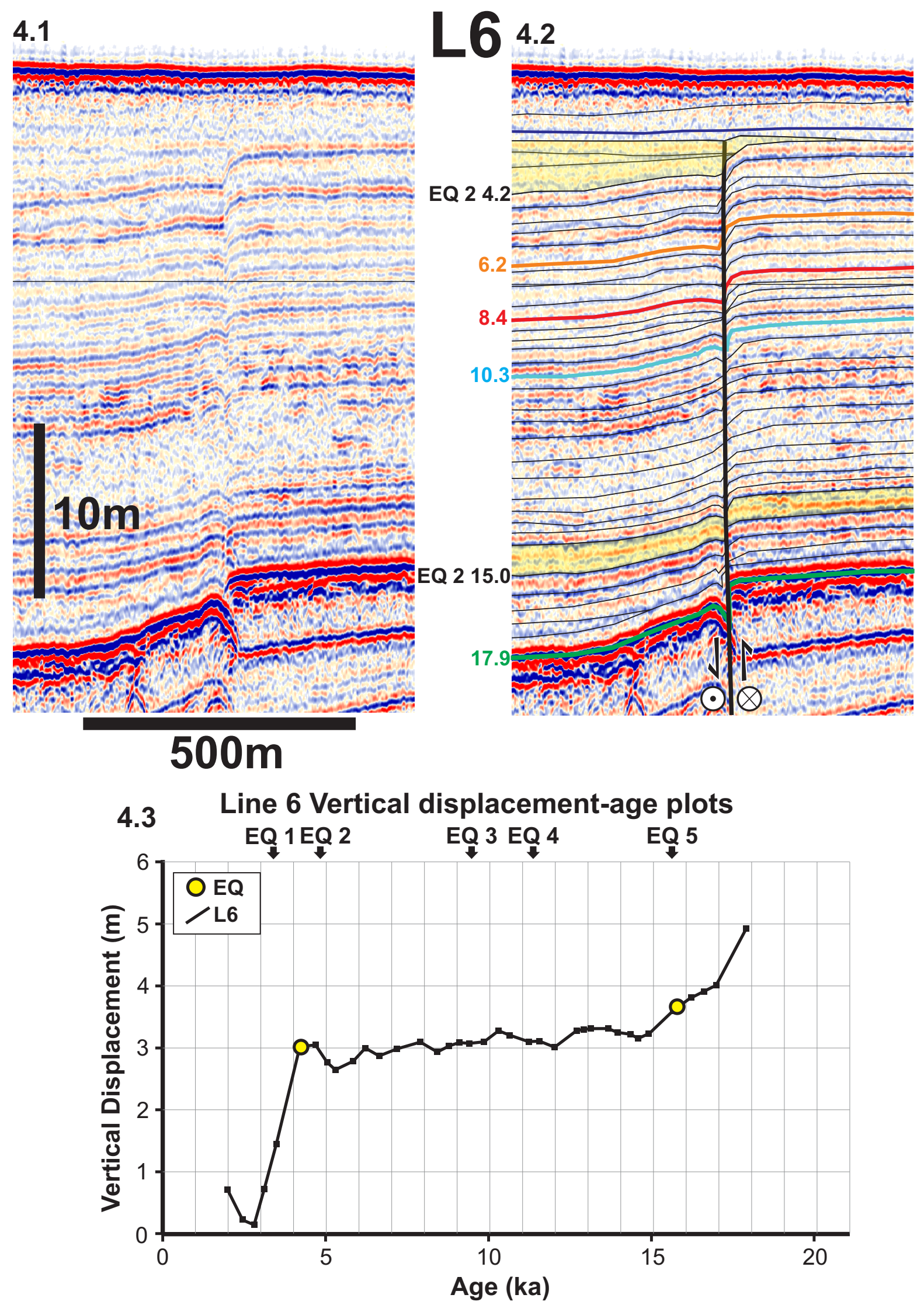

Figure D4.1) Raw boomer seismic data of line 6 across the Vernon Fault. 4.2) Interpreted boomer seismic data of line 6 across the Vernon Fault, showing the fault and the reflectors that cross the fault. The earthquakes occurred when the bottom reflector of the earthquake sequence (yellow areas) was deposited. We used age constrained reflectors (green, turquoise, orange and red) found in the line to construct the age model of the sediments at this location. The ages of the reflectors are on the left of the diagrams (ka). 4.3) Vertical displacement-age plot of the Vernon Fault on line 6. Flats of no rise in displacement show no earthquakes, ramps show earthquake sequences. Two earthquakes have been found on line 5 . 
5.1

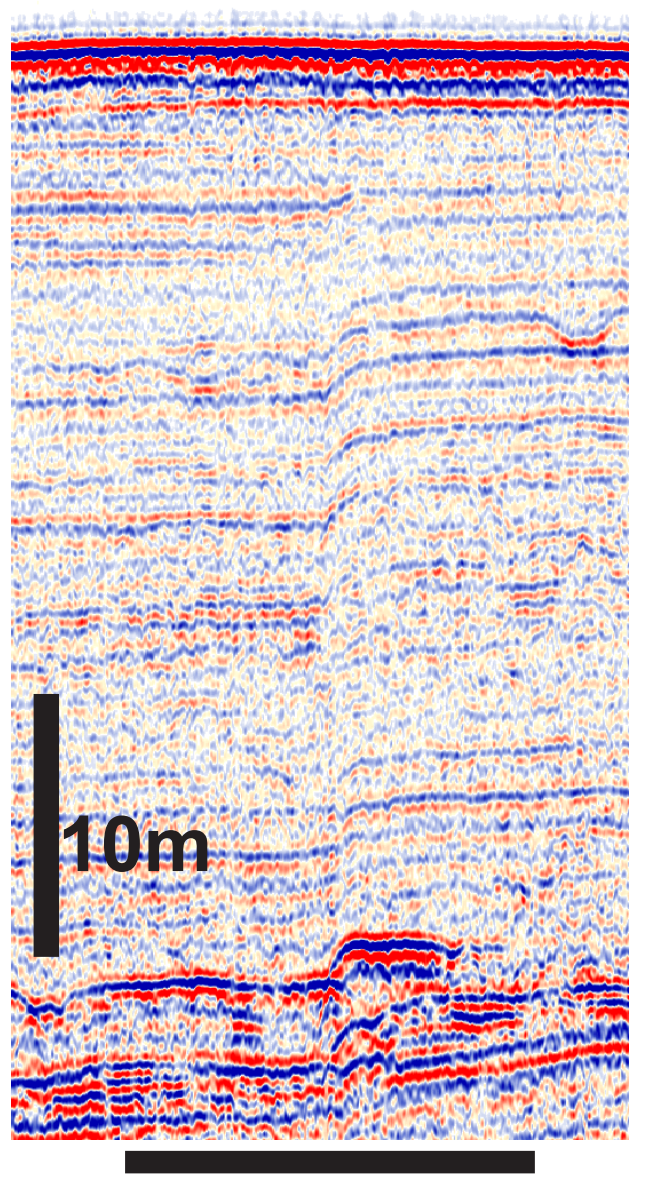

5.2

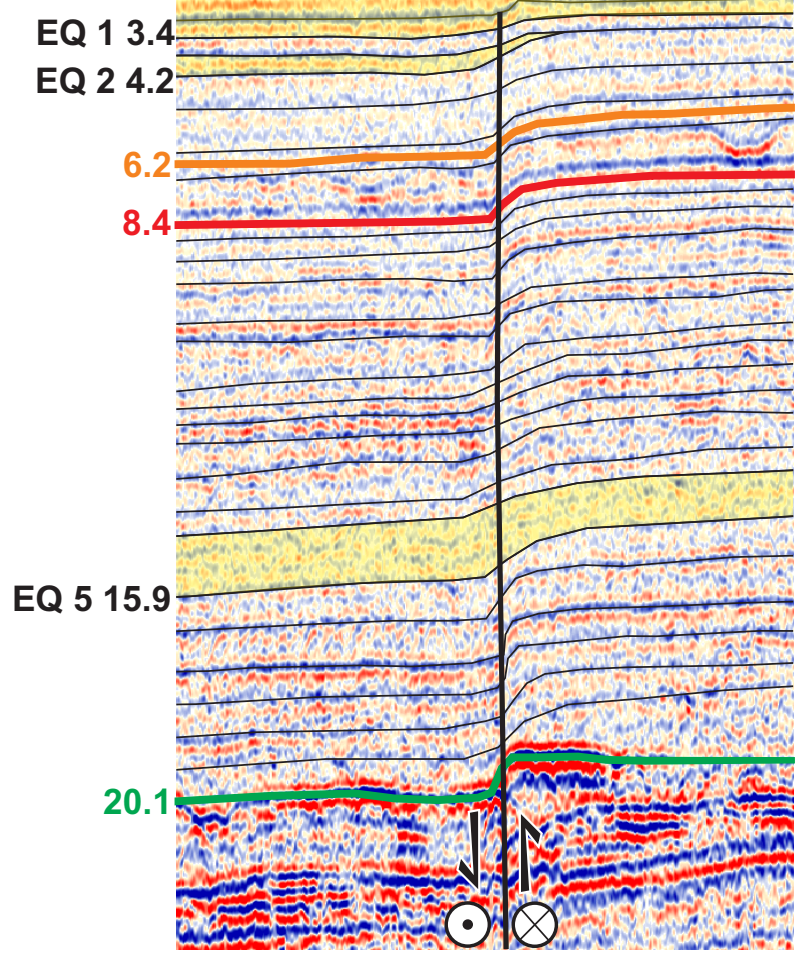

\section{$500 \mathrm{~m}$}

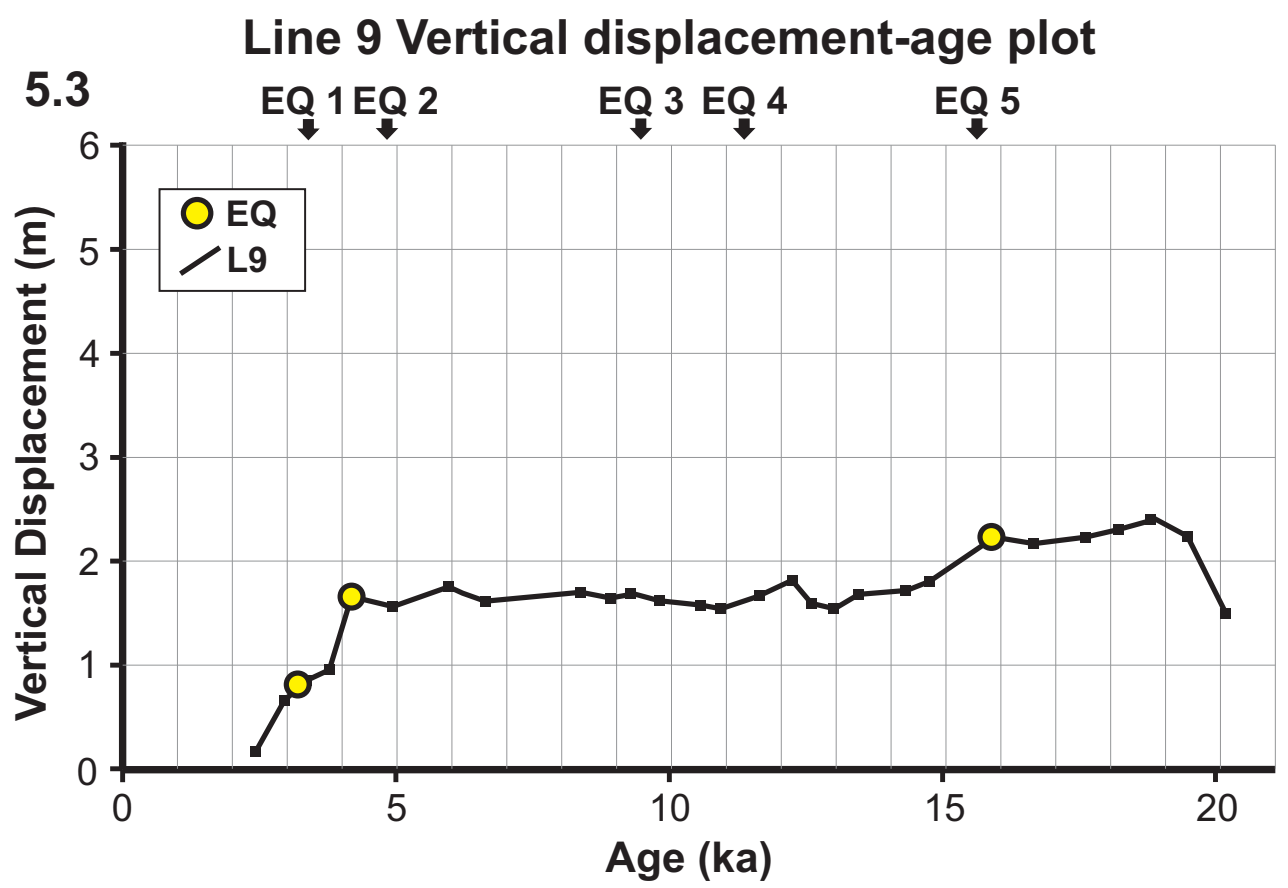

Figure D5.1) Raw boomer seismic data of line 9 across the Vernon Fault. 5.2) Interpreted boomer seismic data of line 9 across the Vernon Fault, showing the fault and the reflectors that cross the fault. The earthquakes occurred when the bottom reflector of the earthquake sequence (yellow areas) was deposited. We used age constrained reflectors (green, orange, and red) found in the line to construct the age model of the sediments at this location. The ages of the reflectors are on the left of the diagrams $(\mathrm{ka})$. 5.3) Vertical displacement-age plot of the Vernon Fault on line 9. Flats of no rise in displacement show no earthquakes, ramps show earthquake sequences. Three earthquakes have been found on line 9. 
6.1

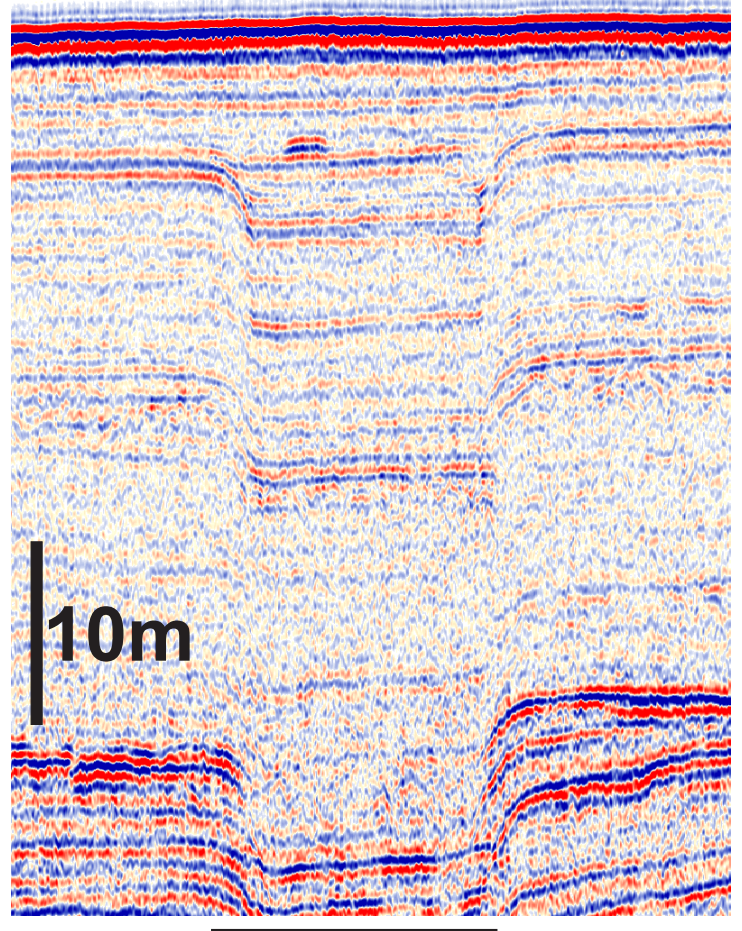

\section{L10 6.2}

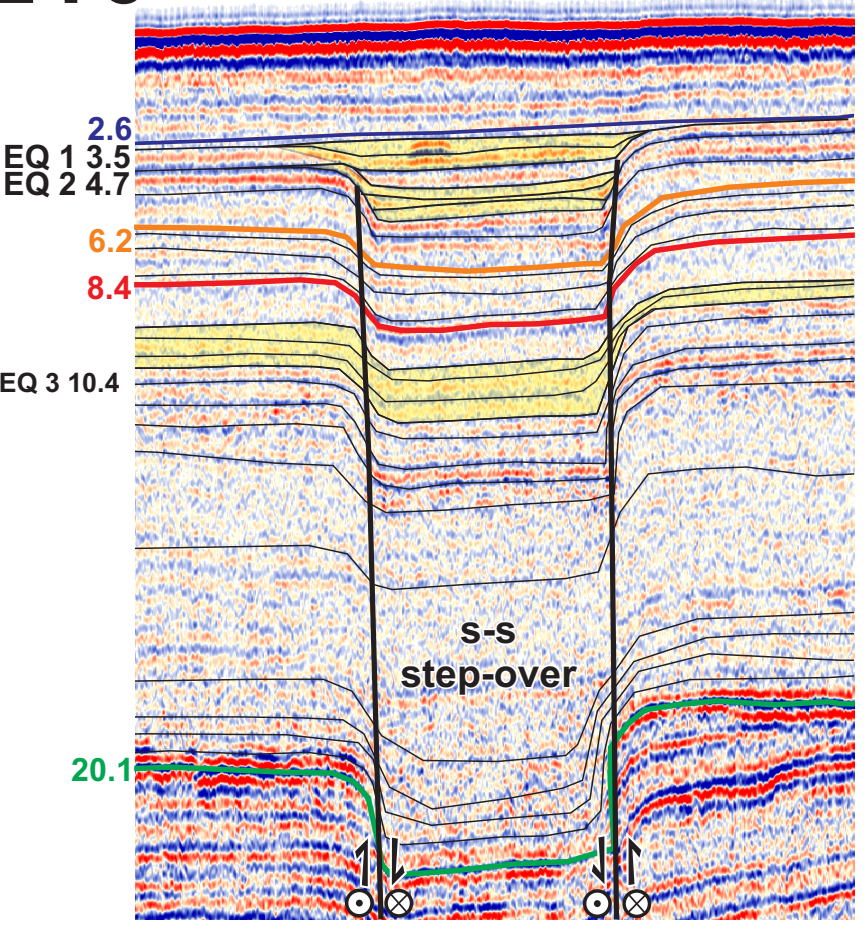

\section{$500 \mathrm{~m}$}

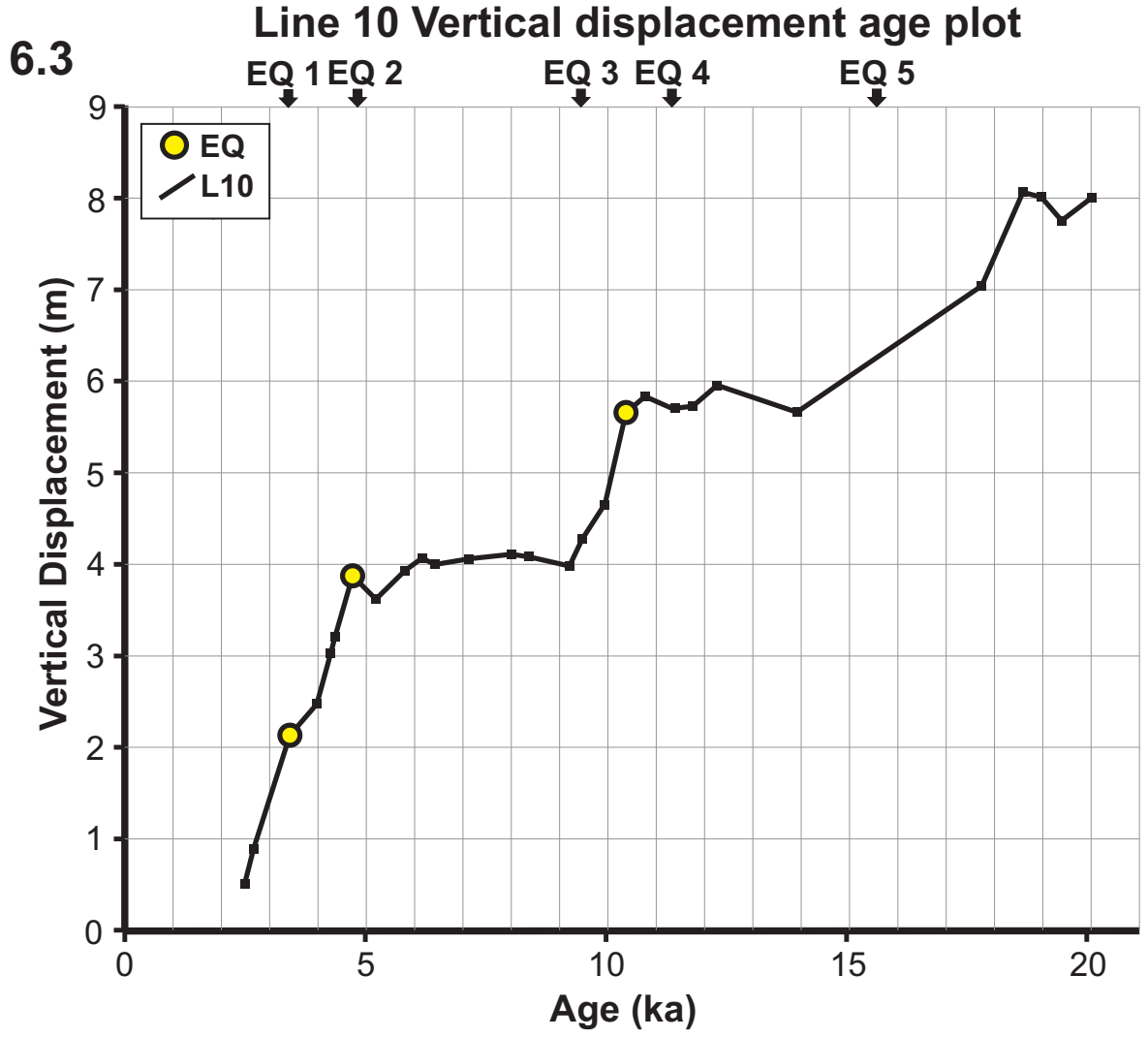

Figure D6.1) Raw boomer seismic data of line 10 across the Vernon Fault. 6.2) Interpreted boomer seismic data of line 10 across two splays of the Vernon Fault graben, showing the splays and the reflectors that cross the splays. The earthquakes occurred when the bottom reflector of the earthquake sequence (yellow areas) was deposited. We used age constrained reflectors (green, orange, red, and blue) found in the line to construct an age model of the sediments at this location. The ages of the reflectors are on the left of the diagrams (ka). 6.3) Vertical displacement-age plot of the Vernon Fault on line 10. Flats of no rise in displacement show no earthquakes, ramps show earthquake sequences. Three earthquakes have been found on line 10. 


\section{1}

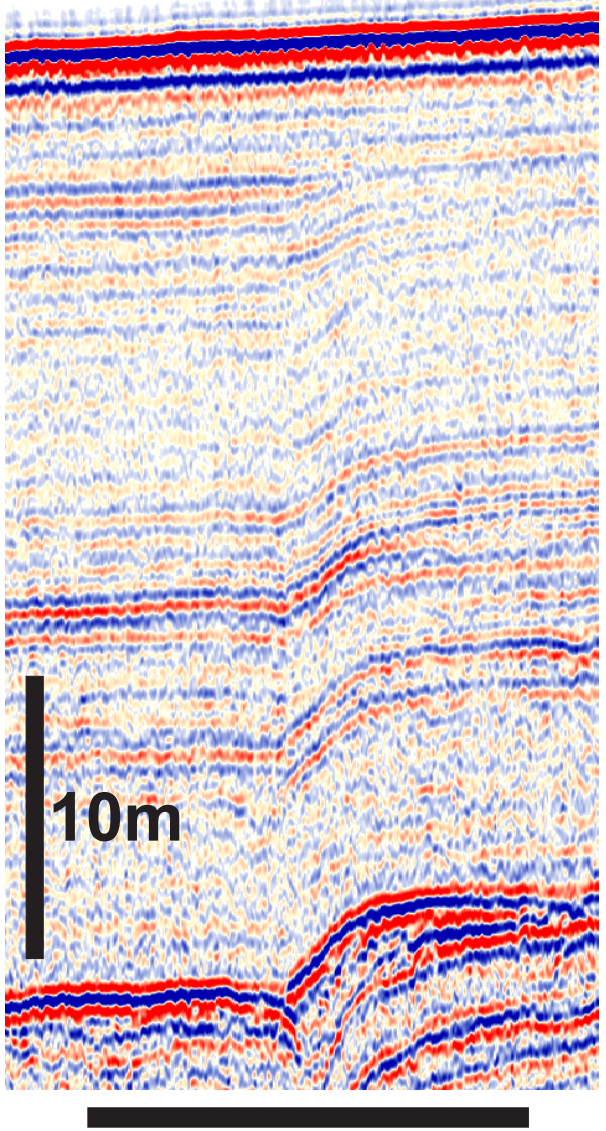

$117^{7.2}$
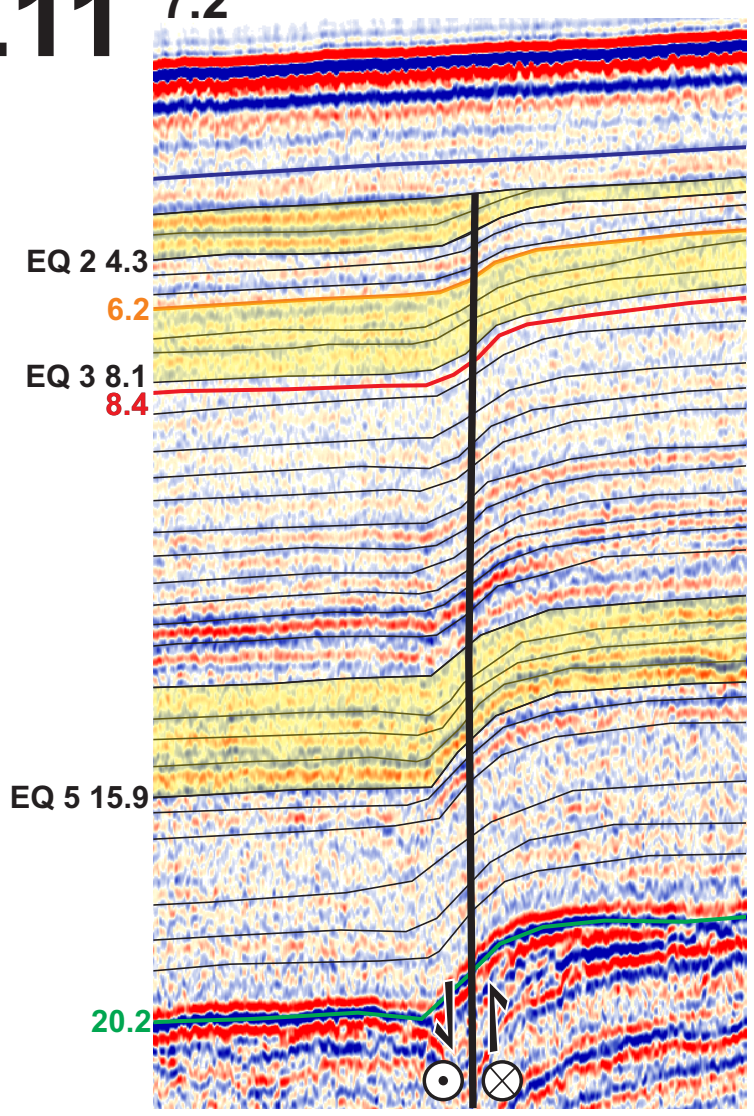

$500 \mathrm{~m}$

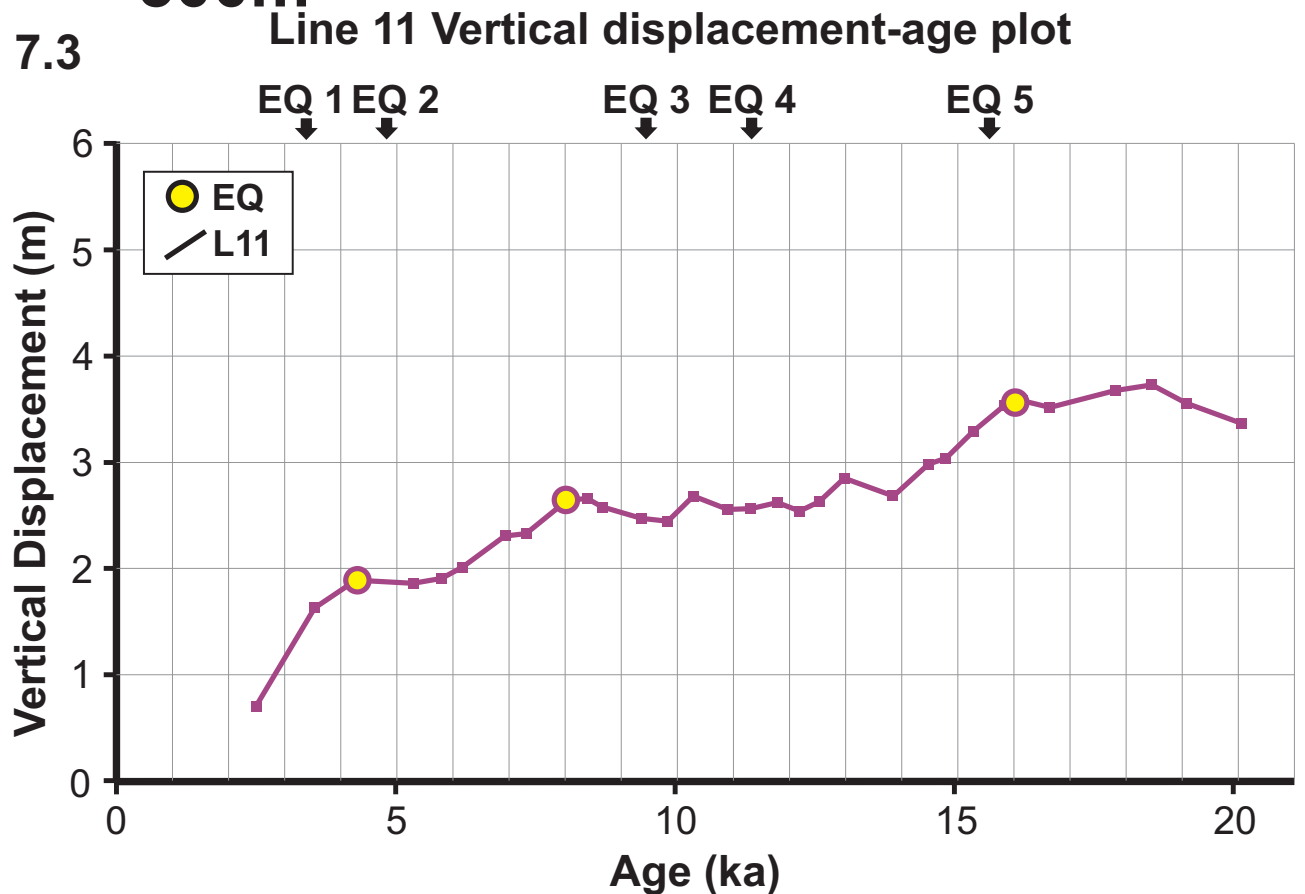

Figure D7.1) Raw boomer seismic data of line 11 across the Vernon Fault. 7.2) Interpreted boomer seismic data of line 11 across the Vernon Fault, showing the fault and the reflectors that cross the fault. The earthquakes occurred when the bottom reflector of the earthquake sequence (yellow areas) was deposited. We used age constrained reflectors (green, orange, red, and blue) found in the line to construct an age model of the sediments at this location. The ages of the reflectors are on the left of the diagrams (ka). 7.3) Vertical displacement-age plot of the Vernon Fault on line 11. Flats of no rise in displacement show no earthquakes, ramps show earthquake sequences. Three earthquakes have been found on line 11. 

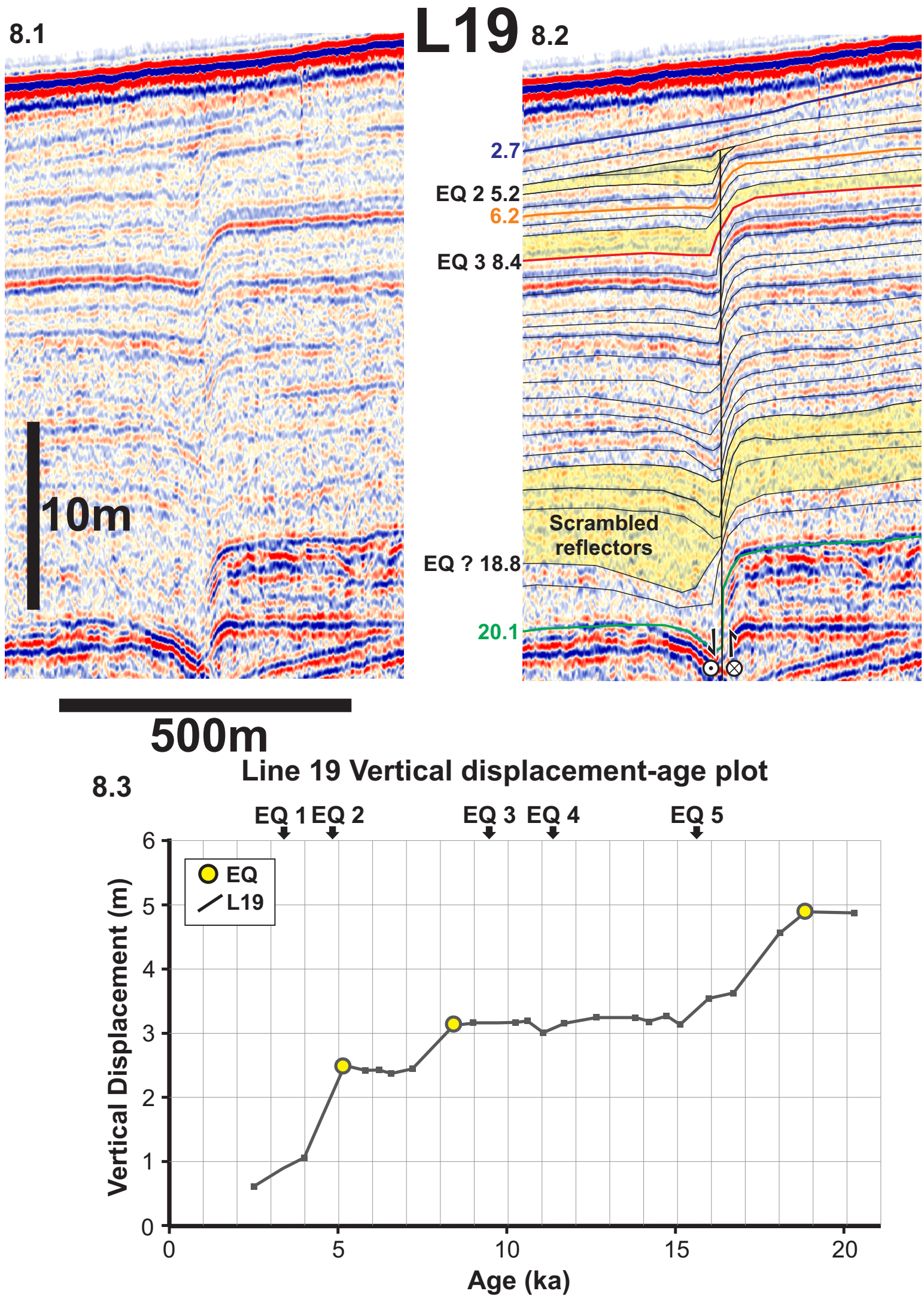

Figure D8.1) Raw boomer seismic data of line 12 across the Vernon Fault. 8.2) Interpreted boomer seismic data of line 19 across the Vernon Fault, showing the fault and the reflectors that cross the fault. The earthquakes occurred when the bottom reflector of the earthquake sequence (yellow areas) was deposited. We used age constrained reflectors (green, orange, red, and blue) found in the line to construct an age model of the sediments at this location. The ages of the reflectors are on the left of the diagrams $(\mathrm{ka})$. The reflectors are scrambled in the lower part of the section affecting resolution and the reflector picks. 8.3) Vertical displacement-age plot of the Vernon Fault on line 19. Flats of no rise in displacement show no earthquakes, ramps show earthquake sequences. Three earthquakes have been found on line 19. 


\section{Appendix E: Extra offshore seismic profiles}

The following pages show the boomer seismic data that run across splays of the Vernon and Awatere faults offshore that are not shown within the chapters. Each page shows an uninterpreted and interpreted version of each boomer seismic line with vertical exaggerations of 32 . The interpreted version shows the faults, reflectors with modelled ages, and other structural/stratigraphic interpretations. 


\section{L2}

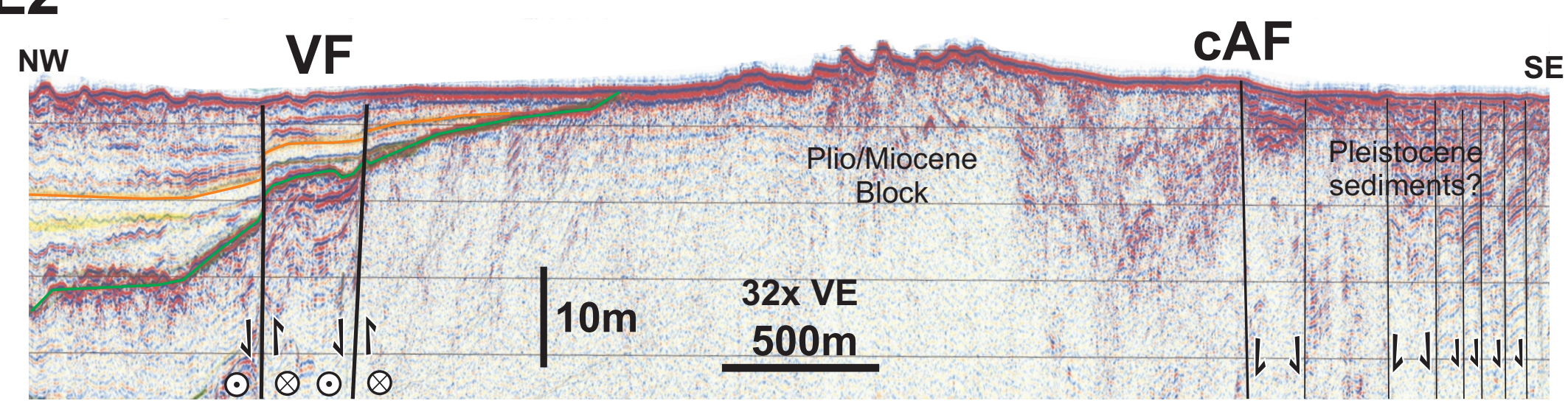

Figure E1) Boomer seismic profile from line 2 (Fig. 1, Chapters 1 and 2), showing the Vernon and coastal Awatere Faults. A PlioceneMiocene reef is exposed between the Vernon and Awatere Faults while Quaternary sediments outcrop north of the Vernon Fault (particularly post last glacial sediments, above the post last glacial ravinement green reflector). To the south of the coastal Awatere Fault the reflectors are less steep, signifying the formation is younger then the Miocene-Pliocene reef, probably earlier Quaternary deposits shelf deposits. The age of the green reflector is $13.9 \pm 0.6 \mathrm{ka}$ and the age of the orange reflector is $6.2 \pm 1.1 \mathrm{ka}$. 


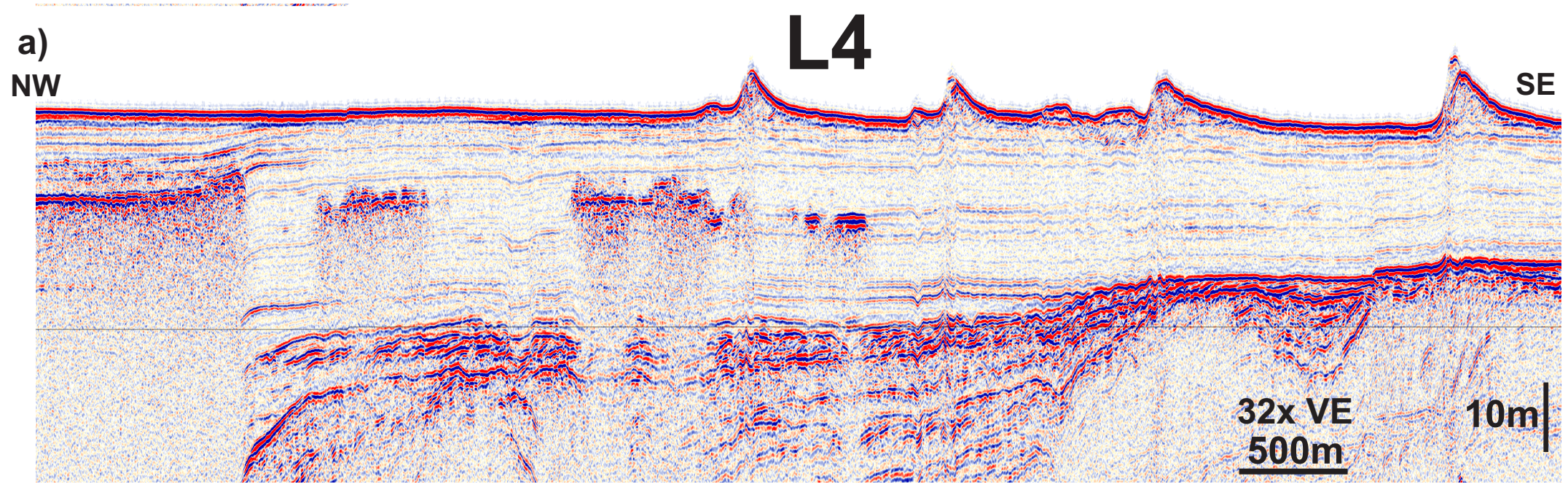

b)

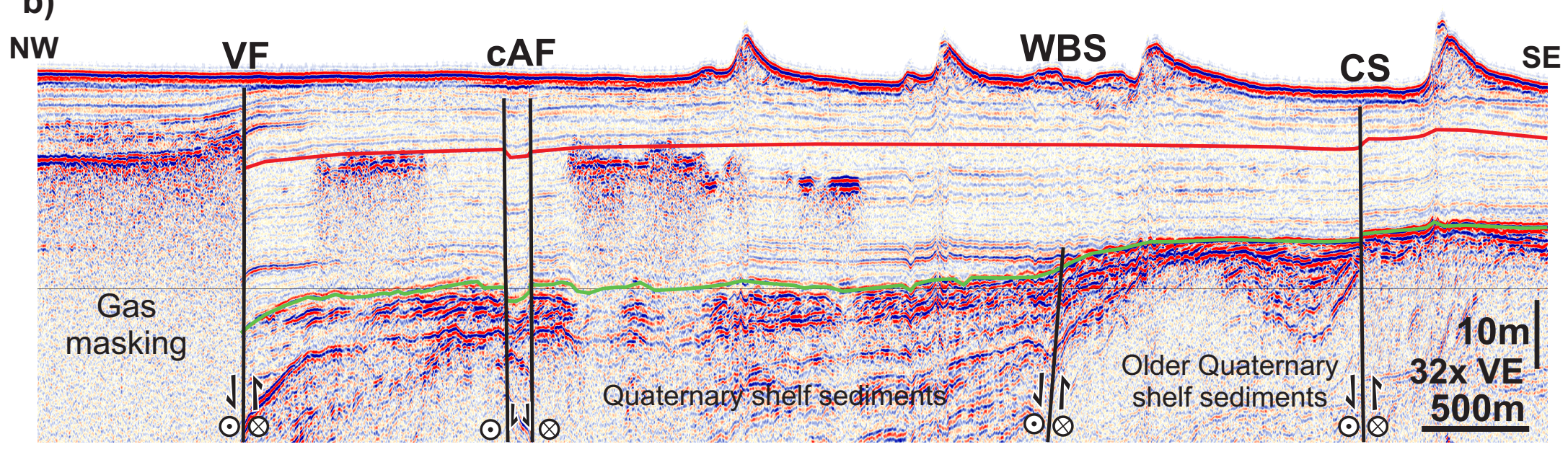

Figure E2a) Un-interpreted boomer seismic profile from line 4 (Fig. 1, Chapters 1 and 2). b) Interpreted boomer seismic profile from line 4 showing the Vernon (VF) and coastal Awatere (CAF) Faults; and the White Bluffs (WBS) and Castlebrae (CS) splays. Here the White Bluffs and Castlebrae splays overlap the coastal Awatere Fault, as slip is transferred onto the splays from the fault. Post-glacial sediments (above the green reflector) drape the older Quaternary shelf sediments in the NW which in turn onlap still older Quaternary sediments SE of the White Bluffs splay. The current has created large $<10 \mathrm{~m}$ sand waves on the sea-floor. The presence of gas pockets in the stratigraphy causes gas masking NW of the Vernon Fault. The age of the green reflector is $16.4 \pm 0.8 \mathrm{ka}$ and the red reflector is $8.4 \pm 1.6 \mathrm{ka}$. 


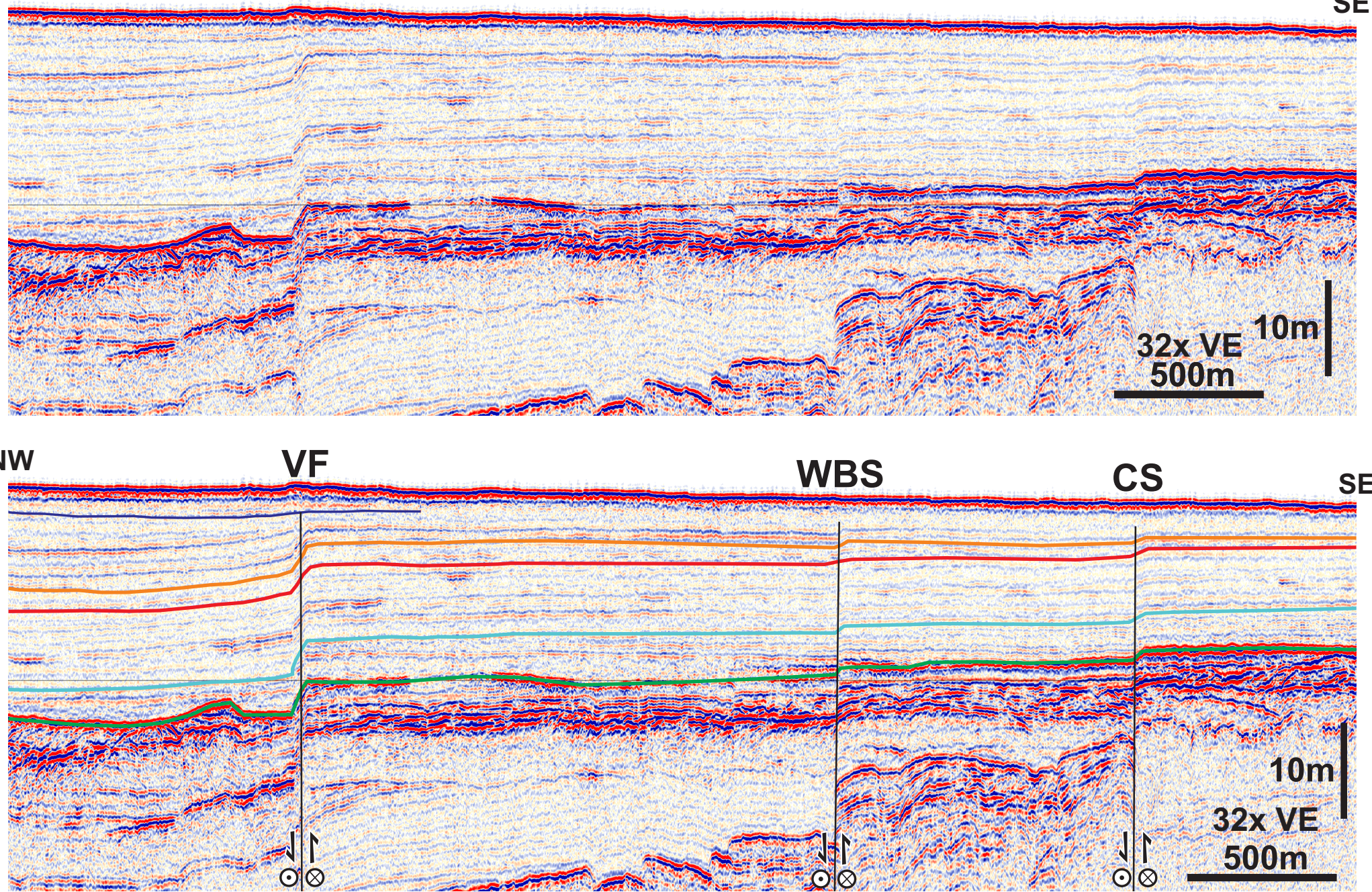

Figure E3a) Un-interpreted boomer seismic profile from line 5 (Fig. 1, Chapters 1 and 2). b) Interpreted boomer seismic profile from line 5 showing the Vernon Fault (VF) and the White Bluffs (WBS) and Castlebrae (CS) splays. The White Bluffs and Castlebrae splays accommodate most of the slip from the coastal Awatere Fault to the west. Post-glacial sediments (above the green reflector) drape older Quaternary shelf sediments in the NW which in turn onlap still older Quaternary sediments SE of the White Bluffs splay. The age of the green reflector is $17.0 \pm 0.9 \mathrm{ka}$, the turquoise reflector is $10.3 \pm 2.1 \mathrm{ka}$, the red reflector is $8.4 \pm 1.6 \mathrm{ka}$, and the orange reflector is $6.2 \pm 1.1 \mathrm{ka}$. The basin thickens towards the NW. 

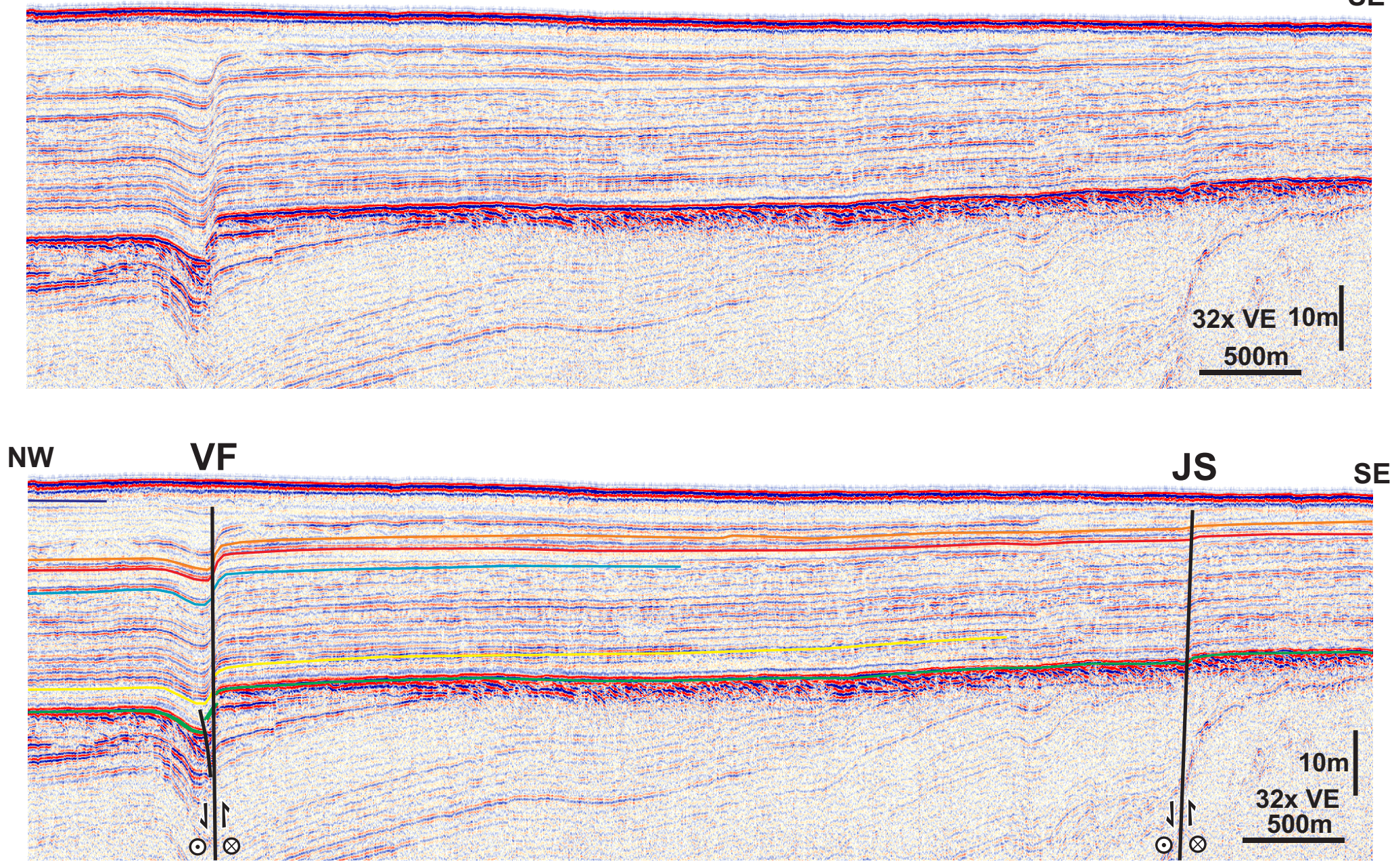

Figure E4a) Un-interpreted boomer seismic profile from line 7 (Fig. 1, Chapters 1 and 2). b) Interpreted boomer seismic profile from line 7 showing the Vernon Fault (VF) and the Jedburgh splay(CS). The Jedburgh splay accommodates most of the slip from the White Bluffs and Castlebrae splay to the west. Post-glacial sediments (above the green reflector) drape older, more deformed Quaternary shelf sediments. The age of the green reflector is $19.3 \pm 0.5 \mathrm{ka}$, the yellow reflector is $14.0 \pm 3.8 \mathrm{ka}$, the turquoise reflector is $10.3 \pm 2.1 \mathrm{ka}$, the red reflector is $8.4 \pm 1.6 \mathrm{ka}$, and the orange reflector is $6.2 \pm 1.1 \mathrm{ka}$. The yellow and turquoise reflectors terminate south-eastwards as they onlap slight angular unconformities. 

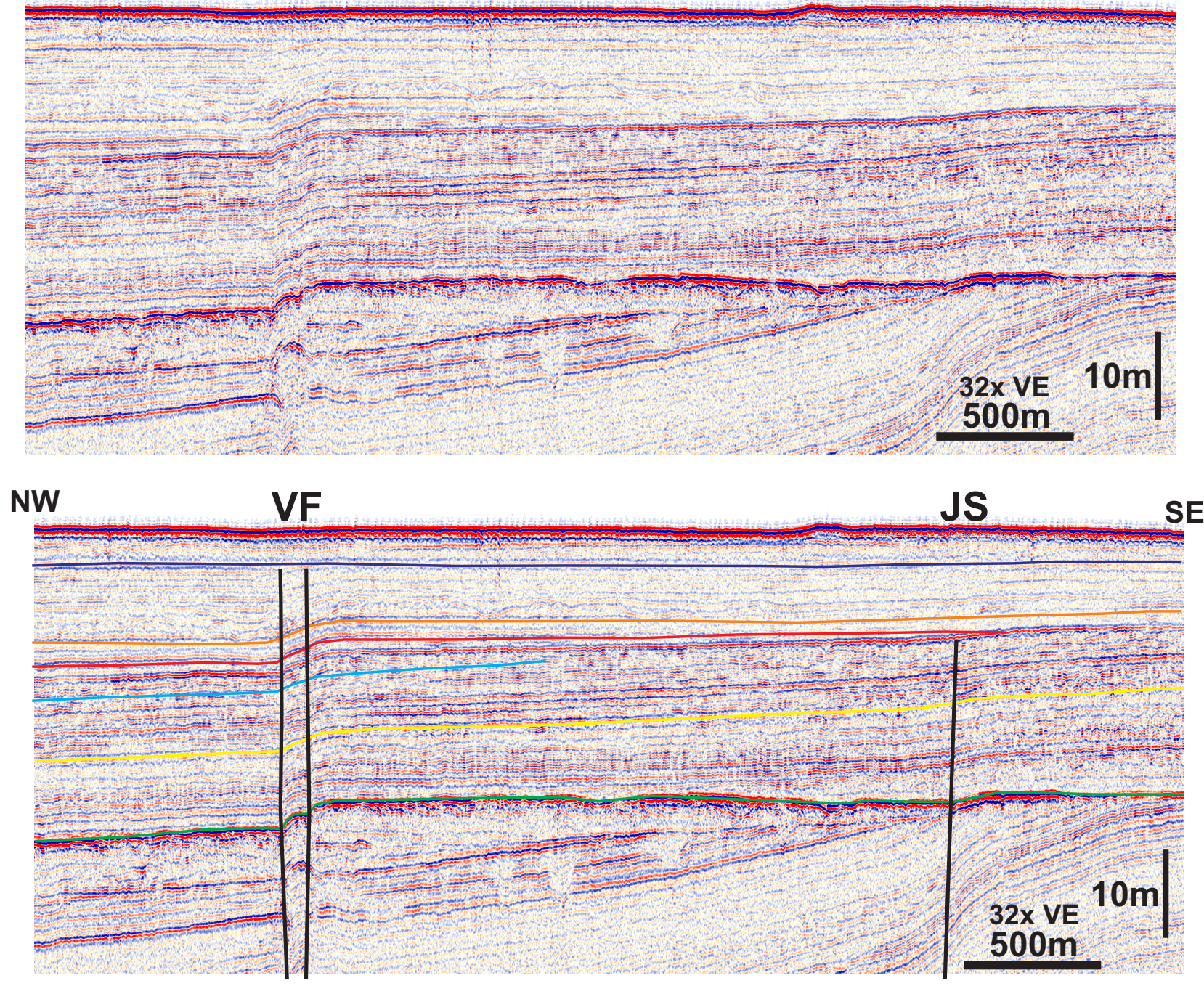

Figure E5a) Un-interpreted boomer seismic profile from line 8(Fig. 1, Chapters 1 and 2). b) Interpreted boomer seismic profile from line 8 showing the Vernon Fault (VF) and the Jedburgh splay (JS). The Jedburgh splay accommodates most of the slip from the White Bluffs and Castlebrae splay to the west. Post-glacial sediments (above the green reflector) drape older Quaternary shelf sediments unconformably. The yellow, turquoise, and red reflectors terminate south-eastwards as they onlap slight angular unconformities. The age of the green reflector is $19.3 \pm 0.5 \mathrm{ka}$, the yellow reflector is $14.0 \pm 3.8 \mathrm{ka}$, the turquoise reflector is $10.3 \pm 2.1 \mathrm{ka}$, the red reflector is $8.4 \pm 1.6 \mathrm{ka}$, and the orange reflector is $6.2 \pm 1.1 \mathrm{ka}$. 

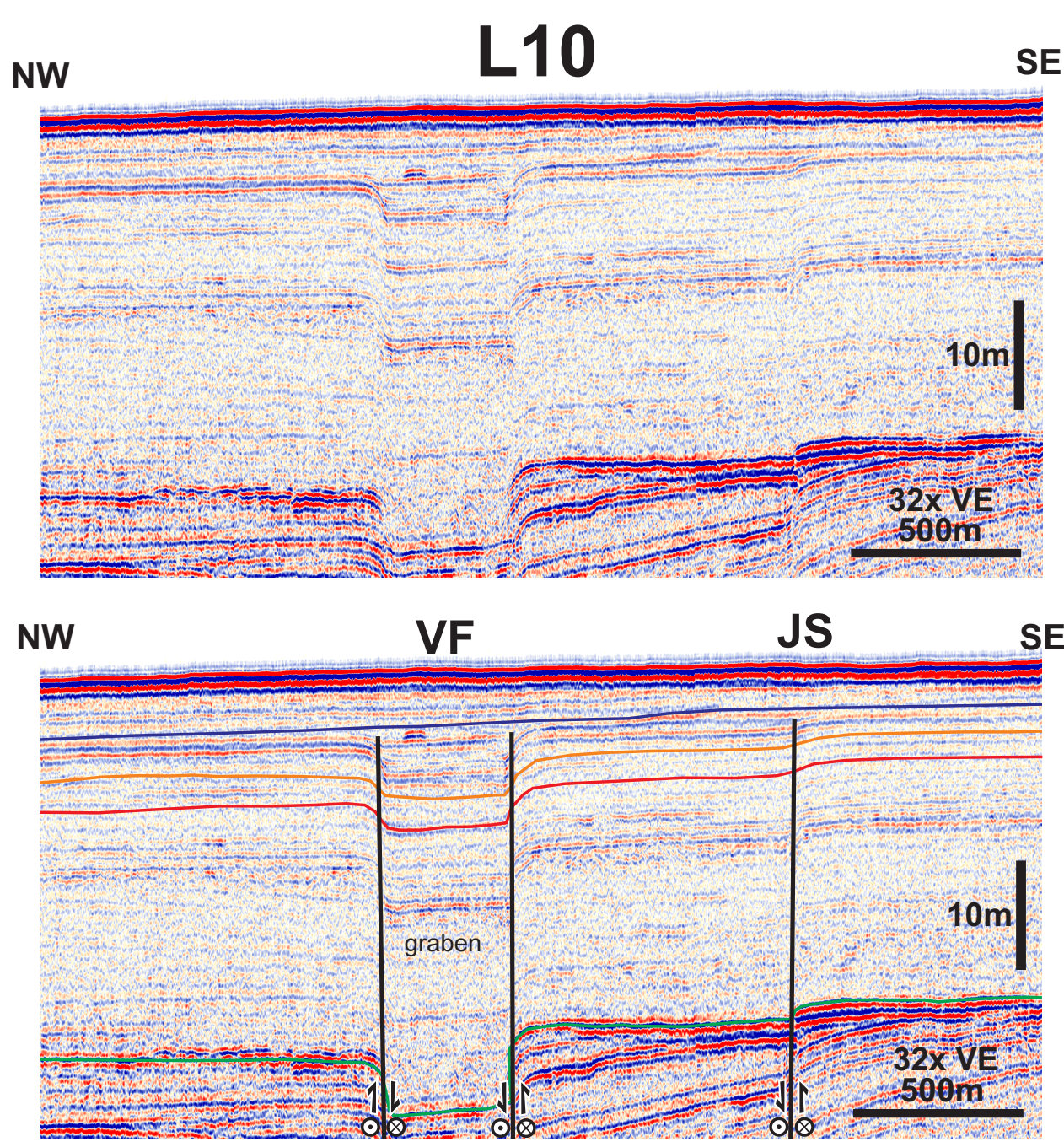

Figure E6a) Un-interpreted boomer seismic profile from line 10 (Fig. 1, Chapters 1 and 2). b) Interpreted boomer seismic profile from line 10 showing the Vernon Fault (VF) and the Jedburgh splay(CS). The Vernon Fault is a $400 \mathrm{~m}$ wide step-over graben in this profile. The Jedburgh splay is closer to the Vernon Fault than it is to the west. Post-glacial sediments (above the green reflector) drape older Quaternary shelf sediments unconformably. The age of the green reflector is $20.1 \pm 0.3 \mathrm{ka}$, the red reflector is $8.4 \pm 1.6 \mathrm{ka}$, and the orange reflector is $6.2 \pm 1.1$ $k a$, and the blue reflector is $2.7 \pm 0.6 \mathrm{ka}$. 


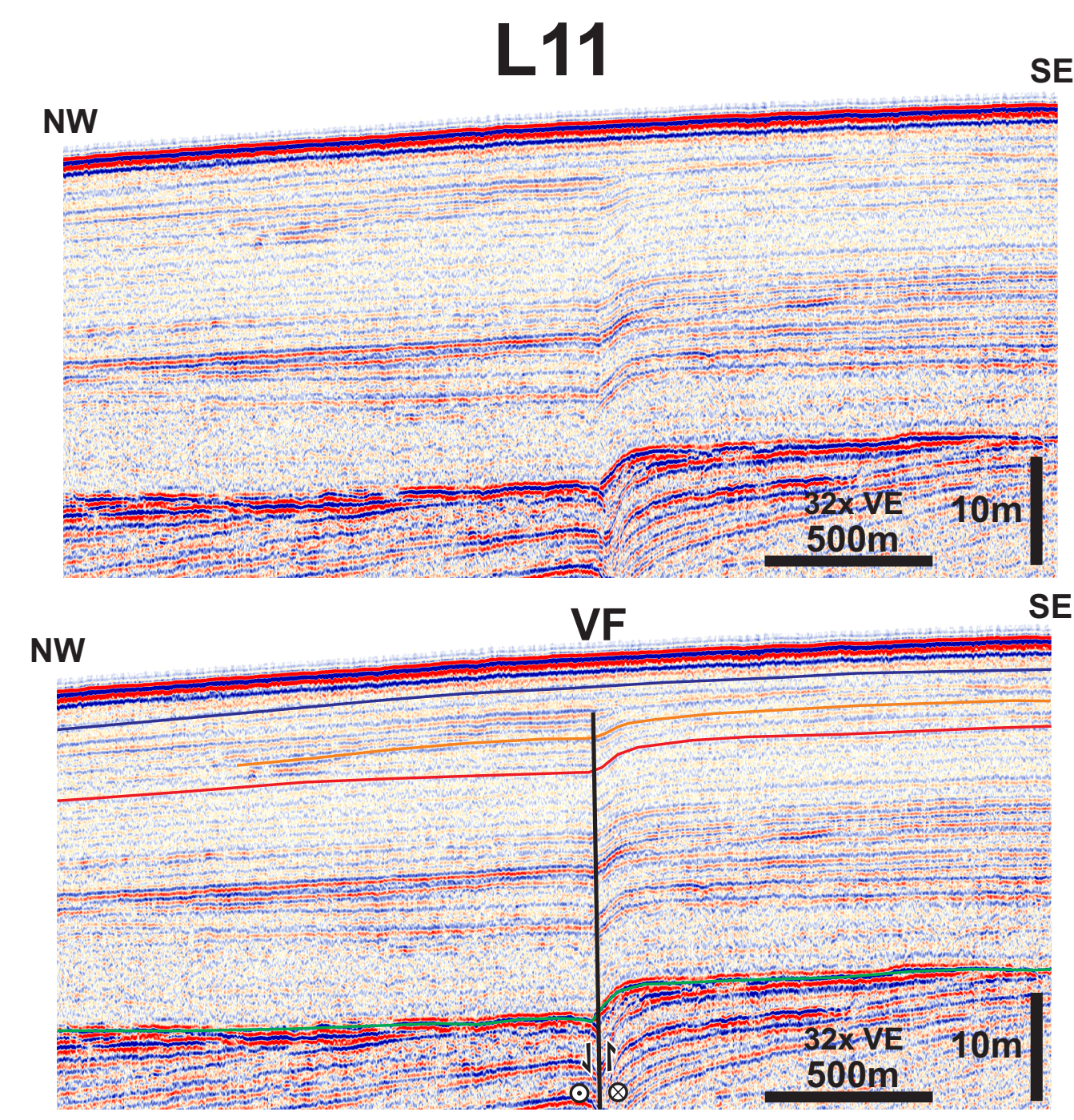

Figure E7a) Un-interpreted boomer seismic profile from line 11 (Fig. 1, Chapters 1 and 2). b) Interpreted boomer seismic profile from line 11 showing the Vernon Fault (VF). Splays of the coastal Awatere Fault have terminated to the west with only the Vernon Fault imaged. Postglacial sediments (above the green reflector) drape older Quaternary shelf sediments unconformably. The age of the green reflector is 20.2 $\pm 0.3 \mathrm{ka}$, the red reflector is $8.4 \pm 1.6 \mathrm{ka}$, and the orange reflector is $6.2 \pm 1.1 \mathrm{ka}$, and the blue reflector is $2.7 \pm 0.6 \mathrm{ka}$. 

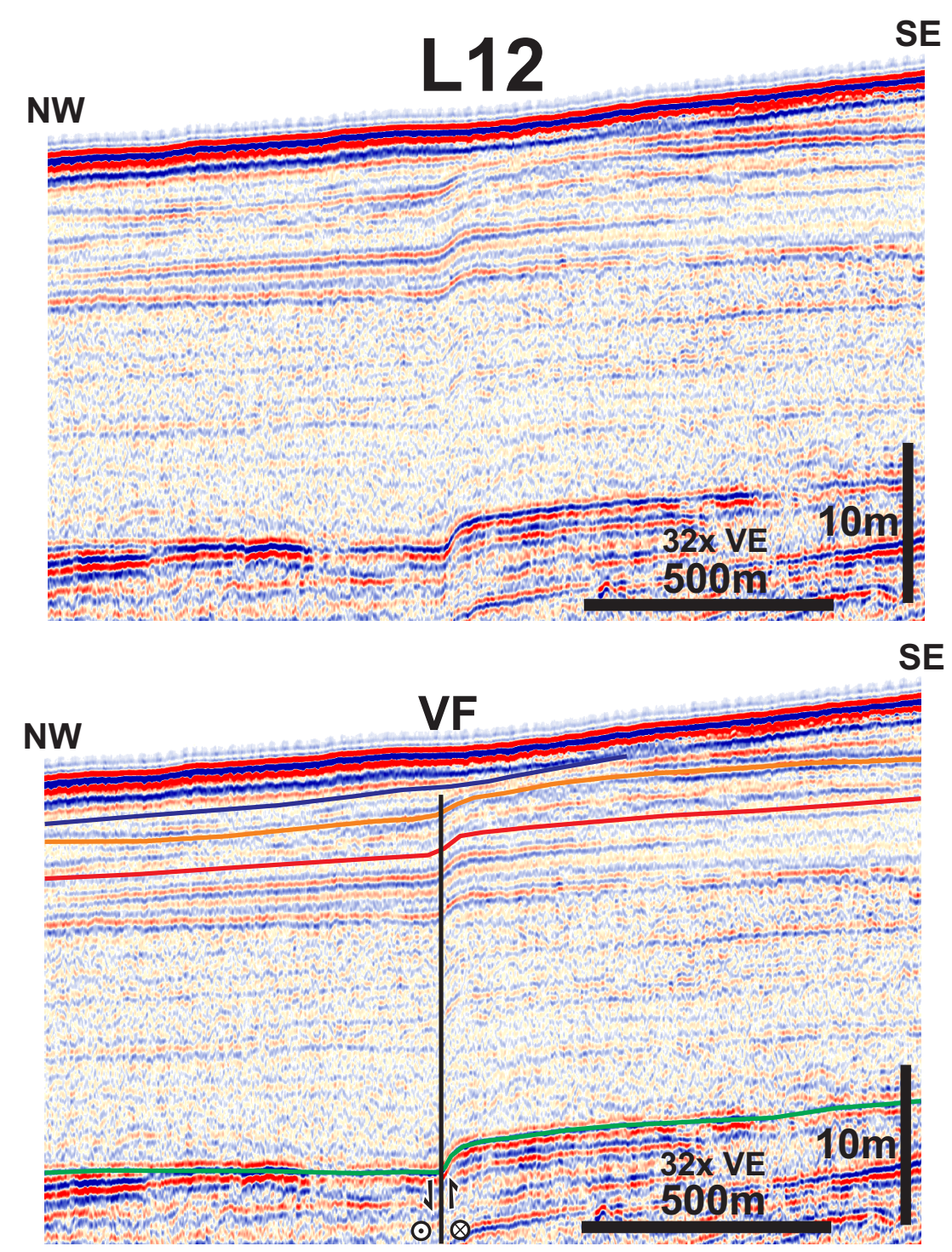

Figure E8a) Un-interpreted boomer seismic profile from line 12 (Fig. 1, Chapters 1 and 2). b) Interpreted boomer seismic profile from line 12 showing the Vernon Fault (VF). Splays of the coastal Awatere Fault have terminated to the west with only the Vernon Fault imaged. Postglacial sediments (above the green reflector) drape older Quaternary shelf sediments unconformably. The age of the green reflector is 20.3 $\pm 0.3 \mathrm{ka}$, the red reflector is $8.4 \pm 1.6 \mathrm{ka}$, and the orange reflector is $6.2 \pm 1.1 \mathrm{ka}$, and the blue reflector is $2.7 \pm 0.6 \mathrm{ka}$. 


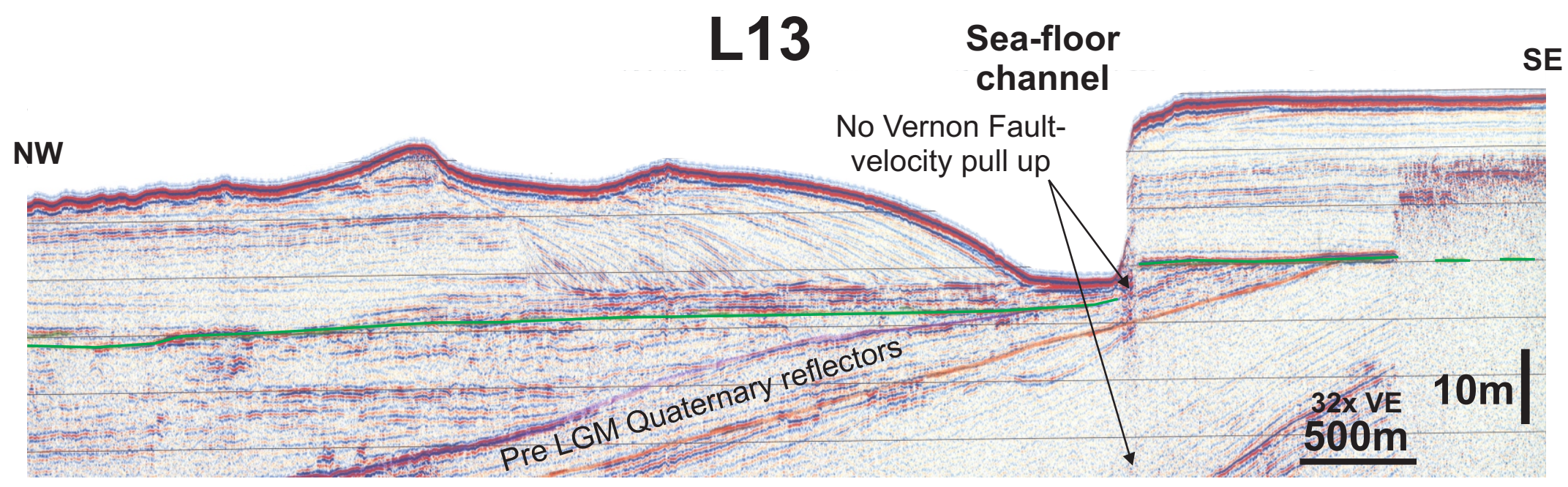

Figure E9) Interpreted boomer seismic profile from line 13 (Fig. 1, Chapters 1 and 2) showing the lack offaulting in the profile. The apparent discontinuity of reflectors underneath the SW bank of the sea-floor channel is caused by a velocity pull-down affect. Post-glacial sediments (above the green reflector) drape older Quaternary shelf sediments unconformably. 

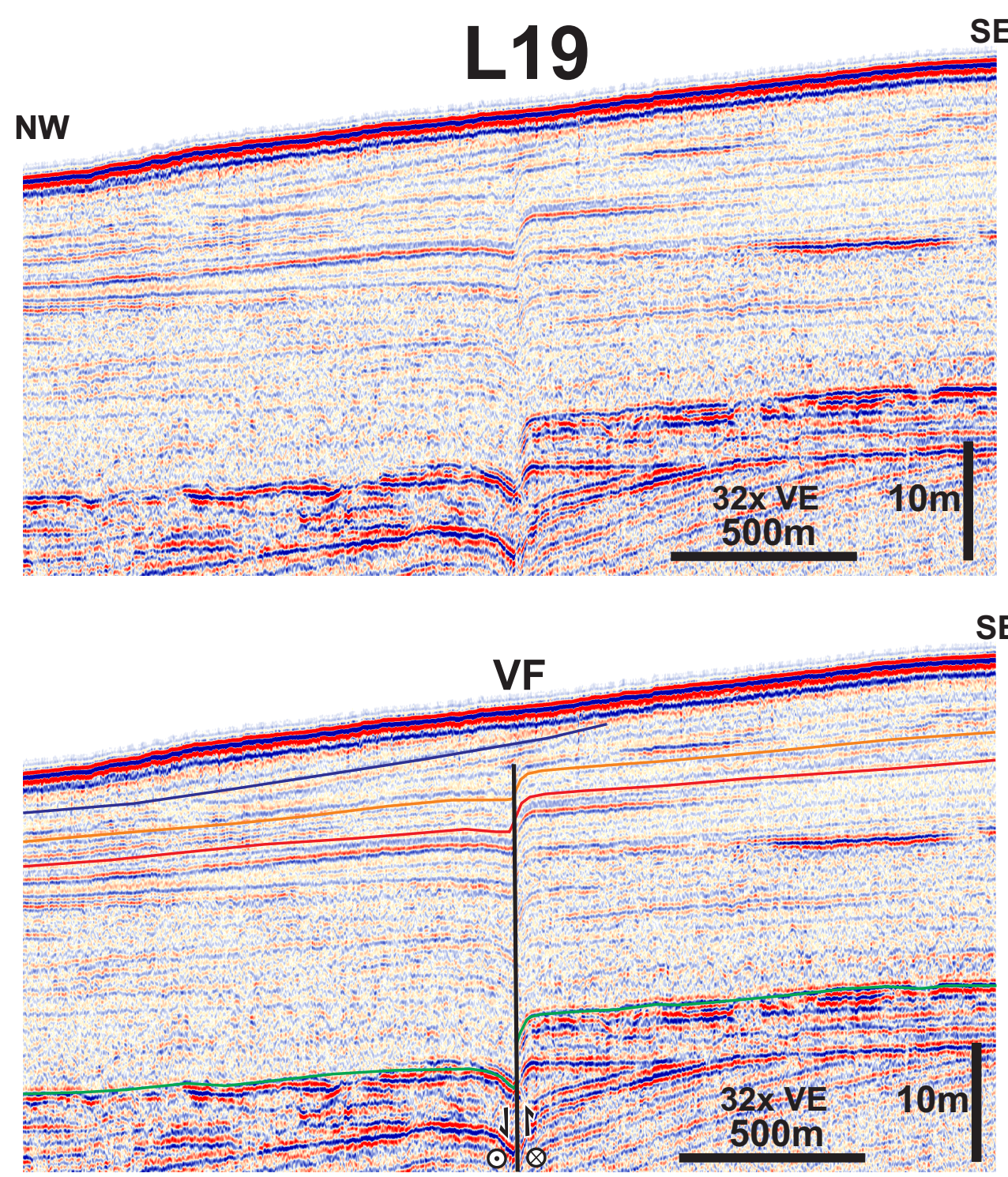

Figure E10a) Un-interpreted boomer seismic profile from line 19 (Fig. 1, Chapters 1 and 2). b) Interpreted boomer seismic profile from line 19 showing the Vernon Fault (VF). Splays of the coastal Awatere Fault have terminated to the west with only the Vernon Fault imaged. Postglacial sediments (above the green reflector) drape older Quaternary shelf sediments unconformably. The age of the green reflector is 20.1 $\pm 0.3 \mathrm{ka}$, the red reflector is $8.4 \pm 1.6 \mathrm{ka}$, and the orange reflector is $6.2 \pm 1.1 \mathrm{ka}$, and the blue reflector is $2.7 \pm 0.6 \mathrm{ka}$. 